\title{
Geneeskunde als wetenschap : wetenschapsidealen in de Nederlandse geneeskunde van 1840 tot 1970
}

Citation for published version (APA):

Heerding, C. (2000). Geneeskunde als wetenschap : wetenschapsidealen in de Nederlandse geneeskunde van 1840 tot 1970. [, Maastricht University]. Universiteit Maastricht. https://doi.org/10.26481/dis.20000324ch

Document status and date:

Published: 01/01/2000

DOI:

$10.26481 /$ dis.20000324ch

Document Version:

Publisher's PDF, also known as Version of record

\section{Please check the document version of this publication:}

- A submitted manuscript is the version of the article upon submission and before peer-review. There can be important differences between the submitted version and the official published version of record. People interested in the research are advised to contact the author for the final version of the publication, or visit the DOI to the publisher's website.

- The final author version and the galley proof are versions of the publication after peer review.

- The final published version features the final layout of the paper including the volume, issue and page numbers.

Link to publication

\footnotetext{
General rights rights.

- You may freely distribute the URL identifying the publication in the public portal. please follow below link for the End User Agreement:

www.umlib.nl/taverne-license

Take down policy

If you believe that this document breaches copyright please contact us at:

repository@maastrichtuniversity.nl

providing details and we will investigate your claim.
}

Copyright and moral rights for the publications made accessible in the public portal are retained by the authors and/or other copyright owners and it is a condition of accessing publications that users recognise and abide by the legal requirements associated with these

- Users may download and print one copy of any publication from the public portal for the purpose of private study or research.

- You may not further distribute the material or use it for any profit-making activity or commercial gain

If the publication is distributed under the terms of Article $25 \mathrm{fa}$ of the Dutch Copyright Act, indicated by the "Taverne" license above, 
GENEESKUNDE ALSWETENSCHAP 



\section{GENEESKUNDE ALS WETENSCHAP}

Wetenschapsidealen in de Nederlandse geneeskunde van 1840 tot 1970

\section{PROEFSCHRIF T}

ter verkrijging van de graad van doctor aan de Universiteit Maastricht, op gezag van de Rector Magnificus, Prof. dr. A.C. Nieuwenhuijzen Kruseman, volgens het besluit van het College van Decanen, in het openbaar te verdedigen op vrijdag 24 maart 2000 om 12.00 uur

door

Christine Heerding

geboren te Amsterdam 


\section{Promotores}

Prof. dr. R.H.J. ter Meulen

Prof. dr. W.J. van der Dussen (Open Universiteit Nederland)

C0-promotor

Dr. G. Verwey (Katholieke Universiteit Nijmegen)

Beoordelingscommissie

Prof. dr. C. Spreeuwenberg (voorzitter)

Prof. $\mathrm{dr}$. H. Beukers (Universiteit Leiden)

Prof. dr. E.S. Houwaert (Vrije Universiteit Amsterdam)

Prof. dr. R. Vos 


\section{Inhoud}

Voorwoord vii

1 Inleiding 1

1.1 Introductie 1

1.2 Onderzoek naar de geneeskunde als wetenschap, een eerste afbakening 2

1.3 Geschiedenis en geneeskunde 6

1.4 Filosofie en geneeskunde $\quad 9$

1.5 Paradigma en traditie in de geneeskunde 13

2 Geneeskunde als natuurwetenschap 21

2.1 De oriëntatie op de natuurwetenschappen in de geneeskunde 21

2.2 Het ziektebegrip in de natuurwetenschappelijke geneeskunde 37

2.3 Het klinisch oordeel in de natuurwetenschappelijke genees-

2.4 Johannes Nicolaas Ramaer (1817-1887) 56

2.5 Franciscus Cornelis Donders (1818-1889) 68

3 Geneeskunde als levenswetenschap $\quad 79$

3.1 Van mechanisme naar organisme 79

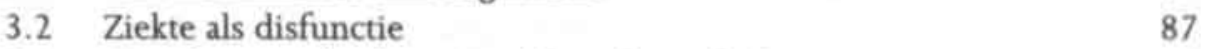

3.3 Causaliteit en finaliteit. Het klinisch oordeel op twee sporen 98

3.4 Cornelis Winkler (1855-1941) 106

3.5 Joannes Antonius James Barge (1884-1952) 116

4 Geneeskunde als menswetenschap $\quad 125$

4.1 Een antropologische geneeskunde 125

4.2 Het ziektebegrip in de antropologische geneeskunde.
De zieke mens

4.3 Het klinisch oordeel in de antropologische geneeskunde 144

4.4 Henricus Cornelius Rümke (1893-1967) 156

4.5 Andries Querido (*1912) 167 
$5 \quad$ Ter afronding

5.1 Terugblik en verantwoording 175

5.2 Geneeskunde als wetenschap $\quad 179$

5.3 Geneeskunde als praktische wetenschap $\quad 182$

5.4 Continuïteit en discontinuiteit 183

$\begin{array}{ll}\text { 5.5 Lessen voor het heden } & 186\end{array}$

$\begin{array}{lr}\text { Literatuur } & 189\end{array}$

$\begin{array}{ll}\text { Personenregister } & 215\end{array}$

$\begin{array}{ll}\text { Curriculum vitae } & 218\end{array}$ 


\section{Voorwoord}

Dit boek gaat over de verwetenschappelijking en verdere professionalisering van de geneeskunde. Het beschrijft de discussies over centrale begrippen als ziekte en klinisch oordeel sinds de geneeskunde zich in het tweede kwart van de negentiende eeuw als wetenschap heeft weten te vestigen, tot de jaren zeventig van de twintigste eeuw. In dit boek wordt historisch onderzoek gecombineerd met filosofische analyse. Vertrekpunt vormen enerzijds geschriften van medici over hun vak. Anderzijds is de filosofische notie dat wetenschap een belichaming vormt van het streven naar rationaliteit richtinggevend.

De inspiratie voor deze werkwijze ligt voor mij persoonlijk zo ver terug, dat ik hem zelf niet zou kunnen traceren. Geschiedenis heeft mij altijd geboeid. Dat geldt tevens voor een theoretische, reflectieve aanpak. Heel belangrijk was voor mij de wijsgerige scholing in Amsterdam, bij prof.dr. Th. de Boer. De mogelijkheid om in onderwijs bij andere faculteiten de door hem gewekte belangstelling voor de filosofische grondslagen van wetenschap te verdiepen, heeft zeker ook aan mijn vorming op dit gebied bijgedragen.

Deze studie vloeit in eerste instantie voort uit onderzoek verricht in de jaren tachtig aan de Katholieke Universiteit te Nijmegen bij de vakgroep Wijsgerige Antropologie van de Faculteit Wijsbegeerte. Het werd gefinancierd door de Faculteit Geneeskunde van de KUN. De aanzet tot dit project was gegeven door dr. H. ten Have, die de Faculteit Geneeskunde wist te overtuigen van het belang van reflectie op de wijsgerige vooronderstellingen van de geneeskunde. Toen bleek dat hij niet zelf het onderzoek zou uitvoeren, werd het project overgenomen door de vakgroep Wijsgerige Antropologie, een dynamische onderzoeksgroep waar prof. dr. C.E.M. Struyker Boudier aan het hoofd stond. Onder begeleiding van dr. G. Verwey, op wiens interesse en expertise ik altijd heb kunnen rekenen, zijn de fundamenten van het voorliggende werk gelegd. Goede herinneringen bewaar ik aan de gesprekken met de toenmalige beoogde promotores, prof. $\mathrm{dr}$. B.P.M. Schulte ( $\dagger 1991)$ en prof. dr. C.E.M. Struyker Boudier, die inmiddels het zwaartepunt van zijn werkzaamheden buiten de universiteit heeft gelegd.

Sindsdien is veel veranderd. Het onderzoek heb ik voortgezet als medewerker van Faculteit Cultuurwetenschappen van de Open Universiteit. Het werk bij de OU was (en is) telkens uitdagend. De Faculteit Cultuurwetenschappen, eerst nog productgroep Cultuurwetenschappen geheten, heeft in de jaren negentig in korte tijd en met betrekkelijk weinig menskracht een volledige WO-opleiding weten 
te realiseren, op basis van afstandsonderwijs. Daarenboven waren de contacten met de OU-studenten, die in het algemeen een brede kennis en ervaring hebben, zeker stimulerend. Maar er bestond vrijwel geen gelegenheid om het eigen onderzoek, dat niet direct was verbonden met onderwijs, voort te zetten. Ik ben de Faculteit dankbaar dat ik niettemin in het laatste stadium ruimte heb gekregen om het onderzoek af te ronden.

Velen hebben mij in de loop der tijd waardevolle suggesties en adviezen gegeven, waarvoor ik hier mijn erkentelijkheid wil betuigen. Prof. dr. W.J. van der Dussen is van grote betekenis geweest voor het welslagen van het project. Enerzijds leverde hij telkens constructieve aanwijzingen op grond van zijn specifieke deskundigheid op het gebied van zowel filosofisch als historisch onderzoek. Anderzijds waren zijn constante steun en vertrouwen van wezenlijk belang. Prof. dr. R.H.J, ter Meulen ben ik dankbaar voor zijn inzet in de laatste fase van het onderzoek. De combinatie van zijn kennis op het gebied van de filosofische aspecten van de hedendaagse geneeskunde, zijn historische belangstelling en een strak tijdpad zijn zeer vruchtbaar geweest bij de voltooiing. Door zijn betrokkenheid bij de totstandkoming van dit boek is tevens een verbinding gelegd met de aanvang van het onderzoek: ook hij maakte indertijd deel uit van de onderzoeksgroep te Nijmegen.

Een proefschrift komt niet tot stand zonder steun en stimulans van familie, vrienden en collegae. Ik zal hier geen opsomming geven, maar ik ben hen er bijzonder dankbaar voor. Dit boek draag ik op aan mijn vader, die door zijn vroegtijdig overlijden dit bewijs van de afronding van mijn academische opleiding niet meer in handen heeft kunnen nemen. 


\section{Inleiding}

\subsection{Introductie}

Als iemand zich ziek voelt, wordt hij of zij geacht medisch advies in te winnen. Deze stelregel geldt al eeuwen lang. In deze tijd, in Nederland, betekent de naleving ervan meestal dat hij of zij een beroep doet op de kennis en kunde van de huisarts en de specialist.

Tegenwoordig hebben diegenen die zich arts mogen noemen, huisartsen en medisch specialisten, aan een universiteit geneeskunde gestudeerd. $\mathrm{Zij}_{\mathrm{ij}}$ hebben bovendien voldaan aan door de overheid en de beroepsgroep opgestelde eisen. Geneeskunde maakte al eeuwen lang deel uit van het onderwijsaanbod van universiteiten. De tot rond 1850 bestaande variatie in bevoegdheden en opleidingen is sindsdien geüniformeerd en gestructureerd. Een academische opleiding in de geneeskunde vormt al vele jaren een noodzakelijke voorwaarde voor de uitoefening van de geneeskunde. Tezelfdertijd hebben de artsen als beroepsgroep zich weten te organiseren, in de nu 150 jaar bestaande (Koninklijke) Nederlandse Maatschappij tot bevordering der Geneeskunst. Op de universiteiten neemt de medische opleiding tegenwoordig een belangrijke plaats in, zowel door de studentenaantallen als op financieel gebied. In de huidige Nederlandse samenleving is de gezondheidszorg een belangrijke en kostbare verworvenheid. Het thema van deze studie wordt gevormd door de ontwikkelingen in de geneeskunde, sinds zij zich in de jaren veertig van de negentiende eeuw als "echte" wetenschap heeft geprofileerd. De hiermee verband houdende veranderingen hebben zich op velerlei terreinen afgespeeld, hetgeen wordt weerspiegeld in talloze studies over de geneeskunde die zich met deze ontwikkeling hebben beziggehouden.

De invalshoek van waaruit deze studie is geschreven steunt - qua methode - op ontwikkelingen in het overgangsgebied tussen filosofie en wetenschapsgeschiedenis. De geschiedenis van de geneeskunde wordt vanuit een filosofische vraagstelling bestudeerd. Het betreft een analyse en een reconstructie van historische concepten van de geneeskunde, en een beschrijving van de argumenten op grond waarvan zij destijds werden verdedigd, verworpen of verlaten. 


\subsection{Onderzoek naar de geneeskunde als wetenschap, een eerste afbakening}

Iedere wetenschap wordt, impliciet dan wel expliciet, gekenmerkt door bepaalde opvattingen over haar grondslagen en doelstellingen. Dat wil zeggen, er is sprake van een basale consensus over het object van onderzoek en de daarbij de geëigende methoden, alsmede de relevantie van het betreffende onderzoek.

De eigen tak van wetenschap wordt hierdoor gepositioneerd ten opzichte van andere. Vaak is ook duidelijk wie als expert en inspirerend voorbeeld geldt. Een dergelijk samenstel van filosofische noties, ideeën, idealen en opvattingen over de juiste methoden en vraagstellingen wordt aangeduid met de term "wetenschapsconcept" of "wetenschapsideaal". Wetenschapsidealen blijven evenwel niet constant, maar evolueren mee met de ontwikkeling van de wetenschap.

Medici zijn, of ze het zich realiseren of niet, vertrouwd met het geldende wetenschapsideaal. Ze zijn in hun opleiding getraind in bepaalde interpretatieschemata en verklaringswijzen, die een bepaalde geschiedenis hebben. Deze interpretaties fungeren binnen een geheel systeem van concepties en praktijken. Er is binnen zo'n wetenschapsideaal geen eenduidig onderscheid te treffen tussen een wetenschappelijk en een filosofisch denkniveau: mensbeelden interfereren met onderzoeksstrategieën en opvattingen over ziekte hebben zowel metafysische als empirische wortels. Zieken noch ziekten komt men zonder meer tegen als objectieve gegevenheden. Ziekten zijn gekoppeld aan mensen, aan verdriet en pijn. Medisch handelen vergt interpretatie, toegespitst op een bepaalde situatie van een bepaalde persoon. Het is iets dat aan de rand van het bed plaatsvindt. Desalniettemin omvat een bepaald wetenschapideaal criteria voor correct medisch handelen.

De legitimatie van het wetenschapsideaal binnen de geneeskunde is een zaak die niet alleen artsen aangaat. Ze berust op bredere opvattingen over wetenschap, over de mens en de natuur, over goed en gezond leven, over rechtvaardigheid, enzovoorts. Geneeskunde is derhalve geen losstaand gegeven. Geneeskunde is, zoals elke wetenschap, verworteld in het menselijk cultuurgoed en, als cultuurobject, toegankelijk voor cultuurwetenschappers, historici, filosofen.

In dit proefschrift staan drie opeenvolgende wetenschapsidealen in de geneeskunde centraal: de natuurwetenschappelijke, de levenswetenschappelijke en de antropologische. Het onderzoek begint met de ontwikkelingen rond 1840. Het geeft een beeld van de geneeskunde die zich net tot een zelfstandige wetenschap heeft weten te verheffen. Het wetenschappelijk karakter van de geneeskunde werd in deze periode fel verdedigd. Sindsdien is de geneeskunde erin geslaagd zich te handhaven als wetenschap, maar de discussies zijn niet verstomd. Nieuwe inzichten en idealen zijn naar voren gebracht, die leidden tot andere concepties van de geneeskunde. 
De opzet van deze studie is om de innerlijke samenhang en de legitimatie van verschillende opvattingen van geneeskunde naar voren te brengen. Vooronderstelling daarbij is dat elk van de beschreven concepties van geneeskunde een eigen consistentie vertoont, die evenwel niet louter als gegeven aantrefbaar is, maar ook gereconstrueerd kan en moet worden. Er worden in dit verband niet alleen afgeronde opinies gepresenteerd en gereconstrueerd, maar juist ook de opkomst en neergang daarvan. De bijbehorende onvrede, obstakels en doodlopende wegen worden beschreven, niet vanuit een (ver)oordelend standpunt, maar ten behoeve van inzicht in de geneeskunde als wetenschap en haar ontwikkeling. Ook in de huidige tijd is het debat niet gesloten. Maar de huidige controversen onttrekken zich aan de gekozen benadering. Uitgekristalliseerde wetenschapsidealen kunnen immers alleen retrospectief worden gereconstrueerd. Vandaar dat de beschreven periode eindigt rond 1970.

De opvattingen over de aard van de geneeskunde die hier worden geanalyseerd zijn die der artsen, zoals deze naar voren komen in vakbladen, congresbundels en handboeken. De bedoeling van deze studie is om het West-Europese denken over de geneeskunde, zoals dat in Nederland werd onderwezen en door Nederlandse artsen werd onderschreven, te onderzoeken. In de beschrijving van de verschillende opvattingen van de geneeskunde worden in verband hiermee vooraanstaande vertegenwoordigers daarvan aangehaald. Hun woorden vormen het bewijsmateriaal van de voorgestelde reconstructie. Uiteraard wordt hiermee niet van de vooronderstelling uitgegaan dat elke medicus in het betreffende tijdvak daadwerkelijk alle geschetste standpunten zou aanhangen. Binnen de beschreven wetenschapsconcepten waren - evenals nu - allerlei nuanceringen mogelijk. De hier geschetste visies op de geneeskunde vormden indertijd echter wel het op de voorgrond staande referentiekader, waaraan men zich conformeerde dan wel tegen afzette.

Elk hoofdstuk opent met een verkenning op conceptueel niveau, met een karakterisering van de geneeskunde in een bepaalde periode. De verschillende onderscheiden wetenschapsidealen worden via een bespreking van de toenmalige discussies gepresenteerd. Vervolgens wordt gepoogd de analyse te verhelderen door twee centrale concepten nader te onderzoeken: ziekte en het klinisch oordeel. Als min of meer constante aandachtspunten zijn deze immers wezenlijk voor wetenschapsidealen in de geneeskunde. Aan de hand van deze kernbegrippen kunnen de implicaties van de verschillende wetenschapsconcepten verder worden uitgediept.

Ziekte geldt van oudsher als een centraal begrip in de reflectie op de geneeskunde. De Duitse medisch historicus Rothschuh constateert dat denken over het bestaan, het wezen en de betekenis van ziekte altijd tot de onderwerpen heeft behoord waaromtrent de betrokkenen zich voorstellingen hebben gemaakt. "Die abendländische Medizin", aldus Rothschuh, "ist besonders reich an Versuchen, 
Krankheit und Heilung eine rationale Seite abzugewinnen, eine plausibele Erklärung zu finden und praktische Konsequenzen daraus zu ziehen" (Rothschuh, 1978, p. xiii). De uit deze pogingen resulterende alomvattende opvattingen van geneeskunde, waarbij de ervaring van de omgang met zieken wordt ingebed in een structuur van algemene principes en daaruit af te leiden conclusies, worden door Rothschuh betiteld als "Konzepte der Medizin". Binnen deze concepten treft men in meerdere of mindere mate aan: een leer over de mens, over ziekte en over genezing. Deze zijn - uiteraard - afhankelijk van de bestaande historische situatie en het heersende sociaal-culturele klimaat. Ze bouwen voort op bestaande religieuze, filosofische en wetenschappelijke opvattingen. De functie van dergelijke theoretische concepten voor de geneeskunde is, aldus Rothschuh, dat zij een legitimatie en rechtvaardiging verschaffen van de uitoefening ervan. Aan dergelijke meer algemene principes kan een ordening ontleend worden waarop het medisch handelen berust. Bij een bespreking van verschillende concepten van geneeskunde is het daarom noodzakelijk om aandacht te besteden aan de bijbehorende typen van ziekteconcept.

Rothschuh kiest in het geciteerde boek voor een systematische benadering van de verschillende door hem onderscheiden concepten, en niet voor een chronologische. Daarmee sluit hij aan bij een meer algemene trend in de geschiedenis van de geneeskunde. Voorbeelden van een dergelijke benadering zijn onder andere de analyses van het ziektebegrip door Riese en Kräupl Taylor (Riese, 1953; Kraüpl Taylor, 1979). Omdat in deze studie opeenvolgende wetenschapsidealen zullen worden besproken, staat hier juist wel de historische discussie over het ziektebegrip centraal.

In discussies rond de wetenschappelijke status van de geneeskunde richt de belangstelling zich veelal op het klinisch oordeel. Daarom vormt dit onderwerp een tweede centraal thema van deze studie. Het klinisch oordeel - waaronder worden verstaan de diagnose, de prognose en het therapievoorschrift - vervult zowel nu als in het verleden een sleutelrol, omdat daarin theorie en ervaring samenkomen. De kennis die een arts heeft vergaard tijdens zijn opleiding en die hij door middel van nascholing en het bijhouden van de relevante vakliteratuur vergroot en actualiseert, is niet alleen theoretisch van aard. Van oudsher is binnen de geneeskunde een belangrijke plaats ingeruimd voor ervaringskennis. De meeste afgestudeerden in de geneeskunde gaan niet een toekomst als wetenschappelijk onderzoeker tegemoet. Zij worden, zoals ook de bedoeling is van de opleiding, arts. Zij zullen hun opleiding toepassen in een specifieke context, aan het ziekbed.

Pellegrino en Thomasma stellen in hun filosofisch onderzoek naar de vooronderstellingen van de geneeskunde dat klinische interactie - "the healing relationship between physician and patient" - het onderscheidende kenmerk 
van deze discipline is, dat door alle takken van geneeskunde wordt gedeeld (vgl. Pellegrino \& Thomasma, 1981, p. 65). In de geneeskunde zijn wetenschappelijke verklaringen wel gewenst, maar zij vormen niet een doel op zich, ze staan in dienst van de uitoefening van de geneeskunde. Het voornaamste doel van de geneeskunde is het bieden van hulp aan zieken. Geneeskunde is gericht op de praktijk en wordt ook deels in de praktijk geleerd. "Somewhere along the road the students also have to be taught how to utilize all this theoretical knowledge for making the right diagnostic and therapeutic decisions, and this lesson is learnt at the bedside", aldus Wulff (Wulff, 1976, p. 1). Geneeskunde kan enerzijds worden vergeleken met andere wetenschappelijke opleidingen, bijvoorbeeld die in de biologie. Het is anderzijds evenwel kenmerkend voor de geneeskunde, dat de kennis wordt toegepast bij de beoordeling en behandeling van de concrete patiënt. Wil men de aanspraak op wetenschappelijkheid van de geneeskunde onderzoeken, dan is het dus van belang om na te gaan hoe er verantwoording wordt afgelegd voor de rationaliteit van het klinisch oordeel.

Ten slotte wordt in elk hoofdstuk aan de hand van de geschriften van een aantal vooraanstaande Nederlandse artsen uit de betreffende periode aangegeven hoe in hun werk de karakteristieke kenmerken van de geneeskunde uit hun tijd naar voren komen. Bij de keuze voor deze artsen, achtereenvolgens Johannes Nicolaas Ramaer (1817-1887), Franciscus Cornelis Donders (1818-1889), Cornelis Winkler (1855-1941), Joannes Antonius James Barge (1884-1952), Henricus Cornelius Rümke (1893-1967) en Andries Querido (*1912), speelden verschillende overwegingen een rol. Allereerst dienden ze onomstreden te boek te staan als voorbeeldig wetenschapsbeoefenaar en leermeester. Ze dienden verder in de beschreven periode te hebben gewerkt en te hebben gepubliceerd, ook over meer medisch theoretische onderwerpen. Zij zijn niet gekozen omdat zij de meest zuivere vertegenwoordiger zouden zijn van een bepaald concept van geneeskunde, maar omdat in hun werk het wetenschappelijk denken uit die tijd tot expressie komt. Hun opvattingen worden besproken omdat zij op maatgevende wijze gestalte gaven aan de geneeskunde als wetenschap. Ter wille van de breedte van het beschreven perspectief is telkens gekozen voor de combinatie van een psychiater en een medicus uit een meer somatische richting.

De studie eindigt met een korte bespreking van de resultaten. Wat is de opbrengst van een reconstructie van de verschillende wetenschapsidealen? Wat leren ons de debatten over het ziektebegrip en het klinisch oordeel? Hoe ga je om met denkbeelden van medici, die enerzijds tot voorbeeld strekken, maar anderzijds soms ook hopeloos verouderd zijn? Op deze vragen wordt gepoogd een antwoord te geven dat aansluit bij de gekozen invalshoek, een combinatie van historisch en filosofisch wetenschapsonderzoek. 


\subsection{Geschiedenis en geneeskunde}

Het onderzoek dat hier wordt gepresenteerd past enerzijds binnen de reflectie op de eigen identiteit van de geneeskunde en sluit anderzijds aan bij de belangstelling die ook buiten de geneeskunde bestaat voor haar geschiedenis. De geschiedenis van de geneeskunde bestrijkt een lange periode, tot ver voor het begin van onze jaartelling. Medisch-historici hebben gegevens aangedragen over de beoefening van de geneeskunde in Mesopotamië, India en Egypte en over de bijbelse geneeskunde. Uit de overgeleverde geschriften en inscripties valt af te lezen dat de theorievorming en opleiding in de geneeskunde al duizenden jaren serieus ter hand zijn genomen en dat de mogelijkheden en de grenzen van de medische beroepsuitoefening lang voor de Griekse Oudheid zijn beschreven.

In hun boek TheWestern Medical Tradition $800 \mathrm{BC}$ to $\mathrm{AD} 1800$ beschrijven verschillende leden van het "Wellcome Institute for the History of Medicine" in Londen de ontwikkelingen in de westerse geneeskunde tot het begin van de negentiende eeuw (Conrad e.a., 1995). Zij constateren dat uit de omgang met dergelijke gegevens een zekere dubbelzinnigheid blijkt in de verhouding van de medici ten opzichte van de geschiedenis van het eigen vakgebied. Men acht zich weliswaar de rechtmatige erfgenaam van Hippocrates, maar veelal wordt tegelijk een grote afstand geconstateerd ten opzichte van het gedachtegoed van degene die men zegt na te volgen. Enerzijds wordt er een continuiteit geconstrueerd, anderzijds wordt een grote kloof geconstateerd tussen de oude en de moderne opvattingen, methoden en geneeswijzen (vgl. Conrad e.a., 1995, p. 2).

In de geschiedenis van de geneeskunde wordt door velen gewezen op de breuk die zich in de eerste helft van de negentiende eeuw heeft voltrokken. Tot circa 1800 laat zich in de westerse geneeskunde een bepaalde traditie, een systeem van ideeën dat teruggaat tot de Griekse Oudheid, onderscheiden. Binnen deze periode grepen artsen terug op de kennis van hun reeds lang gestorven voorgangers als een bron van actuele informatie. Er bestond tot 1800 geen wezenlijke kloof tussen antieke en hedendaagse kennis (vgl. Conrad e.a., 1995, p. 3). Zolang er sprake was van een min of meer constant theoretisch kader kon men zodoende van de geschiedenis van de geneeskunde leren.

Deze ideeën raakten in de loop van de negentiende eeuw steeds meer op de achtergrond. De geneeskunde profileerde zich in deze periode als wetenschap en zette zich af tegen de eigen geschiedenis. Het nut van inzicht in de geschiedenis van de geneeskunde leek gering, als het voornamelijk om irrelevante misvattingen gaat en misschien enkele pogingen in de goede richting. Opvattingen van illustere voorgangers werden wel besproken, maar veelal in kritische zin. Het is niettemin opmerkelijk, zoals Conrad e.a. constateren, dat deze gedateerde westerse medische traditie toch ook in de hedendaagse geneeskunde een rol blijft spelen: "Yet, paradoxically, modern medicine continues to believe in and to 
shape the notion of tradition (...)" (Conrad e.a., 1995, p. 2). Beroemde voorgangers dienen niet meer als bron voor onmiddellijk toepasbare kennis, maar veeleer als voorbeeld, als 'historical icon'. Dat betekent dat er nog steeds een vorm van historisch besef geldt: "But there is equally a sense of the past, and of certain names, as forming the present of medicine, of a tradition that serves as a backbone to medical discovery and, still more, to medical practice" (Conrad e.a., 1995, p. 3). Er is dus zowel sprake van een grote afstand ten opzichte van de historische opvattingen als een zekere verwantschap. Het gaat dan vooral om een continuiteit in inspiratie en niet zozeer om inhoudelijke kennis. Men schaart zich ondanks de verschillen in een bepaalde, gedeelde traditie. Voor de periode na de breuk, de tweede helft van de negentiende en de twintigste eeuw, geldt dit besef van traditie en continuiteit in versterkte mate.

In Nederland schetste Van Lieburg onlangs het belang van een inzicht in de geschiedenis van de geneeskunde als volgt: "De dynamiek binnen de medische beroepsgroep is eeuwenoud. Waarover werd in de loop van de tijd geruzied? Als je de dynamiek begrijpt, krijg je meer grip op de situatie. Maar het biedt geen oplossing voor de problemen van nu, dat hoor je me niet zeggen. (...) Geschiedenis relativeert. Het zet gebeurtenissen op een tijdsas" (Van Lieburg. 1999, p. 44).

Sommigen zijn van mening dat inzicht in de geschiedenis van de geneeskunde nog meer teweeg kan brengen. Volgens Ten Have draagt kennis van de geschiedenis van de geneeskunde bij tot een relativering van de huidige inzichten en, naar hij hoopt, ook tot een heroriëntatie. Hij beschrijft hoe in de historische ontwikkeling van de geneeskunde twee fundamenteel verschillende benaderingen naar voren komen, die tegenwoordig worden onderscheiden als de biologische benadering, gericht op het individu, enerzijds, en de sociologische, gericht op de omgeving van de mens, anderzijds (Ten Have, 1983, p. 16). Ten Haves onderzoek spitst zich toe op twee theorieën van infectieziekten, die in zijn visie elk een representant zijn van één van beide benaderingen. Ten Have stelt dat in de geschiedenis van de geneeskunde nu eens de ene benadering de kop opsteekt en dan weer de andere. "Beide benaderingen, tenslotte, vormen een element van continuïteit in de discontinue ontwikkeling van de geneeskunde", zo stelt hij (ibid., p. 16). Met continuitteit bedoelt hij dat in elk van beide de filosofische stellingnamen gelijk blijven. Het gaat dan om mensbeelden, maatschappijvisies en opvattingen ten aanzien van het wezen van ziekte. De bedoeling van Ten Haves studie is dat de geneeskunde lering trekt uit haar geschiedenis in verband met haar huidige rol. In de geneeskunde van de laatste honderd jaar bezit de individueel gerichte biologische benadering een overwicht. Besef van de geschiedenis van de geneeskunde, waaruit blijkt dat beide benaderingen een rol hebben gespeeld, leidt, zo hoopt Ten Have, tot een relativering en een heroriëntering waarbij de noodzaak van een sociale benadering (weer) wordt erkend. 
In dit proefschrift wordt er niet van uitgegaan dat filosofische gezichtspunten constant blijven. De aandacht is gericht op verschuivingen binnen en tussen conceptuele kaders. Bovendien is het oogmerk van deze studie niet zozeer een relativering van de huidige geneeskunde aan de hand van historisch gefundeerde voorstellen tot verbetering. Het gaat mij met name om begrip van de traditie van de geneeskunde, die wordt gevormd door de opeenvolgende hierin gehanteerde concepten.

De door mij gekozen benadering van de geschiedenis van de geneeskunde hanteert ook een ander perspectief dan bijvoorbeeld Houwaert in diens proefschrift getiteld De hygiënisten. Artsen, staat en volksgezondheid in Nederland 1840-1890 (Houwaert, 1991). Hij bespreekt hierin de activiteiten en de gedachteontwikkeling van een groep Nederlandse geneeskundigen, de hygiënisten, in (met name) de tweede helft van de negentiende eeuw. Op deze wijze wordt de geschiedenis van sociaal-medisch onderzoek en openbare gezondheidszorg beschreven. Wetgeving, politieke ontwikkelingen, de organisatie van de medische stand, alsmede wetenschappelijke opvattingen en controversen, komen aan de orde. In deze studie wordt deels dezelfde periode besproken. Het essentiēle verschil met Houwaerts werk is evenwel daarin gelegen dat in de voorliggende studie geen historisch onderzoek naar de omstandigheden waarin bepaalde concepten tot stand zijn gekomen, wordt gepresenteerd. De formulering van de ideeễn zelf, de inhoud van de historische wetenschapsconcepten, vormt hier de focus van het onderzoek. Het gaat mij niet om inzicht in een ontstaansgeschiedenis, maar om inzicht in de traditie als een zich wijzigende constellatie van conceptuele kaders, gedragen door argumentatie en debat.

Sommigen schetsen vanuit een vertrouwen in de vooruitgang van de menselijke kennis de ontwikkelingen binnen de geneeskunde als een proces van groei. De geschiedenis volgt in deze visie een opgaande lijn, aangezien de concepten en in veel gevallen ook de praktijk, verondersteld worden steeds adequater te zijn. Met name in verband met de geneeskunde is deze visie nog wijdverbreid. De geschiedenis van de geneeskunde geeft ons dan vooral een beeld van hoe de weg tot nu toe is geweest, zonder een eigen waarde te hebben; het is louter voorgeschiedenis. De Nederlandse hoogleraar in de geschiedenis van de geneeskunde, Van Lieburg, waarschuwt in dit verband tegen de fout van het anachronistisch en positivistisch denken in de geschiedenis van de geneeskunde (Van Lieburg, 1987, p. 6). Een andere visie luidt dat er in de wetenschapsgeschiedenis alleen maar verandering en geen verbetering valt te bespeuren. Historisch onderzoek lijkt dan overbodig. Het dient alleen ter bevestiging van het feit dat er van een groei van kennis geen sprake is geweest.

Dit onderzoek gaat van geen van deze beide posities uit. Het gaat uit van de opvatting dat het verleden wordt bestudeerd vanuit het heden en vanuit de idee dat dit heden noch totaal contingent is, noch totaal vanuit het verleden is 
gedetermineerd. In de geschiedenis van de mens zijn bepaalde structuren van betekenis te onderkennen. Deze betekenisgeving vormt geen voorspelbaar proces. Voor een goed begrip van de huidige geneeskunde is een inzicht in haar historische ontwikkeling daarom van wezenlijk belang.

De vorm van wetenschapsgeschiedenis die hier wordt gepresenteerd, sluit aan bij de visie van de Duitse filosoof Apel. Zijn standpunt luidt dat: " (...) de historiografie van de wetenschap een paradigmatisch geval is van wat men 'geesteswetenschap' genoemd heeft (en misschien behoort te noemen) en dat binnen deze context eerder de 'rationele verklaring' in de zin van William Dray (d.i., begrijpen in de zin van Dilthey, Max Weber en Collingwood) dan de causale verklaring in de zin van, zeg Hempel, het relevante type verklaring zou kunnen zijn" (Apel, 1982, p. 5). Een dergelijke vorm van wetenschapsgeschiedenis is niet een empirische, descriptieve en verklarende wetenschap, die verhelderende feiten voorschotelt over het verleden. Het gaat hier om een combinatie van empirische en normatieve reconstructie, een "hermeneutische cirkel", die het mogelijk maakt om te leren van de geschiedenis (vgl. Apel, 1982, p. 12).

\subsection{Filosofie en geneeskunde}

Bij filosofisch georiënteerd onderzoek naar de geschiedenis van de geneeskunde is meerdere malen de aandacht gericht op de wijsgerige opvattingen van medici en ook op de wisselwerking tussen medische en wijsgerige opvattingen in een bepaald tijdvak. Voorbeelden hiervan zijn Kasanmoentalibs studie over de Duitse medicus V. von Weizsäcker en Verweys onderzoek naar de wijsgerige achtergronden van de psychiatrie aan het begin van de negentiende eeuw (Kasanmoentalib, 1989; Verwey, 1980). Er is ook aandacht besteed aan de kentheoretische stellingnamen in de geneeskunde. Met name het naturalisme en materialisme van de negentiende-eeuwse medici en fysiologen zijn nader onderzocht (vgl. o.a. Vidoni. 1991; De Moulin (red.), 1985; Cranefield (ed.) 1982; Gregory, 1977; Galaty, 1974).

Deze studie heeft niet de interactie tussen filosofie en geneeskunde in de bestudeerde periode tot onderwerp, maar de ontwikkeling van bepaalde visies binnen de geneeskunde zelf. Het onderzoek beweegt zich in het overgangsgebied tussen filosofie en wetenschapsgeschiedenis, omdat de historische ontwikkeling van de wetenschapsidealen binnen de geneeskunde centraal staan. De opzet is om een onderzoek te doen naar het West-Europese denken over de geneeskunde, zoals dat in Nederland werd onderwezen en door Nederlandse artsen werd onderschreven. Het onderzoek richt zich met name op de wetenschappelijke dimensie van de geneeskunde. Het betreft de medisch-theoretische uitgangspunten waarvan de medici elkaar in vakbladen trachten te overtuigen, alsmede 
de uitgangspunten waar studenten in worden opgeleid. Achterliggende mensbeelden worden als zodanig dus niet gethematiseerd. Centraal in deze studie staat derhalve niet de wijsgerige achtergrond, als wel de onderscheiden wetenschapsconcepten in hun hoedanigheid als paradigma. Een paradigma dat als voorbeeld fungeert en het kader aangeeft waarin het medisch wetenschappelijk handelen is ingebed en waardoor het wordt gelegitimeerd. In de bespreking van de wetenschapsconcepten worden overigens wel de hiermee verband houdende mensbeelden ter sprake gebracht. Dit geschiedt met het oog op hun rol in bepaalde argumentaties ten gunste van een bepaald wetenschapsconcept.

Van Lieburg maakt onderscheid tussen enerzijds medische geschiedenis, het medische aspect van het verleden, en anderzijds geschiedenis van de geneeskunde, waar het gaat om de historische ontwikkeling van de geneeskunde, in het bijzonder van de geneeskunde als "wetenschap". Deze studie valt binnen de tweede categorie, omdat medische concepten en theorieën centraal worden gesteld.

Van Lieburg is ook van mening - en daarin staat hij niet alleen - dat de medisch historicus bij voorkeur medisch geschoold moet zijn (Lieburg, 1987, pp. 4 e.v.). Zo heeft men, afgezien van praktische voordelen, zoals het spreken van de medische taal, toegang tot het begrippenapparaat en de medische noties, die in de actuele geneeskunde een rol spelen. Daardoor zijn bepaalde problemen gemakkelijker toegankelijk. Wat moet en wat kan een filosoof - zeker één die buiten de faculteit geneeskunde werkzaam is - dan met een onderwerp als de geschiedenis van de geneeskunde als wetenschap?

Deze vraag wordt overigens niet alleen in medische kringen gesteld. Het zijn immers de filosofen zelf geweest die de laatste decennia hun aspiraties en pretenties met betrekking tot de wetenschappen drastisch hebben bijgesteld. De idee dat men op historische en wijsgerige gronden de praktijk van de wetenschapsbeoefening zou kunnen verbeteren of het wetenschappelijk gehalte ervan zou kunnen verhogen, wordt tegenwoordig als ijdel en misplaatst beschouwd. Dergelijke normatieve beschouwingen worden veeleer aan de vakwetenschappers zelf overgelaten. Dit betekent evenwel niet dat een filosofische bemoeienis met een bepaalde vorm van wetenschapsbeoefening zinloos of overbodig zou zijn. In dit verband kan met name worden gewezen op de verschillende perspectieven die een vakwetenschapper en filosoof hanteren met betrekking tot de wetenschapsgeschiedenis. Verhelderend in dit verband is de visie van de Franse wetenschapsfilosoof Canguilhem, die bestaansrecht ziet voor een aparte, niet tot die van een vakwetenschapper te reduceren, wetenschapsfilosofische positie (vgl. Hertogh, 1986, pp. 120-121). De centrale wetenschapsfilosofische vraag is zijns inziens niet zozeer die van de rechtvaardiging van wetenschappelijke kennis, als wel die naar de betekenis van het verschijnsel (wetenschappelijke) kennis. Vanuit die optiek vormt de wetenschapsgeschiedenis 
het zwaartepunt van de epistemologie. Canguilhem constateert dat de filosoof en de vakwetenschapper met betrekking tot deze geschiedenis verschillende vragen stellen, die niet alleen samenhangen maar ook beide relevant zijn. Eigen aan de positie van de filosoof is de grotere distantie ten opzichte van de actuele wetenschappelijke noties, waarmee de wetenschapper zo vertrouwd is. Daardoor krijgt hij gemakkelijker zicht op andere theoretische opvattingen. De epistemologisch georiënteerde geschiedschrijving is, naar de mening van Canguilhem, een geschiedenis van wetenschappelijke probleemstellingen en tevens een geschiedenis die wetenschappelijke kennis op een hermeneutische wijze onderzoekt.

Onderwerp van onderzoek in deze studie is de traditie van de geneeskunde, zoals deze naar voren komt in de opeenvolgende wetenschapsidealen. In dergelijke concepten zijn filosofische ideeën nauw verweven met de wetenschapspraktijk. De analyse en reconstructie daarvan vergt een brede achtergrond. Wetenschapsfilosofisch en wetenschapshistorisch onderzoek sluiten in dit verband aan bij mijn filosofische opleiding en jarenlange ervaring op het vakgebied van de cultuurwetenschappen. Vanuit deze achtergrond benader ik de geschiedenis van de geneeskunde met een grotere distantie dan een arts. In de loop der jaren heb ik wel getracht mij de traditie eigen te maken waarin deze werkzaam is. Omdat ik mij nader heb verdiept in de geschiedenis van de geneeskunde zijn het betreffende begrippenapparaat en de medische noties mij meer nabij en vertrouwd geworden.

De geschiedenis van de geneeskunde kan vanuit diverse optieken worden bestudeerd. Een voorbeeld hiervan is de studie van Mol en Van Lieshout naar de naoorlogse veranderingen in het taalgebruik van twee takken van de Nederlandse geneeskunde, de huisartsgeneeskunde en de geestelijke gezondheidszorg, getiteld Ziek is het woord niet. Medicalisering, normalisering en de veranderende taal van huisartsgeneeskunde en geestelijke gezondheidszorg, 1945-1985 (Mol \& Van Lieshout, 1989). Hun analyse van de geschiedenis van het medisch taalgebruik is niet filosofisch in klassieke zin, niet louter een analyse van de termen waarin medici hun kennis vatten. Zij vragen ook aandacht voor de maatschappelijke betekenis en sociale werking van de geneeskunde, zodat de grens met de sociologie wordt overschreden. Anderzijds houden zij de sociologen en historici voor dat zij zich meer op de taal, en met name de niet constante betekenis van bepaalde begrippen, zouden moeten richten. De door Mol en Van Lieshout gepresenteerde theorievorming situeert zich aan gene zijde van de "traditionele spanning" tussen sociologie en filosofie.

Kernwoord van hun studie is, zoals uit de titel blijkt, het woord "ziek", of liever het debat over dit begrip. Methodisch gaan Mol en Van Lieshout ervan uit dat zij al lezende betekenissen kunnen reconstrueren. In dit verband zijn diverse teksten, afkomstig uit medische bladen zoals het Nederlands Tijdschrift voor Geneeskunde, 
over een periode van 40 jaar onderzocht. Er wordt hierbij van de vooronderstelling uitgegaan dat voor tijdgenoten de bestudeerde teksten betekenisvol waren (vgl. ibid., p. 85). Het gaat Mol en Van Lieshout niet om het achterhalen van de meningen en opinies die in die periode opgeld deden, maar om het vocabulaire waarin allerlei uiteenlopende meningen vervat zijn. Het achterhalen van betekenissen kan niet voor ieder woord afzonderlijk (vgl. ibid., p. 86). Er is evenmin sprake van totale vervangingen van complete taalsystemen. Er vinden veeleer voortdurend transformaties binnen het taalgebruik plaats van bepaalde elementen van de taal. Het is een proces waarin bepaalde interpretaties op de voorgrond komen. Deze winnen onder andere aan kracht als het mogelijk is om ze te illustreren (vgl. ibid., p. 87). Maar na verloop van tijd slinkt hun betekenis en volgt een herinterpretatie (vgl. ibid., pp. 135 e.v.). Mol en Van Lieshout zien de verschuivingen in de notie "ziek" als "verschil maken". Men lijkt het begrip "ziek" op een bepaalde betekenis te willen vastpinnen, maar dan ontglipt het weer. Het begrip "ziek" is rijker en wendbaarder dan in een definitie kan worden vastgelegd.

Mol en van Lieshout situeren hun onderzoek onder andere tegenover de normaliseringstheorie van Foucault en Canguilhems visie op wetenschapstheorie (vgl. ibid., pp. 66 e.v.). Canguilhem richt zich, aldus Mol en Van Lieshout, op de concepten waarin medische theorieën worden geformuleerd, dat wil zeggen, op de termen die een onderzoeksgebied ontsluiten. Deze benadering gaat altijd gepaard met het traceren van de historische opkomst van bepaalde concepten. Deze zijn geen termen die staan voor een ding. Ze maken deel uit van bepaalde netwerken en vertonen zo een samenhang met overige elementen van de taal waarin ze worden geformuleerd. Tot zover lijken Mol en van Lieshout het eens te zijn met Canguilhem. De wegen scheiden zich evenwel, omdat voor Canguilhem wezenlijk is dat wetenschap betrokken is op waarheid. In de woorden van Mol en van Lieshout: "Wetenschap, zegt Canguilhem, is niet zomaar een object, maar een vertoog met waarheidspretenties. Een epistemoloog ontkomt er volgens Canguilhem dan ook niet aan om over het onderwerp waarover hij schrijft een oordeel te hebben. (...) Canguilhem weet waar hij naar zoekt: van de waarheden van het heden is het de moeite waard de opkomst te traceren" (ibid., p. 68). Daarbij brengt Canguilhem, al oordelend, vergissingen aan het licht. Mol en Van Lieshout delen met Canguilhem en de normaliseringstheorie de opvatting dat er in de medische taal orde is vervat. Maar deze orde is niet eenvormig en zij verwerpen dan ook de gedachte dat zij te vinden zou zijn in waarheidsuitspraken. (vgl. ibid., pp. 256-257).

Mol en Van Lieshout achten dergelijke opvattingen van de geneeskunde te star, te statisch: "Door de geneeskunde in te voegen in een onbeweeglijk theoretisch raamwerk wijzen medicaliseringstheorie en normaliseringstheorie bij voorbaat de coôrdinaten aan waarbinnen variatie mogelijk is, maar die zelf stabiel blijven" (ibid., p. 262). Zij houden een pleidooi voor een andere benadering 
van de geneeskunde, waarin men kijkt naar de wijze waarop de geneeskunde ordent. Dat ordenen omvat een heterogene collectie activiteiten en laat ook veel open. Men gaat onder andere niet meer uit van het omvattende belang van "waarheidsuitspraken" (vgl. ibid., p. 264).

Verschil maken en verschil zichtbaar maken is ook het oogmerk van deze studie. In tegenstelling tot Mol en Van Lieshout staat de legitimatie van een aanspraak op geldigheid echter wel centraal. Mol en Van Lieshout hebben weliswaar gelijk als zij erop wijzen dat men, als men veranderingen onderzoekt, niet kan uitgaan van stabiele quasi ruimtelijke coördinaten, waardoor eerdere visies kunnen worden gesitueerd. De waarheden van het heden kunnen inderdaad niet worden ingezet om vergissingen op te sporen. Dat betekent echter niet dat daarom gedateerde waarheidsuitspraken zonder belang zouden zijn. Juist in dit soort uitspraken liggen immers de aanspraken op wetenschappelijkheid en rationaliteit besloten. Dat maakt ze bij uitstek van belang in een onderzoek dat is gericht op ontwikkelingen in de wetenschap.

In dit proefschrift zijn de verschillende concepten van ziekte meer dan variabelen, het gaat om steeds andere rationele constructies, die op grond van argumenten werden verdedigd en in de loop der tijd zijn verschoven. De waarheidsaanspraken die ermee waren verbonden, behoeven niet bij voorbaat als correct te worden beschouwd om ze hun speciale betekenis niet te laten verliezen. De opzet is de aantrekkingskracht van bepaalde concepten te tonen, alsmede de argumentatieve kracht die in hen schuilt. Juist door aandacht te schenken aan de waarheidspretenties, zonder deze kritiekloos over te nemen of als achterhaald te verwerpen, kan de rationaliteit van wetenschap als een praktische activiteit in beeld komen.

\subsection{Paradigma en traditie in de geneeskunde}

Het filosofische karakter van mijn onderzoek betreft de analyse van de legitimatie van het rationele, wetenschappelijke karakter van de geneeskunde. Deze analyse wordt in een historisch perspectief geplaatst. Het onderzoek strekt zich uit over de periode waarin de geneeskunde zich uitdrukkelijk heeft geprofileerd als wetenschap, dat wil zeggen sinds ongeveer 1840 . Als academische discipline werden door de geneeskunde bepaalde aanspraken op geldigheid verdedigd. Maar tegelijk werd de academische status ervan ter discussie gesteld. Herhaaldelijk werd de vraag opgeworpen of deze academische discipline wel een echte wetenschap was. En zo de geneeskunde al een wetenschap zou zijn, wat was hiervan dan de betekenis? Met welke andere wetenschappen was zij te vergelijken? Om welk type kennis gaat het in de geneeskunde? Zijn er andere wetenschappen die de geneeskunde eventueel als voorbeeld of ideaal zouden moeten worden voorgehouden? Deze thema's zijn in de afgelopen anderhalve eeuw juist 
in verband met de geneeskunde naar voren gebracht, omdat zij niet gemakkelijk is in te passen in een standaardbeeld van wetenschap, dat de rationaliteit garandeert. Op kritiek en twijfels werd overigens steeds weer een antwoord gevonden. Daarbij werden in de loop der jaren verschillende visies op de geneeskunde en wisselende paradigma's verdedigd. Voor een wetenschapstheoretisch en -historisch geinteresseerd filosoof zijn deze kwesties bij uitstek van belang. Ten aanzien van de begrippen "paradigma" en "paradigmawisseling" wordt hier aangesloten bij de opvattingen van Kuhn, zoals deze enkele jaren geleden door Derksen zijn beschreven (vgl. Derksen, 1997, pp. 205 e.v.). In de voorliggende analyse van de geneeskunde sinds 1840 worden een drietal elkaar in tijd opvolgende paradigma's beschreven. Paradigma's in Kuhniaanse zin bevatten bepaalde conceptuele schema's, een blauwdruk van het door de wetenschap te onderzoeken domein, methodologische regels en richtlijnen over wat als relevante vraag en adequaat antwoord wordt beschouwd. Daarenboven behoren bij een paradigma enkele maatgevende voorbeelden, die exemplarisch zijn voor de wijze waarop er binnen het paradigma verder onderzoek wordt verricht. Dergelijke paradigma's worden via allerlei kanalen, zoals tijdschriften en handboeken, maar ook via socialisatie en opleiding, verbreid. Kuhn gebruikte in 1962, in zijn boek The Structure of Scientific Revolutions de term "paradigma" in deze ruime betekenis (Kuhn, 1962). Enkele jaren later bracht hij in de tweede, uitgebreide druk van dit boek, een onderscheid aan tussen enerzijds de disciplinaire matrix en anderzijds het in filologische zin eigenlijke paradigma, het standaard voorbeeld (vgl. Kuhn, 1974 (1970)b, pp. 182 e.v. ; vgl. ook Kuhn, 1977 (1974), p. 307).

In de besproken periode uit de geschiedenis van de geneeskunde blijken er verschillende wetenschapsopvattingen te kunnen worden onderscheiden, die een tijdlang daadwerkelijk als paradigma functioneerden. Na verloop van tijd raakten ze echter ook weer op de achtergrond. Bepaalde vragen en problemen bleken niet meer zo bevredigend beantwoord te kunnen worden als men eertijds meende. Het betreft hierbij niet alleen een overmaat aan anomalieën in de beoefening van de wetenschap. In de geschiedenis van de geneeskunde blijken ook praktische twijfels, of ethische en metafysische vragen, te kunnen leiden tot de neergang van een paradigma.

Kuhn stelt dat voor de overgang van het ene paradigma naar het andere geen sluitende logische argumenten aan te voeren zijn. Paradigma's zijn in de ogen van Kuhn incommensurabel: ze kunnen niet in elkaars termen of neutrale variabelen worden vertaald (vgl. Kuhn, 1974 (1970)b, p. 200). Kuhn vergelijkt het overstappen van het ene paradigma naar het andere, met een bekering (Kuhn, 1974 (1970)a, p. 151). Dat wil overigens niet zeggen dat er geen goede redenen te geven zouden zijn (vgl. Kuhn, 1977 (1973), pp. 320 e.v). De ontwikkeling van de wetenschap is allerminst een irrationeel proces, aldus Kuhn. "Scientific behavior taken as a whole, is the best example we have of rationality" (Kuhn, 1971, p. 144). Bij de keuze voor of tegen een bepaald paradigma spelen vele 
factoren een rol. In deze studie wordt vanuit historisch perspectief verslag gedaan van deze afwegingen. In dit verband worden aspecten aan de orde gesteld als de worstelingen met oudere visies, de aantrekkingskracht van bepaalde zienswijzen, de hoop op vooruitgang en het geloof in de vruchtbaarheid van bepaalde benaderingswijzen. Deze zijn ook nu nog voor ons toegankelijk en de gehanteerde argumenten vertrouwd, hoewel de verschillende wetenschapconcepten als uitkomst van de betreffende debatten gedateerd zijn.

Bij de neergang van een bepaald denkkader treden nieuwe en betere conceptuele schema's op de voorgrond. Er worden nieuwe probleemdefinities, nieuwe oplossingsstrategieën, alsmede nieuwe theoretische en wijsgerige noties voorgesteld. Derksen toont aan dat vanuit een welbegrepen Kuhniaans perspectief een dergelijke wisseling in paradigma een reconstrueerbaar proces is (Derksen, 1997, pp. 210-211). Weliswaar zijn paradigma's incommensurabel, maar dat wil niet meer zeggen dan dat het ene niet volledig in termen van het andere kan worden beschreven. De overgang tussen paradigmata kan wel worden uitgelegd aan de hand van goede redenen. Deze redenen zijn evenwel geen wiskundige rekenregels - dan zou een theorieovergang immers een kwestie van berekening zijn en daar verzet Kuhn zich met zijn idee van incommensurabiliteit juist tegen. Het betreft hier oordelen op grond van gedeelde criteria zoals accuraatheid, consistentie, breedheid, eenvoud en vruchtbaarheid. Idiosyncratische factoren gerelateerd aan de individuele biografie en persoonlijkheid spelen echter ook een rol (vgl. Kuhn, 1977 (1973), pp. 329 e.v.). De toepassing van de gedeelde criteria leidt niet tot eenduidige conclusies. Ze functioneren niet als beslisregels, maar als waarden, normen of stelregels, die de keuze beïnvloeden (vgl. Kuhn, 1977 (1973), p. 331). "Values like accuracy, consistency, and scope may prove ambiguous in application, both individually and collectively; they may, that is, be an insufficient basis for a shared algorithm of choice. But they do specify a great deal: what each scientist must consider in reaching a decision, what he may and may not consider relevant, and what he can legitimately be required to report as the basis for the choice he has made." (Kuhn, 1977 (1973), p. 331). Deze waarden zijn, aldus Kuhn, in grote lijnen min of meer constant, al zijn ze in de loop der tijd op verschillende manieren tegen elkaar afgewogen.

Applicatie van normen veronderstelt praktische ervaring. "Though the experience of scientists provides no philosophical justification for the values they deploy (such justification would solve the problem of induction)", aldus Kuhn, "those values are in part learned from that experience, and they evolve with it" (Kuhn, 1977 (1973), p. 335). Om deze reden betrekken wij in deze stude niet de reflectie op de geneeskunde door filosofen, maar beperken wij ons tot de argumenten zoals deze zijn uitgewisseld in de vakbladen en handboeken van de medici zelf. De Amerikaanse wetenschapsfilosoof Bernstein heeft een methode geschetst voor de bestudering van dit voortdurende legitimatieproces. Hij situeert zijn benaderingswijze in de ontwikkeling van de wetenschapsfilosofie. Bernstein geeft 
aan dat daarin een verschuiving is opgetreden van logisch atomistische opvattingen naar een idee van historische en dynamische continuiteit. De eerste fase van deze ontwikkeling werd gekenmerkt door de pogingen om wetenschappelijke kennis te funderen in "de werkelijkheid" aan de hand van geisoleerde termen, bijvoorbeeld via ostensieve definities. In de tweede fase verschoof de aandacht bij de fundering van empirische kennis naar proposities, uitspraken, of descriptieve uitspraken. Men maakte hierbij gebruik van een betekeniscriterium, dat aangaf welke uitspraken wel of niet empirische betekenis hebben. In de daaropvolgende fase vormden conceptuele kaders het middelpunt van de epistemologische analysen. Een probleem daarbij was de vraag waarop deze conceptuele kaders betrekking hebben. De suggestie dat er een onderscheid zou zijn tussen hetgeen wordt gekend - onafhankelijk van de conceptuele kaders - en de verschillende wijzen waarop dat wordt opgevat, was niet onomstreden. Bernstein stelt in dit verband dat men in de wetenschapstheorie al te gemakkelijk is uitgegaan van het "dogma van een dualisme tussen schema en realiteit" (vgl. Bernstein. 1983, p. 77).

De hedendaagse wetenschapsfilosofie, de vierde fase, wordt aldus Bernstein, gekarakteriseerd door het besef dat, als men de rationaliteit van wetenschap wil onderzoeken - hét oogmerk van de wetenschapsfilosoof - men aandacht dient te schenken aan conflicterende theorieën, paradigma's, onderzoeksprogramma's en -tradities vanuit een historisch perspectief. Bij de bestudering van de historische ontwikkeling van conflicterende onderzoeksprogramma's - of wetenschapsidealen - komt naar voren dat er in de ontwikkeling van wetenschap ook sprake is van traditie. Deze traditie, of liever rivaliserende tradities, informeren de praktijk, maar worden daar ook door gemodificeerd. Behalve het essentiële belang van tradities voor wetenschappelijke ontwikkelingen, dient ook aandacht te worden besteed aan de aard, functie en dynamiek van onderzoeksgemeenschappen. Wetenschappelijke rationaliteit sluit immers altijd een notie van gemeenschap in.

Hoe kunnen conflicterende wetenschappelijke theorieên worden vergeleken? Bernstein onderschrijft Kuhns constatering dat rivaliserende paradigma's incommensurabel zijn. Ze kunnen niet puntsgewijs tegen elkaar worden afgemeten of op een uiteindelijk eenvormige methode worden afgewogen. Dat neemt niet weg, aldus Bernstein, en zijns inziens geldt dat ook voor ook Kuhn, dat vergelijken wel mogelijk is. Winst en verlies kunnen bijvoorbeeld worden gesignaleerd, evenals het feit dat de argumenten pro en contra van een rivaliserend paradigma niet sluitend zijn. Kortom, dergelijke vergelijkingen maken duidelijk welke typen en varianten van praktische rede betrokken zijn bij rationele afwegingen (vgl. ibid., p. 93). 
De erkenning van het feit dat er rivaliserende theorieèn bestaan, behoeft volgens Bernstein niet te leiden tot relativisme. De tegenstelling tussen objectivisme, waarin de geldigheid van de kennis wordt afgeleid uit het object, en relativisme wordt door Bernstein verworpen, of liever overschreden. De beklemmende keuze tussen ofwel over een vaste fundering van kennis beschikken, ofwel ten prooi zijn aan duistere krachten die ons omhullen met gekte en chaos - door Bernstein beschreven als de cartesiaanse angst - is niet onafwendbaar. Erkenning van incommensurabiliteit leidt niet noodzakelijk tot een afglijden naar relativisme: "The core of the incommensurability thesis, we have seen, is not closure and being encapsulated in self-contained frameworks but the openness of experience, language, and understanding. All of this contributes to the movement beyond objectivism and relativism and to liberating us from the Cartesian Anxiety" (ibid., p. 108).

Theoriekeuze is een zaak van praktische rationaliteit, aldus Bernstein, die zichzelf hiermee in het voetspoor van Kuhn plaatst. Het betreft hier geen berekening maar een oordeel, dat voorstellingsvermogen, interpretatie en het afwegen van alternatieven vergt. Dergelijke oordelen zijn open, maar niet ongefundeerd, ze berusten op redenen, die overigens in de loop van de wetenschappelijke ontwikkeling zelf ook aan verandering onderhevig zijn. In de loop der tijd is de kracht van de argumenten ten gunste van één der theorieën doorslaggevend voor de gemeenschap van betrokken wetenschappers. Popper suggereert dat men eigenlijk al bij voorbaat weet wat telt als een goed argument of kritiek als antwoord op een gissing. Zijn vooronderstelling hierbij is dat er heldere criteria zijn aan de hand waarvan kan worden onderscheiden onder welke voorwaarden een hypothese moet worden verworpen. We zouden bij voorbaat al de juiste standaarden voor kritiek kennen. Hier kan echter tegenin worden gebracht, aldus Bernstein, dat een wetenschapper in concrete situaties niet weet of hij met een onbelangrijk dwarsliggend voorbeeld te maken heeft, dan wel met een werkelijk falsifiërend bewijs. Het is in de wetenschap niet onmiddellijk inzichtelijk of bepaalde gegevens wel of niet als falsificatie moeten worden aangemerkt. Dat vergt wederom een oordeel. Poppers standaarden impliceren om deze reden interpretatie en dispuut (vgl. ibid., p. 71). De criteria waaraan wetenschappelijk onderzoek dient te voldoen, laten altijd verschillende interpretaties en toepassingen toe. In de loop van het wetenschappelijk onderzoek veranderen de gehanteerde standaarden en normen nu eenmaal. Bernstein concludeert dat het in de wetenschapsfilosofie niet alleen belangrijk is om de rol van traditie, zoals deze wordt belichaamd in onderzoeksprogramma's en onderzoekstradities, te begrijpen, maar ook hoe zulke tradities ontstaan, zich ontwikkelen, progressief en vruchtbaar zijn, en ook hoe ze degenereren (vgl. ibid., p. 25). 
In aansluiting hierop is Bernsteins rationaliteitsconcept gericht op praktische rationaliteit. Hij wijst in dit verband op de rol van keuzen, overleg en tegengestelde meningen. Rationaliteit berust niet op een onafhankelijke grondslag, maar op oordeelsvorming (vgl. ibid., p. 74). Wetenschappelijke argumentatie vereist rationele overtuigingskracht, die niet gelijkgesteld kan worden aan, of in het model gegoten kan worden van, deductieve bewijsvoering of inductieve generalisaties. Uiteraard wil dit niet zeggen dat een opeenstapeling van bewijs, data, redenen en argumenten niet doorslaggevend zou kunnen zijn binnen de wetenschappelijke gemeenschap. Maar de criteria hiervoor zijn niet voor eens en altijd vastgelegd of sacrosanct. In de loop der tijd kunnen er wijzigingen in optreden en ze kunnen ook worden verlaten.

Bernstein en Kuhn geven op de hier geschetste wijze een kader aan waarbinnen bepaalde begrippen kunnen worden gereconstrueerd en vergeleken. De conflicten tussen opeenvolgende wetenschapsconcepten, het opkomen van bepaalde normen en verdwijnen van andere, kan tegen deze achtergrond worden begrepen. In de bespreking van de historische opvattingen van geneeskunde, van ziekte en klinisch oordeel, zal worden gezocht naar de innerlijke samenhang en naar de legitimatie daarvan. De ontwikkeling van de medische wetenschap wordt dan opgevat als een discussie over rivaliserende concepten die op een bepaald moment de articulatie mogelijk maken van bepaalde inzichten en praktijken.

De rationaliteit van deze binnen de geneeskunde gehanteerde concepten is primair een praktische. In een wetenschapsideaal zijn weliswaar theoretische overwegingen ingesloten, maar niet als logisch noodzakelijke kenmerken ervan. Er zijn ten aanzien van centrale begrippen zoals "ziekte", bepaalde keuzen gemaakt, waardoor sommige aspecten meer op de voorgrond treden. Het is echter niet zo dat deze concepten een constant aantal vast omlijnde dimensies zouden omvatten, die in elke periode op variabele wijze worden opgevuld. In de interpretatie van het begrip "ziekte" komen veeleer telkens nieuwe patronen naar voren, die als meer adequaat ten opzichte van voorgaande worden gezien. In de beschreven argumentaties komen uiteenlopende kwesties aan de orde. Soms gaat het om een afweging van praktische aard, dan weer om de verwerping of omarming van metafysische opvattingen. Dat betekent evenwel niet dat latere concepten eerdere insluiten of deze juist verwerpen. De incommensurabiliteit verhindert dit. Maar het is wel mogelijk inzichtelijk te maken waaruit de voordelen of aantrekkingskracht van bepaalde concepten bestonden. Dit geldt ook voor de vraag op welke aspecten men in de discussie kritiek uitoefende. Bij de analyse hiervan is echter, zoals gezegd, geen sprake van een afmeten naar een vaste maatstaf of standaard van wetenschappelijke progressie. Evenmin leidt het tot een caleidoscoop van wisselende plaatjes van de geneeskunde. Er wordt wel 
degelijk een ontwikkeling binnen een wetenschapsgebied geschetst en geen loutere opeenvolging van opvattingen en ideeền, zonder enig logisch verband. Deze ontwikkeling is door Bernstein vergeleken met het begrip "traditie". Tradities hebben immers een vormende invloed op de praktijk: ze leven hierin voort en modificeren haar. Ze zijn door deze koppeling geen continu, noch een contingent gegeven.

De hierboven geschetste wijze van onderzoek impliceert ook de eerdergenoemde beperking van de te bestuderen periode. De opkomst en het verdwijnen van bepaalde concepten kunnen alleen retrospectief worden onderscheiden. De discussies over het wetenschappelijk karakter van de geneeskunde zijn niet verstomd. Maar een analyse van de hedendaagse controversen gaat het vermogen en de pretenties van de wetenschapsfilosoof te boven. Een reconstructie in termen van argumenten en goede redenen kan alleen achteraf geschieden. De filosoof kan geen rechtersrol vervullen in het actuele debat. Dit debat kan alleen zinvol door de betrokken wetenschappers zelf worden gevoerd. Een filosoof kan daaraan hoogstens een bijdrage leveren door de gehanteerde argumenten te expliciteren en de traditie van de discussie te schetsen. 



\section{Geneeskunde als natuurwetenschap}

\subsection{De oriëntatie op de natuurwetenschappen in de geneeskunde}

In de geschiedenis van de geneeskunde heeft zich halverwege de negentiende eeuw een ontwikkeling afgetekend, die tot op dit moment zijn sporen heeft nagelaten in de geneeskunde. In de jaren veertig vond binnen de geneeskunde een fundamentele wending tot de natuurwetenschap plaats. De periode die toen aanbrak, wordt aangeduid als het tijdperk van de natuurwetenschappelijk georiënteerde of, kortweg, natuurwetenschappelijke geneeskunde (vgl. o.a. Lichtenthaeler, 1974, pp. 530 e.v.; Rothschuh, 1975, p. 4; Rothschuh, 1978, pp. 428 e.v.).

Dit hoofdstuk zal pogen een beeld te schetsen van wat deze belangrijke verschuiving inhield. In de eerste drie paragrafen van dit hoofdstuk zal de natuurwetenschappelijke geneeskunde als wetenschapsconcept naar voren worden gebracht. Er wordt uiteengezet met welke specifieke opvattingen van ziekte en van het klinisch oordeel dit gepaard is gegaan. De invloed van de natuurwetenschappelijke oriëntatie op de Nederlandse geneeskunde zal vervolgens worden geillustreerd aan de hand van de bespreking van de ideeền van twee Nederlandse medici, die een belangrijk stempel hebben gedrukt op de opleiding en de beoefening van de geneeskunde in Nederland, Johannes Nicolaas Ramaer (18171887) en Franciscus Cornelis Donders (1818-1889).

In deze bespreking van de natuurwetenschappelijke geneeskunde wordt verwezen naar de ideeën van vooraanstaande personen uit de geneeskunde van de tweede helft van de negentiende eeuw, zoals C. Bernard (1813-1878), E. du BoisReymond (1816-1898), E. Brücke (1819-1892), W. Griesinger (1817-1868), H. (von) Helmholtz (1821-1894), J. Henle (1809-1885), H. Lotze (1817-1881), J. Moleschott (1822-1893), B. Naunyn (1839-1925), Th. Schwann (1810-1882), R. Virchow (1821-1902) en C.A.Wunderlich (1815-1877). De opvallende hoeveelheid Duitse geleerden laat zich verklaren uit het feit dat in de tweede helft van de negentiende eeuw de natuurwetenschappelijk gefundeerde Duitse geneeskunde wereldwijd als maatgevend werd beschouwd (vgl. o.a. Fischer-Homberger, 1977, p. 109).

Vanaf de jaren dertig van de negentiende eeuw raakte de beoefening van de fysiologie vooral in Duitsland in grote bloei. Ten opzichte van de rest van Europa, behalve wellicht Frankrijk, en de Verenigde Staten, was men ver vooruit in kennis en uitrusting. De verkregen onderzoeksresultaten werden verspreid via talrijke nieuw opgerichte tijdschriften, die overigens vaak slechts enkele jaren 
bleven bestaan. Rothschuh heeft in zijn History of Physiology beschreven welke reikwijdte de invloed van de twee toentertijd meest vooraanstaande onderzoekers, Joh. Müller (1801-1858) en C. Ludwig (1816-1895), en hun leerlingen tot in de twintigste eeuw heeft gehad (Rothschuh, 1973 (1953)). Analysen van de ontwikkelingen in de fysiologische publicaties in de tweede helft van de negentiende eeuw, wijzen eveneens op de centrale rol van de Duitse wetenschap (vgl. Bonah, 1995, p. 231). In de tweede helft van de negentiende eeuw had zelfs meer dan een derde van de vooraanstaande artsen in de Verenigde Staten, hun opleiding in Duitsland voltooid (Duffy, 1993, p. 168).

Nederlandse wetenschapsbeoefenaars oriēnteerden zich indertijd snel en energiek op deze ontwikkelingen in de geneeskunde (Vgl. bijv. Van Geuns, 1847; Van Geuns, 1857). In 1846 richtte Donders, wiens visie in het vervolg nader wordt beschreven, tezamen met I. van Deen (1805-1869) en Moleschott zelfs een Duitstalig wetenschappelijk tijdschrift op, de Holländische Beiträge zu den anatomischen und physiologischen Wissenschaften, dat overigens geen lang leven was beschoren. Het oogmerk van deze redacteuren was onder andere, dat de Nederlandse wetenschappelijke prestaties direct aan het hoogste wetenschappelijk forum zouden kunnen worden voorgelegd (vgl. van Deen, Donders, Moleschott 1848, p. V).

Er ontstond bij de opkomst van de natuurwetenschappelijke geneeskunde niet alleen een levendige uitwisseling en bespreking van wetenschappelijke resultaten. Er ontsponnen zich ook discussies over de geëigende methoden en concepten. Dat bracht met zich mee dat de wetenschapsopvatting zelf, impliciet aanwezig in de gepresenteerde voorbeelden, vooronderstellingen en idealen, zich op internationale schaal verbreidde. Het mechanistisch wetenschapsideaal ofwel het "mechanistisch vooroordeel", dat indertijd in Duitsland door veel vooraanstaande fysiologen werd onderschreven, kreeg daardoor grote invloed op het zelfbegrip van de geneeskunde (vgl. Verwey, 1980, p. 64).

Voordat het ziektebegrip en het klinisch oordeel binnen de natuurwetenschappelijke geneeskunde aan de orde kunnen worden gesteld, moeten er enkele karakteristieke kenmerken van de natuurwetenschappelijke oriëntatie worden beschreven, die een kader verschaffen voor de analyse van het ziektebegrip en het klinisch oordeel. Nagegaan wordt ten eerste welk speciaal karakter de genoemde oriëntatie van de geneeskunde op de natuurwetenschappen halverwege de vorige eeuw droeg. Waarom wordt juist de geneeskunde vanaf 1840 aangeduid met de term "natuurwetenschappelijk"? De natuurwetenschappen hadden immers ook in de voorafgaande eeuwen invloed uitgeoefend op de geneeskunde. In de zeventiende en achttiende eeuw werden veelvuldig methoden en bevindingen uit de natuurwetenschappen toegepast binnen het geneeskundig onderzoek. Stromingen als de iatro-fysica en de iatro-chemie getuigen van de toenmalige wederzijdse beinvloeding en bevruchting. In zijn boek Konzepte der Medizin in Vergangenheit und Gegenwart geeft Rothschuh een uitvoerig beeld van de 
toepassing van de natuurwetenschappen in de geneeskunde (Rothschuh, 1978. pp. 228 e.v.). In de toenadering tussen natuurwetenschappen en geneeskunde is evenwel rond het midden van de negentiende eeuw een principiële stap gezet. De natuurwetenschappen werden niet langer beschouwd als een vruchtbaar voorbeeld en als een rijke schatkamer van gegevens en methoden waaruit de geneeskunde kan putten. De geneeskunde werd zelf tot een natuurwetenschap verklaard. Na de eerdere "op zich zelven staande strooptogten" op het gebied van de natuurwetenschappen, wordt dan de medische wetenschap in haar geheel gezien als "natuurleer" (vgl. Moleschott, 1989 (1856), p. 67).

Rond 1850 slaagde de geneeskunde in haar pogingen om aansluiting te vinden bij de natuurwetenschappen. Ze wist zich te profileren als een (toegepaste) natuurwetenschap (vgl. o.a. Ackerknecht, 1959 (1955), p. 116). Dit feit had ook consequenties voor haar wetenschappelijke status. Zodra de geneeskunde werd erkend als één der natuurwetenschappen, en zolang haar beoefenaren zich zouden houden aan de methodologische regels van de natuurwetenschap, zou het wetenschappelijke gehalte van de geneeskunde gewaarborgd blijven. Uit deze inlijving van de geneeskunde bij de natuurwetenschappen blijkt tegelijkertijd hoezeer de exclusieve aanspraak op rationaliteit en wetenschappelijkheid van de natuurwetenschappen zich in de tweede helft van de negentiende eeuw had uitgebreid (vgl. Verwey, 1980, pp. 57 e.v.; Cassirer, 1973, p. 94).

Eén der belangrijkste uitgangspunten van de aanhangers van de natuurwetenschappelijke geneeskunde was de overtuiging dat geneeskunde zich dient te baseren op de ervaring. Wunderlich beschreef het in zijn in 1858 verschenen en in 1861 in het Nederlands vertaalde, Geschiedenis der geneeskunde, als volgt: "De geneeskunde van den tegenwoordigen tijd kent hare taak en hare pligten, als een deel uitmakende van de onmetelijke en verhevene wetenschap der natuur. Het is haar duidelijk geworden, dat hare grondslagen niets anders dan de feiten zijn, en dat de kennis der feiten, voor zoover die mogelijk is, slechts in de verbinding der feiten zelve met elkander te vinden is. Maar zij weet ook, dat waarachtige feiten slechts door een gestreng vasthouden aan de methode van het onderzoek en door zich steeds de bronnen van dwaling voor den geest te stellen verkregen worden. Men beschouwt den geest niet meer als aan banden gelegd, omdat hij gedwongen wordt aan de methoden te arbeiden en zijne invallen aan het scherpe toezigt eener geordende logica te onderwerpen. Men denkt er niet meer aan om aan de natuur een stelsel op te dringen, maar men streeft er naar om het zijn en het geschieden, gelijk het is en waar het is, in de meest mogelijke zuiverheid op te sporen" (Wunderlich 1861 (1858), p. 291).

Op zichzelf was de nadruk op het belang van de ervaring in de geneeskunde van rond 1840 niets nieuws. In de achttiende eeuw werd ervaring misschien niet zo belangrijk geacht als binnen de natuurwetenschappelijke geneeskunde, maar ervaringskennis werd bepaald niet als irrelevant terzijde geschoven. Ook in de 
geneeskunde van de eerste helft van de negentiende eeuw was de ervaring als bron van kennis geenszins achteruitgegaan in belangstelling en waardering. Verschillende invloedrijke stromingen, zoals de Weense School van J. Skoda (18051881) en C. Rokitansky (1808-1878) en de Parijse klinische School van onder anderen F. X. Bichat (1771-1802), bepleitten met klem een zorgvuldige, objectieve, wetenschappelijk verantwoorde waarneming, zowel aan het ziekbed als in de pathologische anatomie. Er waren wel belangrijke punten van verschil tussen de Hippocratische opvatting van klinische ervaring in de achttiende eeuw, onder andere bij $\mathrm{H}$. Boerhaave (1668-1738), en de klinische ervaring in de eerste decennia van de negentiende eeuw. In de negentiende eeuw zagen de artsen veel grotere aantallen patiênten dan voorheen. De methode van onderzoek bestond niet meer uit het passief gadeslaan van de patient, doch uit het actief onderzoeken met behulp van nieuwe fysische diagnostische methoden. Ten slotte werden de waargenomen symptomen expliciet verbonden met bij sectie gevonden gegevens (vgl. Ackerknecht, 1959 (1955), pp. 116-117).

Toch werd het standpunt dat de waarneming en ervaring van fundamenteel belang zijn door de voorstanders van de natuurwetenschappelijke geneeskunde met kracht als een vernieuwing naar voren gebracht. Het opmerkelijke van deze visie was de combinatie van het pleidooi voor objectiverende en kwantificerende onderzoeksmethoden, zoals ook al eerder werd gehouden, met een gerichtheid op het experiment (vgl. Rothschuh, 1978, p. 432). De Nederlandse hoogleraar J. van Geuns (1808-1880) formuleerde het in zijn Inwijdingsrede over de geneeskunde als eene zelfstandige natuurwetenschap van 1847 als volgt: "Niet het doode begrip, neen de ervaring door proeven en waarnemingen verkregen moet ons de deur der waarheid ontsluiten; inductie en analogie moeten de nasporing geleiden" (Van Geuns, 1847, p. 19). De uit het wetenschappelijk onderzoek verkregen feiten werden vanuit bepaalde hypothesen geordend, in het experiment werden veronderstelde samenhangen getoetst (vgl. o.a. Woodward \& Pester, 1994, p. 168). Observeren, classificeren en systematiseren was niet meer voldoende. Er moesten hypothesen worden geformuleerd, die getoetst konden worden (vgl.Virchow, 1847, p. 17: Rather, 1958, p. 13).

Op 23 december 1854 hield de Franse onderzoeker Bernard zijn studenten op college voor dat de geneeskunde en de fysiologie "sciences d'observation et d'expérimentation" zijn. De beoefenaar van deze wetenschappen dient volgens Bernard als volgt te werk te gaan: " 1 . Établir les faits ou les phénomènes par l'observation et l'expérimentation jusqu'à ce qu' il ait épuisé ce que ces moyens peuvent lui fournir; 2. s'élever par induction de ces faits ou phénomènes à leurs rapports généraux qu'il appelle des lois; 3 . enfin partir de ces lois pour aller, par un raisonnement logique de déduction, à la recherche d'autres faits particuliers qui puissent à leur tour être compris dans la loi générale" (Bernard, 1855, p. 6). 
Net als in de andere wetenschappen worden in de geneeskunde feiten en theorieên op logisch coherente wijze aan elkaar gerelateerd, aldus Bernard. Observatie en experiment verschaffen de feiten, waarop deze wetenschappen steunen. Maar deze feiten bestaan niet op zichzelf, ze worden onmiddellijk door de formulering van wetten en theorieën met elkaar in verband gebracht. Uit die theorieēn worden voorspellingen, hypothesen afgeleid, die vervolgens in het experiment aan de ervaring worden getoetst.

De Duitse hoogleraar in de interne geneeskunde Naunyn beschreef in zijn oratie te Dorpat het experimentele karakter van de natuurwetenschappelijke geneeskunde zeer bondig als volgt: "Die Medizin wird eine Wissenschaft sein, oder sie wird nicht sein. (...) Die Medizin muß Naturwissenschaft sein, oder doch wenigstens auf naturwissenschaftlichen Boden stehen, und die Methode ist das Experiment" (Naunyn, 1869). In 1870 beschreef Bernard de evolutie van de wetenschappen in drie stadia. Het eerste is het prewetenschappelijke of empirische stadium, het tweede is het stadium van de observerende wetenschap en het derde stadium is dat van de experimentele wetenschap. Door haar complexiteit loopt de geneeskunde wat achter in deze ontwikkeling, aldus Bernard. Maar ze is op haar beurt nu toch in het experimentele stadium geraakt (vgl. Bernard, 1872. p. 566).

Het concept van ervaring dat de natuurwetenschappelijk georiënteerde geneeskundigen voor ogen stond, was een vorm van experimenteel gestuurde ervaring. Het verzamelen van empirische gegevens werd gecombineerd met theorievorming, die vervolgens via proeven werd gecontroleerd. Observatie, hypothese én experiment zijn kenmerkend voor de werkwijze binnen de natuurwetenschappelijke geneeskunde.

De nadruk op het experiment en op kwantitatief geformuleerde resultaten bracht met zich mee dat er zowel in de kliniek als in het laboratorium, ten behoeve van experiment en diagnostiek, in toenemende mate gebruik werd gemaakt van onderzoeksapparatuur. In de periode waarin de natuurwetenschappelijke geneeskunde tot bloei kwam, zijn er op het gebied van de biomedische onderzoekstechniek vele vindingen gedaan. Daarnaast hebben de ontwikkelingen op het gebied van de chemie en de fysica bijgedragen tot de mogelijkheid van een op natuurwetenschappelijke leest geschoeide geneeskunde. Ten tijde van de natuurwetenschappelijke oriëntatie in de geneeskunde raakten laboratorium en kliniek zodoende met elkaar verstrengeld (vgl. o.a. Lichtenthaeler, 1974, p. 534).

De natuurwetenschappelijke geneeskunde steunde sterk op de fysiologie. De bekende Duitse voorvechter van de natuurwetenschappelijke geneeskunde Virchow, schreef in 1847 in een programmatische verhandeling over de uitgangspunten van een wetenschappelijke geneeskunde expliciet dat haar fundament wordt gevormd door de fysiologie (Virchow, 1847, p. 4). Bernard herhaalde keer op keer dat een wetenschappelijke, dat wil zeggen experimentele, 
geneeskunde zonder fysiologie onmogelijk was. In elke periode van haar ontplooing als wetenschap is er in de geneeskunde weliswaar gebruikgemaakt van fysiologische kennis, zo stelde Bernard, maar de toepassing van deze kennis ging steeds gepaard met het incorporeren daarvan binnen de bestaande theoretische systemen. Deze systemen waren zelf in één geheel opgetrokken vanuit één bepaalde zienswijze. In de huidige tijd is de relatie van de geneeskunde met de fysiologie echter wezenlijk anders, aldus Bernard. Nu de geneeskunde de pretentie heeft zelf een (natuur)wetenschap te zijn, wordt volgens hem duidelijk dat de experimentele fysiologie de basis is van het medische wetenschappelijk bouwwerk: "C'est qu' au fond, dans la médecine, il n'y a qu'une seule science: la science de la vie, ou la physiologie" (Bernard, 1872, p. 568; vgL ook: Bernard, 1855, p. 23; Bernard, 1865, p. 7).

De natuurwetenschappelijke geneeskunde heeft bij uitstek kennis willen verwerven omtrent veranderingsprocessen. Vandaar de wending tot de fysiologie, waar het functioneren van het organisme in zijn samenhang en in de tijd wordt bestudeerd. De pathologische anatomie, voordien beschouwd als het fundament der geneeskunde, boette aan belangrijkheid in. De kritiek luidde dat de anatomie, hoewel ze de benodigde empirische feitenkennis verschaft, tekortschiet omdat het perspectief van ontwikkeling erin ontbreekt. Descriptie en classificatie alleen werden onvoldoende geacht. "Die eigentliche Wissenschaft hebt erst mit der Geschichte der Körper an; sie forscht nach dem Mechanismus und den Bedingungen ihres Entstehens und Entwickelns, nach den zeitlichen und ursächlichen Beziehungen zwischen den Körpern; sie hat es weniger mit den Körpern selbst, als mit den Vorgāngen an den Körpern, mit der Erscheinung und Bewegung zu thun" (Virchow, 1847, p. 11). Het bepleite empirisch onderzoek, de toetsing van hypothesen, is gericht op de bestudering en verklaring van zich in de tijd voltrekkende processen. De anatomie bleef in de natuurwetenschappelijke geneeskunde weliswaar een belangrijke rol vervullen, maar werd ondergeschikt geacht aan de fysiologie. Fysiologisch experimenteren ging voor, terwijl de anatomie achteraf een bijdrage kon leveren aan de verklaring van de daarbij ontdekte fenomenen (vgl. Bernard, 1856, p. 17).

Het afnemend prestige van de anatomie hangt ook samen met de uitdrukkelijke wens van de natuurwetenschappelijke geneeskunde om zieken op verantwoorde wijze te helpen en liefst te genezen. Kennis van vitale processen stelt een arts namelijk niet alleen in staat om terugkijkend een verklaring te geven van een bepaalde toestand. Door deze kennis is het in principe ook mogelijk om, vooruitziend, bepaalde wetenschappelijk gefundeerde voorspellingen te doen en om met succes te kunnen ingrijpen in ziekteprocessen. Deze mogelijkheden waren voor de aanhangers van de natuurwetenschappelijke geneeskunde van wezenlijk belang. $\mathrm{Zij}$ beklemtoonden veelvuldig dat de geneeskunde ook een praktische taak heeft (vgl. o.a. Virchow, 1847, pp. 7-8; Helmholtz, 1903 (1877), p. 183; 
Bernard, 1865 , p. 5). In paragraaf 2.3 zal dit aspect van de natuurwetenschappelijke geneeskunde nader aan de orde worden gesteld.

Met de herformulering van de geneeskunde als natuurwetenschap werd niet alleen een bepaalde onderzoeksmethode bepleit. Het onderzoeksobject van de geneeskunde, het wel en wee van de zieke mens, werd eveneens zodanig omschreven dat het zich liet voegen naar een natuurwetenschappelijke benadering. In de natuurwetenschappelijke geneeskunde zag men de mens als een natuurlijk fenomeen: men beschouwde de patiënt als onderdeel van de dankzij de wetenschap te beheersen natuur.

In de jaren veertig ontstond onder de jongere garde van (fysiologische, geneeskundige en medisch-filosofische) auteurs die een hoofdrol zouden spelen in de vestiging van het concept van een natuurwetenschappelijke geneeskunde Schwann, Henle, Virchow, Griesinger, Wunderlich, Brücke, Ludwig, Helmholtz, Du Bois-Reymond - bovendien consensus omtrent de uitgangspunten bij de wetenschappelijke bestudering van de levende natuur. Eensgezind was men van mening dat krachten in de levende natuur niet principieel verschillen van die in de anorganische natuur. Men was ervan overtuigd dat de levende en de dode natuur op dezelfde wijze - volgens dezelfde natuurwetten - functioneren, en dus ook met behulp van dezelfde vormen van wetenschap, te weten fysica en chemie, te beschrijven zijn.

Virchow omschreef dit uitgangspunt in 1858 als volgt: "Es ist ganz gleichgültig. ob man das organische oder das anorganische Schaffen betrachtet. (...) Ueberall nur mechanisches Geschehen in ununterbrochener Nothwendigkeit der Verursachung und Bewirkung. Der Plan ist in den Körpern, das Ideale im Realen, die Kraft im Stoff" (Virchow, 1971 (1858), p. 26). Enkele bladzijden daarboven had hij gesteld: "So besonders und eigenthümlich, so sehr innerlich daher auch das Leben ist, so wenig ist es der Herrschaft der chemischen und physikalischen Gesetzen entzogen. (...) Jede Besonderheit des Lebens findet ihre Erklärung in besonderen Einrichtungen anatomischer oder chemischer Art, (...) Vergeblich bemüht man sich, zwischen Leben und Mechanik einen Gegensatz zu finden; alle Erfahrung führt zu dem gleichen Schlusse, daß das Leben eine besondere Art der Bewegung bestimmter Stoffe sei, welche mit innerer Nothwendigkeit auf die ihnen zukommenden Erregungen, auf einen 'Ansto B' hin in Thätigkeit treten" (ibid., pp. 14-15). Kortom, als men fenomenen in de levende natuur op correcte wijze wetenschappelijk wil onderzoeken, dienden deze volgens Virchow te worden gereduceerd tot fenomenen, die in fysische en chemische termen te verklaren zijn.

Deze beoogde reductie staat in nauw verband met de afwijzing van het vitalisme in de natuurwetenschappelijke geneeskunde. Onder vitalisme wordt in het algemeen de opvatting verstaan dat levende organismen krachten of eigenschappen bezitten, dan wel dat er bepaalde machten of principes in werkzaam zijn, die 
fysisch noch chemisch van aard zijn. Tevens houdt het de overtuiging in dat elke verklaring van de karakteristieke eigenschappen van levende organismen die niet verwijst naar dergelijke krachten, eigenschappen, machten of principes incompleet is (vgl. Benton, 1974, p. 18).

In het begin van de negentiende eeuw gold het vitalisme binnen de wetenschappelijke geneeskunde als een acceptabele zienswijze. Verschillende bekende Franse fysiologen uit die periode, zoals F. Magendie (1783-1855) en de eerder genoemde Bichat, huldigden een bepaalde variant van vitalisme (vgl. Temkin, 1946. pp. 322 e.v.; Rothschuh, 1968 b, pp. 213 e.v.). Het menselijk lichaam kon in hun visie niet louter als een machine worden beschouwd. De wetten van de dode natuur achtten zij onvoldoende om alle manifestaties van het leven te verklaren. In dezelfde periode onderschreven ook in Duitsland talrijke bekende onderzoekers, onder wie de eerder genoemde Joh. Müller en E. H. Weber (1795-1878), vitalistische standpunten (vgl. o.a. Joh. Müller, 1833, pp. 27-28; Lenoir, 1982; Woodward \& Pester, 1994, p. 164).

De mogelijkheid van levenskracht als verklarend principe in de wetenschap van de levende natuur werd echter door de aanhangers van de natuurwetenschappelijke geneeskunde volstrekt verworpen. Ook de met het vitalisme verbonden teleologische beschouwingswijze, dat wil zeggen het denken in eind- of doeloorzaken, wezen zij met kracht van de hand. Dergelijke opvattingen werden als verklarend principe radicaal buiten de wetenschap geplaatst en verbannen naar het terrein van de levensbeschouwing.

In zijn colleges en geschriften heeft Bernard zich regelmatig verzet tegen het vitalisme van zijn voorgangers. Hij bekritiseerde met name Bichat, die het principe van de levenskracht een plaats binnen de wetenschap had willen geven. Bernard erkende dat levende wezens in vergelijking met levenloze objecten worden gekenmerkt door "quelque chose de vital", maar dat is niet meer dan "la cause première des manifestations vitales", en eerste oorzaken behoren volgens hem als studieobject buiten de wetenschap gelaten te worden (vgl. Bernard, 1872, p. 562). Noties als de levenskracht en het leven behoren zijns inziens tot de wereld van de metafysica (vgl. Bernard, 1966 (1878), p. 54). Pogingen om twee typen wetenschap te creëren, één van de dode natuur en één van de levende natuur, waarbij ervan wordt uitgegaan dat in de wetenschappen van de levende natuur geen vaste wetten en welomschreven determinanten zijn, moeten, aldus Bernard, als een vorm van misbruik van de term "wetenschap" worden beschouwd en lopen zelfs uit op een ontkenning van wetenschap als zodanig (vgl. ook Bernard, 1890, pp. 179 e.v.). De vitalistische doctrine berust volgens hem niet alleen op verkeerde hypothesen en dwalingen, zij staat van nature haaks op de "esprit scientifique". 
Bernard was overtuigd van de eenheid van de wetenschap: "ll n'y a donc en réalité qu'une physique, qu'une chimie et qu'une mécanique générales, dans lesquelles rentrent toutes les manifestations phénoménales de la nature, aussi bien celles des corps vivants que celles des corps bruts" (Bernard, 1890, p. 116; vgl. ook Temkin, 1946, pp. 326-327). Het is een volstrekte vergissing om te menen dat een fysioloog bij de bestudering van de levende natuur zich zou behoren te bekommeren om het wezen en het principe van het leven. Elders vatte Bernard zijn uitgangspunten met betrekking tot de bestudering van de levende natuur als volgt samen: "L'observation et l'expérience nous apprennent que les manifestations de la vie ne sont l'oeuvre ni de la matière ni d'une force indépendante; qu'elles résultent du conflit nécessaire entre des conditions organiques préétablies et des conditions physico-chimiques déterminées. - Nous ne pouvons saisir et connaître que les conditions matérielles de ce conflit, c'està-dire le déterminisme des manifestions vitales. - Le déterminisme physiologique contient le problème de la science de la vie; il nous permettra de maîtriser les phénomènes de la vie, comme nous maîtrisons les phénomènes des corps bruts dont les conditions nous sont connues" (Bernard, 1966 (1878), p. 21). Welk onderwerp de fysioloog ook bestudeert, hij vindt slechts mechanische, fysische of chemische factoren (vgl. Bernard, 1966 (1878), p. 52), Levensprocessen moeten op dezelfde manier als processen in de dode natuur worden bestudeerd: beide zijn onderworpen aan een absoluut en noodzakelijk determinisme. Bovendien verschillen, aldus Bernard, de uitgangspunten van de levenswetenschappen niet van die van de dode natuur: "(...) il n'y a aucune différence à établir entre les principes des sciences physiologiques et ceux des sciences physico-chimiques" (Bernard, 1890, p. 40). En deze constatering heeft eveneens betrekking op de te hanteren methoden.

Opgemerkt moet worden dat het determinisme en reductionisme dat Bernard hier omarmde, verstaan behoort te worden als wetenschappelijk determinisme en reductionisme, niet als een metafysische positie. Zoals onder anderen Verwey benadrukt, was Bernard geen radicaal reductionist (Verwey, 1986, pp. 48 e.v.). Bernard stelde levensverschijnselen niet gelijk aan verschijnselen in de dode natuur. De eerstgenoemde categorie wordt zijns inziens gekenmerkt door organisatie. Maar voor de wetenschap heeft dit verschil geen relevantie, aldus Bernard. In dat geval zijn determinisme en reductie het devies.

Ook Du Bois-Reymond was van mening dat het eigen karakter van de levende natuur geen belemmering vormt voor de wetenschappelijke bestudering van lichaamsfuncties van levende wezens. Voor deze visie vond hij in de jaren veertig steeds meer medestanders (vgl. Temkin, 1946, p. 326). De grens van de mechanische natuurwetenschap, die fenomenen verklaart in termen van kracht en materie, valt volgens Du Bois-Reymond niet samen met de overgang van dode 
en levende natuur. Uiteindelijk zal de fysiologie niets anders meer zijn dan biofysica en biochemie (Du Bois-Reymond, 1848). In 1872 schetste hij in een voordracht hoe in het kader van een wetenschappelijke beschouwing tegen het onderscheid tussen levende en dode natuur moet worden aangekeken. Hij besprak dit thema aan de hand van het verschil tussen een kristal en een levend wezen. In het eerste geval bevindt de materie zich in een stabiel evenwicht, in het tweede geval in een dynamisch evenwicht, aldus Du Bois-Reymond. Beide zijn evenwel gelijkelijk onderworpen aan de wetten van de fysica: "So werden durch diese grundlegende Verschiedenheit zwischen den Individuen der todten und denen der lebenden Natur die Vorgănge in letzteren dem Gesetz der Erhaltung der Energie unterthan. Neben ihr verschwinden an Bedeutung, sofern sie nicht darin aufgehen, die von Ernst Heinrich Weber scharfsinnig ausgedachten, die beiden Classen von Individuen mehr ăusserlich trennenden Merkmale" (Du BoisReymond, 1891 (1872), p. 30).

De natuurwetenschappelijke oriëntatie in de geneeskunde noopte haar voorstanders dus tot een zekere vorm van reductionisme. Binnen dit concept van geneeskunde werd het menselijk functioneren bestudeerd als een natuurlijk organisch proces. In het verlengde hiervan ligt dat men de mens beschouwde als een organisme waarvan het functioneren op causaal-analytische wijze, dat wil zeggen als een fysisch-chemisch proces, onderzocht kan worden (vgl. Rothschuh. 1978, p. 418). Dit betekent echter niet dat de aanhangers van de natuurwetenschappelijke geneeskunde simpelweg als materialisten kunnen worden bestempeld (Galaty, 1974, p. 313). Bernard achtte bijvoorbeeld vanuit een wetenschappelijk, fysiologisch standpunt materialistische doctrines evenzeer een dwaling als vitalistische (vgl. Bernard, 1966 (1878), p. 50). De aanhangers van de natuurwetenschappelijke geneeskunde stelden zich in meerderheid uitdrukkelijk op een methodisch materialistisch standpunt. Met hun reductionisme werd geen ontologische doch een kennistheoretische stellingname beoogd (vgl. Gregory, 1977, p. 149: Verwey, 1985, pp. 190-191). Virchow meende, en met hen vele anderen, dat de geneeskunde zich niet langer met metafysische speculaties moeten ophouden. Als natuurwetenschap moest ze zich van haar grenzen bewust zijn en zich beperken tot het waarneembare: "Die Naturwissenschaft hat keine Macht über das, was ausserhalb der Erscheinungswelt ist" (Virchow, 1971 (1858), p. 27).

Als illustratie van de wijze waarop het vitalisme en de teleologie terrein verloren ten tijde van de natuurwetenschappelijk georiënteerde geneeskunde kan ook op het volgende worden gewezen. Müller was één van de meest vooraanstaande fysiologen in de eerste helft van de negentiende eeuw in Duitsland. In zijn jeugd raakte hij geïnspireerd door Goethe, aan de universiteit werd hij een aanhanger van Schellings natuurfilosofie (vgl. M. Müller, 1926, pp. 130 e.v.). Later, halverwege de jaren twintig, nam hij afstand van de natuurfilosofie. Müller was de 
leermeester van vele vooraanstaande aanhangers van de natuurwetenschappelijke geneeskunde, zoals Schwann, Lotze, Du Bois-Reymond, Brücke, Helmholtz en Virchow. De ontwikkeling en bloei van de Duitse fysiologie in deze periode zou volgens de historici van de geneeskunde ondenkbaar geweest zijn zonder zijn werk (vgl. o.a. Rothschuh, 1973 (1953), p. 123 en p. 310).

Müller was zowel een voorstander van de empirische fysiologie als een overtuigd vitalist. Lenoir plaatst hem in de traditie van het teleomechanisme (vgl. o.a. Lenoir, 1982, p. 152) Zijn vitalisme hield in dat hij veronderstelde dat er een wezenlijk onderscheid bestaat tussen organische materie en de dode natuur. Aan levensverschijnselen zou volgens hem een bepaalde kracht ten grondslag liggen. een vitaal of organisch principe (vgl. M. Müller, 1926, pp. 328 e.v.; Benton, 1974. pp. 29 e.v.). Deze kracht werkt op een manier die te vergelijken is met fysische en chemische krachten, aldus Müller, maar verschilt daarvan tegelijk in een wezenlijk opzicht. Organismen zijn opgebouwd uit combinaties van elementen die niet in de anorganische natuur voorkomen (vgl. Joh. Müller, 1833 , p. 28). De organische kracht was nu, volgens Müller, een scheppende kracht, die deze materie op een doelgerichte wijze verandert. Hij noemde haar " $(\ldots)$ die Endursache des organischen Wesens" (Joh. Müller, 1833, p. 25). In de organische natuur was het niet alleen erg ingewikkeld om opeenvolgende verschijnselen te verklaren binnen een strikt causaal-mechanisch kader. Het was volgens Müller onmogelijk. Een dergelijke fijn georkestreerde opeenvolging veronderstelde een meer doelgericht type van oorzakelijkheid (vgl. Lenoir, 1982, p. 111). Levensverschijnselen vertonen een doelmatige ordening, niet alleen bij de vorming van organen, maar ook in de meest elementaire weefselopbouw (Joh. Müller, 1833, p. 20).

Weliswaar zijn ook elders doelmatige processen te onderscheiden, bijvoorbeeld bij machines, zo constateert Müller. Maar levensverschijnselen zijn op een specifieke manier doelgericht. Het voornaamste verschil tussen door de mens ontworpen mechanieken en organismen is daarin gelegen dat het doel in het eerste geval van buiten af is opgelegd, met opzet, terwijl het doel van het organisme in het organisme zelf is gelegen (vgl. Joh. Müller, 1840, p. 505). Deze organische doelmatigheid moest volgens Müller niet alleen als een idee worden opgevat, maar als een verschijnsel dat door ervaring gekend kan worden (vgl. Joh. Müller, 1833 , p. 26; M. Müller, 1926, p. 340). Benton rekent Müllers visie op grond hiervan tot het realistisch vitalisme (Benton, 1974, p. 21 en pp. 29 e.v.).

Müllers leerlingen hebben, zoals gezegd, van hun leermeester wel zijn empirisch wetenschappelijke methoden, maar niet zijn vitalistische en teleologische principes willen overnemen. Als eerste kan hier Schwann genoemd worden, die in 1839 teleologisch-vitalistische verklaringsmodellen afwees ten gunste van een fysicalistische optiek. In het voorwoord van zijn Mikroskopische Untersuchungen uit 1839 schreef hij: "Einem Organismus liegt keine nach einer bestimmten 
Idee wirkende Kraft zugrunde, sondern er entsteht nach blinden Gesetzen der Notwendigkeit durch Kräfte, die ebenso durch die Existenz der Materie gesetzt sind, wie die Kräfte in der anorganischen Natur. Da die Elementarstoffe in der organischen Natur von denen der anorganischen nicht verschieden sind, so kann der Grund der organischen Erscheinungen nur in einer anderen Kombination der Stoffe liegen" (Schwann, 1839, geciteerd in: Vidoni, 1991, p. 28). Velen volgden in de volgende decennia Schwanns gedachtegang, en trachtten de levenskracht uit de fysiologie te weren (vgl. Temkin, 1946, p. 326; Rothschuh, 1968 b, pp. 253 e.v.; Rothschuh, 1978, p. 417; Gregory, 1977. p. 164; Lenoir, 1982, pp. 195 e.v.).

Helmholtz besprak in 1877, in een rede getiteld Das Denken in der Medicin, de ontwikkelingen in het denken over de geneeskunde. Daarbij beschreef hij met respect de opvattingen van zijn leermeester Müller, diens vitalistische ideeēn en diens opvatting van wetenschap, op de volgende wijze: "In seinen theoretischen Anschauungen bevorzugte er noch die vitalistische Hypothese, aber in dem wesentlichsten Punkte war er Naturforscher, fest und unerschütterlich: alle Theorien waren ihm nur Hypothesen, die an den Thatsachen geprüft werden mussten, und über die einzig und allein die Thatsachen zu entscheiden hatten. Selbst die Ansichten über diejenigen Punkte, welche sich am leichtesten in Dogmen versteinern, über die Wirkungsweise der Lebenskraft und die Thätigkeiten der bewussten Seele, suchte er unablässig mittelst der Thatsachen fester zu begrenzen, zu beweisen oder zu widerlegen" (Helmholtz, 1903 (1877), p. 181). Helmholtz interpreteerde Müllers vitalisme op een zodanige wijze, dat het aanvaardbaar werd vanuit een natuurwetenschappelijke wetenschapsopvatting. $\mathrm{Hij}$ beklemtoonde dat Müller zijn vitalistische denkbeelden aan de ervaring trachtte te toetsen. Het vitalisme drong bij hem dus wel door in de wetenschap, maar als een vitalistische hypothese. Het vitalisme vormde derhalve geen alternatief voor fysisch en chemisch onderzoek, maar leverde een (aanvullende) interpretatie van de aldus verworven gegevens.

Aanhangers van de natuurwetenschappelijk gedefinieerde geneeskunde bestreden niet dat het gerechtvaardigd is om er eigen religieuze en metafysische opvattingen op na te houden. $\mathrm{Zij}$ waren van mening dat dergelijke principes niet thuis horen in de wetenschap. Vitalistische concepten, zoals Müllers organische materie en zijn organisch principe, pasten volgens hen niet binnen een mechanistische wetenschapsopvatting. Ze waren hoogstens acceptabel wanneer ze hun principieel, dogmatisch karakter verloren. Müllers vitalisme was niet verwerpelijk, maar dat berustte op twee belangrijke restricties: dit vitalisme gold alleen als werkhypothese en als een (extra) verklaringsmodel. Zoals gezegd, heeft ook deze ingeperkte vorm van vitalisme bij zijn leerlingen, voorvechters van de natuurwetenschappelijke geneeskunde in tweede helft van de negentiende eeuw, allerminst navolging gevonden. 
Teleologische concepten, zoals Müllers bovengenoemde organische doelmatigheid, werden eveneens bekritiseerd. Het is wel verleidelijk om bij de bestudering van de verschijnselen in de levende natuur overal doelmatigheid, middelen en einddoelen, te zien, zo stelden de voorstanders van een natuurwetenschappelijke geneeskunde bij herhaling. Maar de bewondering voor de harmonie en doelmatigheid in de natuur dient niet te verkeren in verblinding en zelfoverschatting. Denken in doelmatigheid leidt volgens hen gemakkelijk tot willekeur. Het is immers altijd de mens die hier de doelen formuleert. "Het is de taak van den physioloog, het geheel der verschijnselen uit te vorschen, ver van de aanmatiging, het doel te willen raden, dat slechts onthuld wordt nadat men de geheele reeks der oorzaken en werkingen heeft onderkend" (Moleschott, 1989 (1862), p. 85).

De "vis medicatrix naturae", de genezende kracht van de natuur, een concept dat in de geschiedenis van de geneeskunde herhaaldelijk in meer wijsgerig getinte theorieën optreedt, viel eenzelfde relativering en herformulering als het vitalisme en het teleologisch denken ten deel. Enerzijds wees men erop dat deze veronderstelde kracht, net zomin als de levenskracht of het organisch principe, een aparte werking zou kunnen hebben, die losstaat van de fysische en chemische wetmatigheden. Anderzijds werden de verschijnselen waarvan men de verklaring had willen toeschrijven aan de natuurlijke genezingskracht, geinterpreteerd in het licht van de mechanistische natuurwetenschap. Bernard beijverde zich bijvoorbeeld om aan te tonen dat de natuurlijke geneeskracht niets anders was dan een manifestatie van bepaalde fysiologische principes. Bij verschijnselen die met behulp van de "vis medicatrix naturae" worden uitgelegd, is er naar zijn mening geen sprake van een mysterieuze kracht, maar van normale fysiologische eigenschappen, die bij ziekte op de achtergrond zijn getreden. Bij het herstel krijgen ze weer de overhand, terwijl ze bij overlijden ophouden te bestaan (vgl. Bernard, 1872 (1859/1860), pp. 64 e.v.). Concepten als de genezende kracht van de natuur en de teleologische benaderingswijze pasten evenmin als vitalistische krachten in het kader van de reductionistische en universeel opgevatte mechanistische natuurwetenschap. Dergelijke ideeën hoorden, volgens Bernard en met hem vele anderen, thuis in filosofische bespiegelingen en in de theologie.

Meer dan eens terugkerende thema's bij de aanhangers van de natuurwetenschappelijke opvatting van geneeskunde zijn de taak en de plaats van de filosofie en de metafysica. Men trachtte zich daarbij te ontworstelen aan de vooroordelen die daaruit afkomstig zouden zijn. De inzet van deze strijd tegen de filosofische benaderingswijze kan worden verhelderd door kort de verhouding van de filosofie tot de geneeskunde in de eerste helft van de negentiende eeuw te schetsen. 
In deze periode waren nogal wat wijzigingen daarin opgetreden. Eerst was de fysiologie, vooral in Duitsland, sterk in de ban van de Romantische natuurfilosofie. Deze fysiologen werden dan ook aangeduid als de natuurfilosofische school. Virchow schreef hierover in kritische zin het volgende: "Die naturphilosophische Schule baute bekanntlich ihr medicinisches System auf ihr philosophisches, und die logische Hypothese war für sie ein vollkommen berechtigtes Aequivalent für die Beobachtung" (Virchow, 1847, p. 6). Een empirische fysiologie, zo concludeerde hij, kon in dit klimaat niet van de grond komen.

$\mathrm{Na}$ de natuurfilosofische oriêntatie in de geneeskunde volgde de bloeiperiode van de natuurhistorische school van onder anderen J. L. Schōnlein (1793-1864) (vgl. Bleker, 1978; Bleker, 1983). Behalve een grotere aandacht voor observatie en experiment, werd hier voortgebouwd op concepten die afkomstig waren van de natuurfilosofische school. In het tijdperk van de natuurhistorische school raakte de geneeskunde sterk doordrongen van religieuze en metafysische ideeën. Sommigen, zoals J. N. von Ringseis (1785-1880), werkten een zondetheorie van de ziekte uit. Binnen de natuurhistorische conceptie van pathologie werd aan deductie, classificatie en abstractie een belangrijke rol toegedacht en er werd grote waarde gehecht aan bewijzen naar analogie.

Voorstanders van de natuurwetenschappelijke geneeskunde lieten in beschouwingen over het karakter van de geneeskunde hun afkeer blijken van dergelijke concepties. De kritiek van de natuurwetenschappelijk georiënteerde geneeskundigen richtte zich daarbij vooral tegen het primaat van wijsgerig verantwoorde, theoretische systemen in de pathologie. De natuurwetenschappelijke geneeskunde wilde deze als dogma verbannen (vgl. o.a. Griesinger, 1972 (1842), pp. 30-31). Men beschouwde het als een typisch euvel van vormen van geneeskunde die zich te veel door de filosofie en de metafysica laten beïnvloeden. Denken in systemen leidt tot bekrompenheid, zo stelde men, en vormt daardoor een obstakel dat bij het verwerven van kennis overwonnen moet worden ( $\mathrm{vgl}_{\mathrm{k}}$ o.a. Bernard, 1865 , pp. 351 e.v.).

In het begin van de jaren veertig van de vorige eeuw verwierp ook Lotze expliciet de uitgangspunten van de natuurhistorische school. Het ging volgens hem niet om de classificatie van ziekten, maar om het verkennen van de mogelijkheid tot wetenschappelijke verklaringen. Hij benadrukte dat het in de geneeskunde gaat om theorieën in combinatie met observatie, om het opwerpen van hypothesen en het ontwerpen van experimenten (vgl. Woodward, 1975, p. 171). Virchow verweet de natuurhistorische school een te grote aandacht voor het creềren van systemen op basis van geloof en gezag. In een artikel waarin hij terugkijkt op de ontwikkelingen in de wetenschappelijke geneeskunde van de laatste dertig jaar, beschreef hij het toenmalige verzet tegen de filosofie en met name tegen de natuurfilosofie, als volgt: "Wir kămpften gegen die aprioristische Speculation, wir verwarfen die Systeme, wir stellten uns ganz auf die Erfahrung. 
(...) Wir waren auch Feinde der Philosophie, aber nicht der Philosophie überhaupt, sondern nur der rechthaberischen, allwissenden, selbstgefälligen Philosophie der vierziger Jahre. (...) Wir bemühten uns, eine wissenschaftliche Sprache in der Medicin einzuführen und es der Willkür des Einzelnen unmöglich zu machen, durch Einfälle des Augenblicks, durch ungehöriges Generalisiren, durch die Neigung zu figürlicher Uebertragung der Begriffe die eben gewonnene Einsicht wieder zu trüben und die Vorstellung irre zu führen" (Virchow, 1877, pp. 2 e.v.).

De meeste voorstanders van een natuurwetenschappelijke geneeskunde namen, zeker naarmate hun wetenschapsconcept meer verspreid raakte, ten opzichte van metafysische vragen een agnostische houding in (vgl. o.a. Vidoni, 1991, p. 153). Tekenend in dit verband is Du Bois-Reymonds bespreking van het leven en denken van de verketterde J. Offray de La Mettrie (1709-1751) (Du BoisReymond, 1875). Du Bois-Reymond haalde daar naar voren dat 120 jaar tevoren La Mettries opvattingen, gepubliceerd in onder andere Histoire naturelle de l'Ame. L'Homme machine van 1748, schokkend waren. La Mettrie verwierp Descartes' dualisme; voor hem was er slechts één substantie, bestaande uit een verbinding van lichaam en geest. Maar recentelijk, zo constateerde Du Bois-Reymond, worden op metafysisch niveau verschillende opvattingen verdedigbaar geacht en worden monisme en dualisme beide als mogelijke wereldbeschouwing geaccepteerd. Tegenwoordig schijnt het ons wel geoorloofd en zelfs nuttig om vanuit verschillende standpunten fundamentele problemen te benaderen en zo bijvoorbeeld een mechanistische wereldtheorie te formuleren, aldus Du Bois-Reymond (vgl. Du Bois-Reymond, 1875, p. 28).

Het belang van het werk van La Mettrie was zijns inziens daarin gelegen, dat hij de methoden van de natuuronderzoeker hanteerde. "Fort aus dem Studirzimmer, von den staubigen Pergamenten der Philosophen und Theologen (was konnten sie viel von der Seele wissen?), hat er die Forschung auf die Erfahrungen der Aerzte, die Entdeckungen der Naturforscher als auf den wahren Quelle der Erkenntnis in diesem Gebiete verwiesen" (ibid., p. 25). In La Mettries tijd ontbrak het aan bevredigende methoden tot onderzoek van de ziel. Maar door eenvoudigweg als natuuronderzoeker te werk te gaan, ontdekte La Mettrie de juiste, inductieve, methode. Du Bois-Reymond beschouwde hem om deze reden als wegbereider voor de juiste werkwijze, die hij als volgt beschrijft: "Er [de natuuronderzoeker, $\mathrm{IWH}]$ wird die geistigen Erscheinungen wohl als ganz besondere Klasse der ihn umgebenden Erscheinugen auffassen, sonst aber bei deren Zergliederung und Ergründung so verfahren, wie gegenüber jeder anderen neu hervortretenden Thätigkeitsäusserung der Materie, z.B. der Elektricität" (ibid., p. 24). Nu de wetenschap qua importantie niet langer onderdoet voor de metafysica maar veeleer het omgekeerde het geval is, is La Mettrie zeker van belang. 
aldus Du Bois-Reymond. Het is bij gevolg niet zozeer nodig om La Mettries metafysische stellingname te bestrijden, als wel om diens wetenschappelijke principes voor het voetlicht te halen.

Helmholtz besprak in zijn eerdergenoemde rede Des Denken in der Medicin eveneens de historische ontwikkeling van de verhouding tussen filosofie en geneeskunde. Eertijds volgde de natuurwetenschap en daarmee ook de geneeskunde het pad van de filosofie. De deductieve methode scheen alles te vermogen (Helmholtz, 1903 (1877), p. 173). In de loop der tijd is deze verhouding echter grondig gewijzigd, constateert hij. Dogmatisme en metafysica hebben hun bevoorrechte positie moeten opgeven. Speculatieve methoden en deductieve verklaringsmodellen hebben plaatsgemaakt voor waarneming en inductie. De gewetensvolle arts die handelend wil optreden in het spel van heil en verderf brengende krachten, heeft immers als enig doel het zoeken van de waarheid. Ware kennis van de feitelijke wetmatigheden, waarop de arts zijn ingrijpen kan baseren, vindt men uitsluitend door waarneming, experiment en inductie. Pas in tweede instantie moeten er consequenties uit de wet getrokken worden en worden gededuceerd. Deze resultaten moeten vervolgens aan de ervaring worden getoetst. Dit proces van voortdurend twijfelen houdt, aldus Helmholtz, nooit echt op (ibid., p. 183).

Metafysische stellingnamen zijn hoogstens toelaatbaar als hypothesen, die binnen de wetenschap vruchtbaar kunnen zijn. Als dogma's staan ze evenwel de ontwikkeling van de wetenschap in de weg. Dat betreft niet alleen de ontwikkeling van de geneeskunde. De echte wetenschap der filosofie heeft ook en misschien nog wel meer te lijden gehad van de metafysica, volgens Helmholtz. En dat is bedenkelijk, aangezien de filosofie zich tot de metafysica verhoudt als astronomie tegenover astrologie. Een metafysische gevolgtrekking is volgens de bekende uitspraak van Helmholtz "(...) entweder ein Trugschluss oder ein versteckter Erfahrungsschluss" (ibid., p. 189). De filosofie zou volgens Helholtz de metafysica moeten opgeven en zich moeten beperken tot het aangeven van een wetenschappelijk fundament voor de andere wetenschappen. Wat overblijft als onderzoeksterrein voor de filosofie is "die Kenntniss der geistigen und seelischen Vorgänge und deren Gesetze", een soort experimenteel wetenschappelijke kennistheorie (vgl. Helmholtz, 1903 (1877), pp. 188-189). Alleen op deze wijze kan een degelijke basis worden verkregen voor de praktische activiteiten van artsen, juristen en politici.

De aanhangers van de natuurwetenschappelijke geneeskunde bekritiseerden dus niet alleen de vermenging van wetenschap en metafysica. Zij waren ook van mening dat de natuurwetenschap de leidinggevende positie van de filosofie heeft overgenomen. Müller schreef in 1834 dat de filosofie ons heeft geleerd om waarnemingen te waarderen en te analyseren (Joh. Müller, 1834, p. VII). Zijn leerling en opvolger als hoogleraar te Berlijn, Du Bois-Reymond, hield er in 1872 een 
geheel andere opvatting op na: "Allein die Philosophie kan Nutze aus der Naturforschung ziehen, nicht aber umgekehrt die Naturforschung aus der Methode der Philosophie" (vgl. Schipperges, 1977, pp. 318-319). Terwijl in de eerste fase van de genese van het mechanistisch wetenschapsconcept het zwaartepunt nog lag bij de filosofie, ging in het vervolg deze voorrangspositie verloren (vgl. Verwey, 1980, p. 63 en pp. 74-75).

In het bovenstaande is een globale schets gegeven van de uitgangspunten die verbonden zijn met de negentiende-eeuwse natuurwetenschappelijke conceptie van geneeskunde. De voorrang van de empirie, de nadruk op experiment en observatie, de gerichtheid op het procesmatige karakter van de te onderzoeken verschijnselen, het reductionistisch natuurbegrip, het mechanistisch wetenschapsideaal en de waardering van de filosofie zijn de revue gepasseerd. Tegen deze achtergrond zal nu nader worden ingegaan op het ziektebegrip en vervolgens op het klinisch oordeel in de natuurwetenschappelijke geneeskunde.

\subsection{Het riektebegrip in de natuurwetenschappelijke geneeskunde}

De voorstanders van de natuurwetenschappelijke oriêntatie stonden voornamelijk kritisch ten aanzien van hun voorgangers. De geschiedenis van de geneeskunde werd niet langer beschouwd als een waardevolle en nog steeds actuele bron van informatie. Als men vroegere opvattingen beschreef, diende dat om het contrast met het intussen bereikte aan te geven. In de geschiedenis van de eigen discipline konden hooguit enkele positieve momenten en ideeën worden opgespoord. Daarnaast hebben de aanhangers van de natuurwetenschappelijke geneeskunde zich fel verzet tegen in hun ogen verouderde, veelal metafysische en religieuze, opvattingen in de geneeskunde. Het recent aangebroken tijdperk van de natuurwetenschappelijk gedefinieerde geneeskunde leverde naar hun mening pas een werkelijk bevredigende vorm van geneeskunde.

$\mathrm{Bij}$ het verzet tegen de dwalingen uit het verleden, moesten vooral de onmiddellijk aan de natuurwetenschappelijke geneeskunde voorafgaande stromingen in de geneeskunde het ontgelden. Deze kritiek op oudere opvattingen, alsmede de vernieuwingsdrang en het geloof in vooruitgang treden bijzonder helder aan de dag bij de strijd rond het ziektebegrip. De verwerping van het vitalisme, de teleologie, de metafysica en het speculatieve systeemdenken in het algemeen, was ten tijde van de opkomst van de geneeskunde als natuurwetenschap onlosmakelijk verbonden met de poging tot formulering van een nieuw ziektebegrip. Van degenen die voorop hebben gelopen bij de thematisering en herziening van het ziektebegrip, moet met nameVirchow worden genoemd. Virchow was, zoals gezegd, een leerling van de fysioloog Müller en hij wordt door velen beschouwd 
als de meest bekende en invloedrijke medicus uit de tweede helft van de negentiende eeuw (vgl.Ackerknecht, 1959 (1955), p. 134; vgl. Rather, 1971 (1958), p. 11). Ook op de Nederlandse geneeskunde van die periode had hij grote invloed (vgl. o.a. Stokvis, 1901). Hij verrichtte op uiteenlopende terreinen onderzoek, maar zijn grootste faam verwierf hij met zijn werk op het gebied van de cellulaire pathologie.

In talrijke geschriften heeft Virchow zijn visie op ziekte duidelijk naar voren gebracht. Zijn bemoeienis met de formulering van een nieuw ziektebegrip paste in zijn streven naar de emancipatie van de pathologie, die hij wilde verheffen tot natuurwetenschap (vgl. Virchow, 1877, p. 9). Het object van de pathologie is, aldus Virchow, ziekte. De pathologie noemt hij "die Lehre von der Krankheit" (Virchow, 1975 (1869), p. 74).

Virchow plaatste in 1847, in het eerste artikel van het door hem in hetzelfde jaar opgerichte Archiv für pathologische Anatomic und Physiologie und für klinische Medizin, de kwestie wat er onder ziekte behoort te worden verstaan, op de voorgrond (Virchow, 1847). Hij verklaarde daarbij met nadruk dat ziekten in de wetenschappelijke geneeskunde niet, zoals eertijds, als zelfstandige entiteiten moeten worden opgevat. Tegenwoordig wordt erkend, zo schreef hij. “(...) daB Krankheiten nichts für sich Bestehendes, in sich Abgeschlossenes, keine autonomischen Organismen, keine in den Körper eingedrungene Wesen, noch auf ihm wurzelnde Parasiten sind, sondern daß sie nur den Ablauf der Lebenserscheinungen unter veränderten Bedingungen darstellen, (...)" (Virchow, 1847.p. 3). Ziekten zijn geen bijzondere entiteiten, ze vormen evenmin een aparte categorie van verschijnselen (vgl. ook Virchow, 1849, pp. 45-46). Voor Virchow waren ziekten de uitdrukking van leven onder ongunstige omstandigheden, zij vormden verstoringen van normale processen.

Virchow verklaarde dat het in de pathologie niet langer gaat om het construeren van theoretische en speculatieve nosologische systemen, waarbij ziekten op grond van bepaalde overeenkomsten worden gegroepeerd. De enig zinvolle systemen in dit vakgebied zijn empirisch gefundeerde aetiologische systemen: "Die Systeme der Krankheiten gehören in die Vergangenheit, die Systeme der Bedingungen sind die einzig möglichen, und die Forderung (...) eine ätiologische Medicin zu errichten, ist eine vollkommen berechtigte" (Virchow, 1849, p. 20). In 1869 stelde Virchow, na een bespreking van verschillende stromingen in de geschiedenis van de geneeskunde, die alle op zoek waren geweest naar het wezen van ziekte: "Wir kommen also vom Gedanken zurück, daß das Wesen der Krankheit überhaupt zu suchen sei. Es gibt kein Wesen der Krankheit, (...)" (Virchow. 1975 (1869), p. 84). Wat ziet men immers aan het ziekbed? Een strijd tussen een lichaam en iets vreemds, een vreemde substantie, een vreemd organisme of een vreemd wezen dat zich in het lichaam heeft binnengedrongen? Neen, zo betoogde Virchow, in de regel ziet men een lichaam dat strijd levert. En daaruit vloeit het inzicht voort, aldus Virchow, " $(. .$.$) daß die Krankheit ein Lebensvorgang$ 
ist, überhaupt nicht ein Wesen, sondern ein Vorgang, der durch eine gewisse Sukzession von Zuständen verlāuft, von denen der eine mit einer gewissen Notwendigkeit aus dem anderen hervorgeht" (Virchow, 1975 (1869), p. 85).

De opvatting van ziekte waar Virchow zich in deze passages tegen verzette, is het ontologisch ziektebegrip. Dit karakteriseerde hij als volgt: "Jahrtausende hindurch hat man die Krankheit ontologisch als etwas für sich Bestehendes und in sich Begründetes aufgefa $B t$, und demgemä $B$ den dualistischen Gegensatz von Gesundheit und Krankheit anerkannt" (Virchow, 1849, p. 24). Volgens de ontologische visie - die geenszins definitief is verdwenen sinds de opkomst van de natuurwetenschappelijke geneeskunde - moet ziekte worden begrepen als een reële entiteit, als een bijzonder en op zichzelf bestaand gegeven. Daardoor ontstaat er een radicaal verschil tussen ziek en gezond. (Vgl. o.a. Riese, 1953, pp. 78 e.v.). Binnen het kader van een ontologisch ziektebegrip is het zinvol om te spreken van het "wezen" van de ziekte. Dat wezen kan variêren van chemische stoffen, humores of parasieten tot de duivel zelf. Een dergelijk ziektebegrip had onder andere aanleiding gegeven tot de constructie van gecompliceerde nosologieên, de bovengenoemde, door Virchow gehekelde, "Systeme der Krankheiten". Verschillende ziektes werden als biologische entiteiten opgevat, vergelijkbaar met planten, en als zodanig in families ondergebracht en als species gerubriceerd.

Virchows poging te breken met het ontologisch ziektebegrip stond niet op zichzelf. De opkomst van de natuurwetenschappelijke oriëntatie in geneeskunde ging. zoals al eerder is aangegeven, gepaard met een kritische beschouwing van de geschiedenis van de geneeskunde. In het tijdperk van de natuurfilosofische en vervolgens de natuurhistorische school, die in tijd vlak voor de natuurwetenschappelijke oriëntatie in de geneeskunde moeten worden geplaatst, had het ontologisch ziektebegrip juist een ware bloeiperiode doorgemaakt (vgl. Pagel, 1931, p. 10; Bleker, 1981, o.a. p. 139). Daarbij werd teruggegrepen op het concept van Paracelsus (1493-1541), van ziekte als parasiet. Binnen deze scholen, en dan met name de natuurhistorische, werd aan ziekte een eigen individualiteit toegedacht. Ziekte werd opgevat als een vreemde gast die als een parasiet leeft in het menselijk lichaam. Deze parasiet bevindt zich weliswaar op een laag niveau van organisatie, maar is toch een opzichzelfstaand levend wezen. De consequentie van deze visie was dat essentie en oorzaak van ziekte met elkaar werden geïdentificeerd. Overigens werd ziekte tegelijkertijd gezien als een onderdeel van de natuurgeschiedenis, als een bijzonder geval in het algemene biologische proces (vgl. Diepgen, 1926, p. 303).

Vanaf de jaren veertig van de negentiende eeuw werden dergelijke natuurfilosofische en natuurhistorische stellingnamen scherp aangevallen. W. Roser (18171888) en de eerdergenoemde Wunderlich, voormannen van de fysiologische geneeskunde, één der stromingen binnen de natuurwetenschappelijk georiênteerde geneeskunde, keerden zich indertijd uitdrukkelijk tegen het ontologisch 
ziektebegrip. Zij wezen op de dwalingen en gevaren die ermee verbonden zijn en gaven zo een beeld van de bezwaren die de natuurwetenschappelijke geneeskundigen telkens weer tegen het ontologisch ziektebegrip hebben ingebracht. "Ins Blaue hinein wurden specifische Ursachen vorausgesetzt, pathognomonische Symptome angenommen, Grenzen und Unterschiede zwischen den einzelnen Species festgesetzt. War erst der Name der Krankheit, die Species aufgefunden, so hatte man auch sogleich, auf die Autorität irgend eines Professors oder Receptcomponisten hin, die Curirformel bei der Hand, der Kranke war versorgt, und das wissenschaftliche und andre Gewissen beschwichtigt. - So hat die Idee der Krankheitsspecies dem gröbsten Empirismus zur Einführung gedient" (Roser \& Wunderlich, 1975 (1842), pp. 50-51). Er bestaan, zo stelden zij, weliswaar enige terechte groeperingen in symptomen en er is wel iets kenmerkends te onderscheiden bij tyfus of cholera. "Aber das Specifische ist nicht ein Ens ein Krankheitsorganismus, dessen Aeusserung die Symptome wären. Sondern die specifische Eigenthümlichkeit der Erscheinungen hat nur eine aetiologische Finheit. Es ist dasselbe Contagium, dasselbe Miasma, mit Einem Wort, dieselbe specifische Ursache, welche gleichartige Reaction des Organismus, gleichartige Form der Erkrankung veranlasst. (...) Dem Ontologen dagegen ist die vorausgesetzte Krankheitseinheit ein Dogma (...) Als Aufgabe gilt ihm, von dieser Einheit ein scharfes, ideales Bild zu entwerfen, und in dem concreten Fall die ideale Abstraction wieder zu erkennen. So wurde die specielle Pathologie zur Nosologie, zu einer Sammlung von Definitionen und Krankheitsbildern mit angehångten Receptformeln" (Roser \& Wunderlich, 1975 (1842), pp. 51-52). Griesinger, met Roser en Wunderlich oprichter van het Archiv für physiologische Heilkunde, richtte zijn bedenkingen tegen de ontologische ziekteleer van zijn leermeester Schönlein vooral op het analytisch-descriptieve karakter van diens ziektebeelden. De fysiologische geneeskunde stelde daar tegenover dat de ziekte niet een abstracte definitie is, die van toepassing is op alle individuen. Griesinger beschreef zijn opvatting als volgt: "(...) das Wesen, der Begriff der Krankheit geht ihr erst aus der ganzen Geschichte der Krankheit, aus der Erkenntnis aller und jeder Details der pathologischen Vorgänge, der succesiven Aufeinanderfolge der quantitativen und qualitativen Functionsstôrungen hervor" (Griesinger, 1872 (1842), p. 65). Het bezwaar tegen een statische conceptie van ziekte, dat hier werd verwoord door Griesinger, werd door alle voorstanders van een natuurwetenschappelijke geneeskunde gedeeld. Wanneer het lijden aan een bepaalde ziekte wordt gekoppeld aan het zich al of niet voordoen van een bepaalde stand van zaken, bijvoorbeeld het vertonen van zekere anatomisch aanwijsbare eigenaardigheden, vervalt men gemakkelijk tot een reificatie van ziekte. De identificatie van deze stand van zaken met het wezen, de essentie, van deze ziekte ligt immers vervolgens voor de hand. Aldus zou het ontologisch ziektebegrip weer de kop op steken. 
Daarenboven gold dat als de pathologie een dergelijk statisch ziektebegrip zou hanteren, zij zich net als de anatomie te veel zou beperken tot een descriptieve werkwijze. Zo zou zij ten onrechte voorbij gaan aan haar taak wetmatigheden te formuleren. Ziekteverschijnselen moeten vanuit wetenschappelijk perspectief in een kader van tijd en causaliteit worden geplaatst en met elkaar in verband worden gebracht. Zoals Virchow schreef: "Die eigentliche Wissenschaft hebt erst mit der Geschichte der Körper an; sie forscht nach dem Mechanismus und den Bedingungen ihres Entstehens und Entwickelns, nach den zeitlichen und ursächlichen Beziehungen zwischen den Körpern; sie hat es weniger mit den Körpern selbst, als mit den Vorgāngen an den Körpern, mit der Erscheinung und der Bewegung zu thun" (Virchow, 1847,p. 11). Met de opkomst van de natuurwetenschappelijke oriëntatie in de geneeskunde wordt dus het object van de pathologie anders opgevat en treedt de ontwikkeling van ziekte, als een aan bepaalde voorwaarden gebonden proces, meer op de voorgrond.

Lotze en Henle, twee andere vooraanstaande auteurs van beschouwingen over de pathologie ten tijde van de opkomst van de natuurwetenschappelijke oriëntatie in de geneeskunde, verwierpen in dezelfde jaren veertig eveneens met nadruk het ontologische ziektebegrip (Lotze, 1842; Henle, 1846; vgl. Woodward, 1975. pp. 146-147). Beiden bepleitten een niet-essentialistisch concept van ziekte, dat ziekte beschouwt als een gebeuren en niet als een toestand. Zij vatten ziekte op als een afwijking van het normale levensproces, volgens welke organische wezens zich ontwikkelen (vgl. Henle, 1846, p. 89). Het ziektebegrip van de natuurhistorische school was ook in de ogen van Lotze en Henle achterhaald. Het diende naar hun mening te worden vervangen door een visie die ziekte beschouwt vanuit het perspectief van het geheel van mechanische processen in de wereld.

Ook het andere doorVirchow genoemde uitvloeisel van het ontologisch ziektebegrip, de dualistische tegenstelling tussen ziekte en gezondheid, werd aangevallen (vgl. o.a. Virchow, 1849, p. 24). De hierboven aangehaalde voorstanders van de natuurwetenschappelijke geneeskunde, en met hen vele anderen, zoals bijvoorbeeld Bernard, stelden dat er vanuit wetenschappelijk oogpunt geen kwalitatief onderscheid bestaat tussen ziekte en gezondheid (vgl. wat betreft Bernard, o.a. Canguilhem, 1978 (1966), p. 30). Ziekteverschijnselen zijn volgens Virchow niet te verklaren uit een strijd tussen twee tegengestelde factoren, enerzijds ziekte en anderzijds gezondheid of leven. Ziekte is evenmin de strijd tussen enerzijds het leven en anderzijds externe factoren. Ziekzijn is niets anders dan een bepaalde manier van leven. Virchow verdedigde dit gezichtspunt in 1849 met de woorden: "(...) die Krankheit das Leben selbst ist, welches wegen des Wechsels der äußeren Dinge, unter veränderten Bedingungen, in anderer Form zur Erscheinung kommt, daß hier nirgend ein Kampf ist, sondern nur ein Ablauf gesetzmāßiger, ausnahmeloser Vorgānge und das der immanente Grund dieser 
Vorgänge, die Lebensgesetze fort und fort dieselben bleiben" (Virchow, 1849, p. 26). In de daaropvolgende jaren bleef hij deze visie trouw, ziekte is en blijft voor Virchow een "Lebensvorgang".

Ziekte bezit op zich geen eigen existentie, zo meendeVirchow, " (...) die Krankheit als solche gehört dem lebendigen Körper an, sie ist davon untrennbar, wir kōnnen sie wohl in unserer Vorstellung davon abtrennen, wir kōnnen abstrahieren, aber wir können sie nicht als eine wirklich für sich bestehende Existenz zugestehen" (Virchow, 1975 (1869), p. 85). Ziekte moest volgens Virchow niet worden opgevat als een extern gegeven, maar als een proces binnen het lichaam. $\mathrm{Zij}$ moest niet tot een vijandig individu worden gepersonifieerd. Ziekten zijn geen afzonderlijke organismen die in de werkelijkheid zijn te onderscheiden, aangezien ze altijd zijn gebonden aan lichamen. Het is derhalve niet adequaat om in ons denken over ziekte haar een van de mens geisoleerde existentie toe te dichten. Ziekte is, zoals we eerder zagen, leven onder veranderde, abnormale omstandigheden. Ziekten ontstaan wanneer het lichaam een afwijkende invloed niet meer teniet kan doen. "Die Krankheit beginnt in dem Augenblicke, wo die regulatorische Einrichtung des Körpers nicht ausreicht, die Stōrungen zu beseitigen. (...) die Krankheit beginnt mit der Insuffizienz der regulatorischen Apparate" (Virchow, 1975 (1869), p. 87).

De in de praktijk niet te miskennen kloof tussen ziek en gezond wilde Virchow overbruggen met behulp van het begrip "leven". "Die Krankheit hat keine andere Einheit, als die Gesundheit, als das Leben überhaupt" (Virchow, 1849, p. 26). Ziekte en gezondheid werden door hem beide opgevat als vormen van leven, respectievelijk als leven onder veranderde en als leven onder natuurlijke omstandigheden (vgl. Pagel, 1931, p. 15). Het onderscheid tussen ziek en gezond, dat in de ontologische opvatting van ziekte binnen de natuurhistorische school als een fundamenteel verschil naar voren kwam, werd door Virchow gerelativeerd doordat hij elk herleidde tot het niveau van de levensverrichtingen (vgl. Ribbert, 1899, p. 226).

De stelling dat ziekteverschijnselen niet geïsoleerd, als een aparte categorie, moesten worden beschouwd, heeft uiteraard ook consequenties gehad voor de pathologie. Als deze verschijnselen niet principieel verschilden van andere levensverschijnselen, moest de conclusie luiden dat de pathologie zich niet met kwalitatief andere verschijnselen bezighoudt dan de fysiologie. Virchow stelde daarom ook dat hij geen fysiologische pathologie, maar een pathologische fysiologie voorstond: "Die Pathologie muß in die Physiologie aufgehen, der Begriff der Krankheit von seiner exceptionellen und ontologischen Bedeutung befreit werden" (Virchow, 1849, p. 19). De pathologie vormde derhalve een onderdeel van de fysiologie. Oftewel, zoals Van Geuns Virchow parafraseerde, de pathologie is nu slechts de fysiologie met hindernissen (vgl. Van Geuns, 1857, p. 229). 
Bernard beklemtoonde herhaaldelijk als één van de basisprincipes in zijn conceptie van de geneeskunde, dat er vanuit wetenschappelijk oogpunt geen verschil is tussen pathologie en fysiologie. Er waren zijns inziens bij de verklaring van ziekte geen wetten of krachten in het spel, die van een wezenlijk andere aard zijn dan die worden gehanteerd bij de verklaring van andere levensprocessen: “(...) aucune entité pathologique, aucun principe abstrait ne nous est nécessaire pour expliquer les faits" (Bernard, 1872 (1859/1860), p. 52).

Het leven was volgens Virchow, die hieromtrent een toentertijd gangbare mening uitdroeg, te begrijpen als een mechanisch proces. De levende natuur is, evenzeer als de dode natuur, onderworpen aan de wetten van de fysica en de chemie. Dit wil niet zeggen dat het leven volgens Virchow geen enkel verschil vertoonde met de mechanische processen in de dode natuur: "Mechanik und Leben sind nicht identisch, sondern Leben ist nur eine besondere Art der Mechanik und zwar die allercomplicirteste Form derselben, (...)" (Virchow, 1849, p. 14). Het onderscheid tussen mechanica en leven was vanuit het perspectief van de natuuronderzoeker een gradueel onderscheid. Er konden weliswaar bepaalde vragen worden gesteld over de eigen aard van het leven, maar dan zou men buiten het domein van de wetenschap treden.

De specifieke verschijningsvorm van de levende natuur was volgens Virchow de cel. De cel vormt de organische eenheid van de levende natuur. In de woorden van Virchow: "der Gedanke von der Einheit des Lebens in allem Lebendigen findet in der Zelle seine leibliche Darstellung" (Virchow, 1858, in Krafft (Hrsg.), 1971 , p. 11). Voor cellen gelden, evenals voor levende lichamen, de algemene chemische en fysische wetmatigheden. Iedere kenmerkende eigenschap van het menselijk leven was zijns inziens wetenschappelijk te verklaren als het verloop van cellulaire processen waarop anatomische en chemische factoren invloed uitoefenen. "Das Geheimniß der Individualität besteht unzweifelhaft in den feinen Verschiedenheiten der Anlage und Ausbildung einzelner Zellen oder Zellengruppen" (Virchow, 1859, in Krafft (Hrsg.), 1971, p. 64). Zowel ziek als gezond zijn omschreefVirchow als bepaalde rangschikkingen en processen binnen het lichaam op het niveau van de cellen. "Das Leben ist die Thătigkeit der Zelle, seine Besonderheit ist die Besonderheit der Zelle" (Virchow, 1858, in Krafft (Hrsg.), 1971, p. 11). Deze specifieke eigenaardigheden zouden met behulp van de mechanische natuurwetenschap kunnen worden verklaard (vgl. ibid. p. 14). Virchow lokaliseerde ziekte derhalve in lichamelijke processen, die met behulp van natuurwetenschappelijke methoden aanwijsbaar zijn. In tegenstelling tot zijn voorgangers plaatste hij ziekte niet in een orgaan, maar binnen de celprocessen. Ziekte stond bij hem niet gelijk aan een anatomisch aanwijsbare afwijking, doch aan een plaatsgebonden, empirisch vaststelbaar en abnormaal gebeuren op cellulair niveau. Volgens Virchow vormde dit het niveau waarop het lichamelijk 
functioneren zich in feite afspeelt: "Wir sind in der Kenntnis der Zellenelemente endlich an den Punkt gelangt, wo wir die wirklich tãtigen Bestandteile des menschlichen Leibes vor uns haben, nicht mehr die geistigen, sondern die sichtbaren Elemente, die elementaren, die schaffenden, die tätigen Organismen" (Virchow, 1975 (1869), pp. 90-91). Het verschil tussen ziek en gezond werd door Virchow vertaald in verschillende cellulaire processen, zoals elk bijzonder kenmerk van het leven werd verklaard door bepaalde rangschikkingen en lichamelijke processen op cellulair niveau.

Het belangrijkste kenmerk en tegelijkertijd het vernieuwende van Virchows ziektebegrip is, dat de nadruk werd gelegd op het procesmatige karakter van ziekte. Het object van de pathologie, de "krankhafte Verrichtungen", waren zijns inziens de abnormale patronen op celniveau. Deze patronen voltrekken zich in de tijd volgens bepaalde fysische en chemische wetmatigheden. Ziekte werd door Virchow dus niet gefixeerd tot een bepaalde, anatomisch te constateren toestand, die principieel verschilt van gezondheid. In de medische wetenschap zou men dan immers niet verder komen dan louter descriptie en classificatie. Virchow beschouwde ziekte als een geordend proces, als een verzameling gegevens over lichamelijk functioneren die door de wetenschap met elkaar in verband kunnen worden gebracht. Door oog te hebben voor het wetmatig karakter van het ziekteverloop werden het verklaren, voorspellen en beheersen hiervan mogelijk. Virchows ziektebegrip gaf aldus een kader aan waarbinnen een wetenschappelijk verantwoorde geneeskundige praktijk mogelijk was.

Ondanks deze fundamentele vernieuwing zijn in Virchows ziektebegrip in zekere zin ontologische trekken behouden gebleven. Ook door hem werd de gewraakte overstap gemaakt van concept naar concrete realiteit. In zijn latere geschriften treedt deze tendens duidelijker aan het licht, met name als hij over de cel als een "ens morbi" spreekt (Virchow, 1895, pp. 35-36; vgl. Riese, 1953. p. 61 e.v. en p. 78 e.v.; Kräupl Taylor, 1979, p. 12 en pp. 15-16). De cel is: “(...) the fundamental unit of disease" (Rather, 1971 (1958), p. 16). Op grond van hiervan is Virchows ziektebegrip wel als ontologisch bestempeld.

Evenals zijn ontologisch georiênteerde voorgangers beschouwde Virchow het vertonen van bepaalde aantoonbare afwijkingen als het criterium voor ziek zijn. Deze afwijkingen werden weliswaar niet geïdentificeerd met één bepaalde toestand, ze werden beschouwd als een proces in de tijd. Maar dat neemt niet weg dat ook Virchow een materieel criterium hanteerde voor het hebben van, of lijden aan, een bepaalde ziekte. Ziekte is dan geen abstract begrip meer, maar iets in de werkelijkheid. Er vond hierdoor bij Virchow, evenals bij de pathologisch anatomen en de aanhangers van de natuurhistorische school, een reïficatie van het begrip "ziekte" plaats. Dat wil zeggen, ziekte werd gelijkgesteld aan een objectief vaststelbare serie van feiten, de eerder genoemde "Sukzession von 
Zustânden", die een bepaald noodzakelijk patroon doorlopen. Virchow verbindt aldus de titel "ziek" aan in de werkelijkheid voorkomende entiteiten, aan een specifiek cellulair proces.

Zoals eerder is betoogd waren er in Virchows karakterisering van de "krankhafte Verrichtungen" belangrijke verschillen met de door hem gewraakte opvattingen van enerzijds de Parijse en Weense scholen en de natuurhistorische school anderzijds. Virchow verwierp het pathologisch-anatomisch ziekteconcept van de eerstgenoemden op grond van het statisch karakter. Daar tegenover presenteerde hij ziekte als een zich in tijd en ruimte afspelend mechanisch proces. Terwijl de laatstgenoemden ziekte opvatten als een agressief subject, werd door Virchow ziekte beschouwd als leven onder veranderde omstandigheden. Maar doordat hij de nadruk bleef leggen op de aanschouwelijkheid en toetsbaarheid, op empirisch waarneembare gegevens die in fysische en chemische termen zijn te verwoorden, heeft Virchow zich niet helemaal kunnen losmaken van het ontologisch ziektebegrip. Het lokaliserende anatomische ziektebegrip werd in tweede instantie toch weer omarmd om een objectief criterium te verschaffen voor ziekte.

Tot op hoge leeftijd is Virchow evenwel aspecten van het ontologisch ziektebegrip blijven bestrijden. Hij heeft zich steeds verzet tegen statische opvattingen van ziekte, tegen een dualistische tegenstelling tussen ziek en gezond en tegen het idee van een ons belagend vijandelijk organisme, dat het wezen van een ziekte zou uitmaken (vgl. Virchow, 1895).

De hierboven geschetste visie van Virchow kan als kenmerkend voor de negentiende-eeuwse natuurwetenschappelijke oriëntatie in de geneeskunde worden beschouwd. De binnen deze stroming gepropageerde empirische gerichtheid, leidde in combinatie met het streven naar de formulering van mechanische wetmatigheden met betrekking tot het functioneren van het menselijk lichaam, tot onderling sterk gelijkende opvattingen.

De voorvechters van de natuurwetenschappelijke geneeskunde definieerden ziekte en gezondheid als bepaalde in de werkelijkheid aantrefbare processen. Andere aspecten van ziekte, zoals pijn, vielen vanuit deze optiek buiten het bereik van de wetenschap. Zintuiglijke gewaarwordingen lagen volgens hen aan gene zijde van een onoverbrugbare kloof. Du Bois-Reymond concludeerde in een onderzoek naar de grenzen van de natuurwetenschap dat gevoelens van vreugde, schoonheid, pijn of verdriet, net zomin als bijvoorbeeld de vrije wil, ooit door een mechanistische natuurwetenschap begrepen zouden kunnen worden (vgl. Du Bois-Reymond, 1891 (1872), p. 42 e.v.).

De exclusieve aandacht voor de materiële afwijking hing ten nauwste samen met het gehanteerde wetenschapsconcept. In de ogen van de aanhangers van de 
natuurwetenschappelijke geneeskunde kon men slechts wetenschap bedrijven omtrent materiēle zaken. Alleen de materiēle wereld gehoorzaamt aan causale wetmatigheden en is een aaneenschakeling van oorzaak en gevolg. De kennis daarvan, zo meende men, bevredigt de behoefte aan het zoeken naar causale verbanden. Geestelijke processen zijn daarentegen principieel onttrokken aan een dergelijke mechanische causaliteit en derhalve niet in wetenschappelijke zin te begrijpen (vgl. ibid., p. 41 e.v.; Du Bois-Reymond, 1891 (1880), p. 89). Het materiêle, de dode én de levende natuur, is met behulp van één methode, die der natuurwetenschappen, wetenschappelijk te bestuderen, terwijl het geestelijke zich volledig aan enige methodische bestudering onttrekt.

De aanhangers van een natuurwetenschappelijk gedefinieerde geneeskunde verwierpen met kracht zowel het natuurhistorische ontologische als het anatomische ziektebegrip van hun voorgangers. Zij deelden een voorkeur voor kwantitatief experimenteel onderzoek en een geloof in de alom in de natuur geldende mechanische causaliteit. $\mathrm{Zij}$ hadden een uitgesproken afkeer van vitalistische denkbeelden en spraken zich uit voor een, op zijn minst methodische, gelijkschakeling van de dode en levende natuur. Deze uitgangspunten droegen tezamen bij tot een herziening van het concept "ziekte" als object van onderzoek in de natuurwetenschappelijke pathologie. Ziekte was, volgens de toenmalige nieuwe natuurwetenschappelijke definiëring, een objectief waarneembaar, door fysische en chemische wetmatigheden gestuurd, materieel, lichamelijk proces.

\subsection{Het klinisch oordeel in de natuurwetenschappelijke geneeskunde}

De hervormingen in de geneeskunde rond 1850 hebben zich niet beperkt tot wijzigingen in de opvattingen betreffende het domein van de geneeskunde. Het nieuwe op de natuurwetenschappen geënte wetenschapsconcept had ook gevolgen voor de visie op de medische praktijk. Een onderzoek naar de praktische consequenties van de natuurwetenschappelijke oriêntatie in de geneeskunde zal ons een dieper inzicht verschaffen in de betekenis van de inlijving van de geneeskunde bij de natuurwetenschappen. De implicaties van de definiëring van geneeskunde als een natuurwetenschap voor het klinisch oordeel vormen het thema van deze paragraaf.

In het klinisch oordelen - het stellen van een diagnose, het formuleren van een prognose en het voorschrijven van een therapie - treedt de praktische, op het individu gerichte kant van geneeskunde aan de dag. De voorvechters van de natuurwetenschappelijke oriëntatie in de geneeskunde hielden zich ook uitdrukkelijk met dit onderwerp bezig. Met de opkomst van deze visie op de geneeskunde was, zoals in paragraaf 2.1 is aangegeven, een groeiende belangstelling 
voor de praktijk, voor het daadwerkelijk genezen, verbonden. Virchow maakte dit onmiddellijk duidelijk aan het begin van zijn bekende reeds genoemde artikel Ueber die Standpunkte in der wissenschaflichan Medicin uit 1847. Hij schreef op de eerste pagina: "Nach unserer Anschauung involvirt der Begriff der Medicin, der Heilkunde ohne Weiteres den des Heilens, obwohl es nach der neuesten Entwicklung der Medicin so scheinen kōnnte, als wenn es darauf eigentlich nicht ankäme" (Virchow, 1847, p. 1). Virchow beschouwde het genezen als de doelstelling van zowel de praktische als de wetenschappelijke geneeskunde. Hij nam daarbij nadrukkelijk afstand van de toentertijd heersende opvatting dat vanuit het gezichtspunt van de medische wetenschap het genezen er niet toe zou doen: "Mediciner kann daher nur derjenige genannt werden, der als den letzten Zweck seines Strebens das Heilen betrachtet" (ibid., p. 3). Met genezen bedoelde Virchow het instandhouden of herstellen van de normale levensvoorwaarden (vgl. ibid.). Er bestaat natuurlijk wel een feitelijk verschil tussen de praktische geneeskunde, die de werkelijke uitvoering van deze doelstelling als opgave heeft, en de wetenschappelijke geneeskunde die zich meer op het onderzoek richt. Maar de onderscheiding tussen beide was volgens Virchow niet van principiële aard. Beide beantwoorden immers aan wetenschappelijke maatstaven. De praktische geneeskunde verschilt van de wetenschappelijke, doordat de laatstgenoemde wetten voortbrengt en de eerstgenoemde niet. De praktische geneeskunde komt niet verder dan de toepassing van wetenschappelijke kennis. Maar dit doet niet af aan het wetenschappelijke karakter van de praktische geneeskunde: de medicus practícus kan zijn toepassingen wetenschappelijk verantwoorden, op basis van de resultaten van de wetenschappelijke geneeskunde.

De wetenschappelijke geneeskunde, die Virchow fundeerde op de fysiologie, bestond volgens hem niet alleen uit pathologie maar ook uit therapie: "Die wissenschaftliche Medicin ihrerseits hat zum Gegenstand die Erforschung der veränderten Bedingungen, unter denen sich der erkrankte Körper oder das einzelne leidende Organ befinden, die Feststellung der Abweichungen, welche die Lebenserscheinungen unter bestimmten Bedingungen erfahren, endlich die Auffindung der Mittel, durch welche diese abnormen Bedingungen aufzuheben sind "(ibid., p. 4).

De pathologische anatomie werd, zoals gezegd, door Virchow en de overige aanhangers van de natuurwetenschappelijke geneeskunde niet langer gezien als het toppunt van de medische wetenschap. Door de nadruk op de verzameling van anatomische gegevens vond men de pathologische anatomie te beperkt in haar opzet, ze was te statisch en daardoor machteloos. De pathologische anatomie leverde weliswaar een grote hoeveelheid feitenmateriaal, maar ze kwam niet, zoals de pathologische fysiologie, tot het formuleren van wetmatigheden omtrent het verloop van ziekteprocessen. De bovengenoemde bekende Weense onderzoeker Rokitansky trachtte dit gemis aan te vullen door zijn lokalistische 
anatomische resultaten te combineren met een synthetiserende theoretische pathologie. Deze poging werd door Virchow echter bekritiseerd en gediskwalificeerd als een terugval in de humoraal-pathologie (vgl. o.a. Ackerknecht, 1959 (1955). p. 133).

De wetenschappelijke geneeskunde bij uitstek was volgens Virchow de pathologische fysiologie, "Die Lehre von krankhaften Verrichtungen" (Virchow, 1847, p. 16). Virchow richtte in 1847 tezamen met Reinhardt het Archiv für pothologische Anatomie und Physiologie und für klinische Medizin op. In het reeds aangehaalde openingsartikel, gebaseerd op een lezing in 1846 voor de "Gesellschaft für wissenschaftliche Medicin", noemdeVirchow de pathologische fysiologie “ (...) die Veste der Medicin, an der die pathologische Anatomie und die Klinik nur Aussenwerke sind" (ibid., p. 19). De pathologische fysiologie behoort enerzijds, op grond van haar vraagstelling, tot het terrein van de geneeskunde. Anderzijds, zo stelde Virchow, voldoet ze aan de kwalificaties van de natuurwetenschap, omdat zij door haar experimentele werkwijze in staat is om wetmatigheden te formuleren. Bernard opende op vergelijkbare wijze zijn Introduction à l'étude de la médecine expérimentale met de uitspraak: "Conserver la santé et guérir les maladies: tel est le problème que la médecine a posé dès son origine et dont elle poursuit encore la solution scientifique" (Bernard, 1865, p. 5). Opvattingen van geneeskunde waarin de diagnose en prognose ver ontwikkeld zijn, maar waarin de therapie ontbreekt, werden door de aanhangers van de natuurwetenschappelijke geneeskunde bekritiseerd.

De nadruk op het genezen contrasteerde scherp, zoals we in het citaat van Virchow zien, met het therapeutisch nihilisme en scepticisme, dat in die jaren gangbaar was. Deze scepsis en onzekerheid in de geneeskunde kan worden opgevat als een reactie op eerdere ontwikkelingen in de geneeskunde. Het vroege begin van de negentiende eeuw laat een veelheid van concurrerende medische scholen zien met uiteenlopende, in de ogen van de voorstanders van een natuurwetenschappelijke geneeskunde weinig gefundeerde, opvattingen over ziekte en therapie. Deze overdaad aan opinies, die vaak berustten op een of ander wijsgerig stelsel, leidde niet alleen tot intellectuele discussies, maar ook tot sterker wordende twijfels aan de kracht van de geneeskunde (vgl. Rothschuh, 1978, p. 420). Onderzoekers die in de eerste helft van de negentiende eeuw, in oppositie tot de filosofisch getinte aanpak, een meer empirische richting insloegen, achtten de observatie van het verloop van ziekteprocessen hun voornaamste taak. Zij onthielden zich vanuit dit standpunt van ingrepen in deze processen.

De natuurwetenschappelijke geneeskunde beschouwde zich, ten opzichte van de wel empirische maar meer afwachtende, observerende opvatting van geneeskunde als een stap verder in de wetenschappelijke evolutie (vgl. o.a. Bernard, 1872, p. 566). De identificatie met de natuurwetenschappen betekende volgens Virchow dat de uitspraak "Scientia est potentia" weer in ere zou worden hersteld 
(vgl. Virchow, 1847, p. 5 e.v.). "Die wahre Wissenschaft besitzt die Fähigkeit des Kōnnens ( ....)", schreefVirchow, en van "wetenschap om de wetenschap" wilde hij in het geval van de geneeskunde niets weten (ibid., p. 7). Virchow stelde dat de wetenschappelijke geneeskunde uit twee onderdelen bestaat: "In sich setzt sie sich aus zwei integrirenden Theilen zusammen: der Pathologie, welche die Kenntniss der veränderten Bedingungen und der veränderten Erscheinungen des Lebens überliefert oder überliefern soll, und der Therapie, welche die Mittel, diese Bedingungen aufzuheben oder die normalen zu erhalten, feststellt" (ibid., p. 4). Bernard liet zich in ongeveer dezelfde bewoordingen uit toen hij stelde: "C'est cette étude physiologique et chimique des causes morbifiques qui pourra seule nous faire comprendre le mécanisme des maladies et nous indiquer les moyens qui permettront de les guérir" (Bernard, 1872 (1859/1860), p. 117). De natuurwetenschappelijk georiênteerde artsen voelden zich aangesproken door het lijden van de mens. Zij voerden dit ook aan als een der motieven om de geneeskunde op een natuurwetenschappelijke leest te schoeien. Pas door een dergelijke geneeskunde zou men de plicht om zieken en stervenden zo goed mogelijk bij te staan vervullen. Wunderlich beschreef in het laatste gedeelte van zijn werk over de geschiedenis van de geneeskunde de gesteldheid, de taak en de plichten van de "geneeskunde van den tegenwoordige tijd". De hernieuwde aandacht voor de therapie beargumenteerde hij als volgt: "Maar de geneeskunde van den tegenwoordigen tijd is zich ook meer dan ooit van hare maatschappelijke en menschlievende taak bewust. Het is haar bekend dat zij al haar weten en vermogen op een punt moet vereenigen, om namelijk het lijden der menschen, zoowel in het groote als kleine, dat ten gevolge van stoornissen in het organisme ontstaat, af te weren, te verminderen en weg te nemen" (Wunderlich, 1861 (1858), p. 292).

Karakteristiek voor de natuurwetenschappelijk georiënteerde geneeskunde is de nadruk die werd gelegd op de activiteit van de arts. De natuurwetenschappelijk geschoolde arts wachtte niet het verloop van het ziekteproces af, hij greep er, indien mogelijk en gewenst, ook in in (vgl. Helmholtz, 1903 (1877), p. 183). Bernard verklaarde dit handelend optreden tot het doel van de experimentele geneeskunde: "Le but de la médecine expérimentale, ainsi que celui de toutes les sciences expérimentales, est de parvenir au déterminisme des phénomènes afin de pouvoir agir sur eux; (....) La médecine expérimentale, en tant que science expérimentale, a un but qui se traduit par l'action. Par son essence même, elle est donc active ou pratique" (Bernard, 1957 (1865), p. 122). De experimentele geneeskunde verschilde volgens Bernard van haar voorloper, de observerende geneeskunde juist op het punt van de praktijk. Noch de zogenaamde nosologisten als T. Sydenham (1624-1689), Ph. Pinel (1745-1826) en R.Th. H. Laennec (17811826), noch de patholoog-anatomen, onder wie hij overigens ookVirchow rangschikte, bereiken het niveau van de experimentele geneeskunde, omdat zij niet 
wensen in te grijpen in de geconstateerde opeenvolging van verschijnselen. "Le médecin expérimentateur veut, non seulement connâitre la marche des maladies et leurs divers stades ou périodes, mais il veut en comprendre le mécanisme". aldus Bernard, "Il veut produire les maladies à volonté, les arrêter par l'action des modificateurs de l'organisme" (Bernard, 1957 (1865), pp. 100-101).

De empirische stellingname leidde niet langer tot een gelaten afwachten van het verloop van een ziekte. De arts heeft volgens de natuurwetenschappelijke geneeskunde juist de dure plicht om zich naar beste kunnen in te zetten voor de zieke (vgl. Helmholtz, 1903 (1877), p. 169). De geneeskunde behoefde ook niet te berusten in haar onmacht, aangezien de natuurwetenschappelijke geneeskunde concepten aanreikt die een verantwoord ingrijpen mogelijk maken. De natuurwetenschap beschikt immers over experimenteel gefundeerde wetten omtrent het menselijk functioneren. Deze kennis levert een basis voor therapeutisch handelen.

Op het gebied van de therapie keerden de natuurwetenschappelijk georiênteerde artsen zich, evenals bij het ziektebegrip, tegen opvattingen die aansloten bij het ontologische denken, zoals de leer der specifica. Deze leer, die stelde dat een bepaalde ziekte met een specifiek middel kan worden verholpen, zag ziekte te zeer als een vijandige eenheid die bestreden moet worden. Volgens de aanhangers van de natuurwetenschanneliike geneeskunde moest de theranie zich, inict niet in de eerst plaats richten op de verdrijving van ziekten, maar op het herstellen en normaliseren van de levensomstandigheden.

Voorts bracht men tegen de leer der specifica in, dat deze vorm van therapie niet is gebaseerd op wetenschappelijke kennis. Bij de legitimatie van dergelijk therapeutisch ingrijpen wordt hoogstens op de ervaring teruggegrepen. De natuurwetenschappelijke geneeskunde achtte het onbevredigend om alleen op grond van de ervaring een bepaalde behandelwijze te rechtvaardigen. In haar ogen diende de rechtvaardiging zich te baseren op natuurwetten. Het ideaal van de aanhangers van de natuurwetenschappelijke geneeskunde was een rationele therapie, gebaseerd op de kennis van de wetten van de levende natuur. "Wäre die Biologie fertig, kennten wir die Lebensgesetze und die Bedingungen ihrer Manifestation genau, wüßten wir bestimmt die Folgen jedes Wechsels dieser Bedingungen, so würden wir eine rationelle Therapie haben und die Einheit der medicinischen Wissenschaft würde hergestellt sein." (Virchow, 1849, p. 21). Zoals in de vorige paragraaf is beschreven, werd ziekte binnen de natuurwetenschappelijke geneeskunde gezien als een levensproces, dat wil zeggen: ziekte maakt deel uit van het leven. Het hele leven is, vanuit dit standpunt, wetenschappelijk te beschrijven als een door fysische en chemische wetmatigheden gecontroleerd mechanisme waarin ziekte en gezondheid variaties zijn. Het optreden van dergelijke variaties kan worden bewerkstelligd door het manipuleren van bepaalde fysische en chemische factoren: "Le traitement rationnel d'une maladie 
doit s'adresser à son mécanisme physiologique", aldus Bernard (Bernard, 1872 (1859/1860), p. 9). De door de natuurwetenschappelijke geneeskunde uitgevoerde methodische reductie van het ziek zijn tot een proces dat niet wezenlijk verschilt van andere levensprocessen en vervolgens tot een fysisch-chemisch gebeuren maakte dat verantwoord ingrijpen in het ziekteproces mogelijk werd. Diagnose, prognose én therapie zijn belangrijk, zo vonden de aanhangers van de natuurwetenschappelijke geneeskunde. Bovendien bood een geneeskunde die zichzelf ziet als natuurwetenschap ook principieel de mogelijkheden voor een wetenschappelijk gefundeerde praktijk. Klinische oordelen konden worden opgenomen binnen de wetenschap, mits ze voldeden aan de maatstaven zoals deze binnen de natuurwetenschappen gelden. De aloude tegenstelling tussen theorie en praktijk, tussen geneeskunde als wetenschap en de geneeskunst, werd in de conceptie van geneeskunde als natuurwetenschap aldus overbrugd. Het probleem van de relatie tussen theorie en praktijk, kennis en toepassing, verdwijnt binnen het kader van deze wetenschap, zo meende Van Geuns: "Het woord waarin zich hier alles oplost is: de Geneeskunde moet ene zelfstandige natuurwetenschap zijn" (Van Geuns, 1847, p. 3).

Het streven naar rationalisering en verwetenschappelijking van de medische praktijk vond uitdrukking in pogingen om de binnen de natuurwetenschappen gehanteerde rationaliteitscriteria over te nemen. Het criterium voor de geldigheid van het klinisch oordeel kon worden ontleend aan de natuurwetenschap, als men de geneeskunde als zodanig definieert. Met de karakterisering van de geneeskunde als natuurwetenschap conformeerde ook de praktische geneeskunde zich aan het natuurwetenschappelijk ideaal. De veelvuldige aanmaningen en bemoeienissen met de medische oordeelsvorming door de natuurwetenschappelijke geneeskunde laat zich verklaren uit hun wens het (natuur)wetenschappelijk niveau daarvan te verhogen.

Vanuit een natuurwetenschappelijke optiek konden de verschillende aspecten van het klinisch oordelen als volgt worden omschreven. Het stellen van een diagnose bestaat uit het opsporen van aanwijsbare afwijkende processen in het lichaam van de patiēnt. Ziektes zijn volgens de natuurwetenschappelijk georiểnteerde arts gestoorde of ontregelde materiële lichaamsfuncties. De arts schrijft een therapie voor op grond van zijn experimenteel gefundeerde natuurwetenschappelijke kennis van de wetmatigheden die het menselijk leven bepalen. De prognose krijgt derhalve het karakter van een wetenschappelijke voorspelling. Uitgaande van de toestand van de zieke en de bekende werking van het geneesmiddel kan het verdere verloop van de ziekte afgeleid worden.

Het ideaal van de natuurwetenschappelijk georiënteerde geneeskunde was een totaal inzicht in de causale samenhang van de natuurprocessen (vgl. Helmholtz, 1903 (1877), p. 170). Vanuit deze visie gaat de arts er steeds van uit dat er overal 
en voortdurend mechanische veranderingsprocessen plaatsvinden, die zich uiteindelijk in termen van kracht en materie laten beschrijven. Het leven wordt in dit verband als een causaal netwerk gezien, dat zich aan de hand van chemische en fysische wetmatigheden laat ontwarren.

Kennis van de eenvoudige of complexe oorzaken van levensprocessen, zoals van de determinanten van ziekte, vormde het doel van de natuurwetenschappelijke geneeskunde (vgl. Bernard, 1865, pp. 374 e.v.). De geneeskunde zou er dan niet langer toe veroordeeld zijn om op grond van empirische gegevens te gissen, maar kon de mechanismen beheersen. De natuurwetenschappelijke opvatting van ziekte veronderstelde dat ziekte een zich in ieder mens identiek voltrekkend proces is. Dankzij deze uniformiteit zou er ook een identieke therapie bestaan, op basis van de verworven inzichten in de fysische en chemische mechanismen die aan dat proces ten grondslag liggen. Het vooruitzicht - en het ideaal - van de natuurwetenschappelijke geneeskunde was dat door experimentele kennis van ziekte het mogelijk zou zijn om een volstrekt zekere genezing te bewerkstelligen. "On guérit toujours et sans exception quand on se place dans les conditions expérimentales connues pour atteindre ce but", aldus Bernard (Bernard, 1865 . p. 375). Het bezit van kennis van de oorzaken van levensprocessen verschaft de arts de macht om in te grijpen in geval van ziekte; ziekte wordt op basis van deze vooronderstellingen een in principe beheersbaar proces.

De natuurwetenschappelijk gevormde arts streefde ernaar om “ (...) voraus zu wissen was der Erfolg seines Eingreifens sein wird, wenn er so oder so verfährt. Um dieses Vorauswissen des Kommenden oder des noch nicht durch Beobachtung Festgestellten zu erwerben, haben wir keine andere Methode, als dass wir die Gesetze der Thatsachen durch Beobachtung kennen zu lernen suchen; (...)" (Helmholtz, 1903 (1877), p. 183). De arts moest volgens Bernard de uiteindelijke oorzaak van de ziekteverschijnselen achterhalen om therapeutisch te kunnen handelen: "Le but d'un médecin expérimentateur est de découvrir et de saisir le déterminisme initial d'une série de phénomènes morbides obscurs et complexes; il dominera ainsi tous les phénomènes secondaires; (...) et pour guérir, c'est toujours finalemant au déterminisme intial des phénomènes qu'il faut remonter" (Bernard, 1865, pp. 377-379).

In Bernards redenering kan men de eerder beschreven, als ontologisch gekenschetste gedachte dat ziekte een specifiek en reēel bestaand proces zou zijn, zien terugkeren. Hij brengt hier ziekte in verband met een specifieke oorzaak, een begrip met een ontologische connotatie. Bernard gaat er klaarblijkelijk van uit dat er een specifieke en reconstrueerbare causale keten loopt van een feitelijke, oorspronkelijke oorzaak van de ziekte tot aan het door de patiënt gepresenteerde beeld. Bovendien fundeert hij zijn therapie op deze specifieke oorzaak. Deze redenering vertoont opmerkelijke overeenkomsten met het onder anderen door 
Virchow gehekelde ontologische concept van de specifieke therapie. Weliswaar was genezen bij Bernard een activiteit die stoelt op experimentele wetenschappelijke kennis en niet louter op de ervaring. Maar aan de andere kant bestond genezen volgens hem uit het bestrijden van bepaalde oorspronkelijke ziekteoorzaak en niet uit het veranderen van levensomstandigheden. De conclusie moet wel luiden dat, terwijl de natuurwetenschappelijke artsen hun best deden om het ontologisch denken te vermijden en om daar tegenover een functioneel begrip van ziekte te doen gelden, het ontologisch ziektebegrip toch vaak weer binnensloop in het denken over de geneeskunde. Doordat hij hechtte aan aanschouwelijkheid en toetsbaarheid gebaseerd op empirisch waarneembare gegevens, hadVirchow zich niet helemaal kunnen losmaken van het ontologisch ziektebegrip. Bernard omarmde een ontologisch getinte opvatting van een oorspronkelijke ziekte-oorzaak. Mede ten gevolge van de ontdekkingen in de bacteriologie, traden in de jaren tachtig van de negentiende eeuw ontologische opvattingen wederom sterk op de voorgrond en bleef men balanceren op de rand van een ontologisch ziektebegrip. Sommigen, zoals Virchow, laakten ook toen het te sterk ontologische karakter van dit ziektebegrip en de ermee verbonden leer van specifieke geneeswijzen.

De natuurwetenschappelijke opvatting van de geneeskunde extrapoleerde de in de natuurwetenschappen gehanteerde visie op de dode natuur naar de levende natuur en daarmee naar de mens. Van de mens komt binnen het kader van de natuurwetenschappelijke geneeskunde immers uitsluitend de lichamelijkheid ter sprake en dit lichamelijk functioneren werd gelijk gesteld aan het functioneren in de levende natuur. De experimentele natuurwetenschappelijke methoden werden van toepassing geacht op alle levende wezens, waaronder ook de mens. Ten aanzien van het klinisch oordeel had dit tot gevolg dat de in de natuurwetenschappen gangbare wijze van verklaren werd overgenomen. Medische kennis bestond, vanuit de natuurwetenschappelijke optiek, uit universele uitspraken die een uniform causaal verband vastleggen tussen verschillende empirische verschijnselen. Wil de arts een diagnose stellen, dan dient hij empirische gegevens te verzamelen die relevant zijn met betrekking tot de verschijnselen die de patiënt vertoont. Om vervolgens een prognose op te stellen kan de arts op grond van zijn gegevens over de individuele patiënt en van zijn kennis van de medische wetten een verloop voorspellen. Op dezelfde wijze kan hij de invloed van een bepaalde behandelwijze of een geneesmiddel op het ziekteproces vooraf bepalen. De combinatie van individuele gegevens met de bekende medische wetmatigheden levert een klinisch oordeel op dat qua structuur correspondeert met het verklaringsmodel binnen de natuurwetenschappen (vgl. o.a. Rothschuh, 1968a). 
Het nieuwe wetenschappelijke aanzien van het klinisch oordeel deed nogal wat stof opwaaien onder de geneeskundigen in de negentiende eeuw. Enerzijds wilde men het wetenschappelijk karakter van het klinisch oordeel in de praktijk sterker naar voren doen komen. De bezorgdheid gold in dit geval vooral de vergroting van het wetenschappelijk gehalte van het klinisch oordeel. Het klinisch oordeel dat zich baseert op ervaring aan het ziekbed moest in dit geval wijken voor een wetenschappelijk gefundeerde praktijk. De opleidingen dienden de arts vooral de benodigde wetenschappelijke kennis bij te brengen. Het streven naar wetenschappelijkheid uitte zich ook in het streven naar scholing van artsen in een correcte wetenschappelijke houding tegenover de patiënt. Zo bepleitte men bijvoorbeeld om het klinisch oordeel te rationaliseren door de empirische waarneming te standaardiseren.

Anderzijds werd in diverse, soms heftige en geêngageerde, publicaties getwijfeld aan de praktische toepasbaarheid van het wetenschappelijk instrumentarium en aan de aanvaardbaarheid van een wetenschappelijke houding ten opzichte van de patiënt. In deze beschouwingen, die zich verzetten tegen het wetenschappelijk karakter van het klinisch oordeel, treffen we een combinatie aan van verontrusting en verontwaardiging over de recente ontwikkelingen en scepsis met betrekking tot de almacht en alleenheerschappij van de natuurwetenschap. Verontrust was men omdat de wetenschappelijke houding aan het ziekbed wordt gewantrouwd. De verontwaardiging kwam voort uit de vrees voor ouderwets en irrationeel gehouden te worden. De twijfel en scepsis golden de vraag of de geneeskundige praktijk uitsluitend kan worden gebaseerd op natuurwetenschappelijke kennis. Is aan het ziekbed niet juist of ook klinische ervaring essentieel? In dit verband werden het primaat van de klinische ervaring en de klinische blik benadrukt.

Een karakteristiek voorbeeld van het verzet tegen de exclusieve aanspraak op rationaliteit in het klinisch oordeel van de natuurwetenschappelijke geneeskunde is te vinden in een ingezonden stuk in het Nederlandsch Tijdschrift voor Geneeskunde, getiteld "Onze richting in ons handelen aan het ziektebed" door I. Leonides van Praag (Leonides van Praag, 1866, p. 263 e.v.). De schrijver verdedigde daarin de waarde van "de eeuwenoude waarneming aan het ziektebed" tegenover de pretenties van de natuurwetenschappelijke geneeskunde. Hij verklaarde niet tegen de moderne geneeskunde te zijn: "De utopie eener geneeskunst, gegrondvest op physiologisch-anatomische wetten, is zeer schoon en stellig onzer aller vurigste wensch, maar die kan voor als nog niet als maatstaf van ons handelen aan het ziekbed gelden. (...) wij, die ons met de werkelijkheid moeten bezighouden, wij gelooven nog niet aan die utopie" (ibid., p. 264). Zijn op klinische ervaring gebaseerde handelen was, naar zijn mening, echter niet minder rationeel dan dat van de natuurwetenschappelijke arts. "Ervaring aan het ziekbed is niet alleen ook nuttig, maar is allereerst noodig om zieken te kunnen behandelen. 
Wij ontkennen ten eenenmale, dat de kennis die de Geneesheer aan het ziekbed opdoet, zich tot een zeker 'savoir faire' beperkt, wanneer die kennis niet in verband gebragt wordt met Physiologie. (...) nooit zal ik mij daartoe laten verleiden, de bron van al mijn weten in Anatomie, Physiologie en Pathologie te zoeken", aldus Leonidas van Praag (ibid., p. 265). De wetenschap vormde volgens hem een waardevol middel bij de behandeling van de zieken. Maar in het klinisch oordeel was ook het gebruik van andere bronnen van kennis, zoals klinische ervaring, gerechtvaardigd. Leonides van Praag keerde zich dus vooral op praktische gronden tegen de natuurwetenschappelijke geneeskunde, maar gaf tegelijk aan dat wetenschappelijke kennis aan het ziekbed nooit voldoende zal zijn. Fen rechtvaardiging van het rationele karakter van die andere kennis, van de eeuwenoude ervaring, of een analyse van de eigen aard van medische kennis tegenover (natuur)wetenschappelijke kennis, ontbrak evenwel in zijn betoog. Beide onderscheiden posities keren regelmatig terug in de discussies rond het klinisch oordeel. Nu eens stond de aard van de medische kennis als zodanig in het middelpunt, waarbij de waarde van de klinische ervaring en de klinische blik werd benadrukt. Het verschil van mening betrof dan het al of niet natuurwetenschappelijke karakter van de geneeskunde en van het klinisch oordeel in het bijzonder. Dan weer werd het natuurwetenschappelijke karakter van de medische kennis ongemoeid gelaten en vroeg men zich af hoe deze kennis in het klinisch oordeel op wetenschappelijk én ethisch verantwoorde wijze moet worden toegepast.

Sommigen, bijvoorbeeld de eerdergenoemde Amsterdamse hoogleraar Van Geuns, namen een wat genuanceerd standpunt in. Van Geuns toonde zich enerzijds een voorstander van de natuurwetenschappelijke conceptie van de geneeskunde. Anderzijds erkende hij dat een dergelijke vorm van geneeskunde aan het ziekbed lacunes vertoont. De praktische geneeskunde behoefde zijns inziens niet te worden gereduceerd tot pathologische fysiologie, er was daarnaast nog ruimte voor een algemene ziekteleer. In deze algemene ziekteleer vinden begrippen die niet passen binnen de geneeskunde als natuurstudie een plaats. Bijvoorbeeld het onderscheid tussen gezond en ziek, dat in de natuurwetenschap geen betekenis heeft, is onmisbaar in de praktijk. De algemene ziekteleer en de pathologische fysiologie dienden beide echter wel beoefend te worden volgens dezelfde principes. Beide gaan uit van: "(...) empirische nasporing, van de objectieve waarneming, van de kennis van het gegevene", aldus Van Geuns (Van Geuns, 1857. p. 255). De algemene ziekteleer moest ervoor waken in de dwalingen van overijlde systeembouw te geraken en ze diende haar karakter van empirische wetenschap niet overboord te zetten. Maar Van Geuns was wel overtuigd van haar bestaansrecht als wetenschappelijke verantwoording van het handelen aan het ziekbed (vgl. Van Geuns, 1857, p. 247 e.v.). 
In deze paragraaf is geschetst hoe de natuurwetenschappelijke opvatting van het klinisch oordeel tot stand is gekomen. Aangegeven is hoe volgens de natuurwetenschappelijk georiënteerde geneeskunde het klinisch oordeel inpasbaar is in de natuurwetenschap. Dit oordeel neemt dan het karakter aan van een causale verklaring en/of voorspelling. De specifieke gegevens van het lichamelijk functioneren van het individu worden door de arts gecombineerd met bepaalde algemene fysische en chemische wetmatigheden betreffende levensprocessen. Vervolgens deduceert de arts daaruit zijn conclusies; hij formuleert een wetenschappelijk verantwoorde diagnose. Omdat de arts naast kennis omtrent het lichamelijk functioneren ook kennis bezit van de uitwerking van externe factoren daarop, kan hij tevens op wetenschappelijke gronden een therapie voorschrijven en mede aan de hand daarvan tot een prognose komen.

Met deze schets van het klinisch oordeel is het algemene beeld van de uitgangspunten van de negentiende-eeuwse natuurwetenschappelijk georiënteerde geneeskunde afgerond. Deze schets van de natuurwetenschappelijke geneeskunde wordt afgesloten met de bespreking van de ideeēn van twee vooraanstaande Nederlandse representanten daarvan: Ramaer en Donders.

\subsection{Johannes Nicolaas Ramaer (1817-1887)}

De keuze van Ramaer en Donders als gezichtsbepalende medici ten tijde van de natuurwetenschappelijk georiënteerde geneeskunde in de negentiende eeuw ligt voor de hand. Beiden genoten immers niet alleen in hun eigen tijd een hoog aanzien, maar worden ook in onze tijd algemeen geëerd en gewaardeerd. Zij hebben de geneeskunde in Nederland in de tweede helft van de vorige eeuw diepgaand beinvloed en hebben hun opvattingen omtrent de geneeskunde ruimschoots in geschrifte naar voren gebracht. Illustratief is ook dat J. en A. Romein de laatstgenoemde, Donders, in hun gelijknamige boek hebben besproken als één der "erflaters van onze beschaving" (Romein, 1956 (1938-1940), p. 677 e.v.).

Rond 1850 vertoonde de geneeskunde in Nederland een rommelig beeld. Er bestond een grote verscheidenheid in bevoegdheden voor het uitoefenen van de medische praktijk. Op de hoogste trap stonden degenen die de graad "doctor medicinae" bezaten. Daarop volgden de graden "doctor chirurgiae" en "doctor artis obstetricae". Tevens waren er nog heelmeesters, vroedmeesters en -vrouwen voor steden en ten plattelande, oogmeesters en officieren van gezondheid. De universitaire medische opleidingen vertoonden een wisselend gehalte. Van een algemeen gedeelde, wetenschappelijk gefundeerde en systematische visie op de beoefening van de geneeskunde was in de eerste helft van de negentiende 
eeuw nog geen sprake (Vgl. Festen, 1974, pp. 39-40). Ramaer en Donders hebben beiden in belangrijke mate bijgedragen aan de eenwording en statusverbetering van de geneeskunde in Nederland.

Johannes Nicolaas Ramaer werd geboren op 20 april 1817. Hij studeerde geneeskunde te Utrecht en Groningen. Daarna zette hij zijn studies voort in het buitenland, onder andere bij Rokitansky en Skoda te Wenen. Ramaer is in 1839 gepromoveerd. Nog zeer jong, in 1841, werd hij benoemd tot eerste geneesheer aan het "Provinciaal Krankzinnigenhuis" te Zutphen. In 1863 is hij geneesheerdirecteur van het krankzinnigengesticht te Delft geworden. In 1869 werd hij op zijn verzoek eervol ontslagen maar hij bleef wel als consulterend geneesheer aan de Delftse instelling verbonden. In 1872 aanvaardde Ramaer de functie van geneeskundig inspecteur der gestichten voor krankzinnigen. Hij is op 2 november 1887 overleden.

Als medicus wijdde Ramaer zich uitsluitend aan de psychiatrie. In zijn publicaties hield hij zich echter niet alleen met de psychiatrie bezig maar ook, evenals de door hem bewonderde Griesinger, met de geneeskunde in het algemeen. Zijn geschriften getuigen van een grote interesse voor theoretische discussies omtrent de wetenschappelijke status van de geneeskunde en de psychiatrie in het bijzonder. Daarnaast schuwde hij praktische onderwerpen, waarbij de verworvenheden van de natuurwetenschappelijke benaderingswijze worden uiteengezet, en casuïstische studies niet (vgl. o.a. Ramaer, 1841). In zijn artikelen toonde Ramaer zich een voorstander van de natuurwetenschappelijke oriëntatie in de geneeskunde. Daarbij trad zijn affiniteit met andere, met name buitenlandse, natuurwetenschappelijke geneeskundigen aan de dag. Hij was goed op de hoogte van de ontwikkelingen in de psychiatrie en van de vernieuwingen binnen de geneeskunde, zowel in Nederland als de rest van Europa. Ramaers opvattingen zijn sterk beïnvloed door Griesinger, Roser en Wunderlich, de belangrijkste vertegenwoordigers van de Tübinger school. Deze Duitse artsen publiceerden hun ideeën over een fysiologische natuurwetenschappelijke geneeskunde in hun eerdergenoemde, in 1842 opgerichte tijdschrift Archiv für physiologische Heilkunde. Maar in zijn publicaties citeerde Ramaer ook met regelmaat artikelen van bijvoorbeeld Virchow.

Ramaer is overigens niet alleen als geneeskundig inspecteur van de krankzinnigengestichten en als theoreticus belangrijk geweest voor de Nederlandse geneeskunde. Hij heeft zich ook met kracht ingezet voor de organisatie van de Nederlandse geneeskundigen. Zo vormde hij te Zutphen een bestaand leesgezelschap om in een vereniging, de Zutphense Geneeskundige Kring, "ten doel hebbend de bevordering van het vriendschappelijk verkeer tusschen de geneeskundigen der stad Zutphen en haren omtrek en de aankweeking van derzelver 
wetenschappelijke werkdadigheid". Naast het vriendschappelijk verkeer en de wetenschappelijke scholing wilde deze kring ook het aanzien van de medische stand verbeteren en invloed uitoefenen op de geneeskundige wetgeving. Elders in het land ontstonden in de jaren veertig van de negentiende eeuw eveneens dergelijke lokale genootschappen. Ramaer spande zich echter ook in voor een landelijke organisatie. Zo geldt hij als stichter van de Nederlandsche Maatschappij tot bevordering der Geneeskunst, die in 1849 is opgericht (vgl. Festen, 1974, p. 85), In 1858, in 1868 en in 1874 was hij voorzitter van deze Maatschappij. Ramaer was tevens een der oprichters en de eerste voorzitter van de Nederlandse Vereniging voor Psychiatrie in 1873.

Ramaer heeft op vele fronten naar de emancipatie van de geneeskunde gestreefd. Hij wilde hiermee de erkenning en de waardigheid van de geneeskunde in de ogen van het publiek verbeteren. Dit trachtte hij te bewerkstelligen door enerzijds het wetenschappelijk niveau van de geneeskunde zeker te stellen en anderzijds de medische beroepsgroep te organiseren, bijvoorbeeld door een onderscheid te bepleiten tussen bevoegde en onbevoegde beoefenaren van de geneeskunst. Ramaers bemoeienissen met het wetenschappelijk aanzien van de geneeskunde en met een wetenschappelijk gefundeerde geneeskundige praktijk maken het begrijpelijk dat hij zich veelvuldig heeft beziggehouden met theoretische vraagstukken binnen de geneeskunde. Daarbij beperkte hij, zoals gezegd, zijn blik niet tot de psychiatrie, maar ontwikkelde hij ideeën betreffende de geneeskunde als geheel. In deze paragraaf zullen eerst Ramaers algemene opvattingen over de geneeskunde worden gepresenteerd en vervolgens zijn ideeēn over psychiatrie.

Ramaer was ervan overtuigd dat de geneeskunde gerangschikt mag worden onder de stellige wetenschappen. Met deze term doelde Ramaer op de empirische natuurwetenschappen: "Inderdaad, elke kennis, die haren grondslag in de natuur heeft, is stellig, en zonder dien grondslag is de geneeskunde niet te denken" (Ramaer, 1851 a, p. 3). De geneeskunde komt deze plaats toe, zo schreef hij verder, omdat zij het enige kenmerk draagt van de stellige wetenschap: "(...) hetwelk bestaat in de bekendheid der wetten, welke haar onderwerp regeren" (ibid.. p. 15). Het streven naar kennis van wetmatigheden vormde zijns inziens de kern van het geneeskundig onderzoek.

Ramaer was zelfs van mening dat, als men de geschiedenis van de geneeskunde bestudeerde, men ook al in de tijd dat de geneeskunde zich nog niet als een samenhangende tak van wetenschap had geformeerd de stellige richting in de geneeskunde kon aantreffen. Toentertijd werden immers verschijnselen en geneesmiddelen al met elkaar in verband gebracht op grond van de ervaring. aldus Ramaer. En voor degene die deze ervaring bezit, heeft dit al de waarde van stellige kennis (vgl. ibid., p. 4). 
Evenals de andere aanhangers van de natuurwetenschappelijke geneeskunde wees Ramaer een vermenging van metafysische standpunten met wetenschap af. In zijn bespiegelingen over de geneeskunde nam hij een strikt methodologisch materialistisch standpunt in. Van vitalistische principes als levenskracht wilde hij dan ook niets weten. Bij de onderkenning van ziekten moesten zijns inziens de fysische wetten worden toegepast. In de geneeskunde zoekt men naar verklaringen in termen van stof en kracht, aldus Ramaer (vgl. ibid., pp. 8 e.v.). Ramaer stelde ook al eerder, met klem: "De opvatting levenskracht is regtstrecks strijdig met het begrip kracht" (Ramaer, 1844a, p. 14). Het begrip "levenskracht" leidde misschien wel tot aanlokkelijke speculaties, maar het maakt de levensverschijnselen niet begrijpelijker en het hoort dus zeker niet in de wetenschap thuis. Integendeel, zo stelt hij: "Het begrip levenskracht brengt duisternis en verwarring in de leer des levens" (ibid., p. 25). Dit begrip werkt in de fysiologie dan ook alleen maar schadelijk. Ramaer concludeerde: "Kan het leven derhalve niet gehouden worden voor de uiting van eene bijzondere kracht, noch ook beschouwd worden als gevolg van het zamenkomen der algemeene natuurkrachten met eene eigenaardige kracht, - dan moet het een uitvloeisel zijn van de algemeene krachten der stof, (...) Er bestaat geene scheikundige werking, welke niet bepaalde omstandigheden tot hare opwekking behoeft en de organische verbindingen zijn evenzeer als de anorganische aan die wet onderworpen. Leven is derhalve het gevolg der bewerktuiging en bewerktuiging is de kristallisatie der organische verbindingen" (ibid., pp. 2829). Deze bepaling van wat "leven" is klinkt menigeen wellicht vreemd in de oren, zo merkte Ramaer op, maar een dergelijke bepaling voldoet aan de behoeften van het verstand dat naar een verklaring zoekt van de levensverschijnselen. Willen we wetenschap bedrijven, dan moeten we het leven vanuit deze materialistische optiek beschouwen (vgl. ibid., p. VI en p. 30).

Het was onterecht, aldus Ramaer, om de opvatting van de geneeskunde als "stellige wetenschap" als een utopie te kwalificeren. De mogelijke tegenwerping tegen een dergelijke karakterisering van de geneeskunde, luidend dat vooral wat betreft het genezen en de kennis over geneesmiddelen de opbrengsten van de natuurwetenschappelijke richting in de geneeskunde gering zijn, pareerde Ramaer met de opmerking dat het slechts een kwestie van tijd is voordat dit probleem is opgelost. De ontwikkeling van een wetenschap der genezing volgt met een langzamere tred (vgl. Ramaer, 1851 a, pp. 12 e.v.). Ramaer erkende dat de kennis van de wetten op verschillende terreinen van de geneeskunde nog onvolkomen was, maar dat was zijns inziens geen onoverkomelijk bezwaar. Ook aan andere "stellige" wetenschappen zou men immers niet het predikaat exacte wetenschap onthouden, op grond van het feit dat ze nog niet alles hebben ontdekt wat er te ontdekken valt. Om een wetenschap "stellig" te kunnen noemen moet een bepaald soort wetmatigheden bekend zijn: "De wetten, op grond waarvan de 
onderzoekingen konden geschieden, welke tot die ontdekkingen moesten leiden (...)" (ibid., p. 27). In de geneeskunde zijn dergelijke wetten, "op grond waarvan elke arbeid in de geneeskunde ondernomen kan worden", net zomin in het duister als in de andere wetenschappen, aldus Ramaer (vgl. ibid.).

Ramaer erkende dat op het gebied van het genezen de vruchten van de "nieuwere rigting" het schraalst zijn. Dit gebrek relativeerde hij echter als volgt. Aan de ene kant konden de empirisch gefundeerde geneeswijzen en geneesmiddelen uit het verleden ook door de aanhanger van de stellige richting worden toegepast, aangezien de geneeskunde als stellige wetenschap immers voortbouwde op de eeuwenoude ervaring. De natuurwetenschappelijk gevormde geneesheer bezat daarbij overigens wel een beter inzicht in de werking van de geneesmiddelen dan men vroeger had. Aan de andere kant was, volgens Ramaer, de kennis van de werking der geneesmiddelen op zich niet zo belangrijk als andere vormen van kennis die de geneeskunde al wel bezat, te weten de wetmatige kennis op grond waarvan therapie mogelijk is. Ramaer formuleerde zijn standpunt aldus: "(...) doch meer dan door de naauwkeurige kennis van de werking der geneesmiddelen en meer dan zij immer daardoor winnen zal, heeft de therapie gewonnen door de meerdere ontwikkeling der pathologie en diagnostiek, want die zijn het, welke ons geleerd hebben, wanneer wij van de ziekteprocessen, waarvan wij de verschijnselen gadeslaan, genezing kunnen te gemoet zien, en wanneer het met alle wetenschap strijdt, genezing te verwachten; ja, nog meer, wanneer en op welke wijze wij door ontijdige aanwending der ons ten dienste staande middelen het ziektebeloop schadelijk zouden storen,- die zijn het derhalve, welke den therapeut een rationelen grondslag voor zijn handelen verschaffen" (ibid., p. 15).

In 1844 besprak Ramaer instemmend de opvattingen van Wunderlich en Roser, de uitgevers van het Archiv für physiologische Heilkunde. Zij hadden, zijns inziens terecht, enkele jaren tevoren allerlei resterende dwalingen uit de geschiedenis van de geneeskunde aan de kaak gesteld. Ramaer schaart zich achter hun opvattingen die hij als volgt omschreef: "De grondregels, van welke zij in hun onderzoek uitgaan, zijn deze: de ziektekunde moet in de levensleer wortelen; in haar ligt de geheele toekomst der Geneeskunde; zij leert de wetten, volgens welke het organismus leeft en ziek wordt, geneest en sterft; iedere wet, welke vastgesteld wordt, moet hare bewijzen met zich brengen, grondige bewijzen, die niemand kan wegredeneren, van al de daadzaken, waarnemingen en proeven te hunner bevestiging begeleid; uit de bestaande bouwstoffen moet derhalve eene stellige wetenschap worden ontwikkeld, welke niet op gezag, maar op empirische bewijzen, rust, welke de verschijnselen, die haar voorkomen, verklaart en begrijpt, en evenzeer den beoefenaar bewaart voor de begoochelingen der praktijk, als aanleiding geeft tot het ontstaan eener therapie, die reden geeft van haar 
handelen en eenen genoegzamen graad van zekerheid bezit. Uit volle overtuiging hecht ik mij aan deze beginselen, en van harte juich ik ze toe, want zonder dezelve is de geneeskundige wetenschap eene ijdele pralerij van ledige woorden, met haar, al wat men zich ooit schoons van haar hebbe gedroomd; (...)" (Ramaer, 1844b, p. 73). Evenals Roser en Wunderlich was Ramaer van mening dat de basis voor de geneeskunde wordt gevormd door de levensleer, de fysiologie.

Ramaer lichtte zijn opvatting van de geneeskunde als stellige wetenschap nader toe door de wetten waarnaar de geneeskunde streeft, als volgt te omschrijven. De eerste wet, die zijns inziens het onderwerp van de geneeskunde vormt, was de "wet des levens". Deze luidde: "(...) wij kennen geen leven zonder organisatie, - geene organisatie zonder beweeging, - geene beweeging zonder terugwerking. Niet anders is het met het leven van den mensch; ..." (Ramaer, 1851a, p. 15). Ramaers tweede wet was: "Elke wijziging in den toestand des ligchaams openbaart zich door evenredige uitingen des levens" (ibid., p. 16). De derde wet werd als volgt geformuleerd: "De toestanden, welke door snelle of langdurige inwerking van ongewone invloeden in het ligchaam ontstaan zijn, ondergaan, onder de invloed der gewone levensvoorwaarden, eene reeks van vormveranderingen (ziekteprocessen), welke òf in gezondheid eindigen, ò op een voor het individu onschadelijk standpunt terugblijven, ò tot ontbinding van het individu voeren" (ibid., p. 18). De vierde wet sloot hier op aan en luidde: "De uiterlijke levensvoorwaarden kunnen zoodanig geregeld worden, dat de eerstgenoemde ziekteprocessen (die, welke genezing doen verwachten) worden verkort, de laatstgenoemde (die welke in ontbinding van het individu uitloopen) in hun verloop een wijziging ondergaan, welke hen in (volkomene of betrekkelijke) gezondheid doet eindigen" (ibid., p. 20).

Verschillende aspecten van Ramaers wetenschapsconcept treden in deze wetten aan de dag. De omschrijving van de eerste wet maakt in de eerste plaats duidelijk dat Ramaer de mens in de geneeskunde wilde beschouwen als een onderdeel van de levende natuur. Dat wil zeggen, in de geneeskunde wordt de mens gezien als een levend organisme, wiens leven, ziek zijn en sterven zich voltrekt volgens de wetten van de fysiologie (vgl. ook de eerder geciteerde passage van Ramaer; Ramaer, 1844b, p. 73).

In de formulering van de eerste wet als de "wet des levens" bleek wederom Ramaers verwantschap met de Tübinger School. Het toppunt van het geneeskundig weten wordt, zoals hij zei: "(...) door den veelomvattenden naam van physiologische geneeskunde het best (...) uitgedrukt" (Ramaer, 1851a, p. 16.). Ramaer gaf aan dat de pathologie en de fysiologie hand in hand zouden moeten gaan om de wetten des levens te ontrafelen. De pathologische anatomie had volgens hem niet langer het laatste woord in de geneeskunde. Ook elders benadrukte 
Ramaer dat: “(...) wanneer men met levenden, die ziek zijn, te doen heeft, het voornamelijk op pathologische physiologie aankomt, van welke de pathologische anatomie slechts hulpwetenschap is" (Ramaer, 1857, p. 114). Pathologisch-fysiologische kennis gaf zijns inziens beter rekenschap van de wijzigingen die in de verrichtingen der organen onder de invloed van de ziekte zijn ontstaan, dan de pathologische anatomie.

Ramaer maakte, evenals de eerder besproken natuurwetenschappelijke geneeskundigen, geen principieel onderscheid tussen ziekte en gezondheid. In de toelichting bij de eerste wet schreef hij: "Deze wet leert gezondheid en ziekte begrijpen als toestanden, welke niet van elkander afgescheiden zijn, maar, - omdat zij openbaringen zijn van hetzelfde leven, waarvan het verschil zijnen grond heeft in verandering der uiterlijke levensvoorwaarden, - langs duizende wegen onmerkbaar in elkander overgaan en dan eerst als verschillend zich openbaren, wanneer de overgang snel was of de ontwikkeling in de nieuw ontstane rigting eenen graad bereikt heeft, die het onderscheid duidelijk in het oog doet vallen" (Ramaer, 1851a, p. 16). Ziek en gezond verschillen dus slechts gradueel en de fysiologie is in staat om de betreffende levensuitingen verklaren. Met Virchow en de overige natuurwetenschappelijke geneeskundigen was Ramaer van mening dat ziekte begrepen moest worden als een vorm van leven, als leven onder afwijkende omstandigheden. Daarom knn de fysiolngie, die als stellige wetenschap de wetten des levens formuleert, ook de basis vormen van de geneeskunde. Ramaer stelde in dit verband met kracht: "Alle gevallen, (...), die in het gezonde en zieke leven kunnen voorkomen zijn tot deze wetten terug te brengen, zij zijn het derhalve, die de beginselen, die de grondwet der geneeskundige wetenschap vormen, die den grondslag van elk bewust geneeskundig handelen uitmaken" (ibid., p. 23).

In de tweede en de derde wet gaf Ramaer, volgens eigen zeggen, zijn visie op de diagnostiek en de therapie. De formulering van deze wetten levert tevens verdere aanknopingspunten voor het ziektebegrip dat Ramaer hanteerde. Elke afwijkende lichamelijke toestand was volgens Ramaer verbonden met afwijkend functioneren. Hij gebruikte hier met instemming een voorbeeld van Henle betreffende de diagnose bij schele hoofdpijn. "Voor den physiologischen arts echter betekent schele hoofdpijn, zoo als Henle doet opmerken, niets anders dan dat de ééne $\mathrm{N}$. supra-orbitalis in eenen ongewone toestand verkeert; in hoeverre die toestand met andere te gelijker tijd aanwezige verschijnselen in verband kan staan, blijft dan het onderwerp van verder onderzoek" (ibid., p. 17). In de derde wet worden nogmaals de vormveranderingen gerelateerd aan het lichamelijk functioneren. Deze samenhang was voor Ramaer belangrijk, omdat zijns inziens de kennis der ziekteprocessen niet alleen de prognose bepaalt, maar in de eerste plaats de grondslag van de behandeling uitmaakt (vgl. ibid., p. 18). 
Het afwijkende lichamelijk functioneren werd door Ramaer niet gezien als het gevolg van een strijd tussen het leven en een binnengedrongen parasiet. Dit zou een ontologisch ziektebegrip impliceren en daar zette Ramaer zich nadrukkelijk tegen af. Hij verweet de natuurhistorische school dat zij, hoewel zij door een meer fysiologische benadering wel een stap in de goede richting van de zekerheid in de geneeskunde heeft gezet, toch een gebrek heeft. Dat gebrek, waardoor in principe alles weer wordt vernietigd, was de ontologie (vgl. Ramaer, 1844 b, p. 61). Als de moderne geneeskunde zich daarentegen zou baseren op de empirische fysiologie en de ontologie werd verworpen, was de geneeskunde op het rechte pad, volgens Ramaer. In de geschiedenis is de geneeskunde telkens ten prooi geraakt aan een of ander stelsel. De ontologie heeft daar in verschillende gedaanten het hare toe bijgedragen. Maar, zo concludeert Ramaer optimistisch, " (...) zeker is het, dat, door de nederlaag der ontologie, der Geneeskunde een nieuw tijdvak geopend is, dat evenzeer der wetenschap vruchtbaar als der menschheid heilrijk belooft te zijn" (ibid., p. 76).

Ramaers afkeer van ontologische concepties van ziekte blijkt duidelijk uit zijn afwijzing van het begrip "ontsteking", dat zijns inziens van ontologische aard is. In 1850 besteedde hij in een artikel getiteld "Anatomico-pathologische aanteekeningen, de hersenen en hare bekleedselen betreffende. 1. Over ecchymoses subarachnoideae", in het Tijdschrift der Nederlandsche Maatschappij tot Bevordering der Geneeskunst, vele pagina's aan een uitwijding over dit begrip. Hij beschreef hoe het begrip ontsteking als aanduiding voor een specifieke toestand had standgehouden. Dat was opmerkelijk, aldus Ramaer, omdat in de recente geneeskunde dergelijke ontologische begrippen hun gelding verloren. In de geschiedenis was veel gediscussieerd over de meest karakteristieke kenmerken van ontsteking, die van oudsher werden beschreven als roodheid, zwelling, koorts en pijn. Met de neergang van de ontologie zou men verwachten, zo meende hij, dat er aan de twist over het kenmerkende criterium voor ontsteking een eind gekomen was. Maar nee, zelfs de microscoop was ingezet om de ontologie van de ontstekingen te ondersteunen, zo schreef hij (vgl. Ramaer, 1850, p. 80). Met betrekking tot het begrip ontsteking concludeerde Ramaer: "De ontsteking als zo0danig mist dus elk bepaald kenmerk. En hoe kan het ook anders? Door beeldspraak in het leven geroepen heeft het woord nooit iets anders dan theorien kunnen vertegenwoordigen, de ontologie ten allen tijde bevorderd en nimmer het begrip van iets werkelijks kunnen omvatten." (ibid., p. 86).

In 1851 wijdde Ramaer zelfs een geheel artikel getiteld "Over de verwerping van het begrip ontsteking", in hetzelfde Tijdschrift der Nederlandsche Maatschappij tot Bevordering der Geneeskunst, aan dit onderwerp. In oppositie tot Donders, in wiens ogen het begrip ontsteking een proces aanduidde waardoor het een niet te 
ontologische notie zou zijn, verklaarde Ramaer nadrukkelijk dat het begrip ontsteking als ziektebenaming diende te worden geschrapt, aangezien het een ontologisch begrip was. Ontologie noemde Ramaer een hoofdzonde van een verouderde pathologie, waarvan velen zich in de moderne geneeskunde niet goed hadden kunnen bevrijden. Dat men een beetje ontologie toeliet, werd door Ramaer streng afgekeurd. Hij beschouwde het als de: "(...)verkrachting van het beginsel, waarop de wetenschappelijke geneeskunde berust (...)" (Ramaer, $1851 \mathrm{lb}$, p. 145). Hij onderschreef de mening van Roser en Wunderlich dat de ontologie op geneeskundig vlak de voornaamste en meest wezenlijke dwaling is, een dwaling die de vooruitgang van de wetenschap in de weg staat (vgl. ibid., p. 145). Ramaers afkeer van ontologische concepties van ziekte blijkt daarnaast ook uit zijn voortdurende speurtocht naar het afwijkend functioneren dat de oorzaak van geestesziekten kan zijn (Ramaer, 1857, pp. 114 e.v.; Ter Meulen \& Widdershoven-Heerding, 1985, p. 114).

Hoewel hij zich sterk verzette tegen ontologisch denken in de geneeskunde verraadt Ramaers opvatting niettemin bepaalde ontologische aspecten. Evenals Bernard en Virchow wist hij zich niet geheel los te maken van ontologische noties. De ontologie die hij bestreed, de geneeskundige ontologie, definieerde Ramaer als: "(...) die werking van het verstand, welke een geheel schept van ziekteverschijnselen, ziekteproducten of ziektetoestanden, die niet noodzakelijk bijeen behooren, en zulke vereenigingen als werkelijke wezens (onta) aanmerkt en behandelt" (Ramaer, 1851b, p. 146). Ideeën leiden zijns inziens welhaast onafwendbaar tot rëificatie, tot ontologie. Ramaer baseerde zijn verwerping van het begrip ontsteking onder andere op de overweging dat het noodzakelijk is dat: " $(. .$.$) een woord hetwelk een geheel proces, een geheel leven, een geheel$ individu vertegenwoordigt, tot de ontologische opvatting van dat proces voert." (ibid., p. 132). De nadruk op de waarneming verleidde Ramaer echter ook tot een vorm van ontologie. Doordat hij een materieel criterium hanteerde voor het hebben van, of lijden aan, een bepaalde ziekte, was ziekte geen abstract begrip meer, maar iets in de werkelijkheid. Er vond ook bij Ramaer een reïficatie van het begrip "ziekte" plaats. De processen die ten grondslag liggen aan ziekten zijn weliswaar complex, maar tevens concreet, aldus Ramaer. Het zijn feitelijke processen, die door de wetenschap uiteindelijk te reconstrueren zijn. De ontologische trekjes van Ramaers visie treden bijvoorbeeld aan de dag in zijn opvatting van geestesziekte. Evenals Griesinger verbond Ramaer geestesziekte met stoornissen in de hersenfysiologie. Ook bij Ramaer blijkt dus dat het methodisch materialisme, dat zo nauwlettend metafysische standpunten als spiritualisme en materialisme trachtte te weren uit de wetenschap, in de negentiende eeuw vaak heeft geleid tot een concept van geneeskunde dat zich toch niet geheel wist te ontdoen van ontologische trekjes. 
In de bovengenoemde vierde wet besprak Ramaer zijn visie op de therapie. De fysiologische, natuurwetenschappelijke geneeskunde verschaft zijns inziens de wetten op basis waarvan prognose en diagnose mogelijk zijn, zoals uit de tweede en derde wet duidelijk bleek. Doordat de geneeskunde zich baseert op de kennis van de wetten des levens, is vervolgens de stap naar de therapie gering: "Heeft men daarentegen door de kennis der ziekteprocessen eenen vasten grondslag voor de prognosis verworven, - dan weet men ook wanneer men mag, wanneer men moet nalaten om in te grijpen. (...) Tot therapeutisch gebruik komt het enkel aan op de kennis der wetten die elk middel bij de werking op het organisme volgt, en om die kennis te verkrijgen kan in de eerste plaats het onderzoek hunner werking in den physiologischen dienen, (...)" (Ramaer, $1851 \mathrm{a}$, p. 19 en p. 22). Het is niet verwonderlijk dat Ramaer zich op basis van zijn anti-ontologische fysiologische opvatting van geneeskunde keerde tegen het idee van specifieke geneesmiddelen (vgl. Ramaer, 1844b). Hij blijkt dus wel belang te hechten aan therapie, maar dan niet zozeer aan een therapie die gebaseerd is op empirische gegevens omtrent de werking van een bepaald middel. Zijn idee van therapie behelsde veeleer de beïnvloeding van een levensproces, waarvan de wetmatigheden bekend zijn. Therapie betekende voor Ramaer, evenals voor Virchow, het reguleren van uitwendige materiêle levensomstandigheden.

In Ramaers beschouwing van de geneeskunde als stellige wetenschap vertoont het ziektebegrip grote overeenkomsten met dat van Virchow. Ziekte was een vorm van leven, ontstaan door de inwerking van ongewone omstandigheden. Ramaer huldigde ook een opvatting van het klinisch oordeel, die eerder naar voren is gekomen. Ramaer kon het klinisch oordeel wetenschappelijk funderen, aangezien de geneeskunde een stellige wetenschap is die de wetten kan aandragen omtrent het lichamelijk functioneren. Op basis van de wetmatige kennis van de geneeskunde konden diagnose, prognose en therapie op vrijwel gelijke wijze, als een wetenschappelijke verklaring en voorspelling, worden voltrokken.

Ten aanzien van de psychiatrie geldt eveneens dat Ramaer zich sterk heeft beijverd voor een gezichtsverbetering. Hij pleitte ervoor dat krankzinnigengestichten niet slechts als laatste oplossing moeten worden gezien in de zorg voor krankzinnigen. Voor de zieke zelf is een krankzinnigenhuis, dat aan de eisen der moderne tijd voldoet, een hele verbetering, aldus Ramaer. Men wordt niet gebonden of gekneveld en niet zo ruw en onbehoorlijk bejegend als thuis (vgl. Ramaer, 1846a, p. 72). Bovendien hield de krankzinnigenbehandeling meer in dan bewaring, men hoopte de krankzinnigen te genezen. Rond 1850 groeide in Nederland het aantal krankzinnigengestichten en het aantal opgenomen lijders aanzienlijk (vgl. Schneevoogt, 1868, p. 162). Ramaer baseerde zijn vertrouwen in de psychiatrie op het wetenschappelijk karakter van de krankzinnigenbehandeling. 
Ramaers ideeën over psychiatrie sloten nauw aan bij die van Griesinger, die als de grondlegger van de neuropsychiatrie wordt beschouwd (vgl. Verwey, 1980). In Duitsland twistten tussen 1820 en 1840 twee sterk wijsgerig bepaalde psychiatrische stromingen met elkaar over de oorzaken van krankzinnigheid. Deze veelal religieus gekleurde debatten waren volgens Griesinger nutteloos. Hij wilde ze de rug toe keren, door geen metafysische uitspraken te doen en door zich louter op een wetenschappelijk standpunt stellen. Ramaer viel hem hierin bij. De psychiatrie was al zo vaak ten prooi gevallen aan de strijd tussen concurrerende filosofische en theologische stelsels, dat ze nu de minst zekere tak van de geneeskunde leek. Dergelijke stromingen trachtten telkens behandelingsplannen door te drijven op grond van hun wijsgerige mensvisie, zonder oog voor de praktijk. Dat was Ramaer een doorn in het oog, juist omdat de ontwikkeling in de wetenschap zover gevorderd was dat de wetenschap een gefundeerde praktijk, een rationele behandelwijze mogelijk maakte (vgl. Ramaer, 1846a, pp. 50 e.v.). Door zich te onthouden van metafysische uitspraken en door de psychiatrie haar terechte plaats als onderdeel van de geneeskunde te gunnen zou deze onverkwikkelijke stand van zaken uit de wereld geholpen kunnen worden, zo meende Ramaer.

Volgens Ramaer behoorde de psychiatrie zich bezig te houden met zielsziekten vanuit een natuurwetenschappelijk, oftewel vanuit een methodisch materialistisch, perspectief. De bestudering van de hersenprocessen en het zenuwstelsel en de relatie daarvan met overige lichaamsprocessen vormde zijns inziens de grondslag voor het wetenschappelijk begrip van de geestesziekte. Krankzinnigheid werd door Ramaer, zoals hij zelf zei, "geheel ligchamelijk" opgevat. De wetenschap heeft geen recht om uitspraken te doen over de kwestie of de rede of het verstand van een hoger beginsel afhangen, aldus Ramaer (vgl. Ramaer, 1852, pp. 2122). Hij kon er evenwel niet omheen om enkele uitspraken te doen over de mens als samenstel van lichaam en ziel. Beide zijn nauw verbonden maar toch te onderscheiden, aldus Ramaer. De ziel houdt Ramaer voor enkelvoudig en onveranderlijk, de ziel kan niet ziek zijn. "Er bestaan derhalve geene ziekten der rede, geene ziekten der ziel, en de krankzinnigheid is eene ziekelijke uiting der geestvermogens, welke van het ligchaam afhangen: die vermogens zijn het bewustzijn, de voorstelling en de idecènassociatie" (Ramaer, 1846a, p. 7). Ramaer had dus wel een bepaalde wijsgerige mensopvatting, die doorklonk in zijn opvatting van psychiatrie. Maar doordat hij zich in eerste instantie oriënteerde op de methodologische uitgangspunten van de (natuur)wetenschap, leek zijn mensbeeld als filosofisch uitgangspunt niet door te dringen in de wetenschap.

Ramaers psychiatrisch onderzoek richtte zich op het afwijkend functioneren van de geestvermogens die van het lichaam afhangen. Geestesziekten waren zijns inziens bepaalde abnormale processen en geen statische lichaamsveranderingen, geen anatomisch aanwijsbare laesies. Ze konden echter wel resulteren in vormveranderingen, aangezien samenstelling en verrichting samenhangen. Geestesziekten werden volgens Ramaer veroorzaakt door prikkels van materiële aard. 
Bij de verklaring van afwijkend functioneren, in het diagnostisch proces, diende de arts zich dan ook te richten op veranderingen in het gehele lichamelijke functioneren van de patiểnt. In de psychiatrie bezitten weliswaar zedelijke oorzaken verreweg het overwicht boven lichamelijke, aldus Ramaer, maar deze worden door hem toch ook materieel geduid. Hij ging ervan uit: " $(. .$.$) dat, even als$ andere inwerkingen, elke zedelijke invloed ook door tusschenkomst der uitwendige zintuigen in het inwendig werktuig wordt opgenomen, om er tot voorstelling te worden, en dat, wanneer die invloed dikwerf terugkeert, het orgaan der voorstelling eene zekere voorbeschiktheid verkrijgt om in denzelfden toestand te geraken, zoo zeer zelfs, dat iedere uitwendige aanleiding door tusschenkomst der ideënassociatie de genoemde verandering en dus dezelfde voorstelling zal in het wezen roepen. Het gevolg hiervan zal hetzelfde zijn, wat wij in ieder ander ligchaamsdeel waarnemen, wanneer het langer dan gewoonlijk aan eenen en dezelfden invloed blootgesteld is, dat wil zeggen, er ontstaat eerst ongewone werkdadigheid van deszelfs zenuwen, daarna verlamming van deszelfs bloedvaten, bloedophooping, vertraging van den bloedsomloop en zelfs ontsteking met derzelver gevolgen (...)" (Ramaer, 1846a, pp. 61-62). In latere jaren werkte Ramaer deze opvatting verder uit.

Ramaer relateerde de verschijnselen van krankzinnigheid aan fysiologische stoornissen. Daarbij maakte hij gebruik van resultaten van Donders, die de bewegingen der hersenen had onderzocht. Uit zijn studie van de relatie tussen drukverschillen in de bloedbaan en de stofwisseling in de hersenen concludeerde Donders dat het rationeel was om functionele stoornissen te verklaren op grond van wijzigingen in de stofwisseling (Donders, 1849-1850). Ramaer veronderstelde vervolgens dat veranderingen in de bloeddruk en in de stofwisseling. veroorzaakt door externe invloeden, zoals drankgebruik, of door afwijkend functioneren van andere organen, resulteren in onderscheiden ziektebeelden, in verschillende vormen van krankzinnigheid. Op basis van zijn driedeling in geestvermogens die ten prooi kunnen vallen aan ziekte, de eerdergenoemde driedeling bewustzijn, voorstelling en ideeënassociatie, en de factor hersenwerking. die verhoogd of verlaagd kan zijn, kwam Ramaer tot een schematische voorstelling van de verschillende vormen van krankzinnigheid (vgl. Ramaer, 1852, p. 25; Ramaer, 1855, p. 83). Aldus werd door Ramaer de psychopathologie gefundeerd op de hersenfysiologie.

Ramaer ging er ook bij zijn psychiatrische beschouwingen van uit dat ziek en gezond geen wezenlijk onderscheiden toestanden zijn. Ziek en gezond verschillen gradueel, bij krankzinnigheid net zo goed als bij andere ziekten. De onderscheiden vormen van krankzinnigheid verschillen van het gewone leven doordat ze voortkomen uit vermeerderde dan wel verminderde hersenwerking, Maar de overgang van gezond naar ziek zielenleven geschiedt langs zo vele wegen en zo onmerkbaar, zegt Ramaer, dat men bijna nooit in staat is om te bepalen waar de gezonde hersenwerking ophoudt en de krankzinnigheid begint (vgl. Ramaer, 1852, p. 24). 
In Ramaers ideeên over behandeling wordt dezelfde voorkeur voor een materiêle duiding aangetroffen. Dat betekent niet dat hij meende dat alleen directe materiële beinvloeding van het functioneren van de patiënt is geboden. Hij waardeerde zeker opvoeding, godsdienstige vorming arbeid, goedheid en liefde in het behandelingsproces. In Engeland vierde halverwege de negentiende eeuw de "moral treatment" oftewel de "zedekundige behandeling" hoogtij. Deze baseerde zich op een niet-dualistische mensvisie (vgl. Everts \& Van Leeuwen, 1852 53, pp. 120 e.v.). De krankzinnige werd gezien als een individu, één organisch geheel, waarin alle fysieke, intellectuele en morele vermogens zijn verenigd. In het behandelingsplan werd op al deze vermogens ingewerkt om genezing te bewerken. In dit systeem behoorde niet alleen somatisch gericht, medisch handelen tot de therapie maar deed men in therapeutisch kader ook aan lichaamsbeweging, godsdienstoefening en onderwijs. Deze behandelwijze vond ook onder de Nederlandse psychiaters aanhang, Ook Ramaer nam in zijn ideeën over behandeling elementen op uit de behandelingswijze van de "moral treatment"beweging. Hij leverde daarbij wel een eigen natuurwetenschappelijke interpretatie van het nut van dergelijke behandelwijzen en hij abstraheerde van het mensbeeld dat door de Engelse artsen met deze behandelwijze wordt verbonden. Zijn toepassing van deze vormen van therapie beargumenteerde hij op een voor de natuurwetenschappelijke oriêntatie in de geneeskunde specifieke manier. Wanneer Ramaer godsdienst, opvoeding, arbeid, enzovoorts aanprijst als behandeling, baseert hij zich hierbij op het materiële effect van dergelijke ingrepen. De inwerking van deze vormen van therapie werd, getrouw aan de uitgangspunten van de natuurwetenschappelijke definitie van de geneeskunde, als een fysischchemisch proces gewaardeerd.

In de volgende paragraaf zal worden ingegaan op de opvattingen van Ramaers tijdgenoot Donders. Ook diens positie zal worden gerelateerd aan de in de tweede helft van de vorige eeuw op de voorgrond tredende natuurwetenschappelijke visie op de geneeskunde.

\subsection{Franciscus Cornelis Donders (1818-1889)}

Franciscus Cornelis Donders werd geboren op 27 mei 1818. Hij studeerde geneeskunde te Utrecht aan de Rijkskweekschool voor militair-geneeskundigen en aan de universiteit. Hij begon zijn loopbaan als officier van gezondheid, eerst te Vlissingen, later te 's-Gravenhage. Hij promoveerde op 13 oktober 1840 in Leiden tot "doctor medicinae" op een dissertatie over ontleedkundige, ziektekundige waarnemingen aan het centraal zenuwstelsel (Donders, 1840). In 1842 werd hij docent in de "ontleedkunde en natuurkunde van den mensch" aan de Rijkskweekschool voor militair-geneeskundigen, waar hij zelf had gestudeerd. 
In Utrecht verrichtte hij onderzoek op het gebied van de histologie. Samen met de fysiologisch chemicus G. J. Mulder (1802-1880) heeft hij een belangrijke bijdrage aan de ontwikkeling van de histochemie geleverd. In dezelfde periode maakte hij ook een begin met zijn bekende onderzoekingen van het oog. In 1847 is Donders benoemd tot extra-ordinarius aan de Utrechtse hogeschool. In verband hiermee werd hij eervol ontslagen uit de militaire dienst. Ondanks aanbiedingen van andere universiteiten - er was zelfs sprake van dat Donders in 1849 de beroemde Duitse fysioloog Ludwig te Marburg zou opvolgen - bleef Donders in Utrecht (Fischer \& Ten Doesschate, 1958, p. 105; vgl. ook: Cranefield (ed.), 1982, p. 48). In 1863 volgde hij daar zijn leermeester J.L.C. Schroeder van der Kolk (1797-1862) op als gewoon hoogleraar in de fysiologie.

Donders heeft zich met verscheidene takken van geneeskunde beziggehouden en daarin ook internationaal roem verworven. Terwijl zijn eerste onderzoekingen pathologisch-anatomisch van aard waren, kwam hij al snel via de histopathologie uit bij de fysiologie en de oogheelkunde. Zoals blijkt uit zijn eigen onderzoek was Donders een groot voorstander van de fysiologische benadering binnen de geneeskunde. Voor zijn benoeming tot gewoon hoogleraar in de fysiologie vermeed hij echter de term "fysiologie", ondanks zijn fysiologische aanpak, om niet de schijn van concurrentie te wekken.

Donders gaf in Utrecht over talrijke onderwerpen onderwijs. Hij werd tot hoogleraar benoemd terwijl er geen vacature was, hij was professor "à la suite". Zijn leeropdracht was niet vast omschreven en daarom was hij tamelijk vrij in de keuze van de vakken die hij wilde doceren. Donders kende de Utrechtse situatie van nabij en hij wist van de bestaande leemten. Deze trachtte hij zoveel mogelijk op te vullen. Hij doceerde er gerechtelijke geneeskunde, medische politie in verband met gezondheidsleer, antropologie, weefselleer, algemene stofwisselingsleer en oogheelkunde. Mede door dit brede scala van vakken zette Donders zijn stempel op de medische opleiding in Utrecht en, via zijn leerlingen, ook op de opleidingen in de rest van Nederland. In de opsomming van de werkzaamheden van de auteurs van de feestbundel, die Donders ter gelegenheid van zijn zeventigste verjaardag door zijn dankbare leerlingen werd aangeboden, treedt de invloed van Donders op de Nederlandse geneeskunde in het algemeen duidelijk aan de dag (Snellen et al., 1888)

Donders' belang voor de ontwikkelingen in de Nederlandse geneeskunde blijkt mede uit de invloed die hij heeft gehad bij de totstandkoming van twee belangrijke instituten. In 1859 werd het Nederlands Gasthuis voor behoeftige en minvermogende ooglijders geopend. Donders was de stichter en gedurende 25 jaar tevens de directeur van dit gasthuis, dat tegelijk fungeerde als oefenschool voor aanstaande oogartsen. In 1866, dat wil zeggen in de periode dat Donders hoogleraar was in de fysiologie, werd tevens het nieuwe "physiologisch laboratorium 
der Utrechtsche Hoogeschool" geopend. In dit laboratorium, dat was ingericht volgens zijn aanwijzingen, zouden generaties Utrechtse studenten in de geneeskunde de colleges en het praktisch onderricht volgen.

Donders genoot niet alleen in Nederland, maar ook internationaal aanzien. Het meest bekend was hij door zijn in 1864 in Londen gepubliceerde werk Anomalie of accomodation and refraction of the eye (Donders, 1864). Met zijn overig onderzoek trok hij eveneens de aandacht van buitenlandse voorvechters van de natuurwetenschappelijke geneeskunde. Hij reisde regelmatig en hij onderhield veel schriftelijke contacten met fysiologen en artsen, zoals Helmholtz en de oogarts A. von Graefe (1828-1870), en ook met andere wetenschapsbeoefenaars waaronder Ch. Darwin (1809-1882). Von Graefe's brieven aan Donders zijn bewaard gebleven en in 1935 uitgegeven. Uit deze correspondentie blijkt naast de vriendschap ook het collegiaal overleg over nieuwe ideeēn en methoden in de oogheelkunde (vgl. Weve \& Ten Doesschate, 1935). Dankzij zijn relaties met wetenschapsbeoefenaren in de rest van Europa raakte Donders onmiddellijk op de hoogte van de discussies en van de recente onderzoeksresultaten binnen de geneeskunde. Ditzelfde netwerk stelde hem ook in staat om zijn eigen onderzoekingen onder de aandacht te brengen. Zijn werk werd door vooraanstaande buitenlandse wetenschapsbeoefenaars geciteerd.

Donders was tevens als redacteur van medisch wetenschappelijke tijdschriften actief. Van 1845 tot $1856 \mathrm{gaf}$ hij in samenwerking met enkele anderen het Nederlandsch Lancet uit. Tevens maakte hij deel uit van de redactie van het Nederlandsch Archief voor Genees- an Natuurkunde. In 1846-1848 publiceerde Donders, zoals gezegd, tezamen met Van Deen en Moleschott, een tijdschrift dat beoogde om de Nederlandse onderzoeksresultaten op het gebied van de anatomie en fysiologie aan een buitenlands publiek te presenteren: de Holländische Beiträge zu den anatomischen und physiologischen Wissenschaften, dat later werd opgevolgd door het Archiv für die holländische Beiträge zur Natur- und Heilkunde. Daarnaast heeft hij enkele oogheelkundige periodieken uitgegeven.

Donders is opgeleid in de periode dat de natuurfilosofie en andere wijsgerige systemen opgeld deden in de Nederlandse geneeskunde. De onderzoeksmethoden en de behandelingsmethoden van de diverse hoogleraren liepen in deze tijd sterk uiteen. In een lezing in 1879 beschreef Donders de situatie rond 1840 . Men huldigt vrij algemeen een vorm van therapeutisch scepticisme, zo stelde hij, en laat de natuur de vrije loop in de hoop op de levenskracht en de genezende werking van de natuur. Daarenboven werd de geneeskunde beheerst door de teleologie (vgl. Donders, 1879, geciteerd in Fischer \& Ten Doesschate, 1958, p. 185). Donders' werk heeft er voor een belangrijk deel uit bestaan om deze principes te bestrijden. Het was mede door hem dat rond 1880 de beoefenaars van de medische wetenschap de onhoudbaarheid van deze uitgangspunten als vanzelfsprekend beschouwden. 
Toen Donders in 1842 aan de Rijkskweekschool voor militair-geneeskundigen ging werken, drongen in Nederland de vernieuwingen door die in Duitsland op gang waren gekomen. De jonge generatie binnen de Nederlandse geneeskunde begon onderzoek en waarneming als essentieel voor het vak te beschouwen; men ging experimenteren, percuteren, ausculteren en microscopisch onderzoek verrichten. Zij lieten zich hierbij inspireren door het werk van Henle, Müller, Ludwig, Helmholtz, Du Bois-Reymond en andere bekende natuurwetenschappelijke geneeskundigen. In Utrecht werkten Donders en zijn vriend en collega Mulder - geheel in lijn met deze nieuwe benaderingswijze - samen aan microchemisch onderzoek van dierlijke weefsels.

Mulder hield in dat jaar een pleidooi voor de erkenning van de waarde der natuurkundige wetenschappen voor de geneeskunde. Daarbij rangschikte hij expliciet de geneeskunde onder deze wetenschappen. Enerzijds verklaarde hij: "(...) de physica zal $\mathrm{u}$ alles toelichten, wat in het menselijk ligchaam merkwaardigs valt op te merken, en hetwelk dit ligchaam gemeen heeft met al wat stoffelijk tot de aardoppervlakte behoort" (Mulder, 1842, p. 10). Eerder bracht hij naar voren: "Dat de Geneeskunde eene Natuurkundige wetenschap is, behoeft niet herinnerd te worden. Wat zou zulk eene wetenschap anders zijn, waarvan het object een stoffelijke klomp is, beheerscht door duizende natuurkrachten, geplaatst op eene der kleinere planeten en blootgesteld aan vele invloeden der Natuurkundige werkende oorzaken" (ibid., p. 6). Daarnaast stelde hij dat in het menselijk lichaam een onstoffelijk wezen woont, de geest, maar daar houdt de geneeskunde zich niet mee bezig. De geneeskundige beperkt zich immers, in zijn visie, tot de zorg voor het stoffelijk omhulsel en voor de gestoorde werkingen ervan (vgl. ibid., p. 30). De mens kon derhalve in de medische wetenschap zonder bezwaar gezien worden als een natuurobject als elk ander, aldus Mulder: "Wij verkeeren in eene dwaling, indien wij meenen, dat het menschelijk ligchaam een op geheel eigene wijze gebouwd en georganiseerd voorwerp is" (ibid., p. 14). In zijn oratie - die hij in het Nederlands hield - getiteld De harmonie van het dierlijke leven. De openbaring van wetten, schetste Donders de uitgangspunten en grondgedachten van zijn onderzoek (Donders, 1971 (1848)). Hij kondigde aan dat hij de natuur op empirische wijze wilde bestuderen en dat hij de oorzaken van wat wordt waargenomen zou trachten te achterhalen. De geneeskunde beschouwde hij als natuurwetenschap, zoals blijkt in het slot van zijn oratie. Hij houdt daar de studenten voor dat de kennis die zij willen verwerven, door hen zelf verzameld moet worden: "De kennis, die gij verlangt, ligt in de voorwerpen en verschijnselen der natuur opgesloten: zintuigelijke waarneming van deze is de éénige wijze, waarop zij te verkrijgen is. (...) Gij moet leeren zien, hooren, ruiken, proeven en tasten; en gij moet het bewustzijn hebben, dat gij met deze vermogens tot ware kennis kunt geraken" (Donders, 1971 (1848), pp. 65-66). 
Donders was van mening dat de werkwijze van de wetenschappen die zich met de dode natuur bezighouden tevens de geëigende weg vormt voor de bestudering van de natuur als geheel. Beide vormen van natuur moesten met behulp van overeenkomstige, dat wil zeggen natuurwetenschappelijke, methoden worden onderzocht (vgl. ibid., p. 9). Donders constateerde dat men in het algemeen erkent dat buiten de levende natuur niets dan wetten, niets dan noodzakelijkheid heerst. Planten en dieren wil men daarentegen, getroffen door de harmonie in de natuur, vanuit een teleologisch standpunt beschouwen. Donders stelde daar tegenover dat men in de wetenschap niet behoort te vragen naar een nooit bewijsbaar doel, maar naar oorzaken. Hij schetste hoe in de levende natuur overal wetten en oorzaken werkzaam zijn, die de basis vormen van de harmonie. Speculatie over het doel van deze harmonie was zijns inziens niet zinvol. Het formuleren van dergelijke doelen was voor de wetenschapsbeoefenaar ontoereikend omdat het geen bevredigende antwoorden opleverde. Bovendien was het aanmatigend. Volgens Donders was het niet geoorloofd om in de bestudering van de levende natuur een andere vraagstelling te hanteren dan ten aanzien van de dode natuur. In beide gevallen moest de wetenschapsbeoefenaar vragen "Waardoor?", niet "Waartoe?" Het is de taak van de natuuronderzoeker, en daartoe rekent Donders ook de arts, om de oorzaken te doorgronden die de basis vormen van de harmonie. Niet de kennis van de harmonie in de natuur vormt het eindpunt van diens streven, maar die van de natuurwetten. In het onderzoek van de levende natuur moeten en kunnen, zo stelde Donders met nadruk, net als bij de bestudering van de dode natuur, de natuurwetten op een natuurwetenschappelijke wijze worden opgespoord, al is dit niet altijd even eenvoudig. Donders stelde daarenboven dat hetzelfde geldt voor de studie van de mens. Zijns inziens onderscheidt de mens zich voor de natuuronderzoeker niet van de rest van de natuur. Donders rangschikte de mens in dit verband zonder meer onder de diersoorten (vgl. ibid., p. 49).

Dit standpunt komt ook duidelijk naar voren in de Handleidingen tot de natuurkunde van den gezonden mensch die Donders tezamen met A. F. Bauduin (1822-1885) publiceerde in 1851 en 1853 . "De natuurkunde van de mensch leert ons de verschijnselen kennen, die de levende mensch aanbiedt. Die levensverschijnselen staan in een innig verband met den vorm, de natuurkundige eigenschappen en de scheikundige zamenstelling der onderscheidene ligchaamsdeelen: het is de taak der physiologie, dit verband op te sporen en aan te wijzen" (Donders \& Bauduin, 1851, p. 2). In hun bespreking van de relatie van de fysiologie tot de andere wetenschappen geven Donders en Bauduin aan dat er nauwe betrekkingen bestaan tussen de fysiologie der planten, die der dieren en die der mensen en dat door vergelijking verschijnselen uit deze vakgebieden onderling verhelderd kunnen worden: "De proefondervindelijke physiologie kan meestal alleen de verschijnselen der dieren raadplegen, en de kennis, hierbij opgedaan, 
bepaaldelijk bij de hoogere dieren kan, met eenige omzigtigheid, op den mensch worden overgedragen. De physiologie der dieren is dus onafscheidelijk van die van de mensch" (ibid., pp. 6-7).

De toepassing van kennis uit de dierfysiologie werd niet alleen met praktische overwegingen gelegitimeerd. Donders en Bauduin benadrukken ook dat er geen principiēle gronden zijn om dit af te wijzen. De natuur is immers een samenhangend geheel en er bestaan geen natuurlijke grenzen tussen bepaalde natuurobjecten, alleen willekeurige (vgl. ibid., p. 8 en p. 12). Classificaties en vergelijkingen op grond van allerlei kenmerken zijn, naar hun mening, wel mogelijk. De mens wordt door Donders en Bauduin opgenomen in de rij natuurobjecten en, na vergelijking met andere dieren, als het meest ontwikkelde zoogdier aangeduid. Dit moge blijken uit het volgende uitvoerige citaat: "Hoezeer de mensch aan het hoofd van den dierenschakel geplaatst is, munt niet in alle opzigten zijn ligchaam boven dat der hoogere dieren uit. (...) Het voornaamste kenmerk, waardoor de mensch zich van alle dieren onderscheidt, bestaat in de hoogere ontwikkeling zijner geestvermogens en zijne zedelijke natuur. Deze staat in naauw verband met de meerdere ontwikkeling zijner hersenen, met den zamengestelden spiertoestel van zijn aangezigt en met zijn spraakvermogen, waardoor hij in staat gesteld wordt, zijne gedachten aan anderen mede te deelen. (...) De hersenen zijn de organen, waaraan de hoogere vermogens, het gevoel, het verstand en de wil, zijn verbonden. Bij den mensch zijn deze in verhouding tot de uittredende zenuwen grooter van omvang en gewigt dan bij eenig ander dier. (...) Bij de gewervelde dieren waar hersenen en ruggemerg aanwezig en in een been- of kraakbeenachtig kanaal besloten zijn, wordt eene langzaam voortgaande ontwikkeling van het zenuwstelsel waargenomen. (...) en bij den mensch zien wij. vooral wat de hersenen aangaat, den hoogsten trap van volkomenheid bereikt" (ibid., pp. 23-26).

Ook met betrekking tot de voedingsleer heeft Donders zijn methodologische uitgangspunten duidelijk naar voren gebracht. Als de mens vanuit het perspectief van een rationele voedingsleer wordt onderzocht, wordt hem een plaats toegewezen in het dierenrijk. "Wat goldt in dit opzigt van den mensch?", zo brengt hij naar voren, "De bouw van zijn ligchaam en niet minder zijne neigingen, - waarin de voorwaarden zich openbaren, onder welke ons geslacht geworden is, - wezen hem eene plaats aan tusschen plantetende en vleeschetende dieren" (Donders, 1865, p. 2). Wil men vervolgens in de fysiologie wetenschappelijk verklaren hoe voeding samenhangt met spierarbeid en warmteontwikkeling. dan was de wet van behoud van energie - Donders verwees naar de formulering hiervan uit 1842 door R. Mayer (1814-1878) - zijns inziens een vruchtbaar uitgangspunt. Dit voorbeeld illustreert nogmaals dat vanuit een wetenschappelijk standpunt de levende natuur, de dode natuur en de mens door Donders gelijk werden gesteld. 
Donders' visie op de verhouding tussen filosofie en wetenschap correspondeert met de eerder geschetste opvattingen van de natuurwetenschappelijk georiênteerde geneeskundigen. Hij wilde alle filosofische ideeên weren uit de wetenschap en tevens levensbeschouwing en wetenschap duidelijk van elkaar afgrenzen. Donders' materialisme behoort evenals bij de eerdergenoemde voorvechters van de natuurwetenschappelijke geneeskunde als een vorm van methodisch materialisme te worden beschouwd. Hij wees een principieel ontologisch materialisme af en hij achtte het materialisme van zijn vriend Moleschott onaanvaardbaar (vgl. Fischer \& Ten Doesschate, 1958, pp. 151-152; Romein, 1956 (1938-1940), p. 699; Ter Laage, 1980, pp. 196-197). Op wijsgerige vlak huldigde Donders veeleer een metafysisch agnosticisme. Het materialisme zag hij uitdrukkelijk als een werkhypothese, noodzakelijk bij de beoefening van wetenschap. Moleschotts materialisme was daarentegen veel radicaler en het steunde op een vervlechting van filosofie en fysiologie (vgl. o.a. Ter Laage, 1980, pp. 228 e.v.). Overigens wordt ook wel verdedigd dat Moleschotts materialisme niet zozeer als een ontologisch, maar ook als een methodologisch materialisme moet worden beschouwd (vgl. Peeters in Moleschott, 1989, p. 42).

Donders was, zoals gezegd, net als de eerder besproken aanhangers van de natuurwetenschappelijke geneeskunde een fel tegenstander van de teleologie in de wetenschap. Zijn leermeester Schroeder van der Kolk wilde daarentegen wel natuurwetenschappelijk onderzoek combineren met een teleologische beschouwingswijze (Schroeder van der Kolk, 1835). Schroeder van der Kolk stond daarin overigens niet alleen. In de eerste decennia van de negentiende eeuw was, zoals hiervoor is uiteengezet, de combinatie van empirische natuurwetenschappelijke onderzoeksmethoden enerzijds en teleologische vitalistische opvattingen anderzijds wijd verspreid.

In het "Voorberigt" van zijn oratie zette Donders uiteen hoe hij ertoe was gekomen om de teleologische beschouwingswijze aan de orde te stellen. Hij constateerde met Henle dat deze benadering zich in de fysiologie en pathologie van het dierlijk leven nog bijna overal krachtig deed gelden. Daarom was het onderwerp volgens hem van voldoende gewicht om het in een openbare rede te bespreken. De stelling die Donders verdedigde, luidde dat de teleologische zienswijze geweerd moet worden van het natuurkundig terrein, aangezien het haar ontbreekt aan een vast fundament. De teleologische beschouwingswijze leidt daardoor tot dwalingen en willekeurige beschouwingen die geenszins stroken met het stellige karakter van wetenschap (vgl. Donders, 1971 (1848), pp. IIIIV). De filosofie mocht wat Donders betreft, beslissen of men in de natuur met recht van een doel mag spreken, maar dergelijke ideeēn horen niet tot het terrein van de natuuronderzoeker, die zoekt naar de natuurwetten die de grond vormen van de harmonie in de natuur (vgl. ibid., p. 9 en p. 21). 
Het is opmerkelijk dat in de "Handleidingen tot de natuurkunde van den gezonden mensch", die Donders zoals boven aangegeven tezamen met Bauduin heeft gepubliceerd, de teleologische benadering wel een functie kreeg. In de natuurkunde van de mens, de fysiologie, werd een tweedeling aangebracht: de bijzondere natuurkunde van de mens die zich bezighoudt met samengestelde verrichtingen en de algemene natuurkunde van de mens, die de grondverschijnselen onderzoekt. In het inleidende hoofdstuk stellen Donders en Bauduin dat binnen de eerstgenoemde het teleologisch standpunt een bepaald nut heeft: "De bijzondere natuurkunde van den mensch gaat daarentegen van de bijzondere werkingen uit, die zij tot bepaalde verrigtingen en hieraan beantwoordende toestellen vereenigt (ademhaling, spijsvertering, bloedsomloop). Deze vereeniging geschiedt van een teleologisch standpunt. Tot elke hoofdverrigting worden, namelijk, eene reeks meestal ongelijksoortige verschijnselen teruggebragt, die slechts in zoo verre met elkander in verband staan, als zij tot verwezenlijking van hetzelfde vooronderstelde doel bijdragen. (...) Om het onderling verband der physiologische verschijnselen meer aanschouwelijk te maken, worden zij vereenigd tot een zeker aantal verrigtingen, van een teleologisch standpunt ontworpen" (Donders \& Bauduin, 1853, pp. 1-2). De teleologische beschouwingswijze werd hier dus wel aanvaard en zelfs aanbevolen om bepaalde verbanden tussen verschillende typen verschijnselen te leggen. Bovendien, zo constateren de schrijvers, sluit deze benadering - die ook naar voren komt in termen als organisme, orgaan of functie - aan bij het alledaagse denken en spreken. Maar deze acceptatie is beperkt, de teleologie heeft uitsluitend een functie als heuristisch middel.

Donders en Bauduin attenderen er daarnaast ook op dat het van belang is dat er zorgvuldig wordt omgegaan met de term "teleologie". De fysiologie dient zich zorgvuldig te onthouden van het zoeken naar eindoorzaken. Het doel waartoe de verschillende verschijnselen in de natuur geordend zijn, moet niet gezien worden als een door het menselijk verstand ontworpen plan, zoals bij kunstmatige, dat wil zeggen door de mens vervaardigde, werktuigen: "Bij deze laatsten alléén kunnen wij verder vragen, met welk doel en hoe de verschillende zamenstellende deelen vervaardigd zijn; ten opzigte der bewerktuigde voorwerpen moet als ideaal ons voor den geest zweven de kennis van de wijze hunner ontwikkeling en van den grond van hun ontstaan" (ibid., pp. 2-3).

Zoals Virchow de eenheid van de levende natuur aangaf met de term "leven", zo beschreef Donders deze met de term "harmonie". Hij legde er de nadruk op dat in de natuur de harmonie zich steeds ontwikkelt. Er zijn geen eindtoestanden, maar prikkels die inwerken op bestaande organisaties. Deze invloeden kunnen door de organisatie, dat wil zeggen het organisme, met meer of minder succes worden verwerkt. Bij te zeer afwijkende prikkels ontstaan er stoornissen en zijn wij van mening dat de harmonie is verstoord. 
Donders heeft zich al vroeg in zijn loopbaan ontwikkeld van patholoog-anatoom en histoloog tot fysioloog. Vanuit zijn fysiologische aanpak verklaarde hij, evenals de hierboven besproken natuurwetenschappelijk georiênteerde geneeskundigen, ziekten in termen van een proces. Het ging om stoornissen met een bepaald verloop. Deze stoornissen, Donders rekende daar onder andere ontstekingen toe, bestaan tijdens het leven en niet na de dood. Het was zijns inziens dan ook onjuist om het gebruik van dergelijke begrippen te baseren op bepaalde anatomische afwijkingen (vgl. De Josselin de Jong, 1930, pp. 55-56).

Zijn de stoornissen zodanig dat de fysische voorwaarden van het harmonisch verband tussen de verschillende lichaamsdelen worden opgeheven, dan is het leven niet langer bestaanbaar en treedt er een andere toestand in, die van ontbinding, Donders formuleerde dit als volgt: "Grenzen dan ook tusschen leven en dood bestaan slechts voor den oppervlakkigen beschouwer. Het eindigen van het leven aan den laatsten ademtogt te verbinden, verraadt gebrek aan inzigt in hetgeen aan het leven ten gronde ligt. (...) Door duizenden van overgangen maakt de stofwisseling in de weefsels, die aan 't gezonde leven ten gronde ligt, plaats voor die wisseling, welke wij ontbinding noemen; en al deze verschijnselen, leven, stoornis, ontbinding, zijn evenzo noodwendig en volgen elkander wettig op" (Donders, 1971 (1848), p. 33).

In deze schets van de theoretische uitgangspunten van Donders treedt zijn verwantschap met de natuurwetenschappelijke oriëntatie in de geneeskunde duidelijk aan het licht. Empirisch onderzoek naar de oorzaken van het verloop van de gebeurtenissen in de natuur vormt de centrale lijn in Donders' werk. Hij huldigde de mening dat voor de wetenschap de dode natuur, de levende natuur en de mens gelijk zijn. Bovendien was zijns inziens de enige wetenschappelijke benadering van de natuur die van de natuurwetenschap, die speurt naar grondstoffen en grondkrachten (vgl. ibid., p. 56). Uitdrukkelijk stelde hij dat hij door deze opvatting geenszins tot het kamp van de wijsgerige materialisten gerekend diende te worden. Wetenschap en levensbeschouwing wilde hij juist streng gescheiden houden. Donders profileerde zich als een methodologisch materialist, zoals velen van de natuurwetenschappelijk georiënteerde geneeskundigen. De natuurfilosofie en zeer nadrukkelijk ook de teleologische beschouwingswijze in de wetenschap, werden door hem verworpen. Ziekte was volgens hem niet een wezenlijk verschillende toestand van gezondheid. Zelfs leven en dood waren, aldus Donders, vanuit de wetenschap bezien, geen streng gescheiden fenomenen. 
Met de bovenstaande beschrijvingen van de opvattingen van Ramaer en Donders is een indruk gegeven van de receptie van de natuurwetenschappelijke geneeskunde in Nederland in de tweede helft van de negentiende eeuw. In Donders opvattingen kwamen vooral het verzet tegen het vitalisme en het methodisch materialisme naar voren. Ramaer benadrukte met name het grote belang van de fysiologie en verwierp met kracht de ontologische opvattingen. Beiden beklemtoonden het wetmatige karakter van de geneeskunde. Sinds de tijd van Ramaer en Donders is het aanzien van de geneeskunde, waar beiden zich voor inzetten, belangrijk verhoogd. De karakteristiek van het natuurwetenschappelijke wetenschapsideaal in de geneeskunde, die in de drie eerste paragrafen van dit hoofdstuk is gepresenteerd, vormde het kader waarbinnen de denkbeelden van deze medici in de negentiende eeuw werden geïnterpreteerd. De beschrijvingen van de opvattingen van Ramaer en Donders boden een concretisering van dit ideaal. 



\section{Geneeskunde als levenswetenschap}

\subsection{Van mechanisme naar organisme}

Aan het eind van de negentiende eeuw raakte de gezaghebbende positie van de natuurwetenschappelijk georiënteerde geneeskunde over zijn hoogtepunt heen. In Duitsland en in Nederland, waar men zich ook in deze periode nauw bij de Duitse opvattingen aansloot, maar eveneens in de Angelsaksische landen, waren na het aanvankelijke enthousiasme over deze opvatting van geneeskunde kritische geluiden te vernemen.

De kritiek richtte zich op uiteenlopende aspecten van de natuurwetenschappelijke geneeskunde. Er werd in eerste instantie geen concurrerend alternatief geformuleerd. Er was eerder sprake van een relativering van de positie van de natuurwetenschappelijke geneeskunde op verschillende fronten. Na verloop van tijd ontstond echter een meer samenhangende nieuwe visie. De geneeskunde werd daarbij niet langer op één lijn gesteld met de natuurkunde en de scheikunde. Geneeskunde werd met nadruk omschreven als levenswetenschap.

In de onderstaande schets van (de genese van) de levenswetenschappelijke gedefinieerde geneeskunde blijkt duidelijk dat men in de analyse van een wetenschappelijk debat niet alleen wordt geconfronteerd met wijsgerige kritiek op de fundamentele uitgangspunten van deze geneeskunde maar ook met praktische overwegingen. Opvallend zijn bijvoorbeeld de klachten dat de natuurwetenschappelijke geneeskunde ondanks haar pretenties nog niet zo ver is gevorderd in de realisering van haar praktisch vermogen. In dit kader worden bepaalde kwesties, die vanuit het natuurwetenschappelijk perspectief niet of niet volledig konden worden verklaard, voor het voetlicht gehaald.

Eén van de kwesties die aan het eind van de vorige eeuw de gemoederen bezighielden, was die van de verklaring van het ontstaan van ziekten en van de overgang van gezond naar ziek. Het bleek moeilijk te zijn om louter op grond van in de natuurwetenschappen geldige factoren te verklaren waarom het ene individu wel door een ziekte wordt getroffen en het andere niet. Zelfs de bacteriologie, die aan het eind van de vorige eeuw opkwam en in dit verband juist de meest veelbelovende benadering leek, kon niet eenduidig vaststellen welke voorwaarden bepalend zijn voor het optreden van ziekte. De overgang van gezond naar ziek en omgekeerd was geenszins zo gemakkelijk verklaarbaar en voorspelbaar als de natuurwetenschappelijk georiënteerde geneeskunde in het derde kwart van de negentiende eeuw had verondersteld. Om het ontstaan van ziekten beter 
te begrijpen worden concepten als constitutie en dispositie, die eertijds door de aanhangers van de natuurwetenschappelijke benadering in de geneeskunde als achterhaald waren bestempeld, in ere hersteld en van een nieuwe inhoud voorzien.

Weliswaar hadden sommige natuurwetenschappelijke geneeskundigen, onder wie Virchow, enige waarde gehecht aan dergelijke noties. Constitutie en sociale omstandigheden werden dan naar voren gehaald als voorwaarden waarbinnen het menselijk leven zich afspeelt. Maar de manier waarop in hun ogen deze aspecten geacht werden een rol te spelen in het menselijke fysieke functioneren, verschilde van de opvattingen die daaromtrent rond 1900 naar voren werden gebracht. Virchow vatte, vanuit zijn methodisch materialistisch kader, lichamelijke constitutie en sociale gegevens op als respectievelijk specifieke celfiguraties en bepaalde fysisch en chemisch te reconstrueren invloeden. Dit strookte met de natuurwetenschappelijke benadering van de oorzaken van ziekte, als materiële factoren. Volgens Virchow was het, zoals gezegd, de taak van de arts om ziekte, oftewel leven onder abnormale omstandigheden, te verhelpen door het leven onder normale omstandigheden te herstellen. Dit impliceerde zijns inziens dat de geneeskunde een algemene verbetering van de levensomstandigheden diende na te streven. Medici hadden daardoor ook een politieke taak: de geneeskunde is in zekere zin een sociale geneeskunde (vgl.Virchow, 1849, p. 48). Een dergelijke brede taakstelling van de geneeskunde kon er dus, aldus Virchow, toe leiden dat de gebruikelijke medische handelwijze werd overschreden en de medicus zich in de politiek begaf. Maar de legitimatie hiervan overstijgt het methodisch materialistische kader niet. Ook de politiek actieve arts beperkte zich uiteindelijk tot het manipuleren van materiële omstandigheden.

Aan het begin van de twintigste eeuw trad een verruiming op van de hierboven beschreven, op het methodisch materialisme geschoeide, visie op het menselijk functioneren. De herwaardering van de begrippen constitutie en dispositie vormt daarvan een teken. Met behulp van deze termen kregen aspecten van aanleg en omgeving die niet in materiële gegevens uit te drukken zijn, in toenemende mate een plaats binnen de geneeskunde. Dat betekende dat fysische en chemische omstandigheden niet langer de enige te bestuderen factoren waren, als men wetenschappelijk inzicht wilde verwerven in het menselijke fysieke welzijn. Binnen de medische wetenschap van het begin van de twintigste eeuw werden ook de sociale omgeving en de psychische gesteldheid weer geaccepteerd als aetiologische factor. De opkomst van de psychoanalyse en de sociale geneeskunde en de herwaardering van de psychosomatiek vormen een illustratie van deze ontwikkeling.

De aantasting van de hegemonie van het methodisch materialisme blijkt eveneens uit de verschuivingen in het zelfbeeld van de geneeskunde. De oriëntatie op de fysica, het toonbeeld der natuurwetenschappen, verzwakte. De medische wetenschap profileerde zichzelf in toenemende mate als levenswetenschap en 
spiegelde zich aan de biologie. Het verschil met de opvattingen halverwege de negentiende eeuw blijkt duidelijk in het volgende voorbeeld. In 1851 constateerden Donders en Bauduin, in de inleiding van hun Handleiding tot de natuurkunde van den gezonden mensch bij de verklaring van de opzet van het boek, dat het woord biologie, als levensleer, wellicht een betere benaming voor hun onderneming zou zijn geweest dan fysiologie, natuurleer of natuurkunde. Fysiologie wordt namelijk zelfs wel gebruikt in de zin van leer van de dode natuur, zo stelden zij. Maar zij zagen er vervolgens toch van af de term biologie te bezigen, omdat dit begrip als alternatief voor fysiologie niet algemeen ingang had gevonden (vgl. Donders \& Bauduin, 1851, pp. 1-2). Het feit dat het in dit type natuurkunde om levende objecten gaat, leidde niet tot een nuancering in het begrippenapparaat. Rond de eeuwwisseling was de situatie echter volledig anders: alom werd de geneeskunde tot een biologische wetenschap verklaard.

Vanwege deze oriēntatie op de biologie zijn de toenmalige ontwikkelingen in de wijsgerige biologie van belang om een goed beeld van de geneeskunde tussen 1890 en 1940 te verkrijgen. Zij worden hieronder dan ook mede in de bespreking betrokken. In de periode die in dit hoofdstuk aan de orde wordt gesteld, was er in de wijsgerige biologie sprake van een wederopbloei van vitalistische en organicistische denkbeelden. Aan het werk van de voornaamste vertolker van het neo-vitalisme H. Driesch (1867-1941), hoogleraar filosofie te Leipzig, werd ook in medische kring ruim aandacht geschonken. Diens theorieën werden zelden integraal overgenomen, maar velen putten inspiratie uit zijn ideeën als het ging om een specifieke waardering van de levende natuur (vgl. o.a. Tendeloo, 1922, p.17). In de jaren twintig en dertig van de twintigste eeuw werd ook het werk van andere organicistisch georiënteerde theoretische biologen als J. S. Haldane (1860-1936) en J. von Uexküll (1864-1944) door artsen met waardering besproken.

In de theoretische biologie werd toentertijd het principiële verschil tussen levensverschijnselen en fysisch-chemische verschijnselen verder uitgewerkt. Organismen en dingen kunnen beide weliswaar als een mechanisme worden opgevat, zo stelde men, maar een dergelijke beschouwingswijze schiet altijd tekort ten aanzien van de organismen (vgl. o.a. Haldane, 1923; Haldane 1931; Von Uexküll, 1928). Het vermogen van de levende natuur, en dus ook van de mens, om te reageren op vreemde invloeden door wijzigingen in functie en organisatie, wijst op een bepaalde ordening die niet alleen door causale wetmatigheden wordt verklaard. De genoemde biologen hielden een pleidooi om in de wetenschap wel recht te doen aan de specifieke kwaliteiten van de levende natuur.

Met de beoogde waardering van de eigen aard van de levende natuur hangt de opkomst van de stroming van het holisme in de biologische wetenschappen samen. In deze visie worden de verschijnselen in de levende natuur niet beschouwd als opdeelbaar in talloze sequenties van actie en reactie, maar ze worden gezien vanuit een integraal concept, als actieve manifestaties van een 
levend organisme (vgl. o.a. Haldane, 1931, p. 14). De door het holisme beinvloede wijsgerig biologen stelden dat organismen in een louter analyserende beschouwingswijze niet tot hun recht kunnen komen. Het functioneren van een levend organisme is niet louter een ingewikkelde optelsom van wetenschappelijk te onderscheiden processen en mechanismen. Zij beklemtoonden dat binnen de levende natuur een leidende rol wordt gespeeld door specifieke richtinggevende factoren, zoals een zekere algemene planmatigheid en een vermogen tot organisatie en integratie. Verschijnselen als regeneratie en aanpassing vormden naar hun oordeel belangrijke onderzoeksthema's. Deze voor de levende natuur juist zo karakteristieke kenmerken laten zich niet reduceren tot natuurkundige wetten. Natuurwetenschappelijke causale analyses zijn in deze gevallen niet toereikend, zo stelde men, en daarom moeten ze worden aangevuld met verklaringen die daarmee wel rekening hielden.

Onder invloed van de ontwikkelingen in de wijsgerige biologie werd het ideaal van de eenheid van de wetenschappen, die zich alle baseren op het methodisch materialisme van de natuurwetenschap, door velen verlaten. In plaats van een concept van de natuur ten opzichte waarvan slechts één type wetenschap mogelijk is, wordt er een principiële scheiding tussen levende en dode natuur aangebracht. Hieraan werd vervolgens de consequentie verbonden dat er verschillende typen wetenschap zijn, enerzijds de levenswetenschappen en anderzijds de natuurwetenschappen in klassieke zin. Door sommigen werd daarnaast ook een speciale categorie ingeruimd voor de menswetenschappen (vgl.Verwey, 1988, pp. 62 e.v.).

In het verlengde van de geschetste wijsgerig biologische discussies vond het standpunt dat er eveneens een wezenlijk verschil bestaat tussen de geneeskunde en de natuurwetenschappen, steeds meer aanhang. Het onderscheid tussen levende en dode natuur was niet alleen voor de biologie maar ook voor de medische wetenschap relevant. Het eigen karakter van de levensverschijnselen dat eertijds vanuit een methodisch materialistische visie werd genegeerd, verdiende erkenning binnen de medische wetenschap, zo meende men. Men beschouwde in toenemende mate de geneeskunde als een levenswetenschap, evenals de biologie.

Deze herdefiniëring vertoont twee aspecten. Enerzijds trad er een belangrijke wijziging op in het denken over het object van de geneeskunde, de mens. De mens werd in toenemende mate opgevat als een organisme en niet langer louter als een zeer gecompliceerd mechanisme. Men beklemtoonde dat het nieuwe uitgangspunt voor de geneeskunde moest luiden dat de mens een deel van de levende natuur is. Op zich was dit geen principieel nieuw of revolutionair standpunt. In de natuurwetenschappelijke geneeskunde van de tweede helft van de negentiende eeuw verschafte de celtheorie immers een basis voor het onderscheid tussen levende en dode natuur. Vanuit de methodische instelling van de 
zich als natuurwetenschap definièrende geneeskunde werden er echter geen verdere consequenties verbonden aan dit verschil. Integendeel, de levende en dode natuur werden, zoals in het voorgaande hoofdstuk is aangegeven, vanuit wetenschappelijk opzicht op één lijn geplaatst. Ten tijde van de wending naar de levenswetenschappelijke opvatting van de geneeskunde raakten medici er evenwel van overtuigd dat celprocessen en orgaanfuncties niet gelijkgesteld moesten worden met overige fysische en chemische processen. Essentieel voor deze levensprocessen is immers dat zij in dienst staan van het functioneren van het organisme als geheel. Een consequentie van dit gezichtspunt was dat de pathologie haar aandacht verlegde van afzonderlijke cellulair gefundeerde ziekteprocessen naar het zieke organisme als geheel. Uiteindelijk resulteerde dit in uiteenlopende vormen van holistische pathologie (vgl. Mayer, 1953, pp. 73 e.v.).

De toenadering tot de biologie leidde anderzijds tot gewijzigde inzichten over de te hanteren verklaringswijze. Aan de wijsgerige bespiegelingen omtrent de aard van het object verbond men op methodologisch niveau de conclusie dat de mechanicistische en reducerende benadering van de natuurwetenschappen niet voldoet in de geneeskunde, omdat hierdoor wezenlijke eigenschappen van het organisme uit het zicht verdwijnen. De Nederlandse hoogleraar in de keel-neus en oorheelkunde H. Burger (1864-1957) constateerde bijvoorbeeld het volgende: "Men ontkomt niet aan den indruk, dat, naast het mechanisch gebeuren, een eigen regelende natuurfactor aan het werk is. (...) De in de orgaan-determinatie nagespeurde wetmatigheid als zoodanig is voor een mechanistische verklaring ontoegankelijk" (Burger, 1928, p. 448). Dergelijke overwegingen leidden ertoe dat mechanistische verklaringen niet zozeer werden verworpen, als wel dat men meende dat ze aanvulling behoeven.

Opmerkelijk is dat in de levenswetenschappelijk georiënteerde periode filosofische inzichten een andere positie innemen ten opzichte van de wetenschap, dan tevoren. Zij kunnen criteria verschaffen op grond waarvan methodologische regels worden bekritiseerd. Het onderscheid tussen levende en dode natuur werd geacht implicaties te hebben voor de wetenschappelijke verklaringswijze. Dit standpunt verschilt wezenlijk van de verhouding tussen filosofie en wetenschap in de natuurwetenschappelijke geneeskunde: beide werden eertijds strikt gescheiden gehouden. Het methodisch materialisme beroemde zich erop geen uitspraken te doen op ontologisch niveau, de structuur van de werkelijkheid zou er niet door worden vastgelegd. In de daaropvolgende discussies bleek het methodisch materialisme toch op een bepaalde vooronderstelling over de werkelijkheid te berusten, namelijk dat via deze methoden zinvolle kennis van die werkelijkheid kan worden verworven. Juist op dit punt, dat wil zeggen op haar impliciete wereldbeeld, werd de natuurwetenschappelijke conceptie van geneeskunde bekritiseerd. Men kwam tot de conclusie dat een zekere vermenging van wetenschap en metafysica, zij het op het niveau van de grondslagen van de 
wetenschap, onontkoombaar is. Deze vervlechting werd niet langer als funest beschouwd voor de wetenschap; ze werd niet langer krachtig bestreden. De vermenging van wetenschap en wijsbegeerte, die in de tweede helft van de negentiende eeuw met zoveel nadruk werd afgewezen, verscheen derhalve aan het begin van de twintigste eeuw opnieuw op het toneel. Filosofische vragen werden niet langer verbannen buiten het gezichtsveld van de wetenschapsbeoefenaars. Aan de reflectieve inzichten omtrent het object van de medische wetenschap worden tevens methodologische consequenties verbonden.

De natuurwetenschappelijke benadering werd in de periode waarin de levenswetenschappelijke opvattingen naar voren komen, overigens ook in bredere zin bekritiseerd. $\mathrm{Zij}$ zou bijdragen aan een algemeen proces van vervreemding en fragmentatie. Door het gebruik van causaal-analytische onderzoeksmethoden levert dit type wetenschap slechts losstaande feiten, klaagde men (vgl. Paulsen, 1906, pp. 66-67. geciteerd in Leichtman, 1979, p. 58). Een integrerende visie werd node gemist. De nieuwe levenswetenschappelijke vormen van geneeskunde zouden volgens sommigen ook beter te rijmen zijn met levensbeschouwelijke opvattingen terwijl de mechanistische natuurverklaring anti-godsdienstige trekken zou vertonen en gemakkelijk zou leiden tot atheisme en materialisme (vgl. Van de Bom, 1933a; Van de Bom, 1933b: Bruna, 1935b). Dergelijke kritiek heeft ook de weg vrijgemaakt voor de vermenging van filosofische en levensbeschouwelijke motieven met de wetenschappen, die in de levenswetenschappelijke oriëntatie kan worden aangetroffen.

In de geneeskunde rond de eeuwwisseling kan men, evenals in de biologie, een opmerkelijke rehabilitatie van het teleologische denken constateren. Werd enkele decennia tevoren het teleologisch denken met kracht bestreden, nu trad het naar voren als een oplossing voor vragen die vanzelfsprekend voortkomen uit de bestudering van het leven. De levende natuur vertoont niet alleen een vermogen tot organisatie en integratie, zo stelde men, maar daarmee ook een bepaalde doelgerichtheid. Daarom zou de geneeskunde onvolledig en inadequaat zijn als ze geen acht slaat op de doelmatigheid in de levende natuur. De veranderingen in functie, organisatie en vorm, die het organisme ondergaat ten gevolge van vreemde invloeden, kunnen niet alleen als causale processen worden geduid. Vorm en functie moeten in hun relatie met de omgeving worden bekeken. Ten aanzien van levende wezens moet men, behalve met de causale afhankelijkheidsrelaties, ook rekening houden met een andere vorm van afhankelijkheid: tussen de delen en het geheel, tussen de organen en het organisme, tussen individuele verschijnselen en het leven als geheel. Dit alles werd aangeduid met het begrip "doelafhankelijkheid". De mens moest volgens deze teleologische opvatting niet opgedeeld worden. Hij behoorde juist als een georganiseerd geheel, functionerend in een bepaalde omgeving, te worden gezien. 
Kenmerkend voor de natuurwetenschappen was dat het object van de wetenschap werd beschouwd als één element uit een verzameling van gelijksoortige elementen. De zin van de nomothetische benadering van de natuurwetenschap berust op deze veronderstelling. Aan de hand van de overeenkomsten tussen de afzonderlijke elementen kunnen wetenschapsbeofenaars verklaringen geven en voorspellingen doen. Deze aanname vindt men ook terug in de geneeskunde, die het natuurwetenschappelijk wetenschapsideaal overneemt. In het vorige hoofdstuk bleek dit onder andere in Bernards overtuiging dat een arts, zodra hij de determinerende oorzaken van een ziekte kent en weet hoe deze verholpen moet worden, op grond van zijn kennis deze ziekte altijd zal kunnen verhelpen (vgl. Bernard, 1865, pp. 374 e.v.).

In de levenswetenschappelijke periode vindt op dit punt een belangrijke omslag plaats. In plaats van uit te gaan van gelijkvormigheid, beklemtoonde men het individuele karakter van het organisme. De Berlijnse hoogleraar interne geneeskunde Fr. Kraus (1858-1936) wilde in zijn bekende werk Die allgemeine und sperielle Pathologie der Person. Klinische Syzygiologic het belang van een synthetiserende benadering, waarin het menselijk organisme als een individuele functionele eenheid wordt gezien, voor het voetlicht halen (Kraus, 1919). In de jaren twintig is het accent verder verschoven. De nadruk kwam hoe langer hoe meer te liggen op de individualiteit van de persoon. Deze ontwikkeling wordt in het volgende hoofdstuk nader toegelicht.

Een belangrijk kenmerk van de levenswetenschappelijke ommezwaai in de geneeskunde was voorts dat theorie en praktijk tegenover elkaar worden uitgespeeld. De argumenten ten gunste van een organicistische, holistische of teleologische benadering in de geneeskunde steunden niet zozeer op een hang naar wetenschappelijke zuiverheid. Ze ontleenden hun kracht vooral aan de wens recht te doen aan de medische praktijk. Deze confrontatie tussen wetenschap en praktijk komt zowel in de discussies rond het ziektebegrip als bij de bespreking van het klinisch oordeel naar voren. In de natuurwetenschappelijke geneeskunde werden theorie en praktijk daarentegen nauw verbonden geacht. De praktijk zou idealiter bestaan uit de toepassing van de geneeskundige wetmatigheden en ontleende haar rationaliteit aan de toepassing van de theorie. In de levenswetenschappelijke periode werd echter gesteld dat de uitoefening van de geneeskunde meer vereist dan louter toepassing van wetten. Men heeft immers met individuele personen te maken. Dit surplus moest worden verdisconteerd in een adequate omschrijving van de geneeskunde. 
De kritiek op het natuurwetenschappelijk concept van de geneeskunde strekte zich ook uit tot haar visie op de arts-patiënt relatie. De door de natuurwetenschappelijke geneeskunde voorgestane objectiverende houding van de arts ten opzichte van de zieke werd geproblematiseerd. Tegenover een dergelijke afstandelijke relatie werd door artsen als E. Schweninger (1850-1923), G. Honigmann (1863-1930) en Richard Koch gewezen op de noodzakelijke betrokkenheid van de arts bij de patiënt (Schweninger, 1907: Honigmann, 1913; Koch, 1917; Koch, 1923; Koch, 1926). De medische relatie is, zo betoogden zij, fundamenteel verschillend van de relatie van een wetenschapsbeoefenaar tot zijn object. De subject-object relatie kan daarvoor niet model staan. Als de natuurwetenschappelijke geneeskunde een dergelijke relatie wel als voorbeeld ziet van de verhouding tussen arts en patiënt, dan is er iets fundamenteel mis met haar visie op de medische praktijk. De natuurwetenschap kan op dit essentiēle punt niet fungeren als wetenschapsideaal, zo stelde men. De praktische geneeskunde is niet gebaseerd op waardevrijheid en distantie, maar op betrokkenheid. Een geldige conceptie van geneeskunde dient dit gegeven in zich op te nemen.

De natuurwetenschappelijk oriëntatie van de geneeskunde raakte rond de eeuwwisseling steeds meer aan het wankelen. De opvatting dat aandacht voor de individualiteit van organismen hemelsbreed verschilt van de in de natuurwetenschappelijke geneeskunde als vanzelfsprekend aanvaarde gelijkheid van alle individuen in geval van ziekte, won terrein. Het methodisch materialisme werd verlaten, de gelijkschakeling van dode en levende natuur werd bestreden. Het wetenschapsmodel waarnaar de geneeskunde zich richtte was de biologie. De strenge scheiding tussen wetenschap enerzijds en filosofie en levensbeschouwing anderzijds werd versoepeld. Aan wijsgerige inzichten worden consequenties verbonden ten aanzien van de wetenschappelijke verklaringswijze. Zowel de rehabilitatie van de finale of teleologische beschouwingswijze binnen de wetenschap, als de oriêntatie op de praktijk zijn de opvallende kenmerken van de nieuwe oriëntatie binnen de geneeskunde.

In de volgende twee paragrafen zullen de consequenties van deze veranderingen voor het ziektebegrip en het klinisch oordeel worden besproken. De laatste paragrafen van dit hoofdstuk zijn gewijd aan de opvattingen van twee vooraanstaande Nederlandse medici ten tijde van de levenswetenschappelijke oriēntatie in de geneeskunde. Eerst worden de ideeēn van Winkler, die vanaf in de jaren negentig van de negentiende eeuw als hoogleraar psychiatrie werkzaam was, weergegeven. Vervolgens wordt aandacht geschonken aan de anatoom Barge en diens receptie van de levenswetenschappelijke opvatting van de geneeskunde in de jaren twintig en dertig van de twintigste eeuw. 


\subsection{Ziekte als disfunctie}

De herdefiniëring van geneeskunde als natuurwetenschap tot geneeskunde als levenswetenschap impliceerde een heroverweging van het ziektebegrip. Dit centrale concept heeft in de periode van de jaren negentig van de negentiende eeuw tot de jaren dertig van de twintigste eeuw dan ook belangrijke wijzigingen ondergaan. Van deze ontwikkelingen zal in deze paragraaf een overzicht worden gegeven.

In de nieuwe omschrijving van het begrip "ziekte" werd het gerelateerd aan het totale functioneren van het individuele organisme. Ziekte werd gezien als een verstoring van het normale functiepatroon, als een inadequate en/of verminderde prestatie, kortom als disfunctie. De individualiteit van de patiënt en van zijn ziekte kwamen meer op de voorgrond te staan dan in de voorafgaande periode. Het resultaat was dat de cellulaire pathologie, maatgevend toen de natuurwetenschappelijke oriëntatie in de geneeskunde hoogtij vierde, door de constitutiepathologie en de functionele pathologie van haar troon werd gestoten.

In de laatste twee decennia van de negentiende eeuw werd de eerste serieuze aanval op de cellulaire pathologie ondernomen door de aanhangers van de bacteriologische school. Zij meenden, in het voetspoor van Robert Koch (18431910), dat het voor de pathologie van veel meer belang is om te zoeken naar uitwendige oorzaken van ziekte, dan om cellulaire processen te ontrafelen. Diens onderzoek naar de aetiologie van wondinfecties, tuberculose en miltvuur had immers aangetoond dat het mogelijk is bepaalde welomschreven ziekteverwekkers aan te wijzen (o.a. Koch, 1876; Koch, 1878; Koch 1932 (1882)). Ziekte werd door de bacteriologische school opgevat als de strijd tussen de cel en een microorganisme. E. Klebs (1834-1913), naast Koch één der belangrijkste woordvoerders van deze school, verdedigde de claim dat de uitwendige oorzaak, i.c. een parasitair micro-organisme, het grootste gewicht in de schaal legt bij het verloop van een ziekte (vgl. Diepgen, 1926, p. 312 e.v.). Men koesterde na Kochs ontdekkingen zelfs de verwachting dat het eens mogelijk zal zijn om één tastbare externe factor, zoals een bacterie, te identificeren als dé oorzaak van een specifieke ziekte. Vandaar dat de bacteriologen zich sterk toelegden op "Ursachenforschung", onderzoek naar ziekteverwekkers (vgl. Klebs, 1887).

Voor wat betreft hun wetenschapsopvatting passen de bacteriologen geheel binnen het kader van de natuurwetenschappelijke geneeskunde. Zij zochten naar bepaalde specificeerbare causale verbanden, die het optreden van een ziekte verklaren. Zeer uitdrukkelijk onderschreven zij het methodologisch materialisme en het experimentele karakter van de natuurwetenschappen. De bacteriologen 
gingen ervan uit dat er uiteindelijk één factor aanwijsbaar zal zijn die het optreden van een ziekte bepaalt. Deze reductie van een causale verklaring tot een mono-causaal verband, leidde tot een wat naief optimisme. Het verhelpen van ziekte werd gelijkgesteld met de jacht op afzonderlijke belagers van onze gezondheid. Door deze ene factor op te sporen en te bestrijden zou men ziekte kunnen afweren en bestrijden. Opmerkelijk is dat dergelijke ideeën verwantschap vertonen met denkbeelden die, zoals we in het vorige hoofdstuk hebben geschetst, waren verbonden met een ontologisch ziektebegrip. Dat klinkt ook door in de terminologie. Door de bacteriologen werd het parasitaire microorganisme beschreven als "de boosdoener", terwijl de aanwezigheid van dergelijke micro-organismes gelijkgesteld werd met ziekte.

In zijn geschrift Hundert jahre allgemeiner Pathologie uit 1895 heeft Virchow, ondanks zijn gevorderde leeftijd, de bacteriologie en haar aanspraken besproken (Virchow, 1895, pp. 37 e.v.). Hij verdedigde zijn cellulaire pathologie door de bacteriologen te verwijten dat ze ziekte identificeren met een bepaalde ziekte-oorzaak. "Ens morbi", het wezen van de ziekte, door Virchow als een celproces aangeduid, en "causa morbi", de ziekte-oorzaak, werden zijns inziens door de bacteriologen al te gemakkelijk met elkaar verwisseld. "Ein wirklicher Parasit, mag er nun Thier oder Pflanze sein, kann die Ursache einer Krankheit werden, aber niemals stellt er die Krankheit selbst dar", aldus Virchow (ibid., p. 38). Deze verwarring had volgens Virchow ongewenste consequenties. In het verlengde van deze verwisseling stelden de bacteriologen namelijk de aanwezigheid van parasitaire microorganismen gelijk met ziekte en afwezigheid van micro-organismen met gezondheid. Virchow wees erop dat deze gelijkstelling strijdig is met de praktijk, waarin wij constateren dat talloze mensen weliswaar drager zijn van bacteriën, maar toch allerminst ziek zijn. Hij stelde daartegenover dat ziekte ontstaat in de strijd van de cellen met de bacteriën. Ziekte kan wel een gevolg zijn van het binnendringen van micro-organismen, maar er zijn ook andere factoren op van invloed. Binnen het bacteriologisch perspectief figureert het parasitaire organisme echter als enige relevante ziekte-oorzaak. Zo wordt het gemakkelijk tot het wezen van de ziekte verheven. De stap van de bacterie als een noodzakelijke voorwaarde bij het optreden van ziekten, naar de bacterie als voldoende voorwaarde, blijkt snel gezet. Bestrijding van ziekte zou in een dergelijke visie gelijkstaan met het bestrijden van de bacterie. Het belang van andere factoren wordt hiermee ontkend. Naast deze fundamentele kritiek werd door Virchow de vraag opgeworpen, of er inderdaad pathogene micro-organismen ten grondslag liggen aan elke zich als besmettelijk voordoende ziekte. Het is niet wetenschappelijk vastgesteld of er ook besmettingen zonder bacteriën voorkomen, zo stelde hij (ibid., p. 39). 
In zijn kritiek op de bacteriologie legde Virchow de vinger op een punt dat in de volgende decennia in belangrijke mate zou bijdragen tot een relativering van de natuurwetenschappelijke geneeskunde. Hij laat immers zien dat het optimisme ten aanzien van de opsporing van ziekte-oorzaken moet worden getemperd. Ziekteprocessen kunnen zeer wel het gevolg zijn van een besmetting door parasitaire micro-organismen, maar zij zijn er niet het noodzakelijke gevolg van. Met andere woorden, de aanwezigheid van bacteriën vormt niet een voldoende voorwaarde voor het optreden van ziekte. De grens tussen ziek en gezond blijkt niet getrokken te kunnen worden op grond van een dergelijke objectieve, algemeen geldende maatstaf. De relevantie van de uitwendige ziekte-oorzaak, de "causa externa", is weliswaar niet te loochenen, maar er zijn meerdere factoren in het geding bij het ontstaan van ziekten, zoals Virchow aangaf. De erkenning hiervan leidde ertoe dat men zich in het medisch wetenschappelijk onderzoek in toenemende mate richtte op individuele kenmerken, zoals de innerlijke gesteldheid van het organisme.

Deze aandacht voor individuele factoren betekende een belangrijke ommezwaai ten opzichte van de natuurwetenschappelijke geneeskunde. In het voorgaande hoofdstuk is beschreven dat één van de fundamentele vooronderstellingen daarvan de onderlinge menselijke gelijkheid is. Men ging er van uit dat elk mens onder identieke omstandigheden op dezelfde manier zal reageren. En bovendien waren mensen vanuit het perspectief van de natuurwetenschappelijke geneeskunde alleen interessant op het niveau van hun materiële functioneren. De fysische en chemische wetmatigheden die dit functioneren beheersen, hebben op iedereen betrekking, zonder onderscheid des persoons. Zoals in de vorige paragraaf al is aangehaald, werden de begrippen "constitutie" en "dispositie" in de natuurwetenschappelijk gedefinieerde geneeskunde dan ook nutteloos geacht. Daarenboven hadden deze begrippen een ouderwetse, normatieve en zelfs "ondemocratische" bijklank. Ze behoorden meer bij de oude plattelandsarts, die niet geschoold was in de moderne objectieve, empirisch wetenschappelijke geneeskunde.

Rond de eeuwwisseling werd aan deze obsoleet geachte concepten constitutie en dispositie opnieuw inhoud en gewicht gegeven (vgl. o.a. Diepgen, 1926, p. 327). Het aan de klinische praktijk ontleende inzicht dat elke patiēnt verschillend reageert op dezelfde schadelijke invloed, werd niet langer als een gedateerde vuistregel beschouwd. In de geneeskunde worden juist de individuele eigenschappen van het organisme, die bepalend zijn voor de reactie van het organisme op de omgevingsinvloeden, beklemtoond (vgl. Bieganski, 1909. p. 88). In de overgangsfase van een natuurwetenschappelijk naar een levenswetenschappelijk georiënteerde geneeskunde, probeert de energetistische school van onder anderen Fr. Martius (1850-1923) en F. Hueppe (1852-1913), die 
assistent geweest was van Robert Koch, de importantie van de individuele verschillen te verzoenen met een uitgesproken natuurwetenschappelijke opvatting van de geneeskunde. Aanhangers van deze school lieten zich inspireren door de wet van behoud van energie. De aantrekkingskracht van deze natuurkundige wet bestond eruit dat zoveel op het eerste gezicht onderscheiden krachten daardoor onder één noemer kunnen worden gebracht, namelijk energie. Ten aanzien van de diverse factoren in het ontstaan en verloop van ziekte verwachtten zij eenzelfde procedure te kunnen toepassen. Deze worden alle, inclusief de menselijke constitutie en dispositie, geherformuleerd in termen van energie. Een Nederlandse onderzoeker die zichzelf aan het begin van deze eeuw onder de energetici schaarde, is de Utrechtse hoogleraar in de fysiologie H. Zwaardemaker (18571930) (vgl. o.a. Zwaardemaker, 1910).

De energetistische school bestreed de bacteriologische stelling dat micro-organismen de noodzakelijke en voldoende voorwaarde, oftewel de oorzaak, voor infectieziekten zouden zijn. De aard van het getroffen organisme en de omstandigheden waarin de besmetting tot stand komt zijn ook van wezenlijk belang. Artsen die zich bezighouden met het verklaren van ziekte, moesten zich volgens Martius in eerste instantie richten op de constitutie. In het licht van de individuele constitutie kan men dan ook eigenlijk niet spreken van dé oorzaak van ziekten. Er is veeleer sprake van een samenspel van voorwaarden (Martius, 1923. p. 24 (p. 128)) .

De aanhangers van de energetistische school bekommerden zich zeer om het wetenschappelijk gehalte van hun theorieën. Zij koesterden de verwachting dat als alle mogelijke factoren die het optreden en het verloop van het ziekteproces bepalen in termen van energie worden geherformuleerd, zowel het wetenschappelijk karakter van de geneeskunde gegarandeerd zal zijn als de mogelijkheid om op individueel niveau aan allerlei verschillende invloeden recht te doen (Hueppe, 1923; Martius, 1923; Diepgen, 1926, pp. 316 e.v.). Biologische én sociale bepaaldheden, erfelijke en functionele eigenschappen, werden door hen beschouwd als latente voorwaarden bij het optreden van ziekte. Constitutie en dispositie werden vervolgens gekwalificeerd als potentiële energie. Het feitelijk optreden van ziekte wordt veroorzaakt, volgens de energetici, doordat op een bepaald moment de energiebalans wordt verstoord. De relatie tussen aanleiding en uitwerking bij ziekte wordt aldus gebaseerd op de overdracht van energie. Hierdoor werd het mogelijk om bijvoorbeeld het natuurwetenschappelijke dogma dat oorzaak en gevolg evenredig moeten zijn, "causa aequat effectum", te behouden in de geneeskunde.

Het energetisme beschouwde in feite niet alleen ziekteprocessen maar het gehele leven als een voortdurende uitwisseling van energie. Alle individuele verschillen werden vertaald in specifieke hoeveelheden energie. Dat leidde ook tot een specifieke opvatting van organismen. G. Graul, een aanhanger van Martius, 
formuleerde dit als volgt: "Der Organismus bildet eine große funktionelle Finheit, alle Organsysteme stehen in ständiger energetischer, Reaktionen auslösender Wechselbeziehung zueinander, (...)" (Graul, 1917, p. 1541). Ziekte werd gezien als de functie van aanleg, constitutie en dispositie, uitwendige omstandigheden en een prikkel, bijvoorbeeld in de vorm van een micro-organisme, waardoor de spanning wordt geactualiseerd (vgl. Hueppe, 1923, p. 16). Het energetisme herleidde zo ziekteprocessen tot energieprocessen en reduceerde alle voor de pathologie relevante begrippen tot kwantitatieve grootheden, tot hoeveelheden energie. Dit betekent dat de pathologie uiteindelijk werd gelijkgesteld aan een rekenmodel.

Evenals de eerdere aanhangers van de natuurwetenschappelijke geneeskunde legden de energetici er de nadruk op dat ziekte geen statisch gegeven is. Ziekte en gezondheid worden beide gezien als bepaalde vormen van causaal functioneren, waarbij het abnormale functioneren als ziekte geldt. Graul drukte dit als volgt uit: "(...) stets ist Krankheit der Ausdruck funktioneller Disharmonien nach irgendeiner Richtung hin." (Graul, 1917, p. 1542). Ziekte wordt volgens deze opvatting gekenmerkt door de ondoelmatigheid voor het organisme, er is afgeweken van de normale neiging tot doelmatigheid (vgl. ibid., p. 1568). Zwaardemaker betitelde ziekten als stoornissen in de harmonische zelfregeling van individuele organismen. Deze harmonische zelfregeling beschreef hij als een open systeem, “(...) waar voortdurend allerlei vormen van energie in zeer wisselende hoeveelheden toe- en afvloeien" (Zwaardemaker, 1910, p. 16). Ook de dood werd door hem in deze termen begrepen: "Ja, in die mate beheerscht het beginsel der harmonische zelfregeling geheel ons leven, dat hetgeen wij gewoon zijn als den dood van het physiologisch individu te beschouwen, in werkelijkheid het eindigen zijner zelfregeling is" (ibid., p. 20). Overigens kan men zich afvragen of een onderzoeker, die zich richt op de overdracht van energie, wel in staat is om disharmonieën te ontdekken. In de kwaliteitsloze, kwantitatieve wereld van de energetica hebben concepten als doelmatigheid en (ab)normaal functioneren eigenlijk geen betekenis. Het was niet consequent om in het kader van een energetische geneeskunde deze begrippen te hanteren.

De bacteriologie en het energetisme hebben achtereenvolgens elk een met de negentiende-eeuwse opvatting van de natuurwetenschappelijke geneeskunde verbonden principe verabsoluteerd. In de bacteriologie werd de lineaire, monocausale verklaring tot maatgevend voorbeeld. Voor het optreden van ziekten werd één factor verantwoordelijk gesteld, de bacterie, terwijl het uit de praktijk bekende gegeven dat het optreden van ziekte verband houdt met constitutie en dispositie werd genegeerd. Het energetisme vormde vervolgens een strikt doorgevoerde vorm van reductionisme. Het trachtte de verschillende omstandigheden die van belang zijn bij het optreden van ziekte recht te doen, door elke factor in het ziekteproces te reduceren tot een hoeveelheid potentiële energie. 
Op deze wijze culmineerde het streven naar natuurwetenschappelijke zuiverheid aan het begin van de twintigste eeuw in een van elke kwaliteit abstraherende, energetische opvatting van geneeskunde. Elke basis voor de geneeskunde als aparte tak van wetenschap leek, na de aanval op de cellulaire pathologie door de bacteriologie en de daaropvolgende relativering van de bacteriologie door de energetische school, weggevallen te zijn. Door de energetische beginselen te volgen viel de geneeskunde samen met de fysica en verloor ze haar eigen identiteit. In haar zoektocht naar wetenschappelijke rationaliteit was de geneeskunde gedwongen één van haar basisconcepten prijs te geven. Het begrip "ziekte" had binnen het kwaliteitsloze energetisme elke inhoud verloren: het was opgelost in de continue stroom van energie-overdracht (vgl. Widdershoven-Heerding. 1990 , pp. 57-58).

Deze consequenties van het energetisme werden vrijwel gelijktijdig met haar opkomst ter discussie gesteld. Tekenend voor dit debat is dat het energetisch ziektebegrip niet zozeer op theoretisch niveau werd bekritiseerd, maar dat er aan de praktijk van de geneeskunde een aparte betekenis werd toegekend. Men bekommerde zich daarbij minder om het wetenschappelijk gehalte van de geneeskunde dan voorheen het geval was. In het tijdperk van de natuurwetenschappelijk gedefinieerde geneeskunde werden, zoals we hebben gezien, theorie en praktijk geacht één te zijn: de kracht van de praktijk vloeide direct voort uit de sterkte van de wetenschap. Aan het begin van de twintigste eeuw worden theorie en praktijk echter tegenover elkaar gesteld. In deze confrontatie kunnen de eisen van de medische praktijk de theoreticus op legitieme wijze dwingen afstand te nemen van zijn op zich wetenschappelijk verantwoorde uitgangspunten.

O. Lubarsch (1860-1933), hoogleraar algemene pathologie en pathologische anatomie en redacteur van verschillende handboeken en vaktijdschriften, levert een goed voorbeeld van een dergelijke vorm van kritiek. In zijn oratie te Berlijn in 1917 onderschreef hij Virchows stelling dat ziekte niet anders is dan leven onder veranderde omstandigheden. Daarbij tekende hij aan dat leven, ook het gezonde leven, een voortdurend proces van opbouw en afbraak, van ontstaan en vergaan is. Ziekte is slechts een relatief begrip en niet wezenlijk verschillend van gezondheid. Ziekte behelst de verstoring van een bepaalde evenwichtstoestand, die bij gezondheid gehandhaafd blijft door de onmiddellijke verwerking van wijzigingen in de levensomstandigheden (vgl. Lubarsch, 1917, p. 1378). Een verdere doordenking van de consequenties van een dergelijk ziektebegrip bracht Lubarsch er in 1919 toe om de louter kwantitatief gerichte, energetische uitwerking van deze principes af te wijzen. Zijn argument luidde dat de eisen van de praktijk zich er niet mee laten verenigen. Hij gaf aan dat de geneeskunde niet verder wordt gebracht door de ideeën van Martius en de zijnen. Integendeel, door te stellen dat alles met alles samenhangt in een groot causaal netwerk, 
verliest een nuttig begrip als ziekteoorzaak zijn inhoud, aldus Lubarsch (vgl. Lubarsch, 1919a, pp. 1 e.v.). Hij verweet Martius een "zuiver conditionalisme". omdat in diens optiek bij de verklaring van het optreden van ziekte of dood alle voorwaarden even noodzakelijk en gelijkwaardig zijn (vgl. Lubarsch, 1919b, p. 35). Martius' uitspraken, "Die Ursache der Krankheit ist der Mensch" en "Die Ursache des Todes ist das Leben", kunnen volgens Lubarsch geen houvast bieden voor de pathologie. In de praktijk bestaat er behoefte aan meer specifieke oorzaken. Door de arts wordt vanuit een bepaalde situatie in het bijzonder naar deze oorzaken gevraagd, met de bedoeling greep te krijgen op deze situatie.

De bacteriologie en het energetisme hebben geen van beide lange tijd het zelfbeeld van de geneeskunde beheerst. In de jaren tien van de twintigste eeuw werden met name de geschriften van Martius regelmatig aangehaald als verdienstelijke pogingen om een constitutie-pathologie te funderen, maar daarna raakte het energetisme op de achtergrond. Beide stromingen hebben volgens de kritiek te weinig oog voor de praktijk. Er werd naar voren gebracht dat dergelijke uitwerkingen van een natuurwetenschappelijke geneeskunde geen bevredigend kader verschaffen, waarbinnen voor de uitoefening van de geneeskunde belangrijke begrippen een zinvolle plaats hebben. Medisch onderzoek is juist geinteresseerd in de waardering van de verschillende omstandigheden die zich voordoen bij ziekte en dood. Men wil daarenboven inzicht krijgen in de vraag waarom de ene toestand wel en de andere niet als vorm van ziekte moet worden gekwalificeerd. Met andere woorden, men stelde dat men in de medische praktijk behoefte heeft aan kwalitatieve beoordelingsmaatstaven.

Zoals in de vorige paragraaf is aangegeven, wendde de geneeskunde zich langzamerhand tot een ander wetenschapsconcept. De natuurwetenschappelijke oriëntatie binnen de geneeskunde raakte steeds meer op de achtergrond. Het mechanistische denken verloor aan aanzien ten gunste van een biologisch getint concept van geneeskunde: de geneeskunde profileerde zich als levenswetenschap. Virchows uitspraak dat ziekte "leven onder gewijzigde omstandigheden" is, werd ook in het begin van de twintigste eeuw met instemming geciteerd. Men benadrukte dan in deze formulering het aspect van leven, terwijl Virchow met deze karakterisering er op doelde dat ziekte, evenals andere vormen van leven, een proces is dat met behulp van fysische en chemische wetmatigheden is te vatten. Virchow lichtte in 1895 zijn natuurwetenschappelijk gefundeerde ziektebegrip als volgt toe: "Es giebt wirklich ein Ens morbi, wie es ein Ens vitae giebt; beide Mal hat eine Zelle oder ein Zellencomplex den Anspruch, so genannt zu werden" (Virchow, 1895, pp. 35-36). De cel is dus zowel kenmerk van het leven als van ziekte. In bepaalde celcomplexen treden veranderingen op, die consequenties hebben voor het grotere geheel. Het veranderde deel van het lichaam staat in een parasitaire verhouding tot het overigens gezonde lichaam (ibid., p. 23). 
Ziekten zijn, aldus Virchow, equivalent aan veranderingsprocessen van cellen: "Immer wird die Krankheit als ein veränderter Lebenszustand einer kleineren oder grōsseren Zahl von Zellen oder Zellenterritorien betrachtet werden müssen, (...)" (ibid., p. 42). Deze afwijkende celprocessen, het veranderde leven dat het object vormt van de pathologie, zijn volgens Virchow in natuurwetenschappelijke termen te beschrijven.

De levenswetenschappelijk gedefinieerde geneeskunde wees, zoals gezegd, op de kenmerkende eigenschappen van de levende natuur. De aandacht werd met name gericht op haar organisatievermogen, haar integratievermogen en haar doelgerichtheid. Men vroeg zich in dit verband af wat ziekte betekent voor het levende organisme, dat zich in stand tracht te houden temidden van de continue stroom van invloeden. De nieuwe richting in de geneeskunde was daarom niet zozeer geinteresseerd in de cellulaire veranderingsprocessen, maar in het zieke organisme als geheel. Het wezen van de ziekte verschoof dientengevolge van afwijkende processen op cellulair niveau naar inadequaat functioneren van het totale individu.

H. Ribbert (1855-1920) stelde in 1899 dat zieke cellen niet voldoende zijn om van ziekte te kunnen spreken: "Es muß erst von ihnen eine funktionelle Störung in dem Leben des übrigen Körpers abhängig werden" (Ribbert, 1899, p. 38).

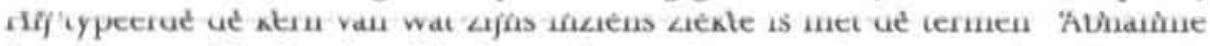
der Leistungsfähigkeit" en "funktionelle Minderwertigkeit eines oder aller Teile des Körpers" (ibid.)

In de editie uit 1908 van het Handbuch der allgemeine Pathologie, uitgegeven door F. Marchand (1846-1928) en L. (von) Krehl (1861-1937), wiens opvattingen in het volgende hoofdstuk nader worden besproken, werd eveneens erkend dat de bestudering van de pathologische verschijnselen op celniveau een der belangrijkste fundamenten vormt van de pathologie. Maar de tweede pijler van de cellulaire pathologie, de veronderstelling dat de cellen een zekere autonomie bezitten in het ziekteproces, werd niet zonder meer overgenomen. "Je mehr die Erkenntnis der feineren biologisch-pathologischen Vorgänge sich vertieft", aldus Krehl en Marchand, "desto deutlicher tritt die Einheitlichkeit des Organismus auch in seinen pathologischen Erscheinungen hervor. In der Krankheit ist nicht das hauptsächlich geschädigte Organ allein beteiligt, sondern der ganze Organismus ist mehr oder weniger in Mitleidenschaft gezogen, (...)" (Krehl \& Marchand, 1908, geciteerd in Puff, 1950, p. 12). Bij ziekte zijn dus niet alleen de celprocessen verstoord: het organisme is als geheel geraakt en het reageert daarop ook als een georganiseerd geheel.

De Poolse arts en theoreticus W. Bieganski (1857-1917) drukte zich in soortgelijke termen uit. Ook hij betrekt met nadruk het gehele organisme in zijn opvatting van ziekte. Bij zijn exploratie van het concept ziekte constateert hij allereerst 
dat de kern ervan niet uitsluitend is gelegen in functieveranderingen (Bieganski, 1909. p. 55). Vervolgens stelde hij dat het wezen van ziekte evenmin alleen in anatomisch-pathologische veranderingen moet worden gezocht (ibid., p. 58). De bacteriologische opvatting van ziekte achtte hij ook niet bevredigend. Ziekte moest zijns inziens niet uitsluitend als een functiestoornis worden opgevat, die het onmiddellijk gevolg is van een pathogene prikkel (ibid., p. 60). Bieganski gaf vervolgens zijn eigen definitie van ziekte. "Wir können schliesslich auf Grund obgenannter Erörterungen die Krankheit folgendermassen definieren: eine Reihe miteinander verbundener, teils ausschliesslich funktioneller, teils gleichzeitig funktioneller und organischer Veränderungen des lebenden Organismus, die entweder unmittelbar oder mittelbar durch Einwirkung von Reizen, für welche der Organismus nicht angepasst war, hervorgerufen werden" (ibid., p. 68). Het organisme verzet zich tegen ziekte, zo stelde hij, het reageert op de oorspronkelijke verstoring door een zekere mate van zelfregulering. Functie en vorm werken op elkaar in door een bepaalde afstemming van het organisme op de verstoring. Daardoor is ziekte nooit te begrijpen als hét gevolg van één oorzaak. Ziekte beschouwde Bieganski als een bijzonder episode in het leven, waarop door het individu op grond van zijn eigenschappen een eigen stempel wordt gedrukt. In de verschillende vormen van levenswetenschappelijke pathologie die in de eerste decennia van de twintigste eeuw opgeld doen, worden enerzijds ziekte als verminderd en inadequaat functioneren en anderzijds gezondheid als adequate reactie van het organisme op de voortdurend wisselende levensomstandigheden, tegenover elkaar geplaatst. Het leven werd op deze wijze gezien als een continu accomodatie- en assimilatieproces, waarin het individu is blootgesteld aan vele soorten van invloeden. Het reageert hierop al naar gelang de eigen aanleg en het eigen functiepatroon. Loopt er in de regulatie-mechanismen waarmee het organisme zich in stand houdt iets mis, wordt het vitale evenwicht verstoord, dan is er sprake van ziekte (vgl. Lubarsch, 1917, p. 1378).

Vanuit het standpunt van de pathologie worden, ten tijde van de levenswetenschappelijke geneeskunde, individuele verschillen belangrijker. Deze tendens tekent zich al af bij het energetisme. Individuele organisatie en structuur zijn volgens deze stroming bepalend voor het effect van uitwendige prikkels. Aanleg en milieu beïnvloeden de stabiliteit van het functioneren van het organisme. Aanpassingsvermogen en resistentie verschillen verder per individu. Ribbert attendeerde er op dat de arts bij de vraag naar het ontstaan van ziekten, van functionele stoornissen, rekening moet houden met erfelijke kenmerken en andere met de constitutie verbonden factoren (Ribbert, 1917, p. 1612). In 1932 werd het vanzelfsprekend geacht dat elk ziekteverloop mede afhangt van de individuele constitutie (vgl. o.a. Siebeck, 1932, p. 1263). 
Celprocessen bleven gelden als de basis van het menselijke lichamelijke functioneren. Maar ze worden in de levenswetenschappelijke periode relevant geacht voor de pathologie, omdat ze de belangrijkste organisatievorm van de levende natuur vormen. De Leidse hoogleraar N.Ph. Tendeloo (1864-1945), stelde dat de cellulaire pathologie niet heeft afgedaan, maar wel beperkt is. Hij schreef: "Maar de cellulaire pathologie kan ons niet ten volle bevredigen. Want de cel of celgroep kan niet meer zijn dan de drager van pathologischen aanleg, het aangrijpingspunt voor ziekmakende invloeden, de zetel van gestoorde en ongestoorde verrichting. En de geneeskundige verlangt antwoord op deze vragen: waardoor $\mathrm{en}$ hoe ontstaat ziekte? Voor de beantwoording dezer vragen is het niet voldoende, de veranderingen van cellen en weefsels nauwkeurig te kennen, wij moeten weten door welke constellatie van factoren die veranderingen ontstaan (constellatiepathologie). (...) Deze constellatiepathologie sluit de cellulaire pathologie als onderdeel in zich" (Tendeloo, 1922, p. 20).

Ziekte werd in toenemende mate gedefinieerd vanuit het perspectief van het organisme als een biologische eenheid. Het werd beschouwd als een verstoring van het individuele incasseringsvermogen, het werd gekenschetst als "Leistungsverlust", als een inbreuk op het individuele geheel. Dat betekent dat $e r$, in de ogen van de aanhangers van een levenswetenschappelijke geneeskunde, een bepaald spectrum van verrichtingen bestaat die nog onder de noemer gezond vallen. Van ziekte kan men pas spreken als de norm is overschreden (vgl. Brugsch, 1918, p. 453). Ziekte wordt opgevat als de levensverschijnselen aan gene zijde van de aanpassingsmogelijkheden van het organisme. Bij genezing keert het leven weer binnen dit kader terug, waarbij niet per se, of eigelijk per se niet, de oorspronkelijke toestand behoeft te zijn teruggekeerd (vgl. Gruber, 1924. p. 1316). De ervaring van de doorgemaakte ziekte heeft zijn neerslag in de vorm en in de wijze van functioneren van het individu. Mettertijd werd het functionele aspect steeds belangrijker, ziekte werd door G. von Bergmann (1878-1955) omschreven als functioneel lijden (vgl. Von Bergmann, 1932).

Wanneer het individuele functioneren als "geheel" als criterium wordt genomen, heeft dit tot gevolg dat het onmogelijk is een uniforme maatstaf te vinden voor het correcte gebruik van de term "ziek". Leven, gezond zijn maar ook ziek zijn, is in de levenswetenschappelijke visie een multi-dimensionaal gebeuren, dat niet kan worden opgedeeld in een aantal functies. Toch probeert men door ziekte te definiëren als disfunctie een inhoudelijk criterium te verschaffen, dat richting kan geven aan de medische praktijk. Kenmerkend aan ziekte is, volgens deze opvatting, dat het een bedreiging vormt voor het organisme. Ziekte betekent een overschrijding van individuele incasseringsvermogen en is daardoor gevaarlijk. L. Aschoff (1866-1942) beschreef ziekte als: "(...) jede Störung im 
Ablauf der Lebensvorgänge, durch welche der Organismus in seiner biologischen Existenz gefährdet wird, d.h. den gegebenen Lebensbedingungen nicht mehr angepaßt erscheint" (Aschoff, 1925, p. 17).

Op grond van deze bepaling van ziekte werd de gelijkstelling tussen normaal en gezond bekritiseerd. Ongebruikelijk functioneren hoeft immers niet als "ziek" gekenschetst te worden als de aanpassing aan het gegeven milieu probleemloos verloopt. Pas als het individuele organisme er niet in slaagt om zich adequaat aan te passen, dan zijn lijden, ziekte of dood het gevolg.

Op grond van een dergelijke bepaling van ziekte waren onderzoek naar zowel de bouw, de vorm, als naar het functioneren, de organisatie, van het menselijk organisme relevant binnen de geneeskunde. De individualiteit van het organisme, die voortvloeit uit de erfelijke eigenschappen gecombineerd met de kenmerken die de neerslag vormen van het vroegere functioneren, behoorde daarbij niet uit het oog verloren te worden. Vorm en functie bepalen elkaar en beide spelen bij ziekte een rol.

Om aan al deze aspecten van ziekte recht te doen, werd tevens een heroriêntering op de aard van het klinisch oordeel nodig geacht. Prognostiek, diagnostiek en therapie waren tijdens de levenswetenschappelijke periode dan ook geliefde thema's in de medische literatuur.

Terwijl in de natuurwetenschappelijk georiënteerde geneeskunde objectiviteit en universele wetmatigheden het grootste goed lijken, werd in de eerste decennia van de twintigste eeuw duidelijk dat er ook andere eisen aan de geneeskunde kunnen worden gesteld. Wetenschappelijke status en rationaliteit waren niet langer de enige maatstaven waar men zich bij de reflectie op de geneeskunde om bekommert. De kwaliteitsloze natuurwetenschap alleen is vanuit het perspectief van de arts te abstract. Een dergelijke vorm van wetenschap is niet toegesneden op een juist begrip van het disfunctioneren van het individuele organisme. In de mechanistische interpretatie van ziekte kan ziekte niet in haar volle breedte te voorschijn treden. Het ziektebegrip dat behoort bij een natuurwetenschappelijk gedefinieerde geneeskunde werd daarom ontoereikend geacht.

In tegenstelling hiermee wilde men in de levenswetenschappelijke conceptie van geneeskunde wel recht doen aan de eigen aard van de levende natuur, met name aan haar vermogen tot organisatie en integratie alsmede aan haar doelgerichtheid. Dergelijke bespiegelingen hadden consequenties ten aanzien van het ziektebegrip. Ziekte werd vanuit deze optiek opgevat als een vorm van individueel disfunctioneren In de volgende paragraaf zal worden aangegeven hoe binnen de geneeskunde in deze periode ook met betrekking tot het klinisch oordeel afstand werd genomen van de natuurwetenschappelijke oriëntatie. 


\subsection{Causaliteit en finaliteit. Het klinisch oordeel op twee sporen}

Sinds de geneeskunde zichzelf beschouwde als een der biologische wetenschappen, vonden discussies over de aard en de methoden van de biologie hun afschaduwing in de reflectie op de geneeskunde. De definitie van de geneeskunde als levenswetenschap bracht een heroriëntering ten aanzien van haar grondprincipes met zich mee. Het resultaat hiervan was niet alleen een herformulering van het ziektebegrip, het had ook zijn weerslag op de visie op het klinisch oordeel. Ter voorbereiding hierop zal eerst de discussie over de wetenschappelijke verklaringswijze binnen de geneeskunde worden besproken. Vervolgens wordt er op het klinisch oordeel zelf en op de arts-patiënt relatie ingegaan.

Zoals in de vorige paragrafen is aangegeven, verloor rond de eeuwwisseling het mechanicisme in biologische kringen terrein. Vitalistische en andere organicistische denkbeelden raakten steeds meer in zwang. De beperktheid van het mechanicisme werd aan de kaak gesteld. Men bepleitte in dit verband met name een aanvulling van de natuurwetenschappelijke verklaringswijze met een teleologisch supplement. De argumenten voor deze verruiming van de wetenschappelijke benadering waren tweeërlei. Aan de ene kant achtte men de gangbare causaal-analytische methoden van de natuurwetenschap gebrekkig, omdat ze geen recht doen aan de specifieke eigenschappen van de levende natuur. De argumentatie berustte dan voornamelijk op de veranderde wijsgerige inzichten omtrent het object van de geneeskunde. Aan de andere kant werd de praktijk van het klinisch oordeel aangevoerd om de geldigheid van de natuurwetenschappelijke visie daarop te bestrijden. Achtereenvolgens zullen beide argumentatiepatronen worden besproken.

In de levenswetenschappen raakte men er in toenemende mate van overtuigd dat als men de levende en de dode natuur in het wetenschappelijk onderzoek over één kam scheert, bepaalde relevante aspecten van de levende natuur uit het oog worden verloren. Binnen de levende natuur is niet alles te duiden in termen van kracht en materie, zo meende men. Het standpunt dat de natuurwetenschappelijke benaderingswijze slechts een methodologische reductie vormt, dat wil zeggen dat de natuurwetenschap er niet vanuit gaat dat de levende natuur in werkelijkheid identiek is aan de dode natuur maar slechts voorschrijft dat beide op identieke wijze onderzocht moeten worden, loste de bezwaren niet op. Juist dat surplus werd voor de beoefenaar van de levenswetenschappen van belang geacht en daarom mocht het niet verwaarloosd worden. Begrip van de levende natuur vereist een bredere benadering dan van de levenloze materie, omdat in de gangbare causaal-analytische verklaringwijze van de laatste essentiële aspecten over het hoofd worden gezien.

De aanhangers van een levenswetenschappelijke geneeskunde beklemtoonden de harmonie, de orde en de regelmaat in de levende natuur. Burger schreef: 
"Alle organen, alle cellen werken in harmonisch, d.i. doelmatig verband samen ten dienste van het geheel" (Burger, 1928, pp. 7-8). Deze harmonie valt buiten het kader van de natuurwetenschap, de fysische causaliteit is juist hiervoor doof (vgl. ibid., p.10). Men wenste niet langer genoegen te nemen met de methodologische begrenzingen van de wetenschap, die enkele decennia eerder door de natuurwetenschappelijke geneeskunde waren verdedigd. Men stelde zich open voor alternatieve concepten van causaliteit en nam het op zich om andere typen van oorzakelijkheid te onderzoeken.

Binnen het natuurwetenschappelijk wetenschapsconcept was geen plaats voor beschouwingen over de harmonie in de levende natuur. De beoefenaar van de natuurwetenschap vraagt naar oorzaken. Hij schetst hoogstens hoe in de levende natuur overal wetten en oorzaken werkzaam zijn als basis van de harmonie (vgl. Donders, 1972 (1848)). Speculaties, bijvoorbeeld over het doel van de harmonie werden niet zinvol en niet wetenschappelijk geacht. Du Bois-Reymond had, zoals ook in het vorige hoofdstuk is aangegeven, in de hoogtijdagen van de natuurwetenschappelijke geneeskunde de harmonieuze ordening der natuur zelfs tot een der zeven wereldraadsels verklaard (vgl. Du Bois-Reymond, 1891 (1872); $1891(1880)$ ). Het was volgens de natuurwetenschappelijke geneeskundigen principieel onmogelijk om dergelijke raadsels op wetenschappelijke basis verder te doorgronden.

Volgens de aanhangers van de levenswetenschappelijke geneeskunde mocht men daarentegen in de wetenschappelijke bestudering van de levende natuur niet buiten beschouwing laten dat levende organismen een eigen samenhang vertonen en dat ze een zekere mate van organisatie bezitten. Essentieel aan organismen is dat ze een geheel vormen; zij zijn niet volledig te ontleden in onderscheiden functies of delen. Dit impliceert dat het principe van de analyseerbaarheid niet zonder meer van toepassing kan zijn ten aanzien van de levende natuur. De harmonieuze organisatie in de levende natuur kan niet straffeloos genegeerd worden, omdat ze het functioneren van de organismen op alle niveaus bepaalt. Tezelfdertijd werd in de biologische wetenschappen het alleenrecht van het natuurwetenschappelijk causaliteitsbegrip in twijfel getrokken. Men greep terug op de aristotelische onderscheiding in verschillende vormen van oorzakelijkheid en bekritiseerde de beperkte visie van de moderne natuurwetenschap. Bij de bestudering van fenomenen als evolutie en groei lijken factoren een rol te spelen, die niet passen binnen het natuurwetenschappelijk verklaringskader, zo meende men. Deze fenomenen zouden wel kunnen worden verklaard als het te bereiken doel bij de beschouwing zou mogen worden betrokken. Men concludeerde dat in de levenswetenschappen de finale of teleologische beschouwingswijze niet langer van de hand gewezen moest worden. Het wetenschappelijk verklaringsmodel diende te worden verbreed, zodat ook dergelijke typen oorzaken erkenning vinden (vgl. o.a. Van Balen, 1933, pp. 82 e.v.). 
Intussen werd binnen de geneeskunde de causale benaderingswijze als zodanig niet verworpen. De geldigheid van de natuurwetenschappelijke beschouwingswijze werd niet bestreden, maar wel ingeperkt. De reikwijdte van de natuurwetenschappelijke verklaringswijze werd gerelativeerd. Binnen de levenswetenschappen waren causale analyses niet ongeldig, zo werd gesteld, maar ze zijn wel begrensd. Men trachtte daarom het causaal-analytisch denken aan te vullen met beschouwingen die wel recht doen aan de eigen aard van de levende natuur. Om inzicht te krijgen in het functioneren van het levende organisme diende men zich te realiseren dat dit wordt bepaald door het streven naar zelfhandhaving. Het organisme werd opgevat als een zichzelf regulerend en organiserend totaal, dat een systeem van onderling afhankelijke variabelen vormt, waarin vorm en functie niet van elkaar te scheiden zijn. Dat het organisme onmiskenbaar meer is dan de som der levensverrichtingen blijkt, aldus de levenswetenschappelijke geneeskunde, onder andere bij de verklaring van herstellingsverschijnselen en van het natuurlijk regeneratievermogen van het organisme. Als geintegreerd geheel is het organisme niet volledig toegankelijk voor de analyserende natuurwetenschap. Alleen een teleologische benadering die het complement vormt van de causale analyse kan hieraan recht doen, zo meende men binnen de geneeskunde.

De mogelijke verenigbaarheid van enerzijds principes die specifiek zijn voor de levende natuur met anderzijds natuurwetenschappelijke methoden, was een kwestie die de gemoederen in medisch wetenschappelijke kringen bezighield. Door een combinatie van natuurwetenschap en teleologie hoopte men tot een adequaat wetenschappelijk verklaringsmodel te komen. Bieganski baseerde zich, in zijn argumentatie ten gunste van de teleologie, op een nadere aanduiding van de eigen aard van organismen (vgl. Bieganski, 1909, pp. 117 e.v.). De levende natuur verschilt wezenlijk van de dode natuur en daarom is de causale verklaringswijze zijns inziens ontoereikend. In de levende natuur zijn deel en geheel op een specifieke wijze vervlochten. Deze relatie komt niet overeen met de wijze waarop in een machine onderdelen afhankelijk zijn van het geheel, aldus Bieganski. Tussen machines en organismen kan men wel analogieên opstellen, beide zijn doelmatig, maar ze verschillen op een wezenlijk punt. Machines werken volgens een door de technicus aangebracht plan, het doel komt van buiten af. Levende organismen organiseren zichzelf daarentegen volgens een in de kiem aanwezig plan. Het levende organisme noemde Bieganski een gesloten systeem. Dit gesloten systeem is, zo schreef hij. " (...) zusammengesetzt aus Teilen, von deren Existenz und Tätigkeit die Existenz und die Funktionierung des Systems abhängig ist und die wiederum ihrerseits in ihrer Form. Existenz und Funktion von dem ganzen System und dessen allgemeiner Tätigkeit abhängen. Wir haben es hier also mit einer gewissen gegenseitigen Abhängigkeit der Teile vom Ganzen und des Ganzen von den Teilen zu tun; diese Abhängigkeit nennen wir, nach Analogie mit den zweckmăssigen Produkten menschlicher Arbeit, ebenfalls zweckmāssig" (ibid., p. 119). 
De complexiteit van de biologische verschijnselen, die voortspruit uit de doelmatige organisatie van het levende organisme als gesloten systeem, noopte volgens Bieganski tot een teleologische beschouwingswijze. Deze constatering was zijns inziens niet alleen op theoretisch niveau relevant, hij heeft ook implicaties voor het klinisch oordeel. Overal waar de verrichtingen van het organisme als geheel worden onderzocht, met name in die gevallen waarin regulatieprocessen een rol spelen, treedt zijns inziens de noodzaak van een teleologisch gezichtspunt aan de dag. Hij vatte zijn overwegingen als volgt samen: "Kurz bei der Untersuchung der Regulationen tritt das Bedürfnis der Zweckbetrachtung zutage, welche hier die kausale Betrachtung vervollständigen muss und ohne welche das Ganze der biologischen Erscheinungen nicht genau begriffen werden kŏnnte" (ibid., pp.123-124). Biologische verschijnselen zijn zo met elkaar verstrengeld dat de kennis van causale relaties tussen bepaalde geisoleerde momentopnames niet voldoet. De combinaties van determinanten komen voort uit een bijzonder type noodzakelijkheid, ze zijn noodzakelijk vanuit de organisatie van het organisme. Begrip van de betekenis van deze verschijnselen ontstaat pas in een integrale benadering van het organisme, van zijn bestaanswijzen en zijn behoeften. Dat betekent niet dat de causale verklaringswijze werd verworpen, maar dat ze (slechts) een onderdeel vormt van het gewenste resultaat. De eerdere strijd tegen de teleologische optiek in de biologische wetenschappen bestempelde Bieganski als doctrinair. De aanname van een doelgerichtheid was zijns inziens zeker niet onwetenschappelijk. Als de teleologie wordt geaccepteerd, impliceert dat geenszins dat wetenschappelijk onderzoek is uitgesloten. De methoden verschillen volgens Bieganski zelfs weinig van de causale benadering. $\mathrm{Ze}$ verschaffen alleen de onmisbare extra dimensie van de doelgerichtheid.

De teleologische beschouwingswijze is onmisbaar bij onderzoek binnen de fysiologie en in nog sterkere mate bij de pathologie en de praktische geneeskunde. Als men in het klinisch oordeel recht wil doen aan de individuele eigenschappen van het organisme, is het volstrekt onvoldoende als men alleen ketens van causaal verbonden veranderingen traceert. Als men dit niet inziet, kan het kwalijke gevolgen hebben. Juist in een concreet geval moet men de betekenis van de verschillende afwijkingen voor het organisme als geheel zien op te sporen. Deze afwijkingen zijn niet alle even relevant voor het bestaan van het organisme. Door middel van een teleologische beschouwingswijze kan men de betekenis van de verschillende pathologische veranderingen voor het organisme als geheel beoordelen (vgl. ibid., pp. 124 e.v.). Vooral bij het uitstippelen van een therapie is het perspectief van de doelgerichtheid onmisbaar, aldus Bieganski, omdat men daar in het oog moet houden of bepaalde processen schadelijk zijn voor het zieke organisme of niet (vgl. ibid., p. 127).

Bieganski baseerde zich in zijn betoog ten gunste van de teleologische benadering voornamelijk op overwegingen die het object van de wetenschap betreffen. 
Zijn pleidooi voor de teleologie vormt daarom een voorbeeld van de hierboven geschetste eerste redeneerwijze. Hij kiest op wijsgerige gronden voor de teleologie.

De combinatie van natuurwetenschap met teleologie werd, evenals in de discussie over het ziektebegrip, ook bepleit op grond van overwegingen die waren ontleend aan de ervaringen in de onderzoekspraktijk. Daarbij werd er op gewezen dat voor een wetenschap, die het functioneren van levende organismen wenst te begrijpen als een resultante van uitwendige invloeden, individuele aanleg en milieu, de natuurwetenschappelijke methoden te weinig opleveren.

Een goed voorbeeld van een dergelijke redenering wordt geleverd door de Berlijnse hoogleraar in de chirurgie A. Bier (1861-1949). Hij constateerde: "Aber auch unsere jetzigen angeblich so hoch gestiegenen naturwissenschaftlichen Kenntnisse haben doch in Wirklichkeit für die Erklärung und das Verständnis des Lebens so gut wie nichts geleistet. Deshalb ist auch die heutige mechanistische Betrachtungsweise mindestens sehr unvollkommen und bedarf dringend der Ergănzung durch eine andere, um zu brauchbaren Ergebnisse zu gelangen" (Bier, 1922, p. 845). Ook Bier verwierp de natuurwetenschappelijke onderzoekswijze niet. Integendeel, hij was diep overtuigd van haar belang en wil haar zo ver mogelijk doorvoeren. Maar toch blijft er dan bij levensverschijnselen een onverklaard restant over, meende hij. Ten aanzien van dergelijke verschijnselen is het raadzaam om zich, in de praktische geneeskunde, te bedienen van een andere verklaringsmethode, de teleologische verklaring. Bier verklaarde: "Man muss sich aber bewusst sein, dass, wenigstens heute noch, immer bei Lebensvorgängen ein unerklärter Rest bleibt, den man mit einer anderen Betrachtungsweise besser begreift, wenn man für die praktische Medizin wichtige Schlüsse ziehen will. Diese Betrachtungsweise, die ich der mechanistischen an Wert zur Seite stelle, ist die vielverketzerte teleologische (...)" (ibid., p. 846).

Bier stelde uitdrukkelijk dat hij met deze herwaardering van de teleologie niets mystieks op het oog had. Hij wenste ook geenszins als vitalist beschouwd te worden. Hij wilde alleen de doelmatigheid in de levende natuur en de gerichtheid op de instandhouding van het individu en van de soort als ervaringsfeit in de geneeskunde inbrengen. Een causale en een teleologische benaderingswijze sluiten elkaar niet uit maar vullen elkaar aan bij de bestudering van de levende natuur, volgens Bier. "Ganz im Gegenteil, sie unterstützen sich gegenseitig und geben die Mōglichkeit einen Gegenstand von zwei Seiten zu betrachten, die sich als die wirksamsten und besten in der Forschung bewährt haben und die wenigstens heute noch, gleichberechtigt nebeneinander stehen" (ibid., p. 849). Volgens de levenswetenschappelijk georiënteerde medici aan het begin van de twintigste eeuw was in de praktijk een teleologische beschouwingswijze onmisbaar. In het klinisch oordeel treedt het belang van de teleologie duidelijk aan 
de dag: "Het is de kunst van den geneesheer, in elk bijzonder geval het ingewikkeld samenstel der ziekteverschijnselen te ontrafelen en te midden van vele vijanden waardevolle bondgenoten te ontdekken. Een klaar inzicht in het, bij gezondheid en ziekte, naar een doel gericht zijn der levensverschijnselen behoedt hem voor een averechtsche symptomatische behandeling" (Burger, 1928, p. 11). Zowel in het medisch wetenschappelijk onderzoek als in de klinische praktijk dient volgens deze opvatting de geneeskundige de toestand van het organisme te onderzoeken door deze te ontleden in causale ketens van fysisch-chemische processen. Vervolgens behoort hij de resultaten van het zuiver causaal onderzoek te waarderen op grond van hun betekenis voor de instandhouding van het individu. Dat betekent dat de arts een dubbele positie moet innemen, zoals Aschoff beschreef (vgl. Aschoff, 1925, p. 15). De arts denkt enerzijds in fysisch-chemische grootheden oftewel causaal en anderzijds "organismisch" oftewel teleologisch .

Men beschouwde in het begin van de twintigste eeuw het klinisch oordeel niet slechts als een op algemene wetmatigheden gefundeerde verklaring van een bepaalde stand van zaken. De individuele inbreng van de patiënt, het specifieke karakter van diens functioneren, werd relevant geacht voor de geneeskunde. De natuurwetenschap predikte de gelijkheid van alle mensen in geval van ziekte. In de levenswetenschappelijke periode werd daarentegen de nadruk gelegd op de eigen aard van het individu. De patiênt werd niet gezien als een element uit een mogelijk oneindige verzameling van identieke elementen, die alle op dezelfde wijze ondergeschikt zijn aan de natuurwetten. In de levenswetenschappelijke conceptie van het klinisch oordeel lette men juist op de betekenis van het eigen functioneren voor het ene concrete individu. Dit functioneren is niet volstrekt willekeurig. Het verloopt volgens een bepaald stramien, dat de neerslag vormt van de aanleg en de omstandigheden die specifiek zijn voor het individu. De individuele verwerking van de causaal bepaalde fysische en chemische processen staat centraal. Daartoe behoeft men de teleologische, doelmatige, en individualiserende benadering.

Aangezien het individuele functioneren geacht wordt een eigen karakter te vertonen, werd de anamnese zeer belangrijk. Langs deze weg verkrijgt men kennis van de voorgeschiedenis en de levensomstandigheden van de patiënt. Aan de hand van deze gegevens en op grond van het uitgangspunt dat het organisme zichzelf poogt te handhaven, trachtte men de betekenis van de huidige vormen van functioneren te doorgronden. Op deze manier verwachtte men recht te kunnen doen aan de eigen aard van het individu en aan zijn specifieke wijze van functioneren, terwijl de geneeskunde haar claim op rationaliteit en wetenschappelijkheid niet opgaf. Men verwierp immers de natuurwetenschappelijke methoden niet maar plaatste ze in een breder verband. 
De combinatie van natuurwetenschap en teleologie leverde een sterke inperking op van het methodisch materialisme. Toch bleef men vasthouden aan het uitgangspunt dat een natuurwetenschappelijke bestudering van levensverschijnselen mogelijk is. Terwijl enerzijds werd gesteld dat analyserende methoden per definitie tekortschieten, werd anderzijds de veronderstelling dat deze verschijnselen als materiële processen moeten en kunnen worden onderzocht niet losgelaten. De teleologie werd te hulp geroepen om het organisme als organisme tot zijn recht te laten komen, terwijl men tegelijk van mening bleef dat de natuurwetenschap toch zinnige resultaten oplevert. Ondanks de verschillen tussen de dode en de levende natuur achtte men op beide terreinen, omwille van het wetenschappelijk gehalte, de causaal-analytische benadering van de natuurwetenschap toelaatbaar en zelfs gewenst. Tezelfdertijd vroeg men echter in de levenswetenschappen, waartoe ook de geneeskunde werd gerekend, om erkenning voor een extra dimensie van de levende natuur. De materiële processen in de levende natuur staan immers niet op zichzelf, zo luidde de motivering. Bij organismen staan ze uiteindelijk in dienst van het zelfbehoud. Daarom zijn ze nooit ten volle analyseerbaar in fysisch-chemische termen. Om dit aspect toch toegankelijk en begrijpelijk te maken voor de geneeskunde omarmde men het teleologische denken.

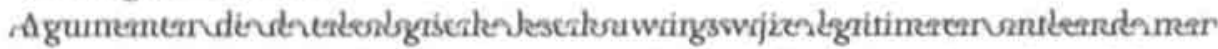
ook wel aan haar waarde voor het wetenschappelijk onderzoek op het vlak van de geneeskunde. De teleologische benadering had vruchtbare onderzoeksterreinen geopend, waarbinnen men overigens weer op natuurwetenschappelijke leest geschoeid onderzoek verrichtte. $\mathrm{Zij}$ verschafte interessante hypothesen die men vervolgens op natuurwetenschappelijke wijze, analyserend, toetste. Ondanks de uitvoerige pleidooien voor de teleologie, moeten worden geconstateerd dat op het niveau van het onderzoek het belang van de teleologische optiek niet veel verder blijkt te reiken dan de heuristische waarde. De teleologische of finale beschouwingswijze bezat geen eigen onderscheiden methode. Evenmin pretendeerde zij een eigen vorm van wetenschappelijkheid te kennen die zich op een of andere manier kon meten met de natuurwetenschap. Men blijkt de teleologie naar believen te hebben kunnen aanvaarden of afzweren, zonder dat het wetenschappelijk gehalte van het onderzoek er onder leed (vgl. Von Bergmann, 1932. p. 412),

In de reflectie op de arts-patiënt relatie, stelde men vast dat voor de diagnose, de prognose en de therapie, de betekenis van de disfunctie voor de patiënt van essentieel belang is. Binnen de geneeskunde moet men zich daarvan rekenschap geven en de anonimiteit van de natuurwetenschappelijke geneeskunde ontstijgen. De natuurwetenschap streeft waardevrije en objectieve kennis na, de onderzoeksobjecten worden over één kam geschoren. In de levenswetenschappelijke periode zocht men binnen de geneeskunde juist naar een geschikte 
onderzoeksmethode die recht doet aan de individualiteit. De geneeskunde kon zich dan ook niet langer spiegelen aan de natuurwetenschap, als het de relatie tussen onderzoeker en onderzochte, tussen arts en patiënt, betreft (vgl. o.a. Koch, 1917. p. 53: Honigmann, 1913, pp. 45 e.v.; Burger, 1928, p. 14).

De argumenten tegen de natuurwetenschappelijke invulling van de arts-patiênt relatie laten zich in twee categorieên indelen. Enerzijds werd de natuurwetenschappelijke definitie van geneeskunde verworpen omdat de geneeskunde geen objectieve natuurwetenschap kan zijn. De arts kan en mag niet abstraheren van het lijden van de patiënt. Daarom moet de patiênt door de arts als individu, of als persoon, bekeken worden. Deze positie werd onder andere verdedigd door Schweninger. De praktische geneeskunde verschilt zijns inziens qualitate qua van de wetenschap, ook van de biologisch georiënteerde wetenschap. Wetenschap is koel en gevoelloos, maar geneeskunde vereist een morele betrokkenheid. Schweninger verbond hieraan de conclusie dat binnen de geneeskunde elke wetenschappelijke pretentie radicaal moet worden afgewezen.

De reden tot verwerping van de natuurwetenschappelijke definitie van de geneeskunde kon ook van internwetenschappelijke aard zijn. De wetenschappelijke status van de geneeskunde werd dan niet opgegeven, maar men vroeg aandacht gevraagd voor het specifieke karakter van de geneeskunde als wetenschap. Dit type argumentatie treft men aan bij Honigmann en Koch. Zij hebben er met klem op gewezen dat de standaarden van de natuurwetenschap in het geval van de geneeskunde te beperkt zijn. Ziekte is een individueel gegeven, dat bij niemand gelijk is. Daarom dient de persoonlijkheid, de identiteit of de individualiteit in het klinisch oordeel, in de arts-patiënt relatie, betrokken te worden. Een goede arts weet de resultaten van de natuurwetenschap en de biologie toe te passen, daarin bestaat zijn deskundigheid. De arts moet echter wel arts blijven en zich niet laten verleiden tot de positie van de gewone wetenschapsbeoefenaar. Honigmann formuleerde zijn visie als volgt: "So kann er nie stehen bleiben, die beiden Hauptmomente seiner Erkenntnis: auf der einen Seite die durch die Empirie brauchbar gemachte experimentelle Pathologie, auf der anderen Seite die durch die Wissenschaftlichkeit der Beobachtung geläuterte Empirie, werden sich gegenseitig die Wagschale halten und beide zusammen werden den Pulsschlag seiner künstlerischen Intuition regulieren. Wer auf dem festen Kulturboden der uralten, ewig jungen ärztlichen Kunst steht und mit sicherer Hand diese Schätze von beiden Seiten zu schöpfen weiss, der ist der wahrhaft moderne Arzt."(Honigmann, 1913, p. 54). De zielloze mechanismen van de natuurwetenschappen moeten worden gerelativeerd, ze vormen een te eenzijdig uitgangspunt voor de geneeskunde, aldus Koch (vgl. Koch, 1923, p. VIII).

In de periode van de levenswetenschappelijk georiënteerde geneeskunde was men van mening dat de natuurwetenschap als wetenschapsideaal tekortschiet. 
De geneeskunde kan het, op grond van overwegingen die zowel zijn ontleend aan de fundamentele inzichten rond haar object als aan haar praktijk, niet stellen zonder teleologische beschouwingen of zelfs een geesteswetenschappelijk complement. Het is, volgens Burger, dringend geboden om in de geneeskunde aan de zieke mens, als subject, als persoon, als psyche, alle recht te doen wedervaren (vgl. Burger, 1928, p. 14). Dit heeft men willen realiseren door de natuurwetenschappelijke analyses in een teleologisch kader te plaatsen.

De combinatie van causaliteit en teleologie werd steeds meer als onbevredigend ervaren. In de loop van de periode die wij hier bespreken verkregen eerst de individualiteit en vervolgens de persoonlijkheid van de patiënt een steeds belangrijker positie in het klinisch oordeel. De beleving van het disfunctioneren door de patiênt, de betekenis ervan voor zijn persoon, werd in toenemende mate relevant geacht voor een adequate uitoefening van de geneeskunde. Ziekte wordt immers niet alleen bepaald door de individuele somatische kenmerken, maar ook door de psychische. "Elke persoonlijkheid, ook de zieke, wordt beoordeeld naar haar gedrag en haar uiterlijk, dus naar haar verrichtingen en haar vorm. Tot de verrichtingen behooren de physiologische en de psychologische, tot den vorm de anatomische bouw, het resultaat van centrifugale impulsen, dus ook van verrichtingen" (Wiersma, 1932, pp. 2594-2595). De optelsom van natuurwetenschap en teleologie voldeed minder naarmate de mens meer als psycho-fysieke eenheid werd opgevat. Het streven naar eenheidsopvattingen, die de verschillende aspecten van het menszijn integreren, strekte zich uit tot de geneeskundige verklaringsmethoden. De stroming die in het volgende hoofdstuk wordt beschreven, vormt een concretisering van deze wens. Ter afsluiting van dit hoofdstuk wordt echter eerst aandacht besteed aan de ideeën over de geneeskunde van de neuroloog Winkler en vervolgens aan die van de anatoom Barge.

\subsection{CornelisWinkler (1855-1941)}

Cornelis Winkler werd geboren op 25 februari 1855 te Vianen, als oudste zoon in een familie van artsen. In 1873 begon hij zijn studie te Utrecht, waar onder anderen Donders zijn leermeester was. Hoewel de geneeskunde-opleiding in deze jaren meer gestructureerd en wettelijk gereguleerd was dan in de periode van Donders' studie, was Winkler later van mening dat er sprake was van serieuze lacunes (vgl. Winkler, 1947, p. 29). Zo ontving hij geen onderwijs in de huid- en geslachtsziekten, in de psychiatrie en in de neurologie.

Winkler promoveerde in 1879 op een studie over het "virus tuberculosum". In dat zelfde jaar behaalde hij zijn artsexamen. Hij werd vervolgens aangesteld als assistent in het Gemeenteziekenhuis te Den Haag. Omdat hij niet tevreden was 
met de werkomstandigheden in dit ziekenhuis zocht hij spoedig een andere positie. In zijn Herinneringen schrijft Winkler dat Donders hem het voorstel deed om als lector in de psychiatrie naar Utrecht te komen. Hij sloeg dit aanbod om verschillende redenen af. Hij vond dat hij onvoldoende van psychiatrie afwist en vroeg zich ook af of de omgang met krankzinnigen hem wel zou bevredigen. Tenslotte voelde hij er niets voor om ter wille van de psychiatrie een serieuze studie te moeten maken van de psychologie en de filosofie (vgl. Winkler, 1947, p. 37). In 1881 keerde Winkler toch terug naar Utrechtse universiteit, waar hij poliklinisch assistent werd van S. Talma, toentertijd hoogleraar in de interne geneeskunde. In deze periode ondernam hij een laboratoriumonderzoek naar de polsbeweging der aderen.

In 1882 ontmoette Winkler op een studiereis in Wenen verschillende vooraanstaande psychiaters en neurologen. Eén van hen, J. Wagner-Jauregg (1857-1940), die later in Wenen hoogleraar psychiatrie werd, overtuigde hem ervan dat men de psychiatrie vanuit een fysiologisch en neurologisch standpunt kan onderwijzen. Sinds die tijd richtte Winkler zijn activiteiten steeds meer op de neurologie en de psychiatrie. Hij werd onbezoldigd geneesheer aan het krankzinnigengesticht te Utrecht. In 1885 volgde zijn benoeming tot lector in de psychiatrie. In 1886-1887 heeft Winkler, als expert op het gebied van de histologie van het zenuwstelsel, deelgenomen aan een expeditie naar Nederlands-Indië om onderzoek te doen naar de oorzaak van de inheemse ziekte beri-beri.

In 1893 werd Winkler aan de Rijksuniversiteit Utrecht tot hoogleraar in de psychiatrie en neurologie benoemd. Aan deze benoeming was de belofte verbonden dat er in Utrecht een psychiatrisch-neurologische kliniek zou worden gebouwd. In 1896, na meer dan twee jaar strijd over het al of niet tot stand komen van een dergelijke kliniek, besloot Winkler echter om ontslag te nemen (vgl. o.a. Winkler 1896b, pp. 12 e.v.). Korte tijd daarna werd hij benoemd tot hoogleraar in de neurologie en psychiatrie aan de Gemeentelijke Universiteit van Amsterdam. Achttien jaar later keerde hij terug naar Utrecht, aangetrokken door het aldaar opgezette nieuwe neurologische-psychiatrische instituut. Op 8 februari 1915 hield hij voor de tweede keer een intreerede als hoogleraar te Utrecht. In 1925 ging Winkler met emeritaat. Op 8 mei 1941 is hij overleden.

Aan het begin van zijn loopbaan hield Winkler zich met verschillende onderdelen van de geneeskunde bezig. Dat was ook niet verwonderlijk in een tijd waarin de specialisatie nog veel minder was voortgeschreden dan tegenwoordig. Terugblikkend op zijn loopbaan, heeft Winkler zijn activiteiten in Den Haag beschreven, waar hij nu eens als chirurg en dan weer als psychiater optrad (Winkler, 1947, pp. 33 e.v.). Vanaf 1883 specialiseerde Winkler zich op het gebied van de neurologie en de psychiatrie. Zijn interesse voor de psychiatrie betrof vooral de anatomische en fysiologische fundamenten van deze tak van geneeskunde. 
Winklers doelstelling was om inzicht te verkrijgen in de functie van het zenuwstelsel en, in dit licht, van de betekenis van de verschijnselen die zich in de kliniek voordoen. Het zwaartepunt van zijn activiteiten lag daarom op het gebied van de neurologie. Hij was werkzaam als neuro-anatoom, neuro-fysioloog, neuro-embryoloog en klinisch neuroloog (vgl. Stenvers sr., 1955, p. 640).

Winklers werk getuigt van een grote interesse in de internationale ontwikkelingen op zijn vakgebied. Hij nam persoonlijk deel aan de wetenschappelijke discussies. Hij reisde veel en onderhield contacten met buitenlandse neurologen en psychiaters. Winkler is in 1909 één der oprichters van de "Amsterdamse Neurologenvereeniging". Deze vereniging, die neurologen de gelegenheid bood om met elkaar over klinische en wetenschappelijke problemen van gedachten te wisselen, is van groot belang geweest voor de ontplooiing van de neurologie in Nederland. In dezelfde tijd werd Winkler tot vertegenwoordiger van de "Braincommission" benoemd. Deze commissie stelde zich ten doel op internationale schaal centrale instituten in te stellen die gewijd zijn aan de studie van de bouw en functies van het centrale zenuwstelsel. Tevens beoogde ze de aaneensluiting van bestaande inrichtingen voor onderzoek van het zenuwstelsel (vgl. Winkler, 1909. pp. 19 e.v.). Men hoopte op deze wijze tot een stroomlijning te komen van de organisatie en documentatie van het onderzoek en bijvoorbeeld onenigheid over nomenclatuur te vermijden. Mede op instigatie van Winkler werd in Nederland op 8 juni 1909 het Centrale Instituut voor Hersenonderzoek geopend, dat aansloot op dit streven van de "Braincommission".

Winkler heeft zich opgeworpen als een voorvechter van het belang van de psychiatrie en de neurologie in de medische opleiding. Herhaaldelijk stelde hij dat scholing in deze vakken niet alleen verplicht behoort te zijn voor de aanstaande gestichtsarts, maar ook onmisbaar is voor elke medicus. Het klinisch vermogen van de arts wordt erdoor vergroot en men krijgt inzicht in omstandigheden die zeer bepalend zijn voor het functioneren van de patiënten. Winkler streed daarom op vele fronten voor onderwijs in de psychiatrie aan alle Rijksuniversiteiten en voor de bouw van daarbij behorende psychiatrische klinieken. Hij wordt daarom wel aangemerkt als de stichter van het psychiatrisch onderwijs in Nederland (vgl. Van Valkenburg, 1955, p. 647).

Gedurende zijn lange leven is Winkler getuige geweest van een aantal verschuivingen in het geneeskundige wetenschapsconcept. Op het moment van zijn eerste intreerede, in 1883, was het aanzien van de natuurwetenschappelijke benaderingswijze tanend. Organicistische tendensen begonnen de kop op te steken. Winkler schaarde zich onder de voorstanders van een levenswetenschappelijk georiënteerde benaderingswijze. Wij zien hem dan ook positie kiezen in de discussies die de overgang van de natuurwetenschappelijke naar de levenswetenschappelijke conceptie van geneeskunde markeren. Zonder de empirische 
natuurwetenschappelijke werkwijze te willen verwerpen pleitte hij voor een organicistische optiek binnen de psychiatrie en neurologie. Later verdedigde hij zijn ideeën tegenover de psycho-analyse en de "verstehende" psychiatrie van $\mathrm{K}$. Jaspers (1883-1969) die, zoals in het volgende hoofdstuk blijkt, als inspiratiebron voor de antropologische beschouwingswijze in de geneeskunde hebben gegolden. Winkler zag weinig in een meer psychologische psychiatrie. Hij hield binnen zijn vakgebied vast aan een anatomisch-fysiologische benadering op biologische grondslag.

In zijn eerste intreerede in Utrecht, op 20 september 1893, schetste Winkler de ontwikkelingen in de geneeskunde van de laatste 100 jaar. De geschiedenis van de geneeskunde in de negentiende eeuw toont dat er in de geneeskunde onmiskenbaar sprake is van vooruitgang, aldus Winkler. "De geneeskunde heeft hare zusters, de zeer exacte natuurwetenschappen, leeren hoogachten, heeft op elk gebied van haar geborgd, maar is desniettemin meesteresse gebleven in haar eigen huis, is geen natuur- of scheikunde, geen ontleedkunde, geen ziektekundige ontleedkunde geworden, maar een zelfstandige wetenschap, die voor haar studiën, anders maar even exact als die der zusters, dezelfde achting vordert. Aan de hand van strenge studie bouwde zij hare kunst, het geneeskundig handelen op, en geheel anders dan voor honderd jaren staat thans de geneesheer aan het ziekbed" (Winkler, 1893, p. 3). In de afgelopen honderd jaar is de positie van de arts aan het ziekbed eveneens grondig gewijzigd, zo stelde hij. De arts ziet de ziekteverschijnselen niet langer als de uiting van een in het organisme gedrongen boosaardig "ens"dat moet worden verjaagd. Er is nieuwe opvatting van ziekte gegroeid, de ontologie ging voorbij (vgl. ibid., p. 4). De kloof tussen normale en zieke levensverrichtingen werd overbrugd. Dit opende de deur voor een andere handelwijze. Terwijl men een eeuw geleden nog de ziekte behandelde, wordt heden ten dage de zieke behandeld. In de loop der tijd is de geneesheer meer en meer "minister non magister naturae" geworden, aldus Winkler (ibid.). Wezenlijk voor ziekzijn is dat het een individueel karakter draagt, het is geen proces dat zich telkens volgens een identiek patroon ontrolt. Het ziekteverschijnsel heeft volgens Winkler de betekenis verkregen van: "(...) een nuttig, een noodzakelijk antwoord, dat het hoog-georganiseerde individu moet kunnen geven, als het in bizondere omstandigheden wordt geplaatst" (ibid.). Deze bijzondere omstandigheden kunnen bepaalde fysische of chemische invloeden zijn, of levende ziekteoorzaken. Wezenlijk is dat het organisme op grond van een dergelijke bedreiging zijn levensuitingen aanpast. "Het is derhalve de natuurkeus, die aan het gezonde individu, als een nuttige eigenschap voor het behoud der soort, het vermogen medegeeft, om op bepaalde oorzaken te kunnen reageeren met bepaalde uitingen - met ziekteverschijnselen" (ibid., p. 5). Elke soort heeft een bepaald scala van verschijnselen waarbinnen het reageert. Maar daarbinnen drukt de individuele geaardheid een stempel op ieder geval. "De zelfstandigheid der 
ziekteverschijnselen is derhalve innig verbonden aan de zelfstandigheid der individueele variatie", zo stelt Winkler, "Zijn de individuen ongelijk, dan is er ook geen gelijkheid te verwachten in hun levensuitingen, waartoe de ziekteverschijnselen behooren. En het behoeft nauwelijks hier herhaald te worden, wat reeds zoo dikwerf is gezegd, dat elke persoonlijkheid 'eenig in hare soort', als een unicum in de natuur verschijnt" (ibid.).

Winkler beklemtoonde in deze rede het belang van dispositie en constitutie bij het optreden van ziekte en verdedigde een op het unieke individu toegespitste benaderingswijze. Hij schetste het belang van erfelijke aanleg en persoonlijkheid voor de taakstelling van de psychiater. Verder onderschreef hij de stelling dat ziekteverschijnselen als levensuitingen moeten worden gezien en dat ze als zodanig worden bepaald door twee factoren: de organisatie van het individu en de omstandigheden waarin het individu leeft (ibid., p. 22 e.v.). Psychiaters moeten, volgens Winkler, stambomen bestuderen om tot inzicht te komen omtrent het al of niet erfelijke karakter van de vertoonde krankzinnigheid. Vervolgens moeten zij bij hun patiënten de lichamelijke afwijkingen bestuderen. De werking van vergiften als alcohol en de gevolgen van geslachtsziekten kunnen ook bij nakomelingen degeneratieverschijnselen teweeg brengen. Psychiaters moeten het dan ook als hun taak zien om, bijvoorbeeld door huwelijksadviezen, de erfelijkheid bij te sturen.

Winkler bestreed de idee dat men begrippen als krankzinnigheid zou kunnen definiëren. Er zijn geen bepaalde vaste maatstaven aan de hand waarvan men kan determineren of een individu al dan niet als krankzinnig moet worden geclassificeerd (ibid., p. 21.). Gezond, ziek, normaal of krankzinnig zijn geen wel te omschrijven toestanden; het zijn abstracties, ficties. Wie als een normale of als een krankzinnige persoonlijkheid moet worden bestempeld, is niet aan de hand van definities en andere algemene criteria vast te stellen. Winkler stelde in dit verband ook dat een normale persoonlijkheid een contradictio in terminis is. De term "normaal" verwijst naar een ideaalbeeld dat men hooguit als gemiddelde uit veel individuele gevallen heeft afgeleid, terwijl elke persoonlijkheid juist uniek is. " $\mathrm{Zij}$ is en blijft een eenige, een niet te vervangen verschijning" (ibid., p. 21). Geen enkel individu voldoet aan de norm. Elk bijzonder geval dient op zich zelf te worden beschouwd en alleen de klinische ervaring kan uitsluitsel geven.

Winkler had met name bezwaar tegen abstracte definities in een situatie waarin aan een gezonde persoon wel toerekeningsvatbaarheid werd toegedacht en aan het zieke individu niet. Artsen kunnen wel aangeven welke gebreken in de organisatie van een persoon aanwezig zijn en uit welke lichamelijke en psychische verschijnselen dit blijkt. Zij geven aan waar de afwijking van de norm groot is, maar het toepassen van een sociale categorie als toerekeningsvatbaarheid behoort volgens Winkler niet tot hun competentie. Ontoerekeningsvatbaarheid is net zomin als krankzinnigheid te omschrijven aan de hand van een aantal algemene medisch-wetenschappelijke criteria. 
Toen hij in 1893 aldus zijn mening gaf over de aard van geneeskunde, over het ziektebegrip en het klinisch oordeel, klonken bij Winkler de ideeën door uit de bovenbeschreven eerste fase in de wending tot de organicistische geneeskunde. Het individuele karakter van de ziekteverschijnselen, die door aanleg en omstandigheden worden bepaald, alsmede de individualiserende benadering aan het ziekbed, komen duidelijk naar voren.

Het belang van de psychiatrie in de opleiding tot geneeskundige werd door Winkler verbonden met de geldigheid van de stelregel "leer individualiseren" Deze maxime sloot zijns inziens aan op de recente groei van kennis in de geneeskunde en gold voor de geneeskunde in haar geheel. In de neurologie en in de psychiatrie, daar waar de uitingen van het zenuwstelsel worden bestudeerd, treedt de zelfstandige betekenis van het individu het scherpst aan de dag. De belangrijkste reden om de psychiatrie op te nemen als verplicht leervak aan de universiteit, was volgens Winkler dan ook dat: "(...) de uitoefening der geneeskunst zonder een tamelijk groote kennis der psychiatrie gebrekking blijft, omdat de geneesheer, zoolang als individualiseeren zijn taak is, eo ipso psychiater moet zijn" (ibid., p. 9).

Winklers levenswetenschappelijke oriëntatie blijkt tevens uit zijn opvatting van het individu als georganiseerd geheel en zijn belangstelling voor die onderzoeksthema's, die de levenswetenschappelijke geneeskunde van belang vond: regeneratie, differentiatie en groei, de wisselwerking tussen bouw en functie, en reproductie.

Toen Winkler zijn loopbaan als neuroloog begon, werd deze tak van wetenschap beheerst door de lokalisatieleer. Functies werden gekoppeld aan bepaalde organen: verschil in bouw zou corresponderen met verschil in functie. Winkler heeft veelvuldig het thema van de lokalisatie van psychische vermogens besproken (Winkler, 1909, 1912, 1915, 1929). Zijn organicistische achtergrond kwam in zijn discussies met de aanhangers van de lokalisatiegedachte duidelijk naar voren. Winkler constateerde dat het praktische resultaat van de "éénzijdige en stellig onjuist doorgevoerde lokalisatie-leer" de hersenchirurgie was, waaraan hij overigens nog wel een zekere waarde toekent. Er zijn door haar wel tal van mensenlevens gered, die zonder haar verloren waren, zo gaf hij toe (vgl. Winkler, 1912, p. 14). Maar nu - in 1912 - wordt de lokalisatieleer in toenemende mate geconfronteerd met problemen. Het standpunt van de praktijk wordt belangrijker en juist in de praktijk wordt betwijfeld of de lokaliserende benadering wel de juiste is, aldus Winkler. Uit het onderzoek blijkt immers steeds duidelijker dat organismen zich als een geheel verweren tegen ziekteoorzaken. Het is in de neurologie - ten aanzien van het zenuwstelsel - vruchtbaarder gebleken om de werking te begrijpen vanuit de voorstelling van een synthese dan aan de hand van de lokalisatieprincipes (vgl. ibid., p. 19). Winkler concludeerde dat er in de neurologie behoefte was aan integrerende beschouwingen, aan een integrale summatie, een term die hij aan de fysioloog Ch. S. Sherrington (1857-1962) ontleende. 
Winkler wilde niet volledig afstand doen van de lokalisatiegedachte, maar hij wilde wel de relativiteit ervan beklemtonen. "Het localisatie-beginsel blijft als goed geconstateerd feit zijn beteekenis behouden. Maar het is iets relatiefs, iets ondergeschikts geworden. Daarnaast staat een niet localiseerbare functie, die bemiddelend en verbindend werkt. $\mathrm{Zij}_{\mathrm{j}}$ is de functie van een substraat, dat zich in zijn bouw kenmerkt door een oneindig groote veelheid van betrekkelijk eenvoudige elementen, die een alom samenhangend geheel vormen, dat tusschen en in de organen zich bevindt, waar gelocaliseerde functies aan ver gedifferentieerde elementen zijn toevertrouwd. Aan localisatie der functie in dit substraat, hetzij in tijd of in plaats, valt niet te denken. Wij zijn gedwongen om de verbinding, de onveranderde bewaring, de reproductie, de inhibitie, de diaschisis, de regulatie der gelocaliseerde functies, als niet localiseerbare eigenschappen van het zenuwstelsel aantezien" (Winkler, 1912, p. 21). Deze onderschikking van specifieke functies aan een niet te lokaliseren algemene functie treedt overal in de levende natuur aan de dag. Deze algemene functie is volgens Winkler bij alle meer elementaire bouwelementen aanwezig. $\mathrm{Zij}$ is de draagster der reproductieve eigenschappen en wordt overal aangetroffen waar leven is (vgl. ibid., p. 29).

Winkler was met name geïnteresseerd in de ontwikkeling van het zenuwstelsel en de functionele samenhang daarbinnen. In het voorwoord bij het eerste deel van zijn Handbock der neurologie van 1917 stelde hij dat de clinicus voor alles verlangt om functionele begrippen aan de vormbeschrijving te verbinden. Kennis van de bouw van het zenuwstelsel is zeker nodig om aan het ziekbed werkzaam te zijn, maar deze is niet toereikend. De clinicus ziet immers het zenuwstelsel bovenal als functioneel geheel. De benadering die Winkler kiest om het zenuwstelsel te bespreken sluit op deze klinische behoeften aan. Hij beklemtoont het belang van het overkoepelende functionele gezichtspunt voor de neuroloogpsychiater. Analyse werd door hem verbonden met integrerende summatie. Enerzijds had Winkler dus oog voor het belang van een analyserende benadering in de neurologie, die resulteert in vormbeschrijvingen. Anderzijds achtte hij het onontbeerlijk dat het zenuwstelsel als functioneel samenhangend geheel wordt gezien (vgl. Winkler, 1917. p. VIII).

In sommige opzichten stelde Winkler zich gereserveerd op tegenover een levenswetenschappelijk concept van geneeskunde. Dit blijkt bijvoorbeeld in zijn intreerede te Amsterdam uit 1896, waarin hij sprak over de doelmatige beweging in de natuur (Winkler, 1896a). Hij constateerde dat biologen "het vermogen om op invloeden van buiten te antwoorden met doelmatige beweging" aangrijpen om een principieel onderscheid aan te brengen tussen dode en levende natuur (vgl. ibid., p. 6). Aan het concept doelmatigheid verbinden deze biologen vervolgens allerlei conclusies ten aanzien van de levende natuur, die Winkler ongeoorloofd acht. Hij treedt met hen in discussie via een analyse van het begrip doelmatigheid. Aan het begrip doelmatigheid kunnen verschillende betekenis- 
sen worden gehecht, aldus Winkler. Enerzijds is de bewuste handeling van de mens, de beweging die door de wil tot handelen wordt voorafgegaan, het summum van de doelmatige beweging in de natuur. Toch is doelmatigheid niet synoniem met bewustzijn. Onbewuste verrichtingen, automatismen en reflexen bijvoorbeeld, kunnen eveneens doelmatig genoemd worden. Deze vorm van doelmatigheid achtte Winkler ook voor de neurologie van belang. Maar men moet zich hierbij bewust zijn van de beperkingen. Het was zijns inziens niet juist om op grond van het begrip doelmatigheid uitspraken te doen over de aard en de betekenis van het bewustzijn. Deze vallen - Winkler citeerde hier met instemming het bovengenoemde 'ignorabimus' van Du Bois-Reymond - buiten het gebied van de natuuronderzoeker (vgl. ibid., p. 27).

Winkler ging ook behoedzaam om met de door het neo-vitalisme geinspireerde stelling dat er aan de principiële verschillen tussen organismen en machines op methodologisch niveau recht moeten worden gedaan. Hij erkende weliswaar dat een levend organisme nooit met een machine zal kunnen worden vergeleken. Maar hij betwijfelde of dit zou moeten impliceren dat men de natuurwetenschappelijke methoden verwerpt. Hij gaf toe dat volgens de huidige inzichten elke "afdeeling van wetenschap" - de natuurwetenschappen aan de ene kant en de levenswetenschappen aan de andere kant - haar eigen grondslagen heeft. Maar hij wilde daaraan niet de consequentie verbinden dat niet ooit beide tot éénzelfde grondslag zouden worden teruggevoerd: "Het gemis van een bewijs voor het monisme mag echter nooit als bewijs voor een even onbewezen dualisme of pluralisme gelden" (Winkler, 1912, p. 31). Ten opzichte van dergelijke fundamentele vragen nam Winkler een agnostische houding in. Hoe het ook mocht zijn, de waarde van de natuurwetenschappelijke methoden behoefde volgens Winkler niet ondermijnd te worden door de principiële verschillen tussen de dode natuur, de levende natuur en de mens. Hij keurde het dan ook af dat men binnen de levenswetenschappen zomaar de "goed gefundeerde methoden der natuurwetenschappen" de rug wilde toekeren.

Evenals andere aanhangers van een levenswetenschappelijk concept van geneeskunde stond Winkler sceptisch tegenover uitgesproken neo-vitalistische denkbeelden. Zo bekritiseerde hij verklaringen die steunen op concepten als entelechie en distantieerde zich uitdrukkelijk van die vormen van neo-vitalisme die met veel omslag van woorden pretenderen een oplossing te geven voor onbewijsbare kwesties, zoals het vraagstuk van de doelmatigheid in de levende natuur. Ook hier parafraseerde hij Du Bois-Reymond: "Wij weten het niet en zullen het waarschijnlijk ook nooit weten"(Winkler, 1912, p. 31). Het was, volgens Winkler, niet aan de natuuronderzoeker om de vraag naar het doel van de natuur te beantwoorden. En men kon zijn onkunde ten opzichte van dergelijke vragen beter eerlijk bekennen. 
De lokalisatieleer had tot gevolg dat fysiologen psychologische termen in hun vocabulaire opnamen. Zolang men van mening was dat psychologische vermogens als gevoel en perceptie lokaliseerbaar zijn, kon de fysiologie zonder in inconsistenties te geraken zich van dergelijke termen bedienen. Dat was naar de mening van Winkler echter niet terecht. Ten aanzien van de vraag naar de relatie tussen psychische - waaronder bewuste - verschijnselen en fysische of fysiologische verschijnselen, stelde hij zich op het standpunt van een methodisch parallellisme. De natuuronderzoeker ziet vanuit wetenschappelijk perspectief bewustzijn en reflectorische en automatische beweging als twee parallelrijen. Beide komen weliswaar niet los van elkaar voor, maar de samenhang onttrekt zich aan het kenvermogen. Men kan dan ook als wetenschapsbeoefenaar daar geen uitspraken over doen, aldus Winkler. Spiritualisme en materialisme zijn geen basis voor kennis, zij moeten wijken voor agnosticisme. Winkler schreef in 1896 in dit verband: "De geneesheer kent echter slechts beide bij elkander behorende reeksen van verschijnselen. Zijn taak als natuuronderzoeker zou vervuld zijn, als hij naast elken bewusten toestand een daarnevens bestaande verandering in de zenuwstof zou kunnen demonstreeren" (Winkler, 1896a, p. 9). Ook later vormde het parallellisme voor Winkler een werkhypothese; het garandeerde zowel voor de psycholoog als voor de fysioloog alle vrijheid en bood tegelijkertijd een samenwerkingsterrein, waarop beiden elkaar kunnen begrijpen en elkaar op hun waarde kunnen schatten (Winkler, 1918-1933 (1913); Winkler, 1915, p. 7). Het onderzoeksobject, een bepaald verschijnsel dat de arts aantreft, wordt als het ware van twee kanten bekeken. Beide typen van onderzoek vormen elkaars tegenhanger.

Winklers parallellisme was uitdrukkelijk een methodische veronderstelling, die niet in tegenspraak is met het feit dat voor Winkler het individu de centrale categorie blijft. Functies bestaan bij de gratie van het geheel. De mens als eenheid, weliswaar opgebouwd uit talloze relatief onafhankelijke organen, stond voor hem voorop (Winkler, 1909, p. 83). Juist aan het ziekbed blijkt dat patiënten integraal reageren op een stoornis.

Als het individu een handeling voltrekt, werken verschillende componenten samen in een "symphonie kinétique". De opbouw van de verschillende functies is in de loop der tijd opgebouwd. Daarbij zijn ze aan een bepaald substraat gebonden geweest, ze hebben een eigen lokalisatie gehad, maar deze lokalisatie moet, zoals gezegd, als relatief worden gezien. "Het individu, dat op een gegeven oogenblik die symphonie bespeelt, gebruikt daarvoor het geheele zenuwstelsel, dat achtereenvolgens bij den opbouw der symphonie betrokken was" (Winkler, 1929, p. 1815). Deze symfonie kan door een interne of externe factor langzaam of plotseling worden verwoest. Vervolgens wordt er echter een nieuwe gecomponeerd uit de brokstukken van de oude, aldus Winkler, dat is het ziektegevolg (vgl. ibid.). Met deze beschrijving van ziekte, die dateert uit de periode na zijn afscheid als hoogleraar, bleef Winkler overigens dicht bij de boven geciteerde opvatting daarvan in zijn intreerede. 
Op latere leeftijd verdedigde Winkler zijn wetenschapsconcept tegen onder andere de psychoanalyse en Jaspers' "verstehende" psychologie. Dan blijkt duidelijk dat hij als vertegenwoordiger van de levenswetenschappelijke geneeskunde de natuurwetenschappelijke methoden niet heeft willen verlaten. In zijn afscheidsrede bekritiseerde hij S. Freud (1856-1939). Diens werk maakt op de leek wel indruk, maar: "(...) deze romantiek (...) voldoet niet aan de eischen van strenge wetenschappelijke critiek" (Winkler, 1925, p. 11). De psychoanalyse zag hij als een opeenstapeling van onbewezen en onbewijsbare hypothesen. Winkler sprak dan ook de veronderstelling uit, dat dit stelsel van weinig belang zou zijn voor de toekomst der psychiatrie.

Op dezelfde plaats verdedigde hij zijn eigen visie tegenover Jaspers. Diens kritiek op de anatomisch-fysiologische methode wimpelt hij af. Jaspers trekt ten strijde tegen de idee dat psychopathologie hersenpathologie zou zijn. Deze dogmatische stelling is ook volgens Winkler onhoudbaar: "Ook mij schijnt het toe, dat slechts lijden van het geheele organisme zich psychopathologisch kan uiten" (ibid., p. 12). In de anatomisch-fysiologische benadering wordt er daarentegen van uitgegaan dat een organisme een geheel is, aldus Winkler, en realiseert men zich dat de clinicus altijd alleen maar functieveranderingen waarneemt. Om die veranderingen te begrijpen is kennis van anatomie, pathologische anatomie en fysiologie noodzakelijk. Het was daarbij volgens Winkler volstrekt onnodig om naast causale relaties ook nog "begrijpelijke relaties" in te voeren in de psychopathologie. "Alsof het mogelijk is zich 'intevoelen' in het psychisch leven van een ander" (ibid., p. 13).

Winkler was vooral een klinisch neuroloog, die zijn zieken wilde behandelen via een psychiatrie die gebaseerd is op een biologische grondslag. Hij hoopte dan ook dat hij in 1925 zou worden opgevolgd door iemand die de psychiatrie vanuit een biologisch standpunt wenste te doceren, die hersenanatomisch geschoold was en de door hem geleide wetenschappelijk onderzoekingen zou kunnen voortzetten. In deze verwachting werd hij teleurgesteld door de minister van Onderwijs, Kunst en Wetenschappen die, tegen de voordracht van de Utrechtse universiteit in, L. Bouman (1869-1936) benoemde. Bouman was hersen-anatomisch niet geschoold en Winkler vreesde dan ook dat te Utrecht de neurologie niet meer op anatomische grondslag zou worden gedoceerd (vgl. Winkler, 1947, p. 156). Op psychiatrisch gebied liepen hun meningen ver uiteen. Bouman wordt immers beschouwd als de peetvader van de psychologische psychiatrie (vgl. Van Belzen \& Ter Meulen, 1988).

$\mathrm{Na}$ zijn emeritaat heeft Winkler nog enige jaren wetenschappelijk onderzoek verricht en publiceerde hij de resterende drie delen van zijn Handboek der neurologie. In 1933 kwam het vijfde en laatste deel uit. Hierna heeft Winkler zich teruggetrokken uit het wetenschappelijk onderzoek. 
In deze schets van zijn opvattingen komt Winkler naar voren als een belangrijk onderzoeker. Hij trad vooral met vakgenoten in discussie over de grondslagen van de geneeskunde. De volgende representant van de geneeskunde in de organicistische periode, Barge, richtte zich tot een groter publiek. Winkler sprak als wetenschapper tot zijn medewetenschappers, Barge sprak als katholieke arts tot een bredere kring van intellectuelen. Hij zette zich op maatschappelijk terrein in voor de verbreiding van een bepaalde wetenschapsopvatting, die door zijn levensovertuiging werd gevoed. Zowel Barge als Winkler hebben echter op een eigen wijze een belangrijk stempel gedrukt op het onderwijs in en de beoefening van de geneeskunde in Nederland.

\subsection{Joannes Antonius James Barge (1884-1952)}

Joannes Antonius James Barge is geboren in 1884 te Semarang. Na een studie aan de Gemeentelijke Universiteit te Amsterdam werd hij in 1909 tot arts bevorderd. In de daaropvolgende tien jaar werkte hij bij de anatoom L. Bolk (1866-1930) te Amsterdam, eerst als assistent, vervolgens als prosector en als privaat-docent. In 1912 promoveerde hij in Amsterdam op een antropologisch onderzoek van Friese en Marker schedels.

In 1919 werd Barge benoemd tot hoogleraar in de ontleedkunde en de embryologie aan de Rijks-Universiteit te Leiden. Hij zou in deze positie - weliswaar met een onderbreking in de Tweede Wereldoorlog - daar gedurende 30 jaar werkzaam zijn. Op 25 februari 1949 nam hij afscheid als hoogleraar. Barge is op 18 februari 1952 overleden.

Barge heeft niet alleen door zijn 30 -jarig hoogleraarschap een belangrijk stempel gedrukt op de Nederlandse geneeskunde in de levenswetenschappelijke periode. Ook door zijn bijdragen aan het leerboek "Handleiding tot de praktische ontleedkunde", dat in vele drukken is verschenen, en door zijn bewerking van een deel van het "Nederlandsch leerboek der beschrijvende ontleedkunde" heeft hij daarop veel invloed gehad. Naast publicaties over anatomische bevindingen, heeft Barge veelvuldig geschreven en gesproken over meer theoretische onderwerpen en over de geschiedenis van de geneeskunde. De vraag naar de grondslagen van de geneeskunde bracht hij keer op keer ter sprake. Daarbij richtte hij zich zowel tot vakgenoten als tot een breder publiek. In de Tweede Wereldoorlog hield Barge, toen hij door de Duitse bezetter was gearresteerd, voor zijn medegevangenen bijvoorbeeld voordrachten over de oorsprong en de betekenis van het leven (vgl. Van der Goes van Naters, 1995). Het was Barges bedoeling om velen te betrekken in de wijsgerige reflectie op de wetenschap. Hij betoonde zich hierbij een invloedrijk pleitbezorger van een levenswetenschappelijke geneeskunde. 
Barge was verder op maatschappelijk terrein zeer actief. Hij zette zich met name in voor de katholieke emancipatie. Aan het eind van de jaren twintig en in het begin van de jaren dertig was hij voorzitter van de "Algemeene Vereeniging tot het Bevorderen der Wetenschap onder de Katholieken in Nederland". In zijn Redes van den Vooritter besprak hij herhaaldelijk de omslag van materialisme naar vormen van neo-vitalisme in de denkbeelden en beschouwingswijzen binnen zijn vakgebied. Opmerkelijk is dat dit door hem werd aangeduid als de biologie. Daarbij schetste hij de moderne ontwikkelingen in de weefselleer, in de embryologie en in de vergelijkende anatomie (vgl. o.a. Barge, 1949 (1944), pp. 200-206 (oorspr. 1926); ibid., pp. 207-215 (oorspr. 1927); ibid., pp. 315 321 (oorspr. 1931). In 1937 werd Barge afgevaardigde van de Rooms-Katholieke Staatspartij in de Eerste Kamer.

Bij de aanvaarding van het hoogleraarsambt op 7 mei 1919, sprak Barge een rede uit getiteld "Vorm en functie", waarin hij twee thema's aanstipte die hem na aan het hart lagen (Barge, 1919). Deze waren enerzijds de vraag "Wat is het leven?" en anderzijds de relatie tussen vorm en functie. Sinds 1919 heeft hij herhaaldelijk geschreven en gesproken over deze twee medisch-theoretische onderwerpen. In de beantwoording van de vraag "Wat is het leven?" en in de visie op de onderlinge relatie tussen vorm en functie kreeg Barges levenswetenschappelijke opvatting van de geneeskunde gestalte. Bij de schets van Barges conceptie van de geneeskunde zal dan ook bij deze twee kwesties worden aangeknoopt.

Dat Barge de geneeskunde als een onderdeel der biologische wetenschappen beschouwde blijkt al uit zijn intreerede. Daarin gaf hij aan dat hij de menselijke ontleedkunde niet zozeer wilde zien als een complex van vormverhoudingen maar als: "(...) een zelfstandig onderdeel der biologische wetenschappen, dat een zeer bijzondere manifestatie van algemeene levensverschijnselen tot welomschreven object heeft, (...)" (Barge, 1919, p. 8). Op grond van deze bepaling was de centrale vraag in de geneeskunde, evenals in de overige biologische wetenschappen, die naar het "wezen des levens". De reflectie op de theoretische uitgangspunten in de geneeskunde diende volgens Barge dan ook aan te sluiten op de discussies in de wijsgerige biologie.

Barge schetste in zijn intreerede tevens zijn conceptie van het onderzoeksterrein dat hem was toegewezen. Hij omschreef het als de grondige studie van de vorm, waarin zowel het door functionele aanpassing verworvene als het eigene en principiële van de vorm moest worden nagespeurd (vgl. Barge, 1919, p. 24). De vorm van een levend organisme moest volgens Barge dan ook niet op zichzelf worden beoordeeld, maar altijd in verband worden gebracht met het bijbehorende functioneren. Hij was ervan overtuigd dat vorm en functie elkaar beïnvloeden. Twijfel aan de vormende invloed van de functie en, omgekeerd, aan de 
invloed van de vorm op de functie leek hem uitgesloten (vgl. ibid., p. 20). Ook later, in 1937, zou hij deze visie op de relatie tussen vorm en functie met kracht naar voren brengen: "Er kan derhalve geen sprake van zijn, dat de een den ander voortbrengt of voortgebracht heeft. Beide bestaan in het leven tezamen als elkanders noodzakelijk complement" (Barge, 1949 (1944), p. 476).

De vraag "Wat is het leven?" bracht Barge tot een bespreking van het onderscheid tussen de dode en de levende natuur. Deze verschillen op een essentieel punt van elkaar, zo meende Barge. De levende natuur onderscheidt zich van de dode natuur door haar, op organisatie berustende, vermogen tot reactie. "Ik ben van meening", zo stelde hij, "dat wij met groote stelligheid kunnen verzekeren, dat de verschijningsvorm der levende wezens niet alleen het resultaat is van de prikkels, die een hypothetisch, met geen enkele biologische ervaring strookend leven zonder individueelen verschijningsvorm zou hebben ondergaan, maar dat naast en met hetgeen de aanpassing aan en de reactie op invloeden van buiten aan den verschijningsvorm der levende wezens hebben bijgedragen, een eigen beginsel dezen vorm bepaalt. Het zijn voor alles de levensverrichtingen, die ons het leven als iets zelfstandigs en van het niet leven wezenlijk onderscheiden doen kennen en ook in vormverandering zich aan ons openbaren. Ook als men aan het leven iedere spontaniteit ontzegt en alle activiteitsverschijnselen tot reacties op van buiten af inwerkende prikkels terugvoert, bljif men genoodzakt deze activiteitsverschijnselen te doen uitgaan van een subject, dat naar zijn aard het vermogen tot reageeren bezit. De geaardheid van den drager der levensverschijnselen maakt zich aan ons kenbaar mede door zijn structuur. Het vermogen, de potentie tot reageeren is in de organisatie van het levende wezen gelegen" (Barge, 1919, pp. 22-23).

Aan de hand van dezelfde vraag naar de aard van het leven is Barge later nog veelvuldig ingegaan op het onderscheid tussen de dode en de levende natuur. In discussies met andere medici en wijsgerig biologen, poogde hij telkens op adequate wijze te omschrijven wat de eigen aard van de levende natuur uitmaakt. De in de vorige paragrafen geschetste levenswetenschappelijke opvatting van leven als doelmatigheid en integratievermogen treedt in Barges werk duidelijk aan de dag. Deze bepaling van het wezen van het leven had ook consequenties voor Barges vakgebied. De verbondenheid van vorm en functie werd verklaard doordat het organisme als individueel, levend geheel in wisselwerking staat met zijn omgeving. Ze volgde uit de overkoepelende omschrijving van leven als organisatie, reactie- en incasseringsvermogen. Ziekte, veroudering en dood worden, in het verlengde hiervan, gekenmerkt door een staat van uitputting, waarin het organisme geen weerstand meer heeft en het vermogen om zich te handhaven jegens schadelijke invloeden verloren gaat, met als gevolg dat het uiteindelijk bezwijkt (vgl. Barge, 1938b, p. 34). Deze processen behelzen zowel vormals functieveranderingen. 
Naar aanleiding van de specifieke levensverschijnselen als voeding, groei en voortplanting was het volgens Barge gerechtvaardigd om te veronderstellen dat het levende en het levenloze niet identiek zijn. Men kan op goede gronden volhouden dat er in het leven nog iets anders is dan louter fysisch-chemische krachten. Dit andere, dat specifiek is voor het leven, achtte Barge niet iets bijkomends. Door te erkennen dat het leven fundamenteel verschilt van het levenloze was men echter, aldus Barge, niet verplicht tot de aanname van een levenskracht die de fysische en chemische wetmatigheden vervangt of buiten werking stelt. Men wordt niet noodzakelijkerwijze vitalist als men het mechanicisme verwerpt en de gelijkstelling van de levende en dode natuur bestrijdt.

Barge stelde dat het vitalisme en het mechanisme beide een te eenzijdige visie bezitten op de wetenschappelijke verklaring. $\mathrm{Zij}$ bepleiten in het ene geval een onverantwoorde optelsom van natuurwetenschappelijk factoren en levenskracht, en in het andere een niet te handhaven reductie. Zij doen daardoor beide geen recht aan het kenmerkende aan het leven, nl. dat het een ondeelbaar geheel vormt. De fysiologie die zich richt op een steeds verdere analyse van de fysischchemische processen, heeft de onderzoeker niet één stap verder gebracht bij zijn studie naar het wezen van de functie, zo verklaarde hij. "Wij kunnen den vorm niet scheiden van de functie noch de functie ontleden in louter stoffelijke krachten en een levenskracht, noch den vorm doen uiteenvallen in iets bijkomstigs en iets wezenlijks. Het leven blijft een synthese tot een hoogere eenheid, die zich tegen iedere analyse in onmiddellijk waarneembare componenten verzet en in zooverre voor ons in verborgenheden is gehuld" (Barge, 1919, p. 24). Het leven is niet stof plus iets anders dat er buiten ligt, noch alleen stof. "Kenmerkend voor het leven is immers, dat het zelf handelt van binnen uit krachtens iets, dat met het stoffelijk substraat allerinnigst verbonden is en daarmede een eenheid uitmaakt" (Barge, 1938b, p. 22). "Leven" is de zijnswijze der organismen (vgl. Barge, 1938b, p. 22). Het geheel eigene van de levensverschijnselen duidde hij aan als de "immanente eigen werkzaamheid" of "immanente doelstreving". Zo wordt het meest wezenlijke waardoor het levende van het levenloze verschilt in de meest algemene termen en het meest stringent aangeduid, aldus Barge (vgl. Barge, 1938b, p.17).

Vitalisten hadden het wezen van het leven - volgens Barge ten onrechte - steeds gezocht in iets dat buiten de stof ligt. Toch hebben de neo-vitalisten door hun nadruk op de totaliteit, op de "Ganzheit", van het organisme een belangrijke invloed gehad op de biologie. De uitwerking van de totaliteitsgedachte in de biologie door het holisme was volgens Barge niet zonder gebreken, maar daarom was zij nog niet zonder betekenis. Zij had immers het inzicht doen doorbreken dat men zich er in de biologische wetenschappen rekenschap van moet geven dat levensverschijnselen uitgaan van individuen (vgl. Barge, 1936, p. 99). Daarenboven had het velen tot een theoretische verwerping van het mechanicisme 
gebracht (vgl. Barge, 1936, p. 109). Barge maande echter wel ten aanzien van de begrippen totaliteit en "Ganzheit" tot een houding van onafgebroken waakzame kritiek.

Volgens Barge karakteriseerden de begrippen "Gestalt" of "Ganzheit" het specifieke van de levende natuur niet voldoende, omdat ook machines een geheel kunnen vormen. Alleen een bepaald begrip van totaliteit, waarin de functionele eenheid van het geheel wordt gekenmerkt doordat deze functies samenwerken voor het welzijn van het geheel, gaf daarvan een bevredigende omschrijving. De factor tijd speelt bij organismen een cruciale rol. "Het organisme immers is niet, zooals een machine, een statische constructie", zo stelde Barge, "maar een voortdurend zich wijzigende organisatie van functies, die op eenig doel is gericht en in dit gericht zijn door haar verleden wordt beïnvloed. Zoodoende staat de werkzaamheid van het levend organisme in een zekere verhouding zoowel tot het verleden als tot de toekomst" (Barge, 1936, p. 99). Met de term "Ganzheit" was geen onderscheid te maken tussen het anorganische en het leven. Daarom was deze term in de biologie ook gevaarlijk, aldus Barge: "Met de beste bedoelingen onderneemt men een grootsch lijkende synthese en komt, eer het zich bewust te zijn bij het meest elementaire materialisme uit" (Barge, 1936, p. 108).

Waardoor het leven wel wordt onderscheiden is, naast de factor tijd, dat het "ganzheitbildend" en "ganzheiterhaltend" is. Het werkt uit zich zelf op zich zelf en vormt en onderhoudt op deze manier zelf de "Ganzheit" (vgl. ibid.). Teneinde het fundamentele verschil tussen levende en dode natuur verder te verduidelijken contrasteerde Barge machines met organismen. Machines zijn wel doelmatig, maar ook passief. Hun werking komt niet voort uit henzelf, deze is aan iets anders ontleend en op iets anders gericht. Bij organismen zijn daarentegen niet alle werkingen op deze wijze overdrachtelijk, al zijn ze natuurlijk wel onderworpen aan de natuurwetten. Hij stelde: " (...) het leven is gekenmerkt door 'zelfwerking' en de doelmatigheid van deze zelfwerking is niet transient, niet overdrachtelijk, maar immanent of wederkeerig" (Barge, 1938b, p. 15). Elders karakteriseerde hij het onderscheid als volgt: "Wat het leven kenmerkt is die geheel eigen vorm van doelmatigheid, waarbij de van het subject uitgaande werking op dit subject zelve gericht is en tot de volkomenheid van dit subject bijdraagt; het is de hiervoor genoemde inwendige, aan geen menschelijk vernuft ontleende, immanente doelmatigheid" (Barge, 1935, in: Barge, (1944) 1949. p. 432).

Barge besprak herhaaldelijk de opvattingen van de Utrechtse fysioloog H.J. Jordan (1877-1943). Hij nam onder andere diens schets van het verschil tussen machines en organismen over. Machines en levende wezens kan men beide beschouwen als georganiseerde gehelen, maar in Jordans visie zijn zij qua structuur niet gelijksoortig. Machines en organismen kunnen beide als een causale structuur worden beschreven. Fen machine is evenwel een open causale structuur, omdat de schakeling der onderdelen, die in een causale keten verloopt, altijd kan 
worden onderbroken. Een machine heeft twee uiteinden, hij wordt bediend en levert een product af. Een organisme vormt daarentegen een gesloten causale structuur, waarbinnen intercausale betrekkingen bestaan. ledere werking die van enig onderdeel van het organisme uitgaat doet haar invloed op ieder ander onderdeel van het organisme gelden. Barge sloot zich aan bij Jordan toen hij stelde: "Het levend organisme is geen open causale structuur, maar een geslotene en juist in dit gesloten zijn ligt het essentiëele ervan, dat wij boven als de op zich zelf gerichte zelfwerking hebben aangeduid" (vgl. Barge 1938b, p. 19). Niet alle werkingen zijn evenwel te beschouwen als zelfwerking. De immanente zelfwerkzaamheid kwam volgens Barge alleen voor bij die verschijnselen, die specifiek zijn voor het leven, zoals voeding, groei en voortplanting.

De bovenstaande karakterisering van de eigen aard van de levende natuur ten opzichte van de machine had consequenties voor de wijze waarop de anatoom tegen zijn wetenschappelijk object aankijkt. Het levende organisme moest als geheel beschouwd worden. Barge formuleerde het als volgt: "De onderdeelen, met behulp waarvan een machine wordt opgebouwd, zijn losse deelen, die elk voor zich afzonderlijk worden vervaardigd en daarna, volgens een tevoren opgemaakt plan op eenigerlei wijze met elkander worden verbonden of in aanraking gebracht. Uit de samenvoeging der deelen wordt zoodoende het geheel opgebouwd. Ook na de samenvoeging blijven de deelen ten opzichte van elkander begrensd: men kan de machine geheel demonteeren en opnieuw weer opbouwen. Bij het levend organisme is het gansch anders. Hier bestaan geen afzonderlijke, scherp afgegrensde deelen" (Barge, 1947 (1941), pp. 8-9). Het leven wordt gekenmerkt door eenheid en organisatie, volgens Barge. Het is een synthese tot een hogere eenheid die niet in een analyserende beschouwing te verklaren is. In het levende organisme hangt alles met alles samen, er bestaat geen scheiding van onderdelen. Het organisme is van begin af aan, vanaf de bevruchte eicel, een geheel waarvan de delen organisch met elkander verbonden zijn (vgl. Barge, 1938a, p. 21; Barge, 1947 (1941), p. 9). Het onderscheid tussen de organen en tussen andere lichaamsdelen is een kunstmatig, door de anatoom getroffen onderscheid.

Deze visie op het wezen van het leven heeft zijn weerslag op de relatie tussen vorm en functie. De harmonische betrekking tussen vorm en functie als zodanig was volgens Barge niet iets specifieks voor het leven. Maar bij levende organismen bezit het wel een specifieke karakter. Barge beschrijft het als volgt: “(...) dat het levend organisme het vermogen bezit om, wanneer wijziging van uiterlijke of inwendige omstandigheden voor het zich handhaven van het organisme een wijziging van functie noodzakelijk maakt, de gewijzigde functie tegelijk met den daarbij behoorenden gewijzigden vorm te vertoonen. De openbaring van dit vermogen is een specifieke levensuiting, het is de actio immanens, het is de werking uit zich zelve op zich zelve, de werking der gesloten causale structuur, het is het leven zelf" (Barge, 1947 (1941), p. 17v). 
Uit deze opvatting omtrent het wezen van het leven trok Barge, evenals de eerder genoemde levenswetenschappelijke geneeskundigen, conclusies ten aanzien van een geẽigende wetenschappelijke verklaringswijze. Het mechanicisme wees hij af. Hij stelde een vorm van wetenschap voor die recht zou doen aan het gegeven dat de levende natuur van een ander zijnsorde is dan de dode natuur.

Bij de uitwerking van zijn wetenschapsconcept refereerde Barge wederom aan de ideeên van Jordan. Ook Jordan bekritiseerde de experimentele analyserende benadering van de natuurwetenschap. $\mathrm{Hij}$ zag de biologie als een systeemwetenschap, die zich richt op "intercausale systemen" of "causale structuren" en niet op afzonderlijke betrekkingen tussen oorzaak en werking in ieder detailproces. Om recht te doen aan de kenmerken van de organische causale structuren stelde Jordan ook een nieuw causaliteitsbegrip voor, de "geordende causaliteit". Daarenboven wees hij de teleologie niet af.

Barge stond positief tegenover dergelijke ideeển. Maar Jordans verdere uitwerking van deze principes was voor Barge niet acceptabel. Jordan was namelijk van mening dat men de causaal-analytische methoden zou kunnen aanvullen met een synthese die de beperkingen van de analyserende methode opheft. Barge liet echter zien dat men bij een gesloten causale structuur niet eerst elke werking afzonderlijk en vervolgens de som daarvan kan vaststellen. Binnen een gesloten causale structuur beinvloedt elke werking alle andere, alle werkingen zijn met elkaar vervlochten. Jordan was naar de mening van Barge niet consequent genoeg, hij bleef nog te zeer hangen aan het natuurwetenschappelijke verklaringsmodel. Jordan miskende dat als men het organisme werkelijk als gesloten causale structuur beschouwt, men de analyserende benadering overboord moet zetten. In de woorden van Barge: "Wanneer men eenmaal het inzicht heeft, en mijnerzijds deel ik dit inzicht volkomen, dat het levend organisme een gesloten causale structuur is, is het uitgesloten, dat men èn de causale structuur kent, èn tegelijk de werking der oorzaken binnen deze gesloten structuur" (Barge, 1936, p. 104).

Evenals de eerder beschreven levenswetenschappelijke geneeskundigen bepleitte Barge een herziening en een aanvulling van het causaliteitsbegrip. Alleen zo kon men in de geneeskunde recht doen aan de eigen aard van haar object, het levende organisme. Bij de bestudering van het leven, de synthese tot een hogere eenheid, schoot het natuurwetenschappelijke causaliteitsbegrip, de "causa efficiens" zijns inziens tekort: "Tegenover het organische met zijn immanente werking en gesloten causale structuur was deze, de structuur als gegeven aanvaardende, op de efficiënte causaliteit ingestelde geesteshouding niet toereikend" (Barge, 1947 (1941), p. 22). Zij voldeed volgens Barge niet omdat het belang van de functie wordt miskend. In de natuurwetenschappelijke beschouwingswijze was de vorm primair en de functie secundair. De onderzoeker wordt echter, wanneer hij de levende natuur onderzoekt op een wijze die aansluit op de in 
het anorganische gevolgde beschouwingswijze, geconfronteerd met de omnogelijkheid daarvan. Ten aanzien van de levende natuur kan men niet primair van de structuur uitgaan, aldus Barge, omdat: " (...) een bepaalde structuur bij het leven niet bestaat. Er is niets anders dan een permanent functionneerend, op zich zelf inwerkend geheel, waarbij de functie de vorm voortdurend verandert" (Barge, 1937, in Barge 1949 (1944), p. 480). Als men daarentegen een finaal causaliteitsbegrip zou hanteren, was de functie primair en de vorm secundair. Volgens Barge moesten beide perspectieven verenigd worden aangezien in een correcte, dat wil zeggen levenswetenschappelijke, vorm van medisch onderzoek niet alleen de bouw, de structuur, maar ook de functie betrokken moesten worden. Organismen leven immers, ze passen zich aan aan de omstandigheden. Hierbij gaan wijzigingen in vorm en in functie, hand in hand.

De teleologische beschouwing komt niet in conflict met de fysische causaliteit, aldus Barge. De zelfwerkzaamheid was niet een kracht die de natuurwetenschappelijke causaliteit tegenwerkt of buiten werking stelt. Dat zou een vitalistische gedachte zijn en deze werden door Barge, zoals wij in het bovenstaande zagen, expliciet verworpen. De concrete toepassing van de teleologische benadering in de praktijk van het wetenschappelijk onderzoek krijgt gestalte in de aandacht voor zowel vorm als functie. Barge bestreed niet dat organismen onderworpen zijn aan de fysisch-chemische wetmatigheden. Hij constateerde dat vrijwel niemand meer betwijfelt: “ $(. .$.$) dat in zijn uitvoering alle zintuiglijk waarneembaar$ gebeuren ook bij het leven causaal door natuur- en scheikundige wetten is bepaald" (Barge, 1938b, p. 23). Maar anderzijds stelde hij dat het leven wel zeer gebrekkig wordt weergegeven in het natuurwetenschappelijk perspectief. Hij bracht in dit verband naar voren dat: “(...) al wat het leven in mensch, dier of plant aan zintuiglijk waarneembaar gebeuren biedt, in zijn uitvoering weliswaar causaal door natuur- en scheikundige wetten is bepaald, maar dat anderzijds de physico-chemische verklaring dezer zintuiglijk waarneembare verschijnselen hun wezensinhoud niet uitput" (Barge, 1935, p. 435). De vervlechting van vorm en inhoud, die kenmerkend is voor levende organismen, wordt in een natuurwetenschappelijke optiek uit het oog verloren.

Barge wilde door zijn geschriften de bezinning op de grondslagen van de biologische wetenschappen bevorderen. Door te vragen wat het leven is, werd de geneeskunde zich bewust van haar fundament. De bepaling van het wezen van het leven leidde tot het inzicht dat vorm en functie nauw verbonden zijn. Hieraan verbond Barge de conclusie dat de geldigheid van de natuurwetenschappelijke benaderingswijze ten aanzien van levensverschijnselen beperkt is. Ze moest worden aangevuld met finale beschouwingen, die recht doen aan het gegeven dat het organisme een gesloten causale structuur is die een op zichzelf gerichte zelfwerking vertoont. 
Barges redenering volgde een binnen de levenswetenschappelijke geneeskunde bekend stramien, dat hierboven ook is beschreven. Hij vertrok in die zin vanuit een ontologisch standpunt, dat hij het levende organisme van een andere zijnsorde verklaarde dan de dode natuur. Aan deze bepaling verbond hij op methodologisch niveau de consequentie dat het mechanicisme niet voldoet. Men mocht de verschillen tussen de levende en de dode natuur in de biologische wetenschappen niet veronachtzamen.

In het volgende hoofdstuk zal worden aangegeven dat de antropologische geneeskunde van mening was dat het onderscheid tussen de dode en de levende natuur onvoldoende was om de eigen aard van de wetenschappelijke benadering van de geneeskunde aan te duiden. Men zou beargumenteren dat het object van de geneeskunde, de mens, niet over een kam geschoren mag worden met de levende natuur. 


\section{Geneeskunde als menswetenschap}

\subsection{Een antropologische geneeskunde}

In de vorige hoofdstukken zijn de ontwikkelingen en verschuivingen in het zelfbeeld van de geneeskunde beschreven in de periode van 1840 tot de eerste helft van de jaren dertig in de twintigste eeuw. Dat geneeskunde een wetenschap is, werd in eerste instantie verdedigd vanuit de natuurwetenschappelijke conceptie van de geneeskunde. Het biologische wetenschapsideaal drong vervolgens de natuurwetenschappelijke definitie van de geneeskunde op de achtergrond. De ontoereikendheid van causaal-analytische methoden werd allerwegen benadrukt. De visie op organismen als individuele georganiseerde gehelen leidde tot een herziening van de wetenschappelijke werkwijze. De natuurwetenschappelijke benaderingswijze werd aangevuld met teleologische beschouwingen. Begrippen als teleologie, finaliteit, constitutie en individualiteit waren trefwoorden in de geneeskunde die afstand had gedaan van de natuurwetenschappelijke oriëntatie en zichzelf beschouwde als levenswetenschap.

Aan het eind van de jaren twintig werd echter door velen de organicistische opvatting van geneeskunde als levenswetenschap op haar beurt onbevredigend geacht. Vanaf de jaren dertig tot in de jaren vijftig kan men spreken van een antropologische of menswetenschappelijke oriëntatie binnen de geneeskunde. Deze wist de levenswetenschappelijke opvatting niet totaal van het toneel te verdrijven. Dat blijkt al bij de bespreking van de opvattingen van Barge, die deels uit dezelfde periode stammen. Maar de antropologische oriëntatie beheerste wel in belangrijke mate de discussie over de aard van geneeskunde. De antropologische opvatting van geneeskunde baseerde zich expliciet op een wijsgerig mensbeeld. Men omschreef de zijnswijze van de mens als persoon-zijn en stelde dat de geneeskunde hier niet aan voorbij kan gaan. Zij moest zich, als zij iets van ziekte dacht te kunnen begrijpen, niet richten op het functioneren van levende organismen maar op de zieke mens, op de persoon. De geneeskunde kon dan ook geen biologie zijn, zij profileerde zich als menswetenschap (vgl. Siebeck, 1931, p. 2171).

De wending tot een menswetenschappelijk concept van geneeskunde paste in haar beginjaren binnen het kader van de al eerder gesignaleerde, binnen allerlei takken van wetenschap groeiende, aandacht voor de individualiteit. $\mathrm{Na}$ vele jaren van generaliseren en universaliseren zetten wetenschapsbeoefenaars vraagtekens bij de nomologische benadering van de natuurwetenschappen. Het materialisme en het positivisme werden verworpen omdat zij geacht werden bij 
te dragen aan een alom geconstateerd cultureel verval (vgl. Ringer, 1969; Leichtman, 1979). Causaal-analytische methoden zouden leiden tot een gefragmenteerd wereldbeeld; de vraag naar de zin van het bestaan leek niet meer gesteld te kunnen worden. Men onderzocht, zoals ook in het vorige hoofdstuk over de levenswetenschappelijke geneeskunde is geschetst, wat men vanuit de begrippen individu en eenheid tegenover het gangbare concept van wetenschap kon stellen. Er deed zich aan het begin van de twintigste eeuw op uiteenlopende terreinen een ingrijpende stijlverandering, een verschuiving van perspectief, voor. Het probleem van de individualiteit trad bij deze herbezinning steeds dringender op de voorgrond (vgl. o.a. Straus, 1926, p. 27 en p. 36).

Binnen de organicistische conceptie van de geneeskunde werd sinds het eind van de negentiende eeuw het generaliserende, anonieme, nomologische karakter van de natuurwetenschappelijke benadering van het individu bekritiseerd. In de eerste decennia van de twintigste eeuw werd deze aandacht voor de eenheid en de individualiteit van de mens, voor de persoon, geleidelijk sterker. De oriëntatie op de mens als persoon, werd allereerst beschouwd als een verfijning van de individualiserende benadering. Men bleef in eerste instantie binnen het kader van de organicistische geneeskunde. Hoewel men in de reflectie op de geneeskunde het begrip "persoon" op de voorgrond plaatste, werden vanuit medischwetenschappelijk perspectief de persoon en het individuele levende organisme over één kam geschoren.

In latere jaren ziet men evenwel een concept van geneeskunde op de voorgrond treden, dat zich afzet tegen een biologische opvatting van de persoon. De individualiserende benadering binnen de geneeskunde werd expliciet van een extra dimensie voorzien, er werd een onderscheid gemaakt tussen mens en (levende) natuur. Denkbeelden over de eigen aard van de mens, in contrast met het organisme, vonden gehoor binnen de medische wetenschap. Het onderwerp van de geneeskunde werd niet langer aangeduid als het zieke organisme, het werd gepreciseerd als de zieke mens. Ziek zijn werd niet langer in biologische termen gevat, het werd in verband gebracht met een specifiek menselijke bestaanswijze. Deze herformulering rechtvaardigt dat we kunnen spreken van een 'antropologische' geneeskunde (vgl. Verwey, 1984, p. 50).

In de antropologische geneeskunde vestigde men nadrukkelijk de aandacht op de concrete zieke. Men analyseerde de medische praktijk teneinde inzicht te krijgen in de filosofisch getinte vraag, wat geneeskunde nu eigenlijk is. Deze overwegingen leidden ertoe dat de antropologisch geneeskundigen zich niet exclusief op één bepaalde wenselijke vorm van wetenschap vastlegden. In het kader van de beoefening van de geneeskunde trachten zij de levensgeschiedenis van de patiënt te reconstrueren. Daarbij zijn allerlei factoren, sociale, psychische en biologische, van belang. In de arts-patiênt relatie werden talloze aspecten van mens-zijn de moeite van het bestuderen waard geacht. Deze werden gewogen in 
het kader van hun betekenis voor de zieke mens. Het begrijpen van de zieke vormde het overkoepelende kader, waarbinnen de verschillende gegevens werden opgenomen.

De antropologisch georiënteerde herformulering van de status van de geneeskunde heeft vooral invloed gehad op het continent van West-Europa. De levenswetenschappelijke definitie van de geneeskunde werd ook daar echter niet volledig verdrongen. De organicistische optiek heeft in de Angelsaksische landen, onder andere geinspireerd door de fysioloog W. B. Cannon (1871-1945) en diens boek The wisdom of the body uit 1932, langer stand gehouden. Een doorwerking van dit wetenschapsconcept ziet men de laatste decennia in de systeemtheoretische interpretatie van geneeskunde (vgl. o.a. Verwey. 1986).

In de kritiek op de objectiverende, generaliserende natuur- of levenswetenschappelijke conceptie van geneeskunde waren theologische en filosofische motieven verweven. Verwey geeft aan dat bij de verschuiving in het zelfbegrip van de geneeskunde, die de antropologische geneeskunde heeft teweeggebracht, religieuze overwegingen van fundamenteel belang zijn geweest (Verwey, 1984, p. 48). Theologen als K. Barth (1886-1968) en H. Ehrenberg (1883-1958) hebben door hun intensieve contacten met de voormannen van de antropologische geneeskunde R. Siebeck (1883-1965) en V. von Weizsăcker (1886-1957), hun stempel gedrukt op het denken over de grondslagen van de geneeskunde (vgl. o.a. Baier, 1988; Ehrenberg, 1956, pp. 7-20).

Ontwikkelingen in de filosofie vonden eveneens expliciet hun weerklank in de antropologische geneeskunde. Er ontstond in die jaren een onmiskenbaar sterke wisselwerking tussen filosofie en geneeskunde. IJveraars voor een antropologisch concept van geneeskunde zochten niet alleen aanknopingspunten in de geschiedenis van de filosofie, met name bij de Romantische filosofen (vgl. o.a. Kasanmoentalib, 1989, p. 237). Zij sloten in hun, telkens uitvoerig beargumenteerde, wijsgerige stellingnamen ook aan bij de toentertijd actuele ontwikkelingen in de Duitse en Franse filosofie.

Aan het eind van de jaren twintig kreeg de wijsgerige antropologie als filosofische stroming vorm. In 1928 verschenen Die Stellung des Menschen im Kosmos van M. Scheler (1874-1928) en Die Stufen des Organischen und der Mensch van H. Plessner (18921985 ). Beide filosofen worden beschouwd als inspirator van de antropologische geneeskunde. Vooral Scheler werd door medici herhaaldelijk geciteerd. In de bloeiperiode van de antropologische oriëntatie in de geneeskunde raakten binnen de filosofie de existentie-filosofie en later het existentialisme in zwang. Ook hier was sprake van een nauw contact tussen filosofen en medici. Jaspers' existentiefilosofie werd, waarschijnlijk mede omdat hij arts was, uitdrukkelijk in de reflectie op de geneeskunde betrokken. Dit geldt ook voor de ideeën van M. Merleau-Ponty, die bijvoorbeeld van invloed waren op de visie van de bekende Nederlandse voorvechter van de antropologische oriëntatie in de geneeskunde, F.J.J. Buytendijk (1887-1974) (vgl. Dekkers, 1985, o.a. p. 153). 
De Joodse dialogische traditie in de filosofie vond eveneens weerklank bij de reflectie op de uitgangspunten van de geneeskunde. Vooraanstaande denkers als F. Rosenzweig (1886-1929) en M. Buber (1878-1965), die expliciet aandacht besteedden aan de arts-patiênt relatie, hadden contact met de pleitbezorgers van de antropologische geneeskunde (vgl. o.a. Theunissen, 1977, p. 254). Zoals uit de dagboeken van Rosenzweig blijkt, kende hij Von Weizsācker al sinds zijn studietijd. Hij volgde rond 1906 te Freiburg colleges in de geneeskunde en ontmoette daar Von Weizsäcker, met wie hij bevriend raakte (vgl. Rosenzweig, 1979. pp. 60-61). De arts Richard Koch, wiens ideeën in het vervolg gesitueerd worden in het overgangsgebied van organicistische naar antropologische geneeskunde, was eveneens goed bevriend met Rosenzweig. Hij was betrokken bij het Frankfurtse "leerhuis", een voor iedereen toegankelijke instelling die een brede vorming beoogde, op basis van de joodse traditie. Aan dit leerhuis was ook Buber verbonden (Op 't Root, 1984, pp. 58 e.v.). De redactie van het voor de opkomst van de antropologische geneeskunde relevante tijdschrift Die Kreatur, dat verscheen in de jaren 1926 tot 1930 , werd gevormd door de filosoof M. Buber, de theoloog J. Wittig (1879-1949) en Von Weizsäcker, een jood, een katholiek en een protestant zoals zij zich zelf afficheerden. In dit blad trad de inspiratie vanuit filosofie en geloof voor artsen, zoals Von Weizsăcker, duidelijk aan de dag (vgl. Buber, 1956, pp. 5-6; Von Weizsäcker, 1926, 1975 (1927), 1980a (1927/1928)). Kortom, zoals de levenswetenschappelijke geneeskunde vorm kreeg in een tijdperk waarin het vitalisme populair werd, zo groeide de antropologische geneeskunde in een tijdperk waarin de wijsgerige mensopvatting van belang werd geacht. Vanuit verschillende achtergronden richtte men zich op de uitwerking van de centrale concepten in de antropologische geneeskunde: persoon(lijkheid). mens-zijn/existentie en zin. Dit bracht met zich mee dat men niet altijd hetzelfde op het oog had in het gebruik van het woord "persoon". Dat de interpretaties en referentiekaders uiteenliepen, verhinderde echter niet dat de relevantie van het concept persoon binnen de geneeskunde allerwegen, zij het soms op eclectische wijze, werd onderschreven. Ten tijde van de organicistische oriêntatie bestond er eveneens een dergelijke eensgezindheid. Zelfs als men geen vitalist was, achtte men toentertijd toch "de eigen aard van de levende natuur" van buitengewoon belang voor de geneeskunde. In de periode van de antropologische geneeskunde was op vergelijkbare wijze "de persoon" het sleutelwoord.

De persoon werd in de antropologische geneeskunde, evenals in de levenswetenschappelijke, gezien als een geheel, als "Ganzheit". De tegenstelling tussen beide concepten van geneeskunde heeft betrekking op de invulling van deze totaliteit. De holistische, levenswetenschappelijke geneeskunde steunde op een biologistisch mensbegrip, de mens als organisme. In de antropologische geneeskunde werd daarentegen aandacht gevraagd voor een principieel niet te objectiveren kern van de mens, aangeduid als persoon, persoonlijkheid of existentie. Met de stap van organisme naar persoon werd de biologische dimensie overschreden. 
De overgang van een levenswetenschappelijke naar een antropologische conceptie van de persoon als middelpunt van aandacht binnen de geneeskunde zal hier worden geschetst aan de hand van het werk van enkele belangrijke Duitstalige auteurs, met name Th. Brugsch (1878-1963) en L. (von) Krehl en zijdelings Fr. Kraus. Brugsch heeft zich vele jaren ingezet voor de bezinning op het medische wetenschapsconcept. Aan het begin van de jaren dertig organiseerde hij congressen met deelnemers uit heel Europa, over de fundering van holistische vormen van geneeskunde. Brugsch en Kraus worden alom beschouwd als wegbereiders van de antropologische geneeskunde.

In zijn Allgemeine Prognostik oder die Lehre von der ärttlichen Beurteilung des gesunden und kranken Menschen van 1918 presenteerde Brugsch een methodiek van de prognose, dat wil zeggen van de leer van de beoordeling van het individu in gezonde en zieke omstandigheden. Dit onderdeel van de geneeskunde was zijns inziens altijd een stiefkind gebleven bij de reflectie op de geneeskunde. Brugsch' boek bestond uit drie delen: het eerste deel was getiteld Habitus und Organisation, het tweede Konstitution en het derde Person. De eerste twee delen legden het fundament voor het uiteindelijke doel: "Jede Person muß, wenn man sie beurteilen will, nach ihrer Personalität (d.i. personale Körperlichkeit) beurteilt werden (...)" (Brugsch, 1918. p. 5-6). Het is voor de arts noodzakelijk om de constitutionele betekenis van de verschillende ziekmakende factoren bij een patiënt op individueel niveau te evalueren. Brugsch betoonde zich enerzijds geïnspireerd door het werk van de eerdergenoemde energetici Martius en Hueppe. In zijn prognostiek presenteerde hij formules waarmee hij in het algemeen het functioneren van het "vitale systeem" weergeeft. Leven, ziekte en dood zijn specifieke waarden van de dynamische functie. Het menselijk leven wordt hier door Brugsch talloze keren gelijkgesteld aan het functioneren van een materieel systeem of van een organisme.

Anderzijds luidde Brugsch' uitgangspunt: “Der Mensch als Individuum ist naturgeschichtlich definiert ein Einzelexemplar der Gattung Mensch, medizinisch erfaßt aber Person" (Brugsch, 1918. p. 365). Daarbij tekende hij echter onmiddellijk aan: "Soll diese Person medizinisch beurteilt werden, so muß sie, wie wir es durchzuführen versucht haben, organisatorisch stigmatisiert und konstitutionell beurteilt werden" (ibid.). De beoordeling van de persoon aan de hand van diens persoonlijkheid en lichamelijkheid, mondde uit in de opsomming van een aantal organicistische aandachtspunten zoals erfelijkheid, aanpassingsvermogen, resistentie en bevattelijkheid. Opmerkelijk is dus dat Brugsch, ondanks zijn antropologisch getinte terminologie, binnen het kader van de organicistische opvatting van de geneeskunde bleef. De voor antropologische geneeskundigen kenmerkende gedachte dat personen en individuele organismen op wijsgerige gronden niet op één lijn gesteld kunnen worden, wordt in 1918 bij Brugsch niet aangetroffen. 
In de door Brugsch tezamen met F.H. Lewy geredigeerde bundel Die Biologie der Person uit 1926 kan men dezelfde tweeslachtigheid vinden. De redacteurs constateerden dat de geneeskunde zich van de biologische beschouwingswijze had bevrijd en dat het onderzoeksveld was uitgebreid tot de persoon als psychofysieke eenheid. Zij verklaarden ervan overtuigd te zijn: " (..) daß der führende Gedanke in der Medizin die Lehre von der gesunden und der kranken Person sein muB" (Brugsch \& Lewy, 1926, p. VI). Constitutie heeft volgens Brugsch sinds enkele jaren afgedaan als sleutelbegrip in de geneeskunde. Het gaat daar niet langer om een meta-individuele constitutieleer, maar om een "Personallehre", een persoonlijkheidsleer. De eenheid, totaliteit en eenmaligheid van de persoon vormen de kern van een geneeskunde waarvoor geldt: "Die Personallehre ist nicht ein Zweig der Nosologie, sondern die Nosologie ist ein Zweig der Personallehre" (Brugsch, 1926, p. 22). De uitwerking van deze opvatting verraadde evenwel dezelfde levenswetenschappelijke tendens als zijn bovengeciteerde boek, zoals blijkt in het vervolg: "Wir müssen ja von einem Menschen wissen, wenn wir ihn ärztlich richtig beurteilen wollen, wie sein Habitus, seine innere Organisation ist, wie seine Entwicklungskurve läuft oder gelaufen ist, wie die Reaktionsnorm beschaffen ist, nicht nur physisch, sondern auch psycho-physisch, und uns kann seine Erblichkeit interessieren" (ibid.). Personen zijn dus individuen met bepaalde unieke scores op curves en andere statistische maten. Een zieke werd door Brugsch enerzijds persoon genoemd, maar anderzijds bestempeld als een individu wiens functioneren niet overeenkomt met de norm. De arts behoorde zich te richten op persoonsgebonden eenmalige afwijkingen op het gebied van vorm en functie, op anatomische en fysiologische gegevens. Dat zieken als personen (mede)mensen zijn had vooralsnog geen specifieke implicaties voor de wetenschappelijke conceptualisering.

Kraus' boek Allgemeine und spezielle Pathologie der Person. Klinische Syziologie uit 1919 is wel aangemerkt als vertrekpunt voor de opkomst van de antropologische beweging (o.a. Keppel Hesselink, 1983, pp. 369-370). Brugsch roemde het als keerpunt, als het boek dat: "(...) die Lehre von der Person für die Gesamtmedizin in den Vordergrund rückte" (Brugsch, 1926, p. 20). In dit boek werden de eigenaardigheden van de persoon geheel geduid in levenswetenschappelijke termen, als specifieke kenmerken van organismen. De term "persoon" werd wel gebezigd, maar diende niet als een aanduiding van de specifieke kenmerken van mensen tegenover andere individuele organismen. De mens werd als één samenhangend geheel, inclusief psycho-fysieke correlaties, onderworpen aan een fysiologische benaderingswijze. Persoon en organisme werden in deze conceptie van geneeskunde uitdrukkelijk op één lijn gesteld, ze werden gelijkelijk bestudeerd als natuurobject. Daarnaast stelde Kraus dat met de biologische bepaling van ziekte, het concept ziekte niet is uitgeput; ziekten worden doorleefd. Persoon en organisme zijn niet identiek. Maar deze constatering heeft bij Kraus, net zomin als bij de 
andere organicistisch georiënteerde artsen van zijn tijd, consequenties voor zijn wetenschapsconcept. Hij hield vast aan de levenswetenschappelijke principes. Binnen de het kader van de medische wetenschap werd de persoon gereduceerd tot organisme.

Kenmerkend voor de verschuivingen in het wetenschapsconcept in de geneeskunde aan het begin van de twintigste eeuw is het werk van de eerdergenoemde internist Krehl, de grondlegger van de antropologisch georiēnteerde Heidelberger School. Van 1898 tot in de jaren dertig publiceerde hij - deels tezamen met Marchand - in totaal 13 drukken van zijn handboek Pathologische Physiologie. Terwijl de eerste drukken vooral het levenswetenschappelijke wetenschapsideaal weerspiegelden, werd allengs het belang van de persoonlijkheid meer beklemtoond (vgl. Siebeck, 1931 b, p. 2169 e.v.; Burkhardt, 1972, pp. 47 e.v.). In de negende druk in 1918 trad deze overgang duidelijk aan het licht: "Wir mūssen berücksichtigen, daß krank nur der einzelne Mensch, die einzelne Persőnlichkeit ist" (Krehl, 1918, p. 2; vgl. Burckhardt, 1972, p. 47). Aan de opvatting dat de zieke mens als persoonlijkheid het onderwerp vormt van de geneeskunde verbond Krehl de gedachte dat de geneeskunde een specifiek soort kennis is. Maar de omschrijving van dit wetenschapsconcept ontbrak voorlopig (vgl. Burckhardt, 1972, p. 49).

Het bovenstaande illustreert dat tot in de jaren twintig de aanzetten tot persoonsgerichte opvattingen van geneeskunde voornamelijk steunden op een levenswetenschappelijk fundament. Voorzover men zich bezon op de persoon als persoonlijkheid stelde men, evenals de bovenbeschreven levenswetenschappelijk georiënteerde artsen, dat deze dimensie buiten het gezichtsveld der wetenschapsbeoefenaars valt (vgl. Haldane, 1923). Aan het concept "persoon" werd nog niet de specifieke betekenis gehecht, die het in de latere antropologische geneeskunde zou krijgen en die aan de hand van het latere werk van Krehl, O. Schwarz (1883-1949), Siebeck en Von Weizsäcker zullen worden geschetst.

In 1928 hield Krehl een voordracht te Leipzig, getiteld Krankheitsform und Persönlichkeit (Krehl, 1929 (1928)). Hij gebruikt hier de term "persoonlijkheid" als de aanduiding voor de mens als een psycho-fysieke eenheid. Dit begrip kon zijns inziens niet langer uit het medische onderzoeksperspectief worden verbannen. Het was enerzijds van belang binnen de geneeskunde, omdat het concept "persoonlijkheid" ook lichamelijke aspecten omvat. Anderzijds hebben psychische factoren als het bewuste en het onbewuste, invloed op de persoonlijkheid en daarmee op de ziekte. Elk mens vertoont volgens Krehl een eigen ziektebeeld, dat in hoge mate afhangt van zijn lichamelijke en psychische persoonlijkheid (vgl. Krehl, 1929 (1928), p. 24). De karakteristieke wijze waarop de zieke zijn ziekte vertoont laat zich dan ook niet simpelweg in schematische verbanden vastleggen. 
In deze lezing beschreef Krehl de voortgang van de geneeskunde, die hij als volgt karakteriseerde: "Die Weiterbildung liegt, soviel ich sehe, in dem Eintritt der Persönlichkeit als Forschungs- und Wertungsobjekt in der Medizin. Das aber bedeutet die Wiedereinsetzung der Geisterwissenschaftan und der Beziehungen des ganzen Lebens als andere und mit der Naturwissenschaft gleichberechtigte Grundlage der Medizin" (Krehl, 1929 (1928), p. 6). Doordat de persoonlijkheid belangrijker werd kon de natuurwetenschap niet meer het exclusieve fundament vormen waarop de beoefening van de geneeskunde berust. Deze ontwikkeling impliceerde volgens Krehl dat wat gewoonlijk als het irrationele of het intuitieve wordt bestempeld, binnen het onderzoek wordt opgenomen. Dat geldt bijvoorbeeld voor inzicht in individuele ziektegevallen, dat zich doordat het wordt geduid als intuïtie lijkt te onttrekken aan de rede. Maar dergelijke vormen van irrationaliteit en intuïtie zijn niet zo ongrijpbaar als men vaak veronderstelt, aldus Krehl. Hij was van mening dat het concept intuitie binnen de geneeskunde gepermitteerd is en dat het niet een tegenstelling hoeft te vormen met het wetenschappelijk verantwoorde denken.

De dertiende druk van Krehls handboek Pathologische Physiologie. Entstehung, Erkennung und Behandlung innerer Krankheiten, dat in drie delen verscheen in achtereenvolgens 1930, 1931 en 1933, wordt algemeen beschouwd als een mijlpaal in de formulering van het antropologisch georiênteerde wetenschapsconcept. In het voorwoord van het eerste deel, Die Entstehung innerer Krankheiten, legde Krehl uit waarom hij zich in zijn boek beperkt tot ziekteverschijnselen bij de mens. Hij noemde daarbij twee redenen, die typerend zijn voor de overgangsperiode van een levenswetenschappelijke naar een antropologische geneeskunde. Ten eerste stelde hij dat ziekteverschijnselen bij de mens zo buitengewoon complex zijn, dat ze niet tot de vaak al te simpele en kunstmatige resultaten van dierproeven zijn te reduceren. Zonder de experimentele pathologie volledig af te zweren, achtte Krehl deze te beperkt. De tweede, voor de antropologische oriēntatie meer kenmerkende en aan de praktijk refererende, reden luidde: "Ich bin Arzt, und für den Arzt ist der Mensch alles" (Krehl, 1930, p.VII). De mens als geheel is voor de arts hét onderwerp van studie. Dat betekende volgens Krehl, dat zowel natuurwetenschappelijk als biologisch en geesteswetenschappelijk onderzoek op hun plaats zijn. Maar hij waarschuwde ervoor te menen dat daarmee de mens als onderzoeksobject op toereikende wijze zou zijn beschreven. "Das Problem des kranken Menschen erschöpft sich nicht in objektiver Betrachtung" (Krehl, 1930, p. VII). Krehls argument om te pleiten voor de erkenning van het belang van het begrip persoonlijkheid bínnen de geneeskunde, was dat de mens zich onderscheidt van de overige levende wezens doordat hij zelf gestalte geeft aan zijn ziekte. De te bestuderen verschijnselen en de vergaarde kennis bezitten daardoor een bijzonder karakter. Er is een cruciaal verschil tussen de studie van de zieke mens en die van de overige levende wezens. Arts en de zieke maken immers deel uit van 
dezelfde menselijke wereld. Zieke mensen zijn derhalve niet alleen een object, ze zijn tegelijk ook subject. Ze reageren op de onderzoeker en ze geven zelf vorm aan hun ziekteverschijnselen.

Het levenswetenschappelijke concept van de geneeskunde werd verlaten, toen Krehl aandacht vroeg voor de actieve manier waarop de mens omgaat met zijn ziekte. Hij liet zien dat het onderzoeksobject van de geneeskunde radicaal verschilt van dat van de biologie. Persoon en persoonlijkheid zijn meer dan termen die slechts aandacht vragen voor het brede scala van mogelijke differentiaties. Voor Krehl gold dat de bepaling van het karakteristiek menselijke, van de mens als persoon, de levenswetenschappelijke reductie onhoudbaar maakte. Niet de complexe patronen van disfuncties maar de zieke (mede)mens vormt bij hem het middelpunt van de aandacht. De studie van de zieke mens tekent zich af als een eigen type wetenschap.

In dit verband is de schets van Krehls visie op de geneeskunde door diens collega F. Müller in 1932 bijzonder illustratief. In een rede ter ere van Krehls zeventigste verjaardag beschreef hij de ontwikkeling van de geneeskunde sinds de jaren tachtig van de negentiende eeuw. Hij toonde hoe Krehl in deze periode telkens opnieuw zijn positie bepaalde. De weg die Krehl had afgelegd vatte hij als volgt bondig samen: "Vom Symptom zur Krankheit und von der Krankheit zum kranken Menschen, zur Persönlichkeit" (F. Müller, 1932, p. 1116).

Krehl is, als leermeester van onder andere Siebeck en Von Weizsäcker en als stichter van de Heidelbergse school, zeer belangrijk geweest voor de ontwikkeling van de antropologische oriëntatie in de geneeskunde. In de periode waarin hij zijn antropologische inzichten ontwikkelde, rond 1930, kan men ook bij andere artsen de contouren van een antropologisch concept van de geneeskunde zien opdoemen. Eén van hen was Schwarz, een privaatdocent urologie te Wenen. Schwarz achtte de tot dan toe gebruikelijke optelsom van benaderingswijzen onverdraaglijk, omdat zo een gedeeld referentiepunt ontbrak. In een moderne geneeskunde kon zo'n basis niet gemist worden: “(...) es wird vielmehr gefordert, von einem weiter rückwärts gelegenen Fluchtpunkt aus das Ganze der sich bietenden Erscheinungen in einem einheitlichen Aspekt zu erfassen und so aus Körperbau, Verhalten und Erleben zu einer wesenhaften Einsicht in das zu studierenden Phänomen zu gelangen. Diese übergreifende Wissenschaft nennt man medizinische Anthropologie. Das zentrale Phänomen der Anthropologie ist die Handlung, die einen Zweck, einen Sinn hat" (Schwarz, 1929, p.1619).

In de door Brugsch in 1933 uitgegeven bundel Einheitsbestrebungen in der Medizin, waarin uiteenlopende vormen van holistische geneeskunde aan de orde kwamen, was ook een bijdrage van Schwarz opgenomen. In dit artikel ging hij dieper in op de aard van zo'n medische antropologie. "Die medizinische Anthropologie registriert und analysiert also alle Erscheinungen am kranken Menschen nicht bloß als einfache Naturtatsachen an einem lebendigen Ding, 
sondern sie sucht sie zu verstehen als Äußerungen der speziellen Existenz eines kranken Menschen" (Schwarz, 1933, p. 87). Hij legde er de nadruk op dat de geneeskunde niet gaat over levende dingen, maar over mensen. Het biologische concept van de geneeskunde verruilde hij derhalve voor een menswetenschappelijke versie.

Schwarz baseerde zijn argumentatie op het bijzondere karakter van de mens. Menselijk leven, existentie, is een dimensie rijker dan het vitale, de levende natuur. Deze dimensie kenschetste hij met het begrip "zin". Menselijk leven bestaat niet alleen uit het verloop van natuurlijke processen, uit een opeenvolging van toestanden die uiteindelijk afloopt. Mensen verkeren in situaties, zij hebben een geschiedenis, zij gaan dood, aldus Schwarz. Het menselijk leven bestaat uit gebeurtenissen die tezamen betekenis hebben. "So hat beispielsweise das Leben schlechthin, wie jeder NaturprozeB, einen 'Ablauf , das menschliche Leben dagegen hat 'Geschichte', d. h. es ist ein Ablauf von Geschehnissen, der aber auch außerdem noch einen Sinn verwirklicht" (ibid.).

Schwarz specificeerde de menselijke bestaanswijze vervolgens als creatief. Mensen verhouden zich tot zichzelf, zij geven vorm aan de omstandigheden waarmee ze worden geconfronteerd. "Das Wesen des Menschlichen besteht darin, daß der Mensch in jedem Augenblicke seiner Existenz zu seinem Leben Stellung nimmt, da $\mathrm{B}$ er niemals blo $\beta$ dahinlebt, als Ding unter Dingen, sondern da $\beta$ er alles, was ihm zustößt 'gestaltet', daß er sich zu sich selbst produktiv verhält" (Schwarz, 1933, p. 88). Deze opvatting van menszijn impliceert dat ook ziekzijn een specifiek menselijk gegeven is, waarin de mens als geheel is betrokken. Niet het organisme, of het menselijk lichaam of de ziel zijn ziek, maar de mens die daarmee in zijn gehele bestaan (Existenz) is getroffen. Ziekte werd in 1925 door Schwarz al als "Leben in der Existenzform der Insuffizienz" gekarakteriseerd (Schwarz, 1925, p. 256). In 1933 omschreef hij het nader als een verstoring van het gestructureerde functioneren, waarbij de functiestoring als een zinvolle reactie op een verstoorde levenssituatie moest worden begrepen (Schwarz, 1933, pp. 9192).

De nieuwe wetenschap die Schwarz voor ogen stond, ging verder dan de biologie. Zij had geen betrekking op het leven zonder meer maar zou gaan over het menselijk leven, over "existentie". Zij zou neutraal staan in de controverse tussen natuur-en geesteswetenschap en zij zou methoden van beide typen wetenschap overnemen. Toch betekende dat niet dat er weer sprake zou zijn van de eerder gewraakte optelsom. Dat kon worden vermeden omdat de "Ganzheitsforschung" het fundament vormde. De antropologische benadering waar Schwarz zich achter schaarde, verschafte een eenheidsvisie; de samenhang werd gesmeed door het specifiek op de mens toegesneden begrip zin. 
In de secundaire literatuur wordt er wel op gewezen dat de "Ganzheitsbetrachtung in der Medizin" en met name de psychosomatische en de antropologische geneeskunde, bijzonder veel aan de Romantiek te danken hebben (o.a. Leibbrand, 1954, p. 410; Kasanmoentalib, 1989). Schwarz baseerde zich in zijn conceptie van menselijk leven inderdaad expliciet op het romantische erfgoed. Zijn opvatting van alomvattende totaliteit ontleende hij aan Von Humboldts begrip "Ganzheit". Dit vertaalde hij als structuur oftewel als een "gestalthaftes Zusammenwirken von Kräften". Een analyse van deze structuur zou, zijns inziens, een antwoord leveren op de vraag naar de betekenis ervan, op de antropologische zinvraag (Schwarz, 1933, pp. 89 e.v.).

Siebeck, de opvolger van Krehl in Heidelberg, wordt wel gezien als de voornaamste voorstander van de "biografische" geneeskunde. In zijn opvatting van geneeskunde stond de levensgeschiedenis van de patiënt centraal. In zijn hoofdwerk Medizin in Bewegung uit 1949 presenteerde Siebeck zijn antropologische conceptie van geneeskunde. De koppeling van natuurobjekt en persoonlijkheid, die zijn leermeester Krehl wezenlijk achtte voor de geneeskunde, werd door Siebeck voltrokken in zijn conceptie van de eenheid van het leven. Een mens is een levende eenheid met een eigen geschiedenis. Essentieel aan de menselijke levensgeschiedenis is niet de opsomming van vaststelbare individuele omstandigheden. In een biografie komen juist de eigen levensstijl, het eigen waarderingspatroon en de visie op het eigen verleden aan bod. Met andere woorden, de biografie is geen scorebord maar een verhaal.

Om een mens, een zieke, te begrijpen dienen we ons te verdiepen in zijn levensgeschiedenis, meende Siebeck. De ziektegeschiedenis van de patiënt is identiek aan diens levensgeschiedenis (vgl. Siebeck, 1949, p. 37). Deze bepaling impliceerde een andere taakstelling van de arts: "Der Arzt muß nicht nur die Vorgeschichte der Krankheit, sondern viel mehr noch Geschichte und Persönlichkeit des Kranken erfassen" (Siebeck, 1949, p. 489). Siebeck hechtte een groot belang aan de anamnese, omdat dit de geëigende weg vormde tot het gewenste inzicht in de levensgeschiedenis van de patiënt. Die anamnese moest dan uiteraard niet het karakter hebben van een registratie van gebeurtenissen of een indeling in bepaalde systematische categorieën, maar formuleerde, als het goed was, de levensgeschiedenis als levensverhaal. Bij elk concreet ziektegeval stond derhalve het unieke subject met zijn eigen verhaal centraal (vgl. Siebeck, 1949, p. 486).

Von Weizsäcker is wel de bekendste pleitbezorger van de antropologische geneeskunde. Evenals Siebeck was hij een leerling van Krehl. Von Weizsäcker was internist; hij bekleedde te Heidelberg de functie van hoogleraar in de neurologie en vervolgens die van hoogleraar in de algemene geneeskunde. 
Von Weizsäcker is vaker gekenschetst als degene die (opnieuw) het subject binnen de geneeskunde heeft ingevoerd. Daarmee bedoelt men dat hij degene is die met klem heeft betoogd dat het essentieel is om het subject te zien in wat men gewoonlijk als het object van de geneeskunde aanduidt. Deze erkenning van het subject achtte Von Weizsacker overigens niet alleen noodzakelijk binnen de geneeskundige praktijk. In elke theorie over het menselijk functioneren diende zijns inziens een vorm van subject-zijn te worden verondersteld. Het subject dat Von Weizsãcker invoerde was niet een autonoom, voor zichzelf doorzichtig, subject zoals bij Descartes. Het is een subject dat is vastgeklonken in de wereld, dat zichzelf telkens moet inzetten om zichzelf te verwezenlijken. Het constitueert zich in de wisselwerking, in de coherentie met zijn object. Subject en object zijn niet te scheiden.

Natuurlijk leeft de mens binnen de fysische wereld, aldus Von Weizsäcker, maar zijn wereld voegt zich niet noodzakelijkerwijs naar fysische dimensies als ruimte, kracht en tijd. De menselijke realiteit is veeleer: " (...) eine beständige Auseinandersetzung von Ich und Umwelt, eine immer erneute Begegnung von Ich und Umwelt, ein flüssiger Umgang von Ich und Umwelt" (Von Weizsācker, 1980 b (1948), p. 100). In het contact met de omgeving, waartoe ook het contact met andere mensen behoort, is telkens weer sprake van nieuwe stellingnames, waarin het subject zichzelf profileert. In de omgang van het subject en de wereld wordt daarom niet iets oorspronkelijks steeds meer zichtbaar. Door het contact krijgt het subject juist vorm. De omgang van subject en wereld wordt niet alleen gekenmerkt door coherentie. Deze kan verscheurd worden, dan is er sprake van een crisis. Het subject wordt in het leven door crises bedreigd. En eigenlijk is het zo, volgens Von Weizsacker, dat het subject pas echt wordt opgemerkt als het dreigt te verdwijnen (vgl. Kasanmoentalib, 1989, pp. 277 e.v.). Deze visie op menselijk functioneren hangt ten nauwste samen met Von Weizsåckers opvatting van geneeskunde. In zijn bepaling van wat geneeskunde inhoudt nam hij duidelijk afstand van de levenswetenschappelijke geneeskunde van de persoon. Dergelijke concepten van geneeskunde achtte hij onbevredigend, omdat niet wordt opgemerkt dat de mens geen object onder de objecten is. De mens is in de levenswetenschappelijke optiek species en geen "persona". De mens blijft een, weliswaar eenmalige, verschijning die men afstandelijk, objectief kan kennen en beoordelen. De persoon die Von Weizsäcker daar tegenover stelde, de drager van het "per-sonare", is degene die de arts aanspreekt. De zieke is een subject dat in nood verkeert, om hulp vraagt en erkenning zoekt. Ziek is niet een objectief vaststelbaar gegeven, volgens Von Weizsâcker, het is iets dat wij ook kunnen zijn. (vgl. Von Weizsäcker, 1975 (1927), p. 218). Arts en patiēnt staan niet tegenover elkaar, maar spreken elkaar aan. In de geneeskunde ontstaat een wisselwerking tussen arts en patiênt, tussen onderzoeker en onderzochte, die van een volledig andere orde is dan de traditionele subject-object relatie. 
Uiteindelijk diende, volgens Von Weizsäcker, een leer van het zieke menselijke functioneren een verhaal te zijn (Von Weizsãcker, 1931, p. 614).

Samenvattend kan gesteld worden dat de antropologische geneeskunde haar uitgangspunt nam in een bepaalde visie op de zijnswijze van de mens, nl. de zieke als "persoon". De filosofische stellingname dat de mens de biologische werkelijkheid te buiten gaat, dat hij in de kern meer en nog wat anders is dan natuur, moest volgens de antropologische geneeskundigen consequenties hebben voor de wetenschappelijke bestudering van de mens (vgl. Verwey, 1984, p. 50). De persoon kan nimmer in inhoudelijke beschrijvingen of in objectieve bepalingen vastgelegd worden. De persoon geeft telkens aan zichzelf gestalte, hij ontplooit zich en ontwikkelt zich voortdurend (vgl. Christian, 1952, p. 121). Daarbij is de relatie met de ander van wezenlijk belang.

Deze zienswijze bracht een andere conceptualisering van ziekte en van het klinisch oordeel met zich mee. Ziekzijn werd gezien als een wijze van menselijk existeren, het is betekenisvol binnen het kader van de levensloop. De ontsluiting van deze betekenis binnen de arts-patiênt relatie was niet de ontsluiering van een al vastliggende situatie. Essentiële aspecten aan de persoon onthullen en ontplooien zich pas in de intermenselijke relatie. De nu volgende bespreking van de antropologische visie op het ziektebegrip en het klinisch oordeel zullen verder bijdragen aan het beeld van deze conceptie van geneeskunde.

\subsection{Het ziektebegrip in de antropologische geneeskunde. De zieke mens}

Bij de reflectie op het ziektebegrip verloor de biologie in het tweede kwart van de twintigste eeuw eveneens terrein als maatgevend wetenschapsconcept. Dat de geneeskunde in toenemende mate steunde op de wijsgerige antropologie kwam hier duidelijk tot uitdrukking. De overschrijding van de tot dan gangbare organicistische concepties, die de biologische dimensie aan de mens tot uitgangspunt namen, trad aan de dag zodra men de mens opvatte als persoon en daar binnen de wetenschap consequenties aan verbond. Deze paragraaf schetst de ontwikkeling van een nieuw ziektebegrip in de antropologische geneeskunde, dat steunde op een dergelijke mensvisie.

Kenmerkend aan de antropologische geneeskunde was, dat ze de praktijk, de concrete situaties waarbinnen geneeskunde betekenis heeft, tot uitgangspunt nam van de reflectie op de geneeskunde. De zieke mens, die in zijn nood de arts om hulp vraagt, werd in de analysen centraal gesteld. Definities en andere abstracte omschrijvingen werden door de aanhangers van de antropologische geneeskunde van secundair belang geacht als men zich bekommerde om een adequate zelfinterpretatie. 
Ten aanzien van het concept ziekte betekende deze stellingname allereerst een verwerping van alle vormen van het ontologisch ziektebegrip. De antropologische geneeskundigen analyseerden het begrip ziekte in zijn alledaagse context. Ziek noemt men diegenen die de arts opzoeken en om behandeling vragen. Een ziekte als abstracte entiteit, een "ens morbi", komt men in de praktijk nooit tegen. Concrete mensen, die zelf contact zoeken met een arts omdat zij zich ziek voelen, wel. Dat mensen zich ziek voelen wordt bepaald door vele factoren. En hetzelfde geldt voor de kwestie of zij erkenning vinden voor hun ziekzijn. Een eenduidig criterium voor het vaststellen van ziekte, zoals de afwijking van bepaalde normen, is in de praktijk niet te geven. In de antropologische conceptie van geneeskunde, die niet zozeer een alternatieve geneeskunde voorstond als wel een beter zelfbegrip van de geneeskunde nastreefde, was daarom de zoektocht naar zo'n vaste maatstaf overbodig. Als richtlijn bij de antropologische georiënteerde reflectie op het ziektebegrip fungeerde de concrete menselijke ervaring van ziekzijn.

Een analyse van de praktijk leerde dat de zieke naar de arts komt om hulp, gemotiveerd door de ervaring van iets onaanvaardbaars. Ziekzijn hoort bij het eigen leven, het draagt een uniek persoonlijk karakter, maar dat maakt het nog niet acceptabel. Zieken voelen zich bedreigd, ziekte betekent een crisis in het bestaan. Antropologisch geneeskundigen hebben enerzijds willen laten zien dat ziekte als menselijke bestaanswijze begrepen dient te worden en niet als een biologische gegevenheid. Ziekte is persoonlijk, betekenisdragend in het licht van iemands leven, ziekte is uniek en concreet. Anderzijds vestigden zij er de aandacht op dat ziekte juist ook de uitdrukking vormt van een breuk, van een verwrongen betekenis.

Een aanzet tot een dergelijke bepaling van ziekte kan men wederom vinden in het werk van Krehl. De eerste drukken van diens handboek Pathologische Physiologie weerspiegelden, zoals hier voor is aangegeven, het levenswetenschappelijke wetenschapsideaal. Maar allengs werd het belang van de persoonlijkheid door Krehl meer beklemtoond. Dit had ook gevolgen voor zijn conceptualisering van ziekte. In 1918, in de negende druk van het handboek, vervolgt hij de in de vorige paragraaf geciteerde passage als volgt: "Krankheiten als solche gibt es nicht. (...), so muß jeder einzelne kranke Mensch als ein besonderes Phänomen betrachtet werden" (Krehl, 1918, p. 2).

In het voorwoord van het eerste deel van de dertiende druk van zijn handboek, Pathologische Physiologie. Die Entstehung innerer Krankheiten, gaf Krehl een toelichting op zijn opvatting van pathologische fysiologie. Hij legde uit dat wat er onder ziekte moet worden verstaan niet eenduidig vast te leggen is. Hij gaf daarom opzettelijk geen echte definitie. Hij schreef: "Dieses Buch wird es schließlich zeigen müssen, was Kranksein ist, denn es soll davon sprichen. (...) Schließlich weiß jeder, der in diesem Buch liest, was Krankheit ist, auch ohne Definition" (Krehl, 1930, p. 2). Een definitie was dus ook niet aan de orde, arts en de zieke maken 
deel uit van eenzelfde menselijke wereld. Evenals Virchow constateerde Krehl dat ziekzijn en gezondzijn niet radicaal verschillen, beide zijn levensprocessen: "Die Vorgänge, die dem Kranksein zugrunde liegen, sind Lebensvorgänge, sie gehören also mit dem, was wir normales Leben zu nennen pflegen, untrennbar, ja ohne jede scharfe Grenze zusammen" (Krehl, 1930, p. 2). De grens die tussen ziek en gezond wordt getrokken, is tijdgebonden, ze berust op de opinie van de betrokkene, op de school waartoe men behoort en op de opvattingen van de wetenschap (vgl. ibid., p. 25). Ziekteverschijnselen zijn uniek, ze dragen het stempel van één persoon, en daarom schieten objectiverende benaderingswijzen tekort, aldus Krehl. Uit de generalisering van de observatie van gelijkende levensprocessen bij zieken, verwerven we wel het begrip "ziekte." Maar dit is een abstractie, zowel ten opzichte van het ziekzijn als gebeuren, als ten opzichte van het eenmalig karakter van ziekten. Wij kennen geen ziekten, alleen zieke mensen, zegt Krehl, en zij zijn als individuele zieken onderling niet gelijk (ibid., p. 24 e.v.).

In 1931, in het eerste hoofdstuk van het tweede deel, Pathologische Physiologie. Die Erkennung innerer Krankheiten, sneed Krehl dit thema weer aan. Een definitie van ziekte gaf hij opnieuw niet. Ziekte is zo'n gecompliceerd proces, dat er al naar gelang de invalshoek weer zo verschillend uitziet, dat hij een dergelijke afbakening maar achterwege liet. Artsen worden geacht zieken te behandelen. Wie die zieken zijn, loopt uiteen. Sommigen zijn verontrust geraakt door ernstige klachten, pijn en functieverlies, anderen hebben last van een kleinigheid en sommigen merken helemaal niets. De arts wordt er dan bij gehaald, aldus Krehl, omdat anderen van mening zijn dat de zieke niet meer is zoals hij was (Krehl, 1931, p. 1).

Zieken verschillen in aanleg, situatie, karakter, uiterlijke omstandigheden enzovoorts. Daarenboven vormen zieken, zoals de levenswetenschappelijke geneeskundigen ook naar voren brachten, als individu een geheel. Dit geheel kreeg bij Krehl een andere betekenis dan bij zijn voorgangers. Zieken zijn een individueel geheel niet alleen omdat hun organische verrichtingen door aanleg en milieu een bepaalde samenhang vertonen, maar omdat zij tot in hun weefsels en cellen een persoonlijkheid zijn. De wisselwerking tussen vorm en functie op organisch niveau verklaart onvoldoende het optreden van ziekten, volgens Krehl. "In das alles mischt sich nun ein die Art und Weise, wie der Organismus aus seelischpersönlichen Gründen sich zu dem Organ- und Körpergeschehen verhält. Es ist gewiß bis zu einem gewissen Grade richtig, daß der menschliche Organismus in seinem Verhalten ein Produkt seiner Umwelt ist. Aber vielmehr noch erfolgt sein Verhalten aus seiner Organisation und ebenso daraus, was Erziehung, Gewohnheit, Sitte und Willen aus ihm machen. (...) Organgeschehen und damit Krankheitsvorgänge können durch unsere Seele und unseren Willen gestaltet werden" (Krehl, 1931 , p. 21). Mensen zijn in staat om zelf als mens aan hun eigen ziekte vorm te geven. Daarom vertoont elke zieke unieke verschijnselen. 
Krehls ideeền vormden als het ware een voorbode van de meer uitgesproken antropologisch gefundeerde geneeskunde uit de jaren dertig tot vijftig van de twintigste eeuw. Siebeck en Von Weizsäcker hebben het gezichtspunt dat de zieke zelf gestalte geeft aan zijn ziekte, verder uitgewerkt in zijn betekenis voor de somatisch gerichte geneeskunde. De zieke mens als persoonlijkheid vormde het centrum van de belangstelling, terwijl de ziekte als disfunctie op de achtergrond raakte. Wezenlijk aan ziekte waren voor de arts niet aantrefbare afwijkingen en andere objectieve gegevens. Men richtte zich in toenemende mate op de betekenis en van de zin van de ziekte voor de concrete persoon.

Siebeck keerde zich in 'Medizin in Bewegung' tegen organicistische en natuurwetenschappelijk geinspireerde omschrijvingen van ziekte. Abstracte overwegingen achtte hij niet relevant voor een beter begrip van ziekte. Met instemming vermeldde hij een uitspraak van Von Weizsäcker, waarin deze de volgende omschrijving gaf van wat ziek/ziekte betekent: " (...) krank ist, wer des Arztes bedarf" (Siebeck, 1949, p. 25). Ziekte is niet iets dat iemand heeft, maar iets dat iemand belectt (vgl. ibid., p. 483). De zieke heeft klachten, hij voelt zich gehinderd en bedreigd. De arts hoort hem aan en constateert bepaalde kenmerken, subjectieve en objectieve symptomen, gestoorde functies en een gewijzigde bouw der organen. Op basis daarvan vormt de arts zich een oordeel. Dit oordeel is niet een zuivere, objectieve vaststelling, een constatering van de feiten, aldus Siebeck. "Krankheit wird vom Kranken empfunden und vom Arzt erkannt oder doch anerkannt" (ibid., p. 24). De grens tussen ziek en gezond laat zich niet op grond van tevoren vaststaande onderscheidingen trekken.

Met zijn afwijzing van de mogelijkheid van algemene maatstaven nam Siebeck stelling tegen elke vorm van een ontologisch ziektebegrip. In zijn conceptie waren ziekten geen reëel bestaande welomlijnde processen. Ziekte is geen kwestie van empirisch te constateren individuele afwijkingen in vorm en functie, zoals we bij de levenswetenschappelijke geneeskundigen zagen. "Es ist Sache des Arztes, sein Urteil über Gesundheit und Krankheit zu fällen, nicht nach diesem oder jenem Begriff, sondern so wie es im Leben geboten ist" (ibid., p. 25). Op dit punt sloot Siebecks visie duidelijk aan bij Krehls eerder genoemde afwijzing van objectieve structuren waarin ziekte te vatten zou zijn.

Het was volgens Siebeck onjuist om te menen dat men kan vaststellen of er al dan niet sprake is van ziekte door onvoldoende weerstand en een gebrekkig aanpassingsvermogen af te meten aan een biologische norm. Iemands prestaties staan altijd in relatie met zijn situatie als mens en moeten vanuit dat perspectief beoordeeld worden. Bij de bepaling van wat als ziek of gezond geldt, zijn de persoonlijkheid van de patiẻnt, zijn levensgeschiedenis en zijn huidige situatie plus het feit dat hij naar de arts is toegekomen, van wezenlijk belang. Ziekte is volstrekt persoonlijk, aldus Siebeck, het is overad en altijd maar de ziekte van één enkele mens (vgl. Rössler, 1959, p. 175). Of de noemer ziek wel of niet van 
toepassing is, wordt mede bepaald door het oordeel van de betrokkene, die blijk geeft van een verandering in zijn zelfperceptie. De biologische norm werd op deze wijze vervangen door een menselijke persoonlijke evaluatie. Ziekte werd in levenshistorisch perspectief geplaatst.

Siebeck identificeerde, zoals gezegd, ziektegeschiedenis met levensgeschiedenis. Het verloop van de ziekte hing zijns inziens niet alleen af van de ziekte als zelfstandig proces, maar heel wezenlijk ook van de levenshouding, de opstelling en de situatie van de patiēnt. Krehls opvatting dat de zieke zelf vormgeeft aan zijn ziekte, werd ook door Siebeck verwoord. Ziekte is niet: " (...) ein willkürlicher Akt, sie ist Schicksal, das der Mensch in sich trăgt und das ihm von außen zukommt. Schicksal aber ist Aufgabe" (Siebeck, 1949, p. 25). Ziekte is niet slechts iets dat de mens overkomt, men geeft er op grond van zijn eigen 'Geschick' gestalte aan. In het licht van iemands leven krijgt de ziekte inhoud maar tezelfdertijd vormt ziekte een integraal onderdeel van het eigen leven. Gezondheid en ziekte zijn betekenisdragend, ze zijn van belang voor iemands bestaan, voor iemands plaats in de maatschappij. Het totale ziekteproces, inclusief alle verwikkelingen, kleurt iemands leven, Siebeck noemde het een "Epoche ins Leben", het laat altijd sporen na. De ziekte treedt op binnen iemands levensloop. en is er op velerlei manier in verworteld.

Von Weizsäckers visie op ziekte verschilde in principe weinig van die van Siebeck. Maar doordat hij er veel uitvoeriger over heeft geschreven, kan een analyse hiervan meer reliëf geven aan beider ideeën, die kenmerkend waren voor de antropologische oriëntatie in de somatisch gerichte geneeskunde in de jaren dertig tot vijftig van de twintigste eeuw.

Bij de rechtvaardiging van zijn antropologisch georiënteerde opvatting van geneeskunde sloot Von Weizsäcker aan bij wijsgerige inzichten die in deze tijd actueel waren. Hij volgde de discussies en ontwikkelingen in de filosofie van nabij, via contacten met onder anderen Scheler, M. Heidegger (1889-1976), Rosenzweig en Buber. Evenals bij Siebeck speelde in Von Weizsäckers pleidooi voor een antropologische geneeskunde het religieuze engagement een rol. In tegenstelling tot Siebeck heeft hij zich tevens uitdrukkelijk laten inspireren door Freuds psychoanalyse. In zijn beschouwingen over concrete ziektegevallen, zoals in Fälle und Probleme en Der kranke Mensch bedient hij zich van dieptepsychologische structuren om inzicht te verkrijgen in de betekenis van de ziekte voor het individu (Von Weizsäcker, 1947b; Von Weizsäcker, 1951).

Evenals Krehl en Siebeck meende Von Weizsäcker dat het onmogelijk was om het begrip "ziekte" in algemene zin te definiëren. Er is niet één vast criterium dat afbakent wat men als ziek dient te bestempelen. Ziekte lijkt in haar ondefinieerbaarheid op begrippen als schoonheid. Het fungeert veeleer als een kader waarbinnen bepaalde definities mogelijk worden. Daarom startte Von Weizsāckers analyse van het begrip ziekte met een verkenning van de medische 
praktijk. "Das wirkliche Wesen des Krankseins ist eine Not und äußert sich als eine Bitte um Hilfe. Ich nenne den krank, der mich als Arzt anruft und in dem ich als Arzt die Not anerkenne" (Von Weizsãcker, 1975 (1927), p. 218).

De enige methode om begrip te krijgen van ziekte is uitgaan van de concrete medische situatie, die een aanvang neemt als een ziekelijk symptoom opvallend wordt. Niets karakteriseert beter het optreden van ziekte dan het waarnemen van een storing, aldus Von Weizsäcker (Von Weizsã cker, 1931, p. 616). De ziekte wordt niet zozeer waargenomen als een defect, er ontbreekt niet iets. Het is veeleer de aanwezigheid van iets anders; er heeft een "Funktionswandel" plaats gehad waarover men bezorgd raakt (vgl. Von Weizsäcker, 1955 (1954), pp. 126128). De zieke raakt ongerust en consulteert de arts. Hij voelt zich niet alleen zwak, hij veronderstelt dat er iets met hem aan de hand is waardoor hij zich hulpbehoevend voelt. Als de patiēnt de hulp van de ander inroept treedt hij terug uit zijn zwakheid, hij objectiveert deze. De zieke richt zich tot de arts, hij zegt "lk ben ziek", en tezelfdertijd brengt hij tot uitdrukking dat er iets men hem aan de hand is (Von Weizsäcker, 1931, p. 616). In ons verzoek om hulp bekennen wij onze nood aan de arts en zoeken wij erkenning voor ons ziekzijn.

De arts heeft de verplichting deze nood te lenigen en moet ervoor waken zich op zijpaden of dwaalsporen te begeven. Hij moet zich realiseren dat deze nood zich op allerlei terreinen kan voordoen en soms kan indruisen tegen bepaalde regels en ordeningen. Von Weizsäcker pleitte ervoor de grenzen van de geneeskunde zo te verleggen dat alle lijden en nood binnen haar sfeer valt. De geneeskunde moest de scheidingen tussen de faculteiten laten wegvallen en zich openstellen voor de fundamentele samenhang in de menselijke nood (vgl. Von Weizsäcker, 1980a (1927/1928), p. 26).

Het onderscheid tussen ziek en gezond was volgens Von Weizsäcker relatief en sociaal bepaald. Sommige omstandigheden worden wel als ziek bestempeld, baren ons wel zorg, maar andere niet. Ons leven lang strijden wij met ziektes, of liever ziekte-achtige omstandigheden. Alleen onze afstomping doet ons ontevredenheid, een dikke buik en een slecht gebit niet als ziek benoemen, terwijl deze slechts gradueel verschillen van de grotere ziektes, aldus Von Weizsäcker (vgl. Von Weizsäcker, 1967 (1956), pp. 8-9). Ziekte is een sociaal gegeven, de zieke zelf behoeft zijn ziekte niet als eerste op te merken, het kan ook door anderen worden waargenomen (Von Weizsăcker, 1947b, p. 63). Daarom vormde de hulpvraag en niet de afwijking van een biologische norm het vertrekpunt van Von Weizsäckers analyse van het concept ziekte.

Evenals de andere antropologisch geneeskundigen huldigde Von Weizsäcker de opvatting dat ziekte betekenis heeft. Ziekte moet niet zozeer worden beschouwd als een individuele reactie op bepaalde omstandigheden, maar als een antwoord op een bepaalde situatie. Als antwoord is ziekte zinvol. Ziekte is niet een willekeurig antwoord op een situatie; ziekte weerspiegelt een conflict dat niet is 
opgelost. Ziekte is vernietigend, omdat het een fout antwoord is. Ziekte maakt duidelijk dat een ander antwoord nodig is (Achilles, 1974, p. 61). Zo verbond Von Weizsäcker gezondheid en ziekte met respectievelijk waarheid en onwaarheid (Von Weizsäcker, 1967 (1956), p. 53).

De betekenis van ziekte is niet onmiddellijk naspeurbaar; in een mensenleven zijn conflicten soms diep verborgen. Bovendien hebben juist niet doorleefde toestanden hun aandeel in ziekte. Von Weizsäcker ging zelfs zover dat hij de uitspraak dat ziekte zin heeft als volgt preciseerde: "(...) nicht aus der vorhergehenden Tatsachen ergibt sich dieser Sinn, sondern aus etwas was nicht Tatsache wurde" (Von Weizsācker, 1967 (1956), p. 250). Bij ziekte zijn zoveel factoren in het spel dat werkelijkheid en onwerkelijkheid door elkaar heen spelen. Een goede analyse van de ziektegeschiedenis mag dan ook niet aan de oppervlakte blijven staan. De arts moet acht slaan op de verhullingen, de verwachtingen, de werkelijkheid én de onwerkelijkheid, opdat het foute karakter van het antwoord aan de dag treedt.

Begrijpt men, zoals Von Weizsäcker deed, de ziekte als een uitdrukking van een onopgelost conflict, dan moet ook de levensgeschiedenis, als toneel waarop dit conflict zich heeft afgespeeld, voor de arts van belang zijn. In Von Weizsäckers talrijke praktijkvoorbeelden blijkt dit duidelijk. Telkens probeerde hij binnen de levensgeschiedenis van de patiënt een aanknopingspunt te vinden voor zo'n verborgen conflict, dat wel zijn invloed doet gelden. In welke sfeer van het menselijk leven zich een dergelijk conflict had voorgedaan, was voor Von Weizsäcker betrekkelijk onbelangrijk. Ziekte kan als representant optreden, fungeert als "Stellvertreter" voor uiteenlopende levensproblemen. Met behulp van de biografische methode moet men de onderliggende transformatie op het spoor zien te komen, om kennis te verkrijgen over de ziekte. Bij de ontcijfering van de betekenis van de ziekte maakte Von Weizsäcker gebruik van de psychoanalytische theorievorming.

Von Weizsäcker verdedigde net als de bovenbesproken antropologische geneeskundigen de stelling dat ziekte altijd persoonlijk is, dat: “(...) jede Krankheit ein kasuistisches Original ist” (Von Weizsäcker, 1967 (1956), p. 240). De originaliteit berust op de manier waarop de ziekte tot uitdrukking komt. Levenscrises als zodanig zijn niet zeldzaam of buitengewoon; in elk leven komen ze voor. Ze oefenen voortdurend hun macht uit, dus ook ingeval van ziekte. (Von Weizsäcker, 1947 b, p. 27). Het eigen karakter krijgen ziekten doordat de zieke zijn ziekte zelf uit. De mens wordt niet alleen getroffen door zijn ziekte, hij geeft er ook vorm aan. Daarom raadde Von Weizsäcker zijn studenten aan om in de praktijk het volgende als richtlijn te hanteren: "Betrachten Sie die organischen Krankheiten versuchsweise immer so, als ob der Kranke seine Krankheit selbst mache" (Von Weizsäcker, 1947b, p. 95). 
De beschrijving van ziekte als een antwoord, als onopgelost conflict en als onwaarheid, als iets dat de mens treft en in het nauw drijft en als iets waardoor de medische interesse wordt gewekt en dat de arts tegelijk moet beschouwen als iets dat de zieke zelf heeft gecreëerd baseerde Von Weizssäcker expliciet op zijn boven beschreven visie op de mens als "subject".

De overgang van de levenswetenschappelijke naar de menswetenschappelijke geneeskunde komt naar voren in de veranderde definitie van het object van de geneeskunde. De individuele patiēnt werd niet langer beschouwd als een exemplaar van een biologische soort, waarvan het functioneren aan een biologisch onderzoek worden onderworpen. De patiënt werd omschreven als persoonlijkheid, als subject. De zieke werd binnen de antropologisch georiênteerde geneeskunde opgevat als een uniek persoon met een eigen geschiedenis.

Ziekten werden binnen deze conceptie van geneeskunde niet opgevat als de levensverschijnselen van een in zijn bestaan bedreigd organisme. Artsen beschouwden niet zozeer het ontdekken van bepaalde disfuncties als hun voornaamste activiteit, doch het helpen van patiënten om de betekenis van ziekten te ontsluiten in een gezamenlijk project. Kenmerkend voor het verschil tussen de antropologische en een niet-antropologische geneeskunde was dat de arts de patiênt zag als medemens, "(...) ziekte, pijn, lijden, sterven van de patiënt zijn voor de antropologisch georiënteerde arts niet louter symptomen van een beschadigd of bedreigd organisme, maar uitdrukking van een wijze van existeren die hij in zijn algemeenheid ook als de zijne erkent" (Verwey, 1984, p. 47). Artsen interpreteerden ziekten als betekenisvolle uitingen, als antwoorden en conflicten. De taak van de arts behelsde de explicatie van de zin van de ziekte, in het licht van de persoonlijkheid van de patiēnt. Doordat de antropologische geneeskundigen de patiënt als subject, als medemens erkenden, traden er in de onderzoeksrelatie verschuivingen op. De visie op het klinisch oordeel werd in dit verband op ingrijpende wijze geherformuleerd. In de volgende paragraaf wordt aandacht geschonken aan de ingrijpende gevolgen die de antropologische oriēntatie binnen de geneeskunde heeft gehad voor de conceptie van het klinisch oordeel.

\subsection{Het klinisch oordeel in de antropologische geneeskunde}

De antropologische oriëntatie in de geneeskunde heeft veel studies voortgebracht over het klinisch oordeel. Het karakter van de arts-patiënt relatie werd onderzocht, evenals de specifieke aard van de diagnose, de prognose en de therapie. Men baseerde zich hierbij op wijsgerige ideeên over intermenselijke relaties en mensenkennis. De concrete situatie, waarin de arts de patiënt treft, werd telkens als uitgangspunt genomen. 
In de vorige twee paragrafen is al aangegeven dat men binnen de antropologische conceptie van de geneeskunde het persoon-zijn van de patiênt beklemtoonde. Patiênten zijn net als alle andere mensen uniek. Zij zijn persoonlijkheden met een eigen geschiedenis. Op basis hiervan hechten zij in hun leven op volstrekt eigen wijze betekenis aan wat er met hen gebeurt. Deze betekenisverlening strekt zich ook uit tot lichamelijk functioneren, een persoonlijkheid is een psycho-fysieke eenheid. Vanuit deze optiek werd ziekzijn gezien als een vorm van menselijk existeren, die wezenlijk verschilt van het eerdere levenswetenschappelijke organische disfunctioneren. Ziekte heeft zin en betekenis binnen de levensloop van de concrete mens. De zin van ziekte was niet in algemeenheden te vatten; de ziekte heeft voor elke persoon een unieke betekenis. In het klinisch oordeel moest de betekenis van ziekte aan het licht treden. Inzicht in de verworteling van de ziektegeschiedenis in de levensgeschiedenis was volgens de aanhangers van de antropologische geneeskunde onmisbaar in het klinisch oordeel. De anamnese nam daarom een belangrijker plaats in. Aandacht voor het historisch perspectief betekende onderzoek naar de wijze waarop de ziekte betekenis kreeg.

Het eerder beschreven levenswetenschappelijk concept van het klinisch oordeel hield eveneens in dat de arts op zoek ging naar de betekenis van ziekte. Een teleologische beschouwing verschafte immers ook een zekere betekenis aan de materiële, op natuurwetenschappelijke wijze verklaarbare processen. Deze werden in relatie gezien met het principe van zelfbehoud. Individuele variaties werden gerelateerd aan verschillen in individuele organisatie en levensomstandigheden. Het finaliteitsprincipe verschafte vervolgens de arts de mogelijkheid om deze factoren in het concrete geval af te wegen en daarover uitspraken te doen. De betekenis van de disfuncties berustte op de mate waarin zij een gevaar vormen voor de instandhouding van het individu.

De teleologische beschouwingswijze creëerde een dimensie waarin de 'zin' van ziekte onderscheiden en vastgesteld kon worden. De arts was in dit geval degene die het oordeel betreffende de betekenis van de ziekte uitsprak. Zijn positie bleef daardoor vergelijkbaar met die van de natuurwetenschappelijk georiënteerde arts, die een materiële stand van zaken constateerde. Het evaluatief aspect, dat door het teleologisch gezichtspunt werd toegevoegd, levert geen principiële wijziging van perspectief op binnen de onderlinge relatie. De patiënt bleef onderzoeksobject, al was het dan het meest complexe object. De arts-patiënt relatie bleef er een van kenner en gekende; ze behield haar objectiverende karakter.

De antropologische oriëntatie binnen de geneeskunde bracht een radicaal andere perceptie van de onderzoeksrelatie met zich mee. Het feit dat de zieke een mens is, werd niet slechts als een complicerende factor gezien bij het verwerven en het toepassen van kennis die de medicus bezit over de levende natuur. Men zag 
de mens als een wezen dat niet alleen onderworpen is aan de omstandigheden maar zichzelf vormt, als een wezen dat betekenis verleent en gestalte geeft aan zijn situatie. Dat impliceerde dat de kennis die men over de mens kon en wilde verwerven een heel ander karakter moest dragen. Volgens de antropologische geneeskunde kon de arts niet van buiten af de betekenis van ziekte duiden. Deze is immers afhankelijk van de persoonlijkheid van de patiënt. Personen kent men op een andere wijze dan objecten, zo stelden de antropologisch geneeskundigen. Daarom wordt er ook iets anders van de arts gevergd dan de toepassing van objectieve generalisaties. Juist in het directe contact tussen arts en zieke wordt de betekenis van ziekte duidelijk. Essentiële delen van de persoon onthullen en ontplooien zich pas in een intermenselijke relatie, in die tussen arts en patiēnt (vgl. Christian, 1952, p. 8). In de antropologische conceptie van geneeskunde was het klinisch oordelen een vorm van mensenkennis. Geneeskunde steunde in dit geval op de verwantschap van arts en patiênt.

De verschuiving van het levenswetenschappelijke naar het antropologische concept van het klinisch oordeel voltrok zich wederom langzaam. De beginfase van dit proces kan geillustreerd worden aan de hand van de geschriften van de eerder genoemde Frankfurtse arts Richard Koch. In 1917 publiceerde Koch een verhandeling over de diagnose (Koch, 1917). In dit boek beschreef hij het verschil tussen geneeskunde en natuurwetenschap. Geneeskunde is geen natuurwetenschap of een ander soort van wetenschap, stelde hij, omdat zij niet primair op kennis uit is. Geneeskunde wil zieken genezen, wil nuttig zijn. Volgens de klassieke aristotelische terminologie is de geneeskunde daarom geen "epistèmè" maar "technè", ze is geen wetenschap maar kunde (Koch, 1917, p. 57). In de geneeskunde maakt men, aldus Koch, net als in de krijgskunde en in de staatkunde, gebruik van het "ganze Wissen der Zeit" (ibid., p. 60). De medische opleiding dient hieraan recht te doen door de student in de praktijk in aanraking te brengen met het leven van zieken (ibid., p. 106-107). Koch sprak ook over de arts-patiēnt relatie. Deze werd door hem enerzijds vergeleken met de manier waarop een man zijn vrouw kent, maar anderzijds ook gekenschetst als de relatie van de arts tot het organisme (ibid., p. 61). Het latere, in de antropologische geneeskunde belangrijke, onderscheid tussen mensen en andere levende wezens werd op dat moment door Koch niet gemaakt.

In 1923 schreef Koch over de grondslagen van de geneeskunde. Wederom stelde hij dat geneeskunde geen wetenschap is, omdat zij niet primair gericht is op kennisverwerving. $\mathrm{Zij}$ berust op een bepaalde relatie tussen mensen, het meest wezenlijke aan de geneeskunde is de arts-patiēnt relatie (Koch, 1923, p.V). Ziekten hebben volgens Koch op verschillende niveaus betekenis, die niet allemaal van belang zijn voor de arts. De arts beperkt zich tot het individuele en het lichamelijke. Uit de praktijk van de geneeskunde volgt: "(..) daß Krankheit, 
soweit sie Reaktion des Kõrpers ist, bedingt zweckmäßig, also sinnvoll ist, daß sie sowohl der Ausdruck des Leben- und Sichwerenkōnnens, als auch der Ausdruck des Leiden- und Sterbenmüssens sei" (Koch, 1923, p. 12). De arts moet in zijn therapie ervoor waken, aldus Koch, dat hij genezen niet gelijkstelt met het bereiken van een statistische norm. Gezondheid heeft te maken met de individuele waardering van de eigen toestand. Artsen slaan vaak te weinig acht op de betekenis van de ziekte. Dan miskent men dat behandeling veelal bestaat uit de verklaring van de betekenis van de ziekte aan de zieke (ibid., pp. 93-94). In dit boek zien we aanzetten tot wat kenmerkend zal worden voor de antropologische geneeskunde. Koch benadrukt dat de intermenselijke relatie van wezenlijk belang is binnen de geneeskunde. Tevens stelde hij dat een verheldering van de betekenis van de ziekte vaak tevens de behandeling uitmaakt. Deze betekenis echter werd door Koch in 1923 op een lijn gesteld met een levenswetenschappelijke categorie als doelmatigheid.

Een verdere uitwerking en formulering van de beginselen van een antropologisch georiênteerde geneeskunde kan men, ook met betrekking tot het klinisch oordeel, aantreffen bij Krehl. In het bovenstaande is al naar voren gekomen dat hij de mens als geheel tot onderwerp van onderzoek bestempelde. Dat had twee consequenties. Ten eerste veranderde het beeld van de arts-patiënt relatie. Het was niet langer adequaat om deze te karakteriseren als een subject-object relatie. De patiënt is niet langer alleen een te kennen object, maar steeds ook een subject dat reageert op de onderzoeker. Ten tweede werd duidelijk dat het onderzoek niet gesubsumeerd kan worden onder de natuurwetenschap, de biologie of de geesteswetenschappen. Het maakt gebruik van deze vormen van wetenschap, steunt er ten dele op, maar het valt er niet mee samen (Krehl, 1930, p. VII).

De problematiek van de zieke mens is niet te vatten in objectieve structuren. De wetenschap van de zieke mens vertoont een eigen karakter; intuïtie en mensenkennis maken er deel van uit. De mens stelt de arts voor andere vragen dan die waarmee de bioloog wordt geconfronteerd, aldus Krehl. "Die Besonderheit und Eigenart jeder Persönlichkeit ist das Hauptproblem. Und es ist die Frage mit der sich jeder Arzt jeden Tag beschäftigt, mit der sich der Kliniker abmüht, denn hier liegt der Vorwurf der Klinik" (Krehl, 1930, p. 30).

Krehl formuleerde dienovereenkomstig de taakstelling van de arts zeer ruim. Als referentiepunt voor zijn analyse koos hij wederom de praktijk, namelijk dat een patiënt de arts om hulp vraagt. Volgens Krehl dient een arts, voorzover zijn capaciteiten reiken en de situatie dit toelaat, de patiënt te helpen bij het nastreven van de hoogste menselijke doeleinden en hem in de daarbij optredende nood terzijde te staan. De opdracht van de arts beschreef hij eerder als: "die Hilfe für einen Menschen durch einen Menschen" en als "die Rettung der Persönlichkeit" (Krehl, 1918, p. 735). 
Binnen dit brede kader onderscheidde Krehl ook een meer specifieke opdracht, die als zijn visie op het klinisch oordeel kan worden gekenschetst. De goede arts poogt, in de woorden van Krehl, om de processen die zich in de zieke afspelen "allseitig kennenzulernen" (Krehl, 1931, p. 14). Daarbij geeft hij er zich rekenschap van, dat deze processen zich bij de individuele patiênt afspelen op twee niveaus die onderling met elkaar interfereren. Enerzijds is dat het niveau van de mens als natuurwezen. Voor deze benadering leveren de pathologische morfologie, de pathologische fysiologie en de psychologie het fundament. Anderzijds is de patiēnt een persoon die zelf gestalte geeft aan zijn ziekte.

Krehl wees erop dat men zich door het feit dat mensen grofweg eenzelfde structuur vertonen, niet moet laten verleiden tot de aanname dat telkens dezelfde symptomen en ziektebeelden zullen optreden. Integendeel, er tekenen zich telkens nieuwe unieke ziektebeelden af. Voor een deel is dit te verklaren als een individuele organische kwestie, aldus Krehl. Constitutie en dispositie drukken hun stempel op de ziekteverschijnselen. Maar de vorm van de ziekte wordt ook bepaald door iemands geschiedenis en persoonlijkheid. "Organgeschehen und damit Krankheitsvorgänge können durch unsere Seele und unsere Wille gestaltet werden. (...) So wie in Organisation oder Erscheinung des Menschen sein ganzes Wesen liegt, wie in ihr das was wir Körper, und das was wir Seele nennen, zu einer Einheit zusammenfließt - wir kennen als Vorwurf der ärztlichen Tätigkeit überhaupt nur diese Einheit -, so drückt sie sich auch bei jedem Menschen in der Gesamtheit seiner Krankheitserscheinungen aus" (Krehl, 1931, pp. 21-23). In de diagnose moest de arts allereerst proberen zich een totaalbeeld te vormen van de zieke, aldus Krehl. Vervolgens onderzoekt hij de orgaansystemen en orgaanfuncties en besteedt hij aandacht aan algemene persoonlijke kenmerken van de patiënt, zoals diens uiterlijk, manier van uitdrukken, houding enzovoorts. De fysieke ziekteverschijnselen en het ziekteverloop worden door schaamte, angst of pessimisme beïnvloed. In het karakter, gevormd door aanleg, opvoeding en gewoonten, vloeien psychische en fysieke eigenschappen van de persoon in elkaar over. Daarom moet de arts ook oog hebben voor de wijze waarop het karakter een stempel drukt op de ziekteverschijnselen. De hulp van de arts steunt op algemene pathologische kennis en op inzicht in de persoonlijkheid van de concrete patiënt (vgl. ook Krehl, 1933, p. 3). In de praktijk leidt dit tot de volgende aanwijzing: "Es gilt im Einzelnen das Allgemeine zu sehen und gleichzeitig zu erkennen, wie das Allgemeine durch das Einzelne geformt wird" (Krehl, 1931, p. 19).

De arts-patiënt relatie werd door Krehl als een persoonlijke, intermenselijke relatie beschouwd. In deze relatie oefenen beiden invloed op elkaar uit, de participanten vormen elkaar (Krehl, 1931, p. 5). Onontbeerlijk voor het klinisch oordeel is dat er contact ontstaat tussen arts en patiënt. In het gesprek met de zieke wordt deze noodzakelijke menselijke verbinding gelegd, doordat de zieke ziet dat men interesse voor hem toont en op zijn wensen ingaat. De arts moet een 
ziekte niet louter vanaf een afstand bekijken, terwijl een zieke er door overweldigd wordt. De arts dient mét de zieke diens ziekte van binnen te schouwen. Pas dan is hij waarlijk arts voor de zieke. Op deze manier is de arts, in Hippocratische zin, een vriend van de zieke.

Krehl beargumenteerde dat het in het kader van de geneeskunde legitiem was om andere vormen van kennis dan alleen de natuurwetenschap toe te laten. Ervan uitgaande dat zieken zowel natuurwezens zijn als concrete personen, schoot zijns inziens de objectiverende verklaringswijze van de natuurwetenschappen tekort. Deze miskent de uniciteit van de patiënt en biedt geen mogelijkheid om de manier waarop mensen gestalte geven aan hun ziekte te begrijpen. Daarom kon en moest de arts, volgens Krehl, in zijn poging de patiênt "allseitig kennenzulernen" een beroep doen op andere vormen van inzicht: "Alles mögliche Geisteswissenschaftliche, alles mögliche ganz Andere, vor allem rein Menschliches, Religiôses, Soziales kommt da hinein" (Krehl, 1931, p. 6). Maar over de vraag hoe deze vormen van kennis tot een samenhangend gezichtspunt kunnen worden geïntegreerd, sprak Krehl niet. Evenmin liet hij zich uit over de consequentíes voor de rationaliteit van het klinisch oordeel als verschillende vormen van kennis, zoals natuurwetenschap, geesteswetenschap en intuïtie worden samengevoegd.

Siebeck ging in dezen een stap verder. In zijn hoofdwerk Medizin in Bewegung uit 1949 gaf hij allereerst een aanduiding van wat hij het fundament acht van elke vorm van geneeskunde. Hij begon met een analyse van wat er onder geneeskunde moet worden verstaan. Geneeskunde was volgens Siebeck het totaal van kennis, dat betrekking heeft op de taak van de arts tegenover de gezonde en zieke mens. Het is een wetenschap die met de tijd verandert, omdat ze gebonden is aan wisselende inzichten omtrent mens en wereld. Maar Siebeck constateerde ook een constante factor: "Die Medizin (...) ist aber zugleich getragen und erfüllt von der in allen Zeiten gleichen Verbundenheit von Mensch zu Mensch, von der immer gleichen Bestimmung des Arztes zu teilnehmender Hilfe in Krankheit und Leiden" (Siebeck, 1949 , p. 1). De geneeskunde werd gefundeerd op de in elke tijd gelijke, onderlinge menselijke verbondenheid.

Siebeck was evenals Krehl de opvatting toegedaan dat de arts een beeld moet krijgen van de patiënt als mens, als psycho-fysiek geheel. Zieken kunnen zins inziens principieel niet tot een organisch, vegetatief systeem worden gereduceerd. Het menselijke vegetatieve systeem is immers tezelfdertijd psychisch en fysieke. Om deze eenheid aan te duiden gebruikte Siebeck de term "stemming" of "gestemdheid". In het dagelijks leven ervaren we in onze gestemdheid hoezeer organische en psychische fenomenen twee kanten van dezelfde medaille zijn. Er is, Siebeck verwees hierbij expliciet naar de visie van Scheler, alleen een begripsmatig onderscheid, het leven is in werkelijkheid ongedeeld (vgl. ibid., p. 12). Bij een verstoring van de stemming kan dan ook nooit slechts één categorie als oorzaak aangewezen worden als oorzaak. 
De stemming, de eenheid van het menselijk leven, kan men bovendien nimmer volledig doorgronden. "In all unserem Fühlen und Wollen, in unserer Stimmung. in Leiden und Leisten wirken sich - uns unbewußt - triebhafte Kräfte aus, die aus Anlage und Lebensgeschichte sich entfalten. Tône aus der ganzen Fülle all unserer Erlebnisse klingen mit; denn nichts, was wir erleben, geht verloren" (Siebeck, 1949, p. 13). Dat betekent evenwel niet dat de arts de patiënt niet zou kunnen begrijpen. De mogelijkheid van het klinisch oordeel berust op het gedeelde leven, aldus Siebeck. De kennis en de erkenning van het ziekzijn, waarbij het inzicht van de arts moet beantwoorden aan de eisen van het leven, worden mogelijk gemaakt doordat de arts en de patiểnt, evenals alle mensen, onder dezelfde hemel leven, uit dezelfde stof zijn gebouwd, van de geboorte tot de dood aan dezelfde wetmatigheden zijn gebonden, op dezelfde wijze door het lot kunnen worden getroffen en op dezelfde deel hebben aan het leven binnen de gemeenschap (vgl. ibid., p. 2 en p. 16). Deze gelijke onderworpenheid aan de lotgevallen van het leven maakt dat de arts, omdat ook hij mens is, op grond van zijn levenservaring kan begrijpen in wat voor situaties de patiênt is geraakt.

Volgens Siebeck bestonden er geen vaste objectieve maatstaven bij het oordelen over ziek en gezond; de arts besluit hierover vanuit het perspectief van het gedeelde leven. "Es ist Sache des Arztes, sein Urteil über Gesundheit und Krankheit zu fallen, nicht nach diesem oder jenem Begriff, sondern so wie es im Leben geboten ist" (ibid., p. 25). In het kader van het klinisch oordeel tracht de arts de visie van de patiēnt op diens ziekzijn te achterhalen. Ziekzijn en klachten hebben is niet hetzelfde; tussen zich lekker voelen en zwaar ziek zijn ligt een scala van onbehagen, waarin elke gradatie van belang is. Deze gradering wordt niet alleen door de materiële schakeringen gekenmerkt. "Jede Stufe (...) ist nicht nur durch den 'Befund' gekennzeichnet, sondern durch die Gesamtverfassung, durch die Einstellung der Person, die es fühlt und davon weiß. Man soll nicht unterschätzen, was das bei der Entstehung und Entwicklung der Krankheit bedeutet, in der psychischen wie in der somatischen Sphäre. Die Persönlichkeit und ihre Situation sind betroffen, und das wirkt sich wiederum wesentlich im Organ aus" (ibid., p. 24).

Voor de diagnose leverde dit als richtlijn op dat de arts via een zorgvuldige anamnese zich een beeld dient te vormen van hoe de patiënt zijn ziekte opvat, wat het voor hem betekent om ziek te zijn, wat voor iemand de patiënt is en hoe hij in de wereld staat. Ook lichamelijk onderzoek is van belang, aldus Siebeck. Functionele stoornissen kunnen in verband staan met organische beschadigingen. Maar de objectiverende onderzoekstechnieken blijven beperkt; ze kunnen alleen worden toegepast binnen het overkoepelende kader van het streven naar kennis van de zieke mens. In de oordeelsvorming staat de concrete zieke en het concrete lijden centraal en niet het verifiëren van bepaalde standen van zaken of het constateren van bepaalde algemene samenhangen. 
De concrete situatie, waarin de patiēnt met zijn klachten naar de arts komt, vormde ook het vertrekpunt in Siebecks eerdere analyses van het klinisch oordeel. Hij wees erop dat in dit proces fysiek onderzoek en aandacht voor de persoonlijkheid van de zieke samengaan. Aan de hand van voorbeelden uit de interne geneeskunde gaf hij aan dat de arts niet kan blijven staan bij de constatering van bepaalde fysieke problemen, er is meer nodig. Bij maagklachten bijvoorbeeld was de conclusie "geprikkelde maag" niet het eindpunt maar juist het beginpunt van de diagnose. Siebecks bedoeling was de "persônlichen Gleichungen" van de zieke te achterhalen. De eigen gewaarwording van de patiēnt, diens persoonlijke inschatting van zijn klachten en zijn totale opstelling, zijn van wezenlijk belang voor het klinisch oordeel (vgl. Siebeck, 1929, pp. 1785-1786). De persoonlijkheid van de patiënt en zijn levensomstandigheden zijn ook essentieel voor de prognose en de therapie, aldus Siebeck. De juiste instelling van de zieke ten opzichte van zijn ziekte, de aanpassing van zijn leven aan de situatie en een juiste alledaagse levenswijze zullen uiteindelijk beslissend zijn voor het verloop (vgl. Siebeck, 1931a, p. 1775).

Met betrekking tot de therapie leidden de bovengenoemde overwegingen tot het standpunt dat de gehele mens moest worden behandeld. "Arztliche Beratung und Behandlung ist Führung" schreef Siebeck (Siebeck, 1949, p. 492). Somatische behandelingswijzen werden al naar gelang de situatie met psychische verbonden. Ook in zijn vroegere voorbeelden schetste Siebeck een behandeling die bestaat uit "Schonung und Beruhigung" en "Umstimmung" op allerlei niveaus. Het therapiedoel was dat er uiteindelijk een juiste instelling werd bereikt. Verschillende therapeutische technieken konden worden ingezet. Maar om daarbij de juiste keuzes te maken moest de arts weet hebben van het levensverhaal van de patiënt, hij moest de patiënt als gesitueerd persoon kennen en verstaan (vgl. Siebeck, 1931a, p. 1775; Siebeck, 1932, p. 1266).

Samenvattend kan gesteld worden dat in Siebecks visie op het klinisch oordeel het begrip van de zieke mens als eenheid, van zijn levensgeschiedenis en van zijn eigen waardering van de ziekte centraal stond. Een arts is door zijn opleiding en zijn ervaring in staat om het karakteristieke van de persoonlijke levensgeschiedenis van de patiënt te vatten. Maar meer fundamenteel geldt, aldus Siebeck, dat de reconstructie van het levensverhaal mensenkennis vergt en dat is een vorm van inzicht die berust op de principiële gelijkheid van onderzoeker en onderzochte.

Voor Von Weizsäcker vormde het verzoek om hulp van een patiënt het uitgangspunt van het medisch handelen, en daarmee ook van het klinisch oordeel. Objectiverend lichamelijk onderzoek als eerste reactie op zo'n hulpvraag werd door Von Weizsäcker afgekeurd. Dat beschouwde hij als een afwending van de eigenlijk nood en een vervalsing van de waarneming van de patiënt. De arts negeerde in zo'n geval dat de patiënt zei "Ik ben ziek" in plaats van "Dit is ziek". 
Volgens Von Weizsäcker diende de uitspraak "Ik ben ziek" een vraag van de arts te ontlokken: "Wat scheelt U?" Dit koppel karakteriseert zijns inziens het ontstaan van de arts-patiênt relatie. Met deze twee al of niet werkelijk uitgesproken - maar minstens veronderstelde - zinnen begint het medisch handelen. Von Weizsäcker hechtte veel belang aan de vraag van de arts omdat daarin tot uitdrukking komt dat hij de patiênt erkent als medemens, als "Du", en hem niet beschouwt als een object, als "Etwas" (vgl. Von Weizsäcker, 1975 (1927), p. 232). Het klinisch oordeel verschilt van het kennen van een toestand. Het is, zoals Von Weizsäcker het uitdrukte, "Menschwissen", mensenkennis, en geen "Sachwissen", feitenkennis. Het begrip van de nood van de ander, die ook een "ik" is, mondt niet uit in een objectief beoordelingsresultaat. In de arts-patiënt relatie is sprake van een wederkerigheid, die de eenzijdige bestempeling van de toestand van de patiênt door de arts als "Een geval van (...)" niet toelaat. "Der 'Sinn der Krankheit' ist nur vom Kranken aus realisierbaar, vom Arzt aus darf er nicht erfordert werden" (Von Weizsăcker, 1980a (1927/1928), p. 30). Overigens benadrukte Von Weizsäcker dat hij hiermee geen pleidooi hield voor de intuitie, doch voor mensenkennis. Intuïtie was zijns inziens niet aan te leren maar mensenkennis, door te oefenen, wel. In dit kader is de grote hoeveelheid ziektegeschiedenissen die hij heeft geboekstaafd, te beschouwen als lesmateriaal.

De verwantschap tussen Von Weizsāckers ideeën en de dialogische filosofie is opvallend. De eerder geciteerde artikelen, "Der Arzt und der Kranke" en "Krankengeschichte" verschenen in de jaren 1927 en 1928 in het tijdschrift Kreatur, waar Von Weizsäcker en de filosoof Buber beiden redacteur van waren. De "mitmenschliche Beziehung', die bij Von Weizsãcker de grondslag vormde van het medisch handelen, gelijkt sterk op Bubers beschrijving van de Ich-Du-relatie. Deze overeenkomst beperkt zich niet tot een gedeelde terminologie.

Bij Buber staat de "Ich-Du"-relatie in contrast met de "Ich-Es"-relatie, de subject-object-relatie waarbij het object afhankelijk is van het subject. De "Ich-Du"relatie is in tegendeel een wederkerige relatie, een ontmoeting. Buber omschreef het verschil als volgt: "Wer Du spricht, hat kein Etwas zum Gegenstand. (...) Aber er steht in der Beziehung" (Buber, 1979 (1923), p. 8). In de "Ich-Es"relatie wordt iets besproken, bekeken, of onderzocht. In de "Ich-Du"-relatie wordt iemand aangesproken en daarmee als gelijkberechtigde partner erkend (vgl. Theunissen, 1977, pp. 283 e.v.).

Von Weizsäcker thematiseerde de kloof tussen een objectiverende en een medemenselijke benadering in de geneeskunde. Omdat ziekte een menselijke zijnswijze, een vorm van existentie is, is de besprekende objectiverende benadering tegenover de patiënt niet van toepassing. Het klinisch oordeel is qualitate qua niet hetzelfde als het oordelen over een object. Het begrijpen van de ziek(t)e moet de inzet vormen van het gesprek tussen arts en patiẻnt. De structuur van de arts-patiënt relatie komt overeen met een dialoog, waarin beide als 
gelijkberechtigde gesprekspartners betrokken zijn op het ziek zijn van de patiēnt en beide als subject worden erkend (vgl. ook Wyss, 1979 (1969), pp. 243 e.v.). Er wordt dus niet óver de zieke gesproken, er wordt mét hem gesproken.

De voornaamste opgave voor de arts was, volgens Von Weizsācker, het begrijpen van de zieke mens. Deze vorm van mensenkennis was niet een onbereikbaar ideaal. In de praktijk bleek dergelijk begrip immers wel degelijk voor te komen. Reflectie op deze vorm van kennis bracht aan het licht dat het in zo'n geval gaat om duiding, om interpretatie, niet om het vaststellen van een bepaalde stand van zaken. Von Weizsäcker was van mening dat: " $(. .$.$) die eigentliche Wahrheit einer$ Krankengeschichte nur erfahren, nicht bewiesen, nur in einer Deutung ausgesprochen, nicht in einer Beobachtung nachgeprüft werden konnte; nicht in der Summe einzelner Beobachtungen oder sie verbindender Kausalurteile ist sie demonstrierbar" (Von Weizsäcker, 1980a (1927/1928), p. 28). Men moet beseffen, aldus Von Weizsäcker, dat menselijke nood ervaren wordt en dat daarbij allerlei dimensies en referentiekaders worden doorsneden. Lijden is niet in één kader te vatten, het gaat eigenlijk alle perken te buiten. Begrip hiervan resulteert daarom niet in de constatering van bepaalde feiten, maar in de formulering van het ervarene als een verhaal.

De arts begrijpt de patiēnt niet op een afstand. De relatie tussen arts en patiềnt impliceert dat de arts mede geïnvolveerd raakt: " (...) er ist ja nur Arzt, wenn er am Patienten krankt, wenn dessen Krankheit sich in ihn fortsetzt und seine Organe mitergreift" (ibid., p. 30). De arts en de patiënt gaan een gesprek met elkaar aan, opdat de crisis die de ziekte uiteindelijk is, op heilzame wijze wordt verwerkt. De biografie van de patiënt is daarbij een belangrijk gegeven. "Weil das Wesen der Krankheit ein biographisches ist, darum kann auch die Erkenntnis der Krankheit immer nur ein biographische sein" (Von Weizsäcker, 1967 (1956), p. 259). Ziekte fungeert immers als "Stellvertreter", dat wil zeggen dat ziekte wordt gemotiveerd en bewerkstelligd door niet-doorleefde conflicten.

Ziekzijn is een dubbelzinnig gebeuren, aldus Von Weizsäcker. Het feit dat iemand ziek is drukt zowel een crisis uit, als ook een zekere aanvaarding. Ook dit gegeven is zijns inziens van belang in het klinisch oordeel. De ziekte moet niet alleen bestreden worden, een zekere erkenning is ook op zijn plaats. Het ontstaan en verloop van ziekte drukt een bepaalde vervulling van een, meestal verborgen, zin uit. Ten eerste moet men tegen de ziekte zeggen "Ja, maar niet zo!" en vervolgens "Indien niet zo, dan anders!" (vgl. Von Weizsäcker, 1955 (1951), pp. 60 61). Ziekte is een crisis, die zowel in vernietiging van het subject als in groei kan uitmonden. Behalve de bedreiging stelt de ziekte een positief resultaat in het vooruitzicht, een toegenomen zelfinzicht. Genezing is niet de terugkeer naar een vroegere gezonde toestand. Het is een overwinning, een overgang naar een nieuw stadium. 
In een intermenselijke relatie is het mogelijk om achter de zin van ziekte te komen. Door de verbondenheid tussen arts en patientnt kan de waarheid naar voren komen. Bij de behandeling van neurosen is dit een geaccepteerd gegeven, aldus Von Weizsäcker. Zijn streven was nu de geneeskunde zozeer te humaniseren, dat men inziet dat dergelijke ideeển niet alleen toepasbaar zijn bij neurosen maar ook bij organische ziekten (vgl. ibid., p. 64). De arts moet zich empathisch opstellen tegenover de patiểnt, vond Von Weizsäcker, hij behoort zich open te stellen voor het wezen van de patiểnt. Om tot een juist begrip te komen, dient de arts zijn eigen opvattingen tussen haakjes te plaatsen. Op dit punt bekritiseerde Von Weizsäcker de aanpak van Krehl. Krehl had weliswaar aandacht voor de zieke als persoon, maar dat kon zich ook uiten in sympathie of antipathie, of zelfs in morele verontwaardiging. Hij ging, naar de mening van Von Weizsäcker, teveel van zichzelf, van zijn eigen maatstaven, uit. Men dient zich daarentegen te oriënteren op de wederkerige relatie, zoals die bekend is uit de praktijk van de psychotherapie. Deze relatie, de "Beteiligung", vormde zijns inziens het fundament van zowel psycho- als somatotherapie.

Von Weizsäcker stelde dat het wel mogelijk is een reconstructie te leveren van het ontstaan van ziekte, maar het toekomstige functioneren kan niet worden voorspeld. Een berekening van het verwachte resultaat op grond van bekende causale samenhangen is principieel onmogelijk. Onze verwachting van wat er zal gaan gebeuren beïnvloedt de afloop van ons handelen. Dat betekent niet dat therapie en genezing een volstrekt toevallige zaak zijn. De arts draagt op grond van zijn ervaring middelen aan om genezing te bewerkstelligen. Dat kunnen medicijnen zijn, autogene training of psychotherapie. Maar het resultaat van deze therapieën is niet eenduidig af te lezen uit de bekende factoren. Genezing is daarom ook altijd een wonder.

Von Weizsãckers opvatting van het klinisch oordeel mondde niet uit in een afwijzing van de wetenschap. In de geneeskunde was zijns inziens wel degelijk plaats voor meer abstracte kennisverwerving en toepassing van wetenschap. Hij gaf in zijn ziektegeschiedenissen telkens voorbeelden van hoe men binnen een arts-patientnt relatie wetenschappelijke kennis en ook psycho-analytische inzichten kan toepassen. Von Weizsäcker, en met hem ook de andere aanhangers van de antropologische geneeskunde, bepleitte geenszins een terugkeer tot een préwetenschappelijke vorm van geneeskunde. Men wees er echter wel op dat ook de wetenschappelijke objectivering van het medisch handelen uiteindelijk berust op een primaire existentiële verbondenheid (vgl. Bräutigam, 1961, p.20). De voorstanders van een antropologische geneeskunde benadrukten dat het klinisch oordeel het begrip van concreet, individueel menselijk lijden behelst. Het was daarom essentieel voor de medische praktijk, dat men de patiënt als persoon ontmoette. De noodzaak hiertoe was geen ethische verplichting, die losstond van een meer technische, objectiverende arts-patiênt relatie. De ontmoeting was 
een noodzakelijke voorwaarde voor het verwerven van een geldig oordeel. De aandacht voor de persoon kwam voort uit het idee dat ziekte zin heeft en dat deze al dan niet verborgen zin van invloed is op het verloop van ziekte. Ziekte is per definitie een persoonlijke, betekenisvolle aangelegenheid. De concrete eenmaligheid daarvan kan niet worden afgeleid uit een specifieke compositie van een aantal factoren, hij berust op het persoon zijn van de zieke mens. In het klinisch oordeel zou deze eigenheid van de patiênt aan het licht moeten treden. Anders voldeed dit oordeel niet aan het gestelde doel: begrip van de zieke mens. In de antropologische geneeskunde was de arts-patiênt relatie, die het karakter droeg van een gesprek, tezelfdertijd onderzoeksrelatie. Hoe kon men nu verantwoorden dat zo'n gesprek specifiek medisch is? Hoe kon de wetenschappelijke scholing van de arts in een wederkerige relatie tot zijn recht komen? De antropologisch georiênteerde artsen verklaarden de intermenselijke relatie tot fundament voor hun medisch handelen. Het gesprek vormde in hun ogen een overkoepelend kader, dat altijd werd voorondersteld in hun professionele activiteit. Binnen het dialogische perspectief achtten zij allen de toepassing van mens- en natuurwetenschappen geoorloofd en zelfs gewenst.

De medische literatuur uit de antropologische stroming bevat opvallend veel casuistiek. De toepassing van medische kennis in concrete gevallen moest worden voorgedaan, zo meende men, het moest aan de hand van voorbeelden worden uitgelegd. In de antropologische visie was klinisch oordelen het uitoefenen van mensenkennis. Mensenkennis verwerft men door oefening en opleiding. door de bestudering van door anderen gevelde oordelen en de reflectie daarop. Casuïstiek was daarom inherent aan de antropologische visie op de geneeskunde.

Aan het begin van de jaren zestig verloor het door de antropologische geneeskunde bepleite zelfbegrip terrein. De nauwe betrekkingen tussen wijsgerige antropologie en geneeskunde werden losser. De criteria waaraan de kwaliteit van de geneeskunde werd afgemeten, verschoven. Critici van de menswetenschappelijke conceptie van de geneeskunde stoorden zich in toenemende mate aan de, naar hun mening, te grote hoeveelheid casus en het te geringe theoretisch wetenschappelijk resultaat. Oudere idealen, die waren verdrongen door de antropologische oriëntatie, bleken opnieuw aantrekkingskracht te bezitten. In de periode waarin de antropologische benadering op haar retour raakte, valt een terugkeer naar meer solide wetenschap, waarin naar regels en algemene wetmatigheden wordt gezocht, te constateren. Natuurwetenschappelijk gefundeerde resultaten legitimeerden een belangrijker positie van deze benaderingswijze in het zelfbeeld van de geneeskunde. Het organicisme, dat ten tijde van de antropologische oriëntatie niet van het toneel verdwenen was maar een eigen ontwikkeling doormaakte, trad naar voren in de gedaante van de systeemtheorie. 
Hoewel de mogelijke relevantie van de systeemtheorie voor de Nederlandse geneeskunde al in de jaren dertig werd gethematiseerd (vgl. o.a. Bruna, 1935), heeft de deze visie op de geneeskunde zichzelf pas sinds de jaren zestig opgeworpen als de opvolger van het antropologische perspectief op de geneeskunde. In de systeemtheorie werden diverse benaderingswijzen verenigd onder één overkoepelend perspectief, dat van het systeem. Dat zou een kader bieden waarin alle mogelijke wetenschappelijke objecten en methoden konden worden ondergebracht. Daarom verzette men zich niet op principiële gronden tegen eerdere visies, maar laakte vooral hun beperkingen. De systeemtheorie pretendeerde de eerder als uiteenlopend beschouwde elementen uit de traditie te kunnen integreren in een totaalbeeld. Het subject, dat de antropologische geneeskunde gepoogd had terug te brengen in de geneeskunde, werd opgenomen in de nieuwere concepties van geneeskunde (vgl. Ten Have, 1987, p. 256). De toepassing van psychotherapeutische principes werd overgenomen in de opkomende multidisciplinaire aanpak (vgl. Thung, 1984, p. 175). Integratie van psychische, fysieke en sociale factoren in het begrijpen van menselijk functioneren werd door de systeemtheorie in een nieuw kader geplaatst. De filosofisch antropologische fundering raakte daarbij op de achtergrond, men claimde vooral wetenschappelijke kwaliteit.

In de systeemtheorie komen elementen uit de tradities die in dit boek besproken zijn, samen; ze worden tot een nieuwe eenheid gesmeed. Dit laat zien dat tradities blijven doorwerken, ook nadat ze openlijk dood zijn verklaard. Wetenschappelijke objectiviteit, het bijzondere karakter van de levende natuur, en het specifiek menselijke blijven binnen de geneeskunde tot de verbeelding spreken. De systeemtheoretische integratie is overigens op haar beurt beperkt. Ook zij levert niet het eindpunt van de discussie over de ontwikkeling van de geneeskunde als wetenschap.

\subsection{Henricus Cornelius Rümke (1893-1967)}

Henricus Cornelius Rümke is geboren te Leiden op 16 januari 1893. Zijn familie telde vele artsen; zijn vader was huisarts en verschillende van zijn broers werden arts. Na het eindexamen gymnasium ging Rümke in 1911 geneeskunde studeren aan de Gemeentelijke Universiteit van Amsterdam. Onderwijs in de psychiatrie, het vak dat Rümke later wilde beoefenen, volgde hij bij K. H. Bouman (1874-1947).

Van 1915 tot 1917 was Rũmke student-assistent in het laboratorium van de fysioloog G. van Rijnberk (1875-1953). Hij ontving vervolgens zijn opleiding tot psychiater bij L. Bouman aan de Valeriuskliniek te Amsterdam; daar bleef hij tot 1928. Rümke voltooide zijn dissertatie Phoenomenologische en klinisch-psychiatrische 
studie over geluksgevol in 1923 onder leiding van L. Bouman. Winkler trad op als promotor, hoewel de benaderingen van L. Bouman en Winkler, zoals hierboven ook is aangegeven, aanmerkelijk verschilden (vgl. o.a. Van Belzen \& Ter Meulen, 1988, pp. 264 e.v.). De reden voor deze constructie was dat het toentertijd onmogelijk was te promoveren bij L. Bouman. De Vrije Universiteit telde toentertijd nog geen medische faculteit.

In de loop van de jaren twintig breidde Rūmke zijn internationale contacten uit. De Valeriuskliniek werd bezocht door bekende buitenlandse sprekers, zoals de filosoof Scheler. Rümke zelf bezocht onder andere de kliniek van P. E. Bleuler (1857-1939) en hij ging in leeranalyse bij A. Maeder (1882-1971).

Van 1928 tot 1933 was Rümke chef de clinique van de psychiatrische afdeling van het Wilhelmina Gasthuis te Amsterdam onder K.H. Bouman. In 1933 werd hij aan de Rijksuniversiteit te Utrecht benoemd als bijzonder hoogleraar in de ontwikkelingspsychologie. Als conservator van de psychiatrische en neurologische universiteitskliniek werkte hij weer onder L. Bouman, die zoals eerder vermeld, in 1925 Winkler als hoogleraar psychiatrie te Utrecht had opgevolgd. Na het overlijden van L. Bouman is diens leerstoel gesplitst in één voor psychiatrie en één voor neurologie. Rümke werd vervolgens in 1937 benoemd tot hoogleraar in de psychiatrie aan de Rijksuniversiteit te Utrecht. Tot zijn emeritaat in 1963, vervulde hij deze leeropdracht en tevens de functie van directeur van de Psychiatrische en Neurologische Kliniek te Utrecht. Na zijn emeritaat bleef hij actief. In 1964 vervulde hij een gasthoogleraarschap in de Verenigde Staten. In 1967 gaf hij gastcolleges te Zürich. Op 22 mei 1967 is Rümke daar overleden. Rümke ontwikkelde zich tot een in binnen- en buitenland bekend psychiater. Deze roem steunde zowel op zijn geschriften als op zijn optreden. Rümke indrukwekkende colleges en patiëntendemonstraties staan vele toenmalige studenten nu nog helder voor de geest. Hij vervulde verschillende functies in nationale en internationele organisaties en genootschappen op het gebied van de psychiatrie, de neurologie en de psychologie. In de "World Federation for Mental Health" speelde hij bijvoorbeeld een belangrijke rol. Rümke was ook, als redactielid, actief betrokken bij verschillende tijdschriften, zoals het Maandblad Geestelijke Volksgezondheid. Een aantal van zijn boeken is verscheidene malen bijgewerkt en herdrukt; van zijn lezingen en artikelen zijn verschillende bundelingen verschenen.

Over het werk van Rümke zijn de laatste jaren herhaaldelijk publicaties verschenen, onder andere een proefschrift vergezeld van uitvoerige bibliografische gegevens, van de hand van J.A. van Belzen (o.a. Van Belzen, 1988a; Van Belzen, 1988b;Van Belzen, 1990). Het is hier niet de bedoeling de studies van Van Belzen in nauwkeurigheid en volledigheid te overtreffen. De opzet van deze paragraaf is eenvoudigweg een andere. Van Belzen onderzoekt de centrale motieven in het oeuvre van Rümke, terwijl in deze paragraaf de conceptuele context waarin hij 
werkte voorop gesteld wordt. Rümke's receptie van de in de jaren dertig tot vijftig vigerende antropologische wetenschapsopvatting is hier belangrijk. Rümke was één der meest vooraanstaande Nederlandse hoogleraren in de medische faculteit. Zijn opvattingen zijn in deze studie van belang wegens de invloed die hij heeft gehad op de vorming en het zelfbeeld van de Nederlandse medici. De overeenkomsten met en de nuanceringen en afwijkingen van de antropologisch georiênteerde conceptie van geneeskunde in Rümke's werk vormen hier het centrale thema.

In 1923, in zijn dissertatie, schetste Rümke dat de wetenschappelijke psychiatrie lange tijd bevangen is geweest door aan andere wetenschappen ontleende benaderingswijzen. Deze hadden elk wel vooruitgang gebracht, maar waren niet autologisch maar heterologisch. Met deze termen van A. Kronfeld (1886-1941), naar wiens werk Rümke uitdrukkelijk verwees bij zijn beschrijving van de fenomenologische methode, wil hij aangeven dat deze andere onderzoeksmethoden niet de in de eerste plaats voor de klinische psychiatrie noodzakelijke kennis van het gezonde en zieke psychische opleverden (vgl. Rümke, 1923, p. 1 en p. 9.). En de klinische psychiatrie was voor Rümke, zoals hij tijdens zijn loopbaan bleef beklemtonen, het centrum van de wetenschap psychiatrie; de klinische psychiatrie vormt voor hem de oorsprong en toetssteen van de gehele psychiatrie (vgl. ook Rümke, 1958 (1957), p. 122).

Bij zijn positiebepaling ten opzichte van de ontwikkelingen in de psychiatrie verklaarde Rümke zich verwant met E. Kraepelin (1856-1926). Hij stelde dat hij het principe van diens systematiek zeer goed verdedigbaar acht. Het verwijt dat men in de praktijk weinig nut heeft van Kraepelins nosologische benaderingswijze, de classificatie van ziekte-eenheden, met name voor het opstellen van een prognose of diagnose, behoeft zijns inziens niet te leiden tot een afwijzing van het systeem als zodanig. De problemen zijn volgens Rümke veeleer het gevolg van de grofheid van de psychologie, die met zich meebrengt dat de klinische onderscheidingen niet duidelijk zijn. Kraepelins ideeën waren in sommige opzichten wellicht wat verouderd, bijvoorbeeld op het gebied van de aetiologie, maar het principe erachter achtte Rūmke van essentieel belang voor de klinische psychiatrie (Rümke, 1923, p. 3 e.v.) Overigens is hij Kraepelin altijd blijven verdedigen (vgl. Rümke, 1958 (1957), pp. 119 e.v.; Van Belzen, 1988a, p. 124). Rümke verklaarde zich anderzijds geïnspireerd door het werk van de fenomenologen Jaspers en Scheler. Jaspers' artikel Die Phaenomenologische Forschungsrichtung in der Psychopathologie uit 1912 noemde hij in dit verband baanbrekend (vgl. Rümke, 1923, p.7). Schelers psychologie, geschetst in diens Der Formalismus in der Ethik und die materiale Wertethik uit 1913-1916 noemde hij eveneens van groot belang voor zijn eigen onderzoek (vgl. Rümke, 1923, p. 50). 
De bedoeling van Rümke in zijn dissertatie was, te onderzoeken wat de fenomenologische methode kan betekenen voor de klinische psychiatrie. Zijn veronderstelling daarbij luidde dat deze methode zou kunnen bijdragen aan de klinische psychiatrie die, zoals hierboven is geschetst, tot dan toe mank gaat aan een te grove psychologie en problemen heeft met het opstellen van diagnosen en prognosen. Deze veronderstelling werd geschraagd door zijn stelling dat het geen betoog behoefde dat de fenomenologie grote waarde heeft in zich zelf bij het kenbaar maken van het menselijk zielenleven (vgl. ook Rümke, 1948 (1922), p. 90).

In zijn uitleg van (de bronnen van) de fenomenologische methode verwees Rūmke, parallel aan de bovenstaande schets van de antropologische geneeskunde, naar de filosofie, o.a. naar één der grondleggers van de menswetenschappen W. Dilthey (1833-1911), en naar de Duitse Romantiek (vgl. ook Rümke, 1964 (1929), pp. 31 e.v.). De verdienste van Dilthey was, volgens Rümke, dat dankzij diens inspanningen aan de psychologie voor het eerst het volgende als probleem werd voorgelegd: de wijze hoe de psyche zich zelf en de buitenwereld beleeft (vgl. Rümke, 1923, p. 10). Dit beleven moet op een wetenschappelijk bevredigende wijze worden onderzocht, aldus Rümke. Dan zou er een alternatief worden gevonden voor enerzijds de objectieve experimentele psychologie, die wel wetenschappelijk is maar leidt tot een psychologie zonder psyche, en anderzijds onwetenschappelijk kunstenaarschap en intuitie. De fenomenologie van Jaspers - die volgens Rümke iets geheel anders is dan de fenomenologie in de zin van E. Husserl (1859-1938) - kan in de psychiatrie en de psychologie tot belangrijke wetenschappelijke resultaten leiden Het levert een bijdrage als men tracht te weten: "(...) wat zich in het bewustzijn van gezonden en zieken als 'beleven' afspeelt. Dit is een onderzoek, dat past in het kader van een ervaringswetenschap" (vgl. ibid., pp. 15-16). Rümke verwoordde hiermee een stellingname die verwant is aan de opvattingen van Kronfeld over de toepasbaarheid in de psychiatrie van de fenomenologie van Hussserl en Jaspers (vgl.Verwey, 1990, pp. 698 e.v.). Aan de basis van de fenomenologische methode ligt het invoelen, waarvoor Rümke een aan Th. Lipps (1851-1914) ontleende definitie gaf: "(...) door een niet verder te herleiden instinct geschiedt het, dat in de opvatting der bepaalde zintuiglijk waargenomen feiten en toestanden - die wij dan achteraf als levensuitingen of zintuigelijke verschijning van een ander individu aangeven - onmiddellijk de gedachte aan een levensuiting, een voelen, een willen, enz., zooals ik het vroeger in mij zelf beleefd heb, in mij, den opvattende, zich roert en in mijn tegenwoordig beleven zich indringt, zoodat het in mij met de Akt van de opvatting samen tot één beleving in mijn bewustzijn wordt; daardoor is het voor mijn bewustzijn, ofschoon uit mij zelf stammend, aan het waargenomen en opgevatte zintuigelijke gebonden, kortom, het is daarin geobjectiveerd" (ibid., pp.1718). Door het invoelen, het stellen van vragen en door mededelingen van 
patiënten vormen zich drie categorieên van fenomenen, waarbij onder fenomeen wordt verstaan "wat" en "hoe" iets door een "ik" wordt doorleefd. Dit zijn ten eerste de fenomenen die door iedereen uit eigen beleven worden gekend, ten tweede fenomenen die vergrotingen, verminderingen of vermengingen van zelf beleefde fenomenen zijn en tenslotte fenomenen die niet invoelbaar zijn, zelfs niet door ervaren onderzoekers (vgl. ibid., pp. 12 e.v.).

Rümke erkende dat bij het invoelen een criterium voor de juistheid of onjuistheid van het ingevoelde ontbrak. Maar dit achtte hij geen onoverkomelijk bezwaar. Bij de duiding van zogenaamd objectieve gegevens ontbreekt een dergelijk criterium zeer dikwijls ook. En bovendien wordt onjuist invoelen vaak later door het vervolg gecorrigeerd, aldus Rümke. Tevens wees hij erop dat invoelen en observatie net zo min iets met elkaar te maken hebben als fenomeen en symptoom. Het gaat bij invoelen en fenomenen niet om objectieve gegevens, maar om het belevende ik.

In de zuivere fenomenologie onderzoekt men de afzonderlijke fenomenen. Als men de samenhang tussen opeenvolgende fenomenen wil begrijpen, treedt men daarbuiten en houdt men zich bezig met "verstehende" psychologie, aldus Rümke. Daarin worden de onderlinge relaties vanuit een genetisch standpunt op hun begrijpelijkheid onderzocht. Begrijpen omschreef Rümke in dit kader als: “(...) het zich subjectief kunnen invoelen van den samenhang, met het begeleidend gevoel van evidentie" (ibid., pp. 23-24). Dit gevoel van evidentie heeft in zich zelf overtuigingskracht, het is niet inductief te bewijzen maar steunt op mensenkennis.

Dat wil niet zeggen dat men in een concreet geval geen gebruik maakt van objectieve gegevens, aldus Rümke. "Het oordeel over de werkelijkheid van een begrijpelijke relatie in een bijzonder geval berust niet alleen op de evidentie daarvan, maar ook op het objectieve materiaal van aantoonbare aanknoopingspunten. Dit materiaal kan nooit volkomen zijn. Daardoor bleef elk begrijpen van een speciaal geval min of meer een 'deuten', dat slechts in zeldzame gevallen een relatief hoogen graad van volkomenheid bereikt" (ibid., pp. 24-25). Invoelend begrijpen leidde volgens Rủmke tot de psychologie zelf, "tot het werkelijk weten van menschelijk zieleleven" (vgl. ibid.).

Het invoelen levert een voorname maatstaf op in het klinisch oordelen, aldus Rümke. Bij waanvorming geldt bijvoorbeeld het volgende: "De intentionaliteit is bij iedere waanvorming gestoord, maar hier hebben wij er op te letten, of deze stoornis al dan niet invoelbaar is, waarbij vooral gunstig mag geoordeeld worden bij ontbreken van volslagen oninvoelbare momenten. Men bedenke, dat één volkomen oninvoelbaar beleven opweegt tegen een reeks van invoelbare verschijnselen" (Rümke, 1948 (1922), p. 99). Invoelbaarheid werd gepresenteerd als een criterium voor het pathologische karakter van bepaalde gevoelens 
(vgl. Rümke, 1923, p 143). Met name prognostisch was het zijns inziens waardevol. Een uitkomst van Rümke's dissertatie-onderzoek luidde: "De statische onimvelbaarheid van een geluksdoorleving in em bezonnen toestand blijkt prognostisch ongunstig" (ibid., p. 206). De fenomenologische methode voegde zo een wezenlijk element toe aan de psychiatrie. Men leerde alert te zijn op de mate van invoelbaarheid van de door de zieke beschreven fenomenen. Hoe discutabel en complex invoelen ook moge zijn, het was volgens Rümke van essentieel belang bij de beoordeling van patiênten (vgl. ook Rümke, 1937, pp. 9-11).

Welk belang hechtte Rümke nu aan de fenomenologie? Bij de beantwoording van deze vraag blijkt Rümke's verwantschap met de antropologische conceptie van de geneeskunde. Het perspectief van waaruit Rümke de fenomenologie beoordeelde, was dat van de praktijk. Zijn vraag luidde: Wat levert de fenomenologische methode op voor de klinische psychiatrie, oftewel voor het op de concrete persoon toegespitste klinisch oordeel? Rũmke beschouwde zichzelf niet zozeer als theoretisch geleerde maar veeleer als clinicus. In zijn intreerede in 1933 formuleerde hij het als volgt: "Als kern van mijn wezen, beleef ik mijn dokter-zijn" (Rümke, 1933, p. 29). In zijn volgende intreerede in 1937 bevestigde hij dit nog eens nadrukkelijk, hij voelde zich voor alles dokter (vgl. Rümke, 1937, p. 28). Hij bleef zijn loopbaan lang het belang van de kliniek onderstrepen. De psychiatrische kliniek is, aldus Rümke, het centrum van alle psychiatrische bemoeienis, het forum waar alle nieuwe richtingen en opvattingen op hun waarde getoetst moeten worden (vgl. Rümke, 1948 (1932), p. 26; Rümke, 1958 (1957), p. 122).

Het middelpunt van de klinische psychiatrie is, aldus Rümke: "(...) het probleem, dat de concrete psychisch zieke mensch ons stelt (...)" (Rümke 1948 (1932), p. 18). In lijn hiermee gaf hij de volgende beschrijving van de klinische psychiatrie: "Naar mijn mening [onderzoekt, IWH] de klinische psychiatrie niet de verschijnselen als zoodanig, doch in verband met den concreten biopsychischen persoon; voorts meen ik, dat de ten grondslag liggende processen evenzeer binnen het klinisch psychiatrisch onderzoek vallen voor zoover zij voor het ontstaan der verschijnselen beteekenis hebben" (Rümke 1948 (1932), p. 19). Wat betreft de nadruk op de praktijk en de visie op de waarde van de theorie, die altijd wordt gerelateerd aan de waarde voor het begrip van de individuele zieke, stemmen Rümke's ideeën en de uitgangspunten van de antropologische geneeskunde dus sterk overeen.

Rümke was er niet op uit om de geneeskunde zo te veranderen dat de natuurwetenschappelijke methoden overboord werden gezet ten gunste van de geesteswetenschap. De psychiatrie behoorde zijns inziens door haar object noch uitsluitend tot de natuurwetenschappen noch uitsluitend tot de geesteswetenschappen. De psychiatrie wordt gekenmerkt door een "dubbele bouw", een 
tweeledigheid die aanvaard en niet verdoezeld moet worden (vgl. Rümke, 1937, 13). Hiermee onderscheidde de psychiatrie zich overigens niet principieel van de geneeskunde als geheel (vgl. ibid., p. 5). Voor sommige onderdelen van de psychiatrie is de natuurwetenschappelijke methode de geëigende benaderingswijze. Maar aan de andere kant geldt, volgens Rümke: "De phaenomenologie is de basis van onze kennis van het psychisch leven" (ibid., p. 11). Winklers stelling dat hysterie een organische ziekte is, bevatte volgens Rümke zonder twijfel een deel van de waarheid. Maar als men de hysterie echt wil begrijpen, heeft men hulp nodig van de antropologie, zo stelde hij. Dan moet men erkennen dat hysterie een uitsluitend menselijke ziekte is (vgl. ibid., p. 23). Elders schreef hij: "ledere zielkunde begint met invoelen en zelfkennis" (Rümke, 1964 (1929), p. 35).

De concrete persoon stond voor Rümke in het middelpunt. Bij zijn bespreking van de diagnose en van het klinisch oordeel in het algemeen, beklemtoonde hij dit telkens weer. Diagnoses zijn geen etiketten, maar: “ (...) de werkelijke doorschouwing van het concrete geval (...)" (Rümke, 1937, p. 23). Zoals bij de eerder genoemde antropologische geneeskundigen werd bij het klinisch oordelen geen enkel perspectief bij voorbaat verworpen. De psychiatrie is nu eenmaal geen "einheitliche" wetenschap. Binnen de klinische psychiatrie worden ver-

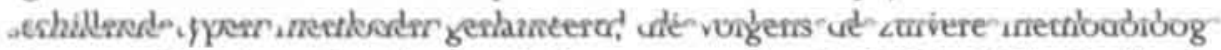
niet met elkaar in verband gebracht kunnen worden. In 1958 zei Rümke dit als volgt: "De clinicus echter, die met een concreet mens in nood te doen heeft, is meestal methodisch meer onbekommerd" (Rümke, 1958b, p. 70). En al geven de goede resultaten hiervan op zich niet de garantie voor de juistheid van deze werkwijze, ze leveren er wel argumenten voor.

Rümke heeft een lijst gegeven van de negen verschillende "betrekkingssystemen", die in de psychiatrie gehanteerd kunnen worden. Ze zijn ontleend aan uiteenlopende theorieẻn en referentiekaders. Het scala varieert van natuurwetenschappen, zoals de fysiologie, anatomie, biochemie en elektrofysiologie, via diverse psychologische en psychiatrische opvattingen, tot de verbondenheid met de kosmos en met het transcendent-metafysisch-religieuze beginsel en de verbondenheid met God (vgl. Rümke, 1958b, p.70). Psychiatrische diagnoses zijn volgens Rümke betrekkelijk. Dat wil zeggen dat bij het stellen van een psychiatrische diagnose, de verklarende condities in alle negen betrekkingssystemen kunnen worden gezocht. Wezenlijk voor een "echte diagnose" is dat de ziekteverschijnselen betrokken gedacht worden op: “(...) bekende of onderstelde grondslagen, die op zichzelf in hun onderlinge samenhang zijn gestoord. (...) Wordt bij de diagnose op deze samenhang geen licht geworpen, dan hebben wij in het geheel niet met een diagnose te maken. Dan hebben wij op zijn hoogst de patiẻnt gerubriceerd. Deze fout moeten wij uit de weg gaan. (...) Het classificeren in een rubriek is zeker niet onbelangrijk. (...) Een doorschouwing van de concrete eenmalige zieke, die hij voor zich heeft, kan hij uit de rubriek niet halen. 
(...) Het individuele gaat dan verloren. (...) De diagnose is de theorie van deze zieke" (Rümke, 1953 (1952).p. 119).

Volgens Rümke diende het wetenschapsconcept dus te beantwoorden aan de klinisch-psychiatrische praktijk en niet omgekeerd. Dat daaruit een beeld oprijst van een wetenschap die volgens methodologen wellicht onmogelijk is, deerde hem niet bijzonder. Menselijke ziekten kunnen nu eenmaal bepaald zijn door uiteenlopende factoren en in de kliniek gaat het om zieke mensen. In zijn gedachten over therapie huldigt Rŭmke dezelfde eclectische houding. De praktijk, het welslagen van de therapie in een concreet geval, vormt zijns inziens ook de maatstaf voor de juistheid van het therapievoorschrift.

Van Belzen wijst erop dat Rümke in de loop der jaren meer lijkt te pleiten voor de natuurwetenschap dan voor de geesteswetenschap (Van Belzen, 1988a, p. 75). Maar Rümke bleef zich verzetten tegen de exclusieve aanspraken op geldigheid van één type wetenschap. In zijn diesrede "Een bloeiende psychiatrie in gevaar" uit 1954 constateerde Rümke dat: " (...) de hedendaagsche psychiatrie opnieuw een sterk philosophischen inslag heeft gekregen" (Rümke, 1954, p. 9). Debet aan deze ontwikkeling zijn de Amerikaanse leer van de "human relations" en "(...) de in Europa opkomende phaenomenologische anthropologie en philosophische anthropologie die door 'schouwen' het wezen der dingen innerlijk ervaart" (ibid.). Rümke stelde dat er een overeenkomst bestaat, ten gevolge van de beïnvloeding door deze filosofische opvattingen, tussen de Amerikaanse en de West-Europese psychiatrie. Deze was daarin gelegen, "dat mensch en wereld met elkaar gegeven zijn" (ibid.). In 1954 was luidde zo, in de visie van Rümke, de kerngedachte van de hedendaagse psychiatrie.

In hetzelfde artikel noemde Rümke vele vertakkingen binnen de psychiatrie die elk op eigen wijze deze "fundamenteele opvatting" naar voren brengen. Daartoe rekende hij bijvoorbeeld C. R. Rogers, met zijn client-centered psychotherapie, maar ook fenomenologen en antropologisch geneeskundigen zoals L. van der Horst, F.J.J. Buijtendijk, J.H. van den Berg, K. Jaspers, L. Binswanger, enzovoorts. Vervolgens noemt hij onder anderen Von Weizsäcker en J. Groen in het kader van de psychosomatische geneeskunde. Er zijn zoveel richtingen en de psychiatrie bloeit zozeer, aldus Rümke, dat zij buiten haar oevers treedt. De grenzen worden te gemakkelijk overschreden. Daardoor raakt de psychiatrie in gevaar (vgl. Rümke, 1954, pp. 9-10).

Rümke beschreef vervolgens de verschillende soorten verzoekingen waaraan de psychiater bloot staat. De eerste was: "De verzoeking de eisch der objectiviteit te laten vallen" (ibid., p.12). Evenals andere artsen moet een psychiater: "(...) de mensch, die zijn hulp zoekt als mensch naderen" (ibid.). Er vindt een "ontmoeting" plaats, de psychiater moet zijn patiënt "subjectief" begrijpen, en daartoe moet hij kennis hebben van de fenomenologie. Maar hij mag niet stil blijven staan bij het "subjectief geschouwde", aldus Rümke. Hij moet dat kunnen overbrengen naar: "(...) een objectief wetenschappelijke beschouwing en zoover het 
maar eenigszins kan het waargenomene relateeren aan wat zijn eigenlijkst terrein behoort te zijn als medicus: de bestudering van biologische functies" (ibid., p.12). Blijven staan bij de subjectief geschouwde werkelijkheid was kwalijk, meende Rümke, omdat de arts dan niet terug keert tot zijn uitgangspunt. Dat uitgangspunt is: "(...) dezen concreten zieken mensch, die niet alleen geest is, maar een wezen van vleesch en bloed, wiens levensfuncties gestoord zijn, die gebonden zijn aan biologische wetmatigheden, aan oneindig gecompliceerde anatomisch te onderzoeken structuren, aan neuro-physiologische regulaties, aan ingewikkelde chemische processen, die gepaard gaan met meetbare electrophysiologische processen (...)" (ibid., pp. 12-13). Door niet terug te keren naar de natuurwetenschappelijke benadering, zou de psychiater zijn patiênt genezingskansen laten ontgaan. Hoewel het te ver kan gaan was objectivering volgens Rümke zeker noodzakelijk.

De psychiater moet zoveel mogelijk betrekkingssystemen kennen en toepassen, meende Rümke. Daarbij hing het vooral van de wereld- en levensvisie van de psychiater af, hoe hij dacht was op de hiërarchie tussen deze verschillende systemen. Niettemin verklaarde hij ook dat, onafhankelijk van alle wereld- en levensvisies, het biologische referentiekader centraal moet staan. Biologische methoden hebben, ook in de psychiatrie de schoonste resultaten opgeleverd, aldus Rümke (vgl. Rūmke, 1954, p. 18). De psychiater is als arts in de eerste plaats een natuurwetenschappelijk onderzoeker, een bioloog, aldus Rũmke. Een totale reductie van de psychiatrie tot biologie wees hij af. Maar hij meende wel dat veel van wat geesteswetenschappelijk is gevonden, via reductie, biologisch zal kunnen worden geïnterpreteerd. Hij heeft zelf overigens geen natuurwetenschappelijk onderzoek verricht (vgl. Rooymans in Rümke, 1981, p. 15).

Psychologie en biologie zijn niet volledig van elkaar gescheiden; de objectgebieden lopen in elkaar over. De fenomenoloog zal ontdekken dat biologische objecten niet voorhanden zijnde dingen zijn, en dat biologen in toenemende mate rekening houden met totaliteit. Juist een recente stroming als de cybernetica, bood volgens Rümke aanknopingspunten. In de psychiatrie dienden zijns inziens andere betrekkingssystemen niet te worden verwaarloosd. "De psychiater heet altijd met den geheele mensch te doen levende onder de zeer bijzondere voorwaarde, door zijn ziek zijn gegeven. Om den mensch te kennen heeft de psychiater de geesteswetenschappen minstens zoo nodig als de natuurwetenschappen, maar om zijn ziekte te behandelen en te begrijpen zal hij dieper en dieper moeten doordringen in de biologie en de pathobiologie. Ik handhaaf mijn in 1937 uitgesproken meening, dat de psychiatrie geestes- én natuurwetenschap is, maar mijn ervaring heeft mij geleerd thans het zwaarste accent te leggen op 'natuurwetenschap' " (Rümke, 1954, p. 19). 
Rümke waarschuwde er ook tegen om de zieke mens naar de inhouden van het beleven te beoordelen. Dat was de tweede verzoeking. Vreemde inhouden boeien ons en het is verleidelijk om te menen dat door de relatie tussen de inhouden de toestand van de zieke te begrijpen zou zijn. Hiertegenover verdedigde Rümke de visie dat er in de pathologie aandacht moet worden besteed aan de vormen van het psychisch leven. "Inderdaad is de eigenaardigheid van psychisch ziek zijn veel eer een kwestie van vorm, van de wijze, waarop deze geestelijke inhoud is "ingebouwd" in het geheel van dezen mensch dan van inhoud" (ibid., p. 14). Bij het begrijpen van de mens ging het hem om de oppervlakte van het geestelijk leven van de mens, dat wil zeggen: "(...) zijn lichamelijke oppervlakte en gestalte en het voor ieder 'zichtbare' van zijn psychische persoonlijkheid, zijn psychomotoriek, zijn stem, de woorden, die hij spreekt, de daden, die hij doet, de liefde die hij geeft of niet geeft, de gevoelens die hij uit of niet uit. (...) De oppervlakte is het meest eigene, de oppervlakte is zijn individueele kenmerk. Wanneer men mij vraagt: wat is de mensch eigenlijk, dan zou ik willen antwoorden: zijn gevormde oppervlakte" (ibid., p. 15).

Rümke maakte verschil tussen gezond en ziek aan de hand van het concept vorm. Het verschil tussen beide is waarschijnlijk een vormprobleem, zo schreef hij (vgl. ibid., p. 16). Het zieke, psychisch gestoorde leven moet niet worden verward met het diepste leven, dat juist de normale mens op suprème momenten beleeft. Mensen zijn ten prooi aan allerlei soorten soms vrijwel ondraaglijke spanningen, die hen diep kunnen treffen. De normale mens weet terug te keren tot een normale bevredigende wijze van leven, en de geesteszieke niet. "Het pathologische mist vormgeving, mist stijl, mist daardoor - wonderlijke paradox - want in het psychisch gestoorde leven zijn spanningen genoeg - spanning, de spanning van gebreidelde hartstocht in subliemen vorm" (ibid.). Een groot deel van de psychische stoornissen ontstaat doordat de mens biologisch onvoldoende is toegerust, om de strijd met de spanningen te volvoeren. De biologische grondslag was dus volgens Rümke zeer belangrijk. Dit geldt zowel voor de verklaring van ziekteverschijnselen als ook in zijn schets van de psychische ontwikkeling (vgl. Rümke, 1933). In de menselijke ontwikkelingsgang doen zich voortdurend fasen van integratie en desintegratie voor, waarin biologische grondprincipes naast andere factoren een rol spelen.

Wat nu het zieke onderscheidt van het gezonde was niet een zaak van de natuurwetenschap of de geesteswetenschap, maar iets dat in de diagnose, in de bovengenoemde "theorie over deze zieke", blijkt. Ziek en gezond leven gaan niet vloeiend in elkaar over, Rümke herhaalde het vaak. "(...) 'klinisch' (als ik bij stoornissen van de gezonde mens van 'klinisch mag spreken) is er een zeer groot onderscheid tussen wat wij ziektekundig 'neurose' noemen en de bedoelde stoornissen van de gezonde mens" (Rümke, 1958 (1955), p. 167). Fenomenologisch 
zag Rümke ziek en gezond als kwalitatief verschillende structuren, maar objectief, psychologisch en neurofysiologisch, zag hij het als verschillende integratieniveaus (vgl. Rümke, 1958b, p. 76). Het identiek verklaren van het menselijk tekort, van de menselijke tragiek, met ziekte achtte Rümke een ernstige aanslag op de menselijke waardigheid. Het ziekelijke wekt niet dezelfde diepe weerklank als het tragische (vgl. Rümke, 1958 (1955), p. 172). In deze halverwege de jaren vijftig geschreven beoordeling van ziek en gezond steunde Rümke dus op de methoden die hij in zijn proefschrift had onderzocht.

Rümke is hier besproken als arts, als psychiater. Zijn opvatting van ontwikkelingspsychologie, geestelijke gezondheidszorg, persoonlijkheidsleer enzovoorts zijn buiten beschouwing gebleven, omdat zij buiten de grens van dit onderzoek vallen. Bij de bespreking van Rümke's opvatting van geneeskunde is gebleken dat hij voor alles een klinische psychiatrie van belang achtte. Binnen deze psychiatrie hebben allerlei geestes- en natuurwetenschappelijke methoden recht van spreken.

Evenals de hierboven genoemde vertegenwoordigers van de antropologische geneeskunde nam hij een eclectisch standpunt in.

De toetssteen werd daarbij altijd gevormd door de praktijk. Rümke hanteerde als criterium voor de geldigheid van de theorie, of hij paste op de concrete persoon, of hij kon fungeren als "theorie van deze zieke". Invoelen, "verstehen". psychoanalyse, existentiële analysen, maar ook biologische gegevens, hadden zijns inziens, een plaats in de geneeskunde, mits zij bijdroegen aan de kennis van de concrete zieke. De kennis van de individuele patiēnt, de concrete persoon, vormde voor Rümke gedurende zijn gehele loopbaan de inzet en het uitgangspunt van de geneeskunde. Op dit punt sluit zijn visie nauw aan bij de antropologische conceptie van de geneeskunde, waar immers ook "de zieke mens" en niet de wetenschap centraal stond.

Een andere overeenkomst tussen Rümke en antropologische geneeskunde is de filosofische en levensbeschouwelijke inspiratie van zijn werk. Ontwikkelingen in de fenomenologie en de existentiefilosofie vonden hun weerslag in zijn opvattingen. Ten slotte moet opgemerkt worden dat Rümke befaamd was wegens zijn klinische lessen. Evenals de antropologische geneeskundigen was hij een leermeester die zijn studenten door concrete patiēntendemonstraties, tot beter inzicht in hun medemens trachtte te brengen.

Toen hij in 1963 afscheid nam veronderstelde Rümke dat de fenomenologische antropologie zich zou handhaven binnen de psychiatrie, al merkte hij op dat door de opkomst van nieuw methodisch denken de belangstelling wat leek te verminderen. (vgl. Rümke, 1963, p. 8). Hij meende ook dat de fenomenologie zich zou kunnen handhaven, zeker als hulp bij de descriptie van ziektetoestanden (vgl. ibid., p. 14). Anderzijds zag hij vooral een grote toekomst voor de 
biochemische en neurofysiologische richting samen met de genetica en voor de sociale psychiatrie (vgl. ibid. pp. 12-13). Inderdaad zijn sindsdien binnen de psychiatrie allerlei stromingen op de voorgrond getreden, die afstand namen van het fenomenologisch en antropologisch denken. De fenomenologische descriptie is daarentegen, anders dan Rümke had voorspeld, van het toneel verdwenen. De fenomenologische psychiatrie is na het afscheid van Rũmke als leidend paradigma ten onder gegaan.

\subsection{Andries Querido (*1912)}

Andries Querido werd op 15 september 1912 geboren te Amsterdam. Na de HBS studeerde hij geneeskunde aan de Gemeentelijke Universiteit te Amsterdam. Tijdens zijn studie werkte hij als student-assistent in het fysiologischchemisch laboratorium van prof. dr. B.C.P. Jansen (1884-1962). Op 19 december 1935 promoveerde Querido bij Jansen op een proefschrift getiteld Vitamin D requirements in relation to Calcium and Phosphorus content of the diet (Querido, 1935).

In 1936 maakte Querido een reis naar de Verenigde Staten, hij werkte onder andere 6 maanden aan de "Johns Hopkins University" te Baltimore. Zoals hij beschreef in verschillende autobiografische artikelen, leverde deze reis hem veel waardevolle inzichten op (vgl. o.a. Querido, 1990). Daarbij ging het niet alleen om de kennismaking met bepaalde principes en experimentele methoden, ook andere aspecten van de wetenschap, het wetenschappelijk bedrijf, de organisatie en ook de commercialisering, maakten een diepe indruk. Sindsdien bleef hij bijzonder geïnteresseerd in de Amerikaanse publicaties en in zijn visie op de geneeskunde keert dit terug.

Nadat hij zijn artsexamen in april 1937 had behaald, werkte Querido als assistent bij de hoogleraar farmacologie S.E. de Jongh te Leiden. Na het vitamineonderzoek in Amsterdam was zijn onderzoek in Leiden vooral experimenteel endocrinologisch van aard. In september 1938 vertrok Querido naar het "Institut Pasteur" te Parijs. Daar deed hij een jaar lang onderzoek naar de groeifactoren voor micro-organismen en de praktische toepassing ervan voor de kwantitatieve bepaling van nicotinezuur in bloed. Dit werk verrichtte hij onder leiding van de microbioloog A. M. Lwoff, die hij later herhaaldelijk beschreef als een "bon patron" en een grandioos leermeester (vgl. o.a. Verbrugh, 1983).

Eind 1939 keerde Querido wegens het uitbreken van de Tweede Wereldoorlog naar Nederland terug. Na een korte periode waarin hij optrad als vervanger voor gemobiliseerde huisartsen, werd hij in Leiden assistent bij W.A. Kuenen, hoogleraar inwendige geneeskunde. Tezelfdertijd accepteerde Querido een adviseurschap bij de Nederlandse Gist- en Spiritusfabriek te Delft. Vervolgens, terwijl de omstandigheden in het bezette Nederland steeds dreigender worden, werkte hij 
op de tuberculoseafdeling van het Nederlands Israëlitisch Ziekenhuis te Amsterdam. Van 1943 tot de bevrijding in 1945 verbleef Querido in verschillende Duitse kampen.

$\mathrm{Na}$ zijn terugkeer vond Querido weer werk bij de afdeling Inwendige Geneeskunde te Leiden, ditmaal als hoofd van het klinisch bacteriologisch laboratorium. De contacten met Franse en Amerikaanse wetenschappers werden (weer) aangehaald en uitgebreid. Door een stipendium van "Organon" was Querido in staat om zich volledig te wijden aan klinisch-endocrinologisch onderzoek. Hij concentreerde zich tijdens deze studie op een indeling voor klinische verschijnselen, die een basis zouden moeten vormen voor een betrouwbare diagnostiek (vgl. Querido, 1948a: Querido, 1948b). In 1947 volgde zijn registratie als internist.

Querido werd in 1948 benoemd tot tweede hoogleraar Inwendige Geneeskunde aan de Rijksuniversiteit te Leiden, naast Kuenens opvolger J. Mulder. Binnen de inwendige geneeskunde vormden de endocrinologie en stofwisselingsziekten het terrein waar hij zich op richtte. Op dit onderzoeksgebied oogstte hij-nationaal en internationaal - wetenschappelijke erkenning. Hij wordt wel beschouwd als de grondlegger van de klinische endocrinologie in Nederland (vgl. De Graeff, 1981, p. 208). Kort na zijn hoogleraarbenoeming bood de "Rockefeller Foundation" Querido de mogelijkheid om een jaar door te brengen aan het met de "Harvard Medical School" verbonden "Massachusetts General Hospital" in Boston. Hij richtte zich daar op schildklierziekten, een onderwerp dat hem blijvend zou bezighouden. Op het terrein van het schildklieronderzoek telt hij als een internationaal vermaard deskundige. Door zijn werk in de schildklierfysiologie heeft Querido een voorname bijdrage geleverd aan de preventieve geneeskunde, met name in de Derde Wereld.

Terug in Nederland had Querido moeite met de Nederlandse opvatting van de functie van het academisch ziekenhuis en met de bestaande scheiding tussen theorie en praktijk. Hij heeft zich gedurende de rest van zijn loopbaan beijverd om de ontplooiing van de universiteit, zowel in personeel en voorzieningen als in theorie en onderzoek, te stimuleren. De vormgeving en kwaliteitsverbetering van het medisch wetenschappelijk onderwijs is een thema dat hem eveneens blijvend ter harte is gegaan (vgl. Köhler, 1998). Hij heeft veelvuldig deel uitgemakt van door de overheid ingestelde commissies, die zich bogen over de ontwikkeling en sturing van de academische geneeskunde in Nederland. Tot na zijn emeritaat heeft hij zich beziggehouden met de ontwikkeling van de geneeskunde als wetenschap (vgl. Querido, 1994).

In 1965 werd Querido gevraagd als voorzitter van de nieuwe medische faculteit in Rotterdam. Zowel op het gebied van het onderwijs, als op dat van het personeel en de behuizing, kon hij zijn invloed doen gelden. Hij ontwierp een opleiding die duidelijk afweek van het aan de andere universiteiten gangbare curriculum. Onder andere werd er nadrukkelijk aandacht besteed aan de 
training tot zelfstandige onderzoeker (vgl. Querido, 1966: Querido \& Rexed, 1967). In 1971 keerde Querido terug naar Leiden, waar weer werd voortgebouwd op het onderzoek naar de patho-fysiologie van de schildklier en de epidemiologische beschrijving en preventie van het endemisch cretinisme. In 1983 nam hij afscheid van het ambt van hoogleraar.

Querido heeft een belangrijk stempel gedrukt op de Nederlandse geneeskunde. Op het gebied van het wetenschappelijk onderzoek en het medisch onderwijs bekleedde hij tientallen jaren een vooraanstaande positie. Hij genoot nationaal en internationaal een hoog aanzien. Daarom wordt Querido in deze studie besproken. In zijn denken over geneeskunde was Querido sterk beïnvloed door de ontwikkelingen in de Verenigde Staten en door de conceptie van geneeskunde die daar opgeld deed. Op het gebied van de theorievorming en de daaraan gekoppelde onderzoekstraditie liep Nederland zijns inziens achter bij de internationale ontwikkelingen. Een ook wat betreft de aard van de opleiding en de faciliteiten kon Nederland, volgens Querido, de vergelijking niet doorstaan. Men was naar zijn mening nog blijven staan bij de morfologie en de pathologische anatomie. In het Angelsaksisch gebied werd daarentegen patho-fysiologisch gewerkt; bij ziekten werd gedacht in functies en er werd gekeken naar de manier waarop een ziek, ontregeld lichaam functioneert. Querido heeft zijn studenten en staf ook tot een dergelijke visie willen opleiden. (vgl. Querido, 1948c, pp. 17 18; Querido, 1990, p. 147).

Querido wilde zelf in zijn werk deze functioneel gerichte patho-fysiologische benadering naar voren te brengen aan de hand van klinisch onderzoek rond het disfunctioneren van de schildklier. Hij prees de patho-fysiologische aanpak van onder anderen F. Albright (1900-1969) aan, door bijvoorbeeld te verklaren dat alle vroegere schemata, die werden gebruikt bij de diagnostiek van de ziekten der bijnierschors, op pathologisch-anatomische basis waren gemaakt. Het schema van Albright zou de eerste indeling zijn, die werd opgesteld op pathologischfysiologische grondslag (vgl. Querido, 1947, p. 3113). Bij de diagnostiek van dergelijke stoornissen bleek het moeilijk om de symptomen in verband te brengen met een bepaald pathologisch-anatomisch substraat. De vooruitgang in de klinische endocrinologie zou ermee gebaat zijn als onderzoekers de complexe symptomatologie niet anatomisch maar vanuit de fysiologie trachten te analyseren (vgl. Querido, 1949, p. 3392).

Regelmatig heeft Querido zich gemengd in de toenmalige discussies over endocrinologische meetmethoden. Nadrukkelijk keerde zich tegen de suggestie dat uitvoerige laboratoriumanalysen automatisch de diagnose zouden kunnen verstrekken. Zijns inziens zijn dergelijke analyses één der vele onderzoeksmethoden, die in het ene geval meer dan in het andere kunnen bijdragen aan het stellen van de diagnose. Nauwkeurig klinisch onderzoek was zijns inziens een eerste vereiste (vgl. Querido \& Huis in 't Veld, 1947, pp. 3255 e.v.). 
Zijn oratie, getiteld De betekenis van de pathologische physiologie voor de geneeskunde, wijdde Querido voor een belangrijk deel aan het ziektebegrip (Querido, 1948c). Hij presenteerde zijn visie onder geleide van het volgende citaat van Claude Bernard uit diens Lecons de Pathologie expérimentale, "L'objet des études du médecin est le malade et c'est la clinique qui lui en donne la connaissance (...) c'est en effet par l'alliance féconde de la clinique et de la physiologie, que nous verrons se réaliser les progrès si vivement désirés par tous les amis de la médicine positive" (ibid., p. 2). Querido betoogde dat de pathologische fysiologie steeds meer inzicht brengt in de samenhang der ziekteverschijnselen en daarom steeds vaker een richtlijn kan vormen voor de geneeskunde.

Praktische geneeskunde is weliswaar een empirische wetenschap, zo verklaarde hij, maar de empirie, opgevat als de eigen en overgeleverde ervaring levert onvoldoende aanwijzingen voor de behandeling van patiënten. Inzicht in ziekteprocessen, die op hun beurt weer worden vergeleken met normaal functioneren, is onontbeerlijk. Hoewel voor een "beoefenaar der natuurwetenschap, die zich de studie der geneeskunde tot taak stelt" de constructie - eerst de fysiologie, dan de studie der ziekteverschijnselen en tenslotte de behandeling van de patiểnt - zo vanzelfsprekend en logisch lijkt, aldus Querido, strookt dat niet met de feitelijke ontwikkelingen in de geschiedenis van de geneeskunde. Daar lijkt eerder de omgekeerde weg te zijn bewandeld. Vooruitgang in de geneeskunde betekent niettemin, volgens Querido, dat dit ideale patroon wel wordt gevolgd en dat de patho-fysiologie tot richtlijn wordt waar de empirie tekort schiet (vgl. ibid., p. 3 en p. 21).

Querido beschreef in zijn oratie kort de voortgang in de geneeskunde. Hij constateerde: "Ziekte als zodanig is abstract; er bestaan alleen zieke mensen" (ibid., p. 4). In de Griekse geneeskunde werd zijns inziens terecht ziekte met het individu verbonden. Vervolgens besteedde Querido aandacht aan negentiende-eeuwse voorvechters van een (natuur)wetenschappelijke geneeskunde. Bernards stellingname dat ziekte slechts een afwijking vormt van het normale levensproces achtte hij ook nu nog, indien welbegrepen, van groot belang. De recente ontwikkelingen in de geneeskunde leiden, zo constateerde hij, tot een aanscherping van dit ziektebegrip. Met name de vragen "Wat is normaal?", "Wat staat tegenover normaal?" en "Wat is het verschil tussen een anomalie en een ziekte?", brachten Querido tot de volgende expliciete bepaling van ziekte: "We noemen iemand ziek wanneer hij niet bestand is tegen de gewone psychische en lichamelijke eisen die door het dagelijkse milieu aan hem worden gesteld. Het ziekmakend proces maakt het leven onder die omstandigheden onmogelijk. Worden de omstandigheden gewijzigd, door bijvoorbeeld de patiënt in bed te leggen of extra zuurstof toe te dienen, dan kan onder die nieuwe omstandigheden leven mogelijk zijn. Zodra een nieuwe toestand is ontstaan, waarbij het individu de gewone dagelijkse psychische en lichamelijke eisen die aan hem worden gesteld weer kan verwerken is hij niet ziek meer" (ibid., pp. 17-18). Een aangetast 
aanpassingsvermogen, het niet meer opgewassen zijn tegen de alledaagse inspanningen, vormde voor Querido de toetssteen om van ziekte te spreken. Niet bestand zijn tegen psychische eisen, die in het gewone leven gesteld worden, telde voor Querido overigens ook als een belangrijk criterium bij ziekte. Expliciet noteerde hij elders dat patiênten die door hun klachten een sociale mislukking vormen, wel degelijk als ziek moeten worden beschouwd (vgl. Querido, 1947, p. 3110).

Individuele verschillen in de ziekteverschijnselen maken, zijns inziens, een pathofysiologische aanpak noodzakelijk. "Wij merkten reeds eerder op, dat ziekte verbonden is met het individu; het is het ziekmakend proces met alle verstoorde normale functies en de reacties daarop, zowel lichamelijk als psychisch, dat wij ziekte noemen. De plaats der handeling is de sfeer der functies. De studie der functies van de zieke mens is dus nodig voor het inzicht in het ziekte-proces" (Querido, 1948c, p. 18). De pathologische anatomie en de morfologie kunnen wel bijdragen tot de kennis van het ziekteproces, maar de complexiteit van de gewijzigde functies, de reacties en de aanpassingen, vereisen toch een pathologische fysiologische optiek. Overigens verklaarde Querido met nadruk dat in Bernards definitie voor "état pathologique", niet één gewijzigde functie maar het gehele complex van aan elkaar gerelateerde reacties tijdens de ziekte gelezen dient te worden.

Zijn keuze voor een patho-fysiologische benadering in de geneeskunde plaatste Querido in het kader van een uitgesproken belangstelling voor de zieke mens (vgl. o.a. ibid., p. 4 en p. 24). Maar bij Querido diende het concept "de zieke mens", in tegenstelling tot de gangbare opvatting binnen de antropologische geneeskunde, niet als aanduiding voor het specifiek menselijke van ziekzijn. Zieken vertonen ziekteverschijnselen, ze hebben klachten, en de arts levert hiervan de interpretatie. Er zijn allerlei individuele variaties, geen twee patiënten zijn identiek. De nadruk op het "persoon zijn" van de zieke gevoed door een expliciete wijsgerig antropologische stellingname, die kenmerkend was voor de continentale antropologisch georiënteerde geneeskunde, treft men bij Querido niet aan. Zijn pleidooi voor de scholing aan het ziekbed vertoont verwantschap met een levenswetenschappelijke notie van de individualiteit van de zieke, zoals die in de Angelsaksische landen gangbaar was.

Ook in latere publicaties wees Querido er op dat ziekte geen vooraf gedefinieerd of absoluut begrip is. Ziekten bestaan omdat artsen een breed scala van klachten en afwijkingen die in aard en ernst kunnen variëren, groeperen en als een bepaalde ziekte bestempelen. Iedere ziekte vertoont daarom een breed spectrum, er zijn lichte en ernstige vormen van bepaalde ziektebeelden (vgl. Querido, 1980, pp. 5-6). Wanneer organismen van buitenaf of van binnenuit worden aangevallen, ondergaan ze die aanval niet passief, maar wordt er een aantal afwerende en soms corrigerende tegenacties ontketend (vgl. ibid., p. 9). 
In hun opleiding behoren artsen deze ziektebeelden als patronen te herkennen. Daartoe was volgens Querido een medische opleiding nodig die zich profileert als "education". Om in staat te zijn ziektepatronen te onderkennen moet een arts zijn scholing hebben ontvangen "door academici van hoog gehalte" (Querido, 1966, p. 6). Maar, Querido vergeleek ook op het punt van de opleiding Nederland in negatieve zin met de Angelsaksische landen, de Nederlandse samenleving is er niet in geslaagd "tijdig vernieuwingen van universitaire werkstrukturen door te voeren" (ibid., p. 7). In Rotterdam trachtte hij in elk geval een aantal verbeteringen door te voeren. Onder "education" vatte Querido enerzijds de wetenschappelijke training, die zich niet alleen beperkt tot instructie. Het ging hem dan om een wetenschappelijke training in de basiswetenschappen, morfologie, biochemie, fysiologie, bacteriologie, genetica, statistiek, psychologie, farmacologie en pathologie. De kennis van de basiswetenschappen was zijns inziens functioneel, omdat zij tezamen de humane biologie vormen. En geneeskunde zonder humane biologie achtte hij ondenkbaar (vgl. Querido, 1964. pp. 15 e.v.).

Daarnaast was klinisch basisonderwijs, onderwijs aan het ziekbed, buitengewoon belangrijk volgens Querido. Studenten behoren ook daarin degelijk te worden opgeleid. In zijn oratie schreef hij, zoals in het bovenstaande al is vermeld, dat er alleen zieken zijn, geen ziekten. Om zieken goed te kunnen beoordelen dienen studenten een intensieve denktraining dienen te ondergaan. Hij schreef achttien jaar later: "De vorming van de studenten zal er op gericht zijn dat ze duidelijk 'weten van niet weten' leren te onderscheiden en 'oordeel van vooroordeel' " (Querido, 1966, p. 4). Dat Querido een uitgesproken voorstander was van een rationalisering van het klinisch denken en handelen, blijkt bijvoorbeeld ook uit zijn gelijknamige, tezamen met Lubsen bewerkte, Nederlandse uitgave van het in 1976 verschenen boek Rational diagnosis and Treatment van de hand van de eerder genoemde Deense internist H. Wulff (Querido \& Lubsen, 1980). Om klinische oordelen te leren vellen heeft men een goede leermeester nodig die patroonherkenning leert, aldus Querido. In zijn afscheidsrede schreef hij: "Ziekte is, hoe men dit begrip ook definieert, niet iets dat van de hulpvragende kan worden geïsoleerd. Zonder patiënt is er geen ziekte. Men is het erover eens dat de arts bij het herkennen van wat er met iemand aan de hand is, via het luisteren naar klachten en het al of niet vaststellen van afwijkingen, een mechanisme van patroonherkenning volgt. Bij dit proces hoort bijvoorbeeld of de patiềnt een zieke indruk maakt, hoe hij of zij met vaak nauwelijks waarneembare emoties op een delicate vraag reageert. Bij dit proces hoort ook de relatie van de patiënt tot zijn of haar omgeving, kortom het gaat om een totale indruk. (...) Tijdens het contact van de zieke met de arts ontstaat bij deze een beeld van één 
of meer patronen waarin de klachten en afwijkingen passen. (...) Studenten moeten onder zeer degelijke leiding heel veel patronen en patroonvarianten hebben gezien Het gaat in de geneeskunde niet om de waarneming van enkele parameters, zoals bij een experiment waarbij een mens ontbreekt. In de tegenwoordige tijd is het leren herkennen van klinische patronen meer dan ooit nodig, (...)" (Querido, 1983, p. 6). Querido bepleitte in dit verband een bredere aandacht voor medische besliskunde. Niet om de concrete patiênt uit het oog te verliezen, maar om beter gefundeerd in concrete gevallen te kunnen beslissen. In zijn schets van de medische opleiding sneed Querido wel een antropologisch thema aan. In het curriculum moet men er zich rekenschap van geven dat het in de geneeskunde om zieke mensen gaat. Het mens-zijn van de zieke heeft mag niet veronachtzaamd worden. Geneeskunde daarom is wezenlijk anders dan andere wetenschappen, aldus Querido: "Voor de medische studenten wordt er echter nog een extra facet aan toegevoegd. Zij bestuderen de gezonde en zieke mens en worden hierbij gedwongen zich te bezinnen op het mens zijn en op menselijke waarden. Het doet er niet toe welk specialisme zij tenslotte uitoefenen, steeds zullen zij een verantwoorde houding moeten zoeken ten aanzien van humaan-biologische, menselijke problematiek" (Querido, 1966, p. 4).

Querido is de laatste van de hier beschreven artsen, die allen bepalend zijn geweest voor de ontwikkeling van de geneeskunde als wetenschap in Nederland. Uit zijn opvatting van de geneeskunde blijkt dat de discussies uit de geschiedenis niet zijn afgesloten. Men kan er trekken van verschillende eerder besproken concepties van geneeskunde, in ontdekken. Zijn afwijzing van de exclusieve aandacht voor de pathologische anatomie en morfologie, die hij specifiek achtte voor de Nederlandse geneeskunde, en zijn pleidooi voor de patho-fysiologie positioneerden Querido ook in zijn eigen ogen in het natuurwetenschappelijke spoor in de geneeskunde. Als ziekte door hem wordt beschreven als een gevolg van bedreiging, als een reactie op verstoorde functies, of als het niet meer opgewassen zijn tegen de normale eisen van het bestaan, lijkt hij eerder aan te sluiten bij een levenswetenschappelijke dan bij een antropologische conceptie van de geneeskunde. Dat zelfde geldt voor Querido's pleidooi om binnen de geneeskunde meer de nadruk te leggen op de pathologische fysiologie en de humane biologie. De continentale nadruk op de mens als betekenisgevende "persoon" is bij hem vrijwel niet terug te vinden. Expliciete reflectie op "de mens" of de formulering van een eigen mensbeeld evenmin. Wel vroeg hij aandacht voor het individu in diens context en de verschillende waarden die daarmee samenhangen. Hiermee raakte hij aan onderwerpen uit de antropologische traditie. In dit verband past ook zijn telkens terugkerend pleidooi voor scholing aan het ziekbed. 
Mensenkennis, iets waar door de voorvechters van de antropologische geneeskunde veel waarde aan werd gehecht, was ook volgens Querido onontbeerlijk in de geneeskunde. Voor Querido geldt eveneens dat hij de praktijk van groot belang achtte en dat hij meende dat hieraan in de opleiding op hoog niveau recht gedaan moet worden. In 1994 noemde hij de patiênt in relatie met zijn omgeving "the object of medicine" (Querido \& Van Gijn, 1994, p. 76). Hij bekritiseerde de naar zijn mening te grote specialisatie en fragmentatie. Daartegenover bepleitte hij een verbreding van de horizon binnen de geneeskunde en de ontwikkeling van integrerende concepten. In dat verband zou zijns inziens de systeemtheoretische benadering onderzoek verdienen (Querido, 1994, pp. 3 e.v.). Querido lijkt zo op een geheel eigen wijze de drie in deze studie besproken tradities in zich te verenigen. 


\section{Ter afronding}

\subsection{Terugblik en verantwoording}

In deze studie stond het thema van de ontwikkelingen in de geneeskunde, sinds zij zich in de jaren veertig van de negentiende eeuw als "echte" wetenschap heeft geprofileerd, centraal. Deze ontwikkelingen zijn vanuit een filosofische vraagstelling bestudeerd. Het betreft een analyse en een historische reconstructie van de binnen de geneeskunde gehanteerde concepten, alsmede een beschrijving van de argumenten op grond waarvan zij destijds werden verdedigd, verworpen of verlaten.

Er is binnen de geneeskunde een onderscheid gemaakt tussen drie wetenschapsidealen: het natuurwetenschappelijke, het levenswetenschappelijke en het antropologische. Deze vormden in Nederland in de besproken periode, 1840 tot 1970. achtereenvolgens het referentiekader dat het meest op de voorgrond stond bij de beoefening van de geneeskunde als wetenschap. Dat wil echter niet zeggen dat binnen de betreffende idealen dezelfde visies gedeeld zouden worden: er was wel degelijk sprake van nuances. Bovendien waren er altijd personen en groepen die zich er tegen verzetten. Maar de genoemde opvattingen werden destijds wel beschouwd als de heersende opinie binnen de geneeskunde, ze kunnen worden gekenschetst als het toenmalige paradigma.

Bij de analyse van de wetenschapsidealen is nagegaan welk doel men zich stelde en met welke middelen men dit trachtte te bereiken. Opvattingen over het object van de geneeskunde, over de geëigende onderzoeksmethoden en over de relevantie van het onderzoek zijn daarbij aan de orde gesteld. Een belangrijk punt bleek telkens de vraag naar de positionering van de geneeskunde ten opzichte van de andere wetenschappen. Geneeskunde onderscheidt zich van oudsher niet zozeer door haar onderwerp van andere academische disciplines, als wel door de omstandigheid dat ze uitdrukkelijk een praktisch doel dient: in de geneeskunde is wetenschappelijke kennis geen doel op zich maar veeleer een middel om een bepaald doel te bereiken, te weten het menselijk welzijn, de bevordering van gezondheid en het verhelpen van ziekte (vgl. o.a. Wulff, 1994, p. 11). Dat bijzondere karakter neemt niet weg dat de geneeskunde zich in de besproken periode wel uitdrukkelijk als wetenschap presenteerde: als natuurwetenschap, levenswetenschap of menswetenschap. De gerichtheid op de praktijk werd daarbij op verschillende manieren verdisconteerd. In de voorgaande hoofdstukken trad dit met name naar voren bij de bespreking van het ziektebegrip en het klinisch oordeel. 
In de beschrijving van de verschillende wetenschapsconcepten is een historische benadering gehanteerd. Het betrof dus niet, zoals bij Rothschuh en anderen, een systematische analyse van de onderscheiden concepten. Het ging om het discursieve en historische karakter van de geneeskunde als wetenschap. Daarom is ook gekozen voor een onderscheiding van wetenschapsidealen als paradigmata. De historische analyse van de wijze waarop de concepten werden geformuleerd en verdedigd door belangrijke representanten vormde de kern van het onderzoek. Dat betekent dat het niet de opzet is geweest om ze als afgeronde, historisch aantrefbare gehelen voor te stellen. De onderscheiden paradigmata moeten veeleer worden gezien als specifieke antwoorden die in de loop der geschiedenis op de vraag naar de rationaliteit van de geneeskunde werden gegeven. Ze zijn als zodanig niet alleen verhelderend omdat ze onze horizon verbreden, maar kunnen ons ook iets leren over de aard van de geneeskunde als wetenschap. De genoemde conceptuele schema's hebben als gemeenschappelijk kenmerk dat ze elk als een uitdrukking van het wetenschappelijk karakter van de geneeskunde kunnen worden beschouwd. De vorm van wetenschapsgeschiedenis die hier is gepresenteerd, kan worden gekenschetst als een combinatie van een empirische en normatieve reconstructie. Het ging hier, om nogmaals met Apel te spreken, om een hermeneutische cirkel die het mogelijk maakt van de geschiedenis te leren (zie boven; vgl. Apel, 1982, p. 12).

De gekozen werkwijze brengt met zich mee dat er op een bepaalde manier is omgegaan met de verschillende wetenschapsidealen. De innerlijke samenhang die in elk paradigma werd ontwikkeld, alsmede de legitimatie daarvan in de discussie met mede- en tegenstanders, stonden centraal in de historische reconstructie. Zoals eerder is aangegeven, dient volgens Bernstein bij een onderzoek naar de rationaliteit van wetenschap aandacht geschonken te worden aan conflicterende theorieën, paradigmata, onderzoeksprogramma's en -tradities vanuit een historisch perspectief. Omdat rivaliserende paradigmata incommensurabel zijn, kunnen ze niet puntsgewijs tegen elkaar worden afgemeten of op een uiteindelijk eenvormige methode worden afgewogen. Niettemin is naar de mening van Bernstein een onderlinge vergelijking wel degelijk mogelijk. Winst en verlies kunnen immers worden gesignaleerd, terwijl ook de argumenten pro en contra van rivaliserende paradigmata op hun merites kunnen worden beoordeeld. De diverse paradigmata zijn niet zozeer als afgeronde opinies gepresenteerd en gereconstrueerd, maar er is juist ook aandacht besteed aan de opkomst en neergang daarvan. In dit kader is een beeld gegeven van het optimisme en de strijdlust, de zekerheid en overtuiging, maar ook de onvrede, obstakels en doodlopende wegen met betrekking tot de diverse paradigmata, dit alles ten behoeve van een beter inzicht in datgene wat er op het spel staat in de geneeskunde als wetenschap en de wijze waarop zich dat historisch heeft ontwikkeld. 
De opeenvolging van historische wetenschapsconcepten is in de voorgaande hoofdstukken beschreven als een zich wijzigende constellatie van conceptuele kaders, gedragen door argumentatie en debat, $\mathrm{Er}$ is in dit verband aandacht besteed aan de wijze waarop deze concepten elk een samenhangend geheel vormden, maar er is ook een beschrijving gegeven van de wijze waarop ze werden verdedigd en bekritiseerd. Uit de reconstructie komt naar voren dat ze elk een eigen aantrekkingskracht bezaten, maar ook nadelen in zich borgen. In de discussies werden zo, naast de verdiensten, ook de beperkingen van de verschillende opvattingen aan de orde gesteld.

In de reconstructie is duidelijk geworden dat er niet een vastomlijnd aantal dimensies bestaat, waarmee de verschillende paradigmata in kaart kunnen worden gebracht. Elk wetenschapsideaal is een oorspronkelijke synthese, waarin meerdere elementen herkenbaar zijn, zij het niet als isoleerbare entiteiten. Er bestaat een verwantschap van deze elementen tussen de verschillende idealen, maar ze zijn niet identiek. Wetenschapsconcepten bleken filosofische noties en ideeën te integreren met hoopvolle verwachtingen, inspirerende voorbeelden en ook opvattingen over de juiste vraagstellingen en methoden.

Het onderzoek waarvan hier verslag is gedaan, begint met de ontwikkelingen rond 1840. Dat is de periode waarin de geneeskunde zich tot een zelfstandige wetenschap wist te verheffen. Het wetenschappelijk karakter van de geneeskunde werd in deze periode fel verdedigd. Het pleidooi voor de natuurwetenschappelijke opvatting van geneeskunde berustte in belangrijke mate op onvrede met de oudere ideeën en praktijken. Men wilde afrekenen met de machteloosheid van een geneeskunde die louter op classificatie en descriptie was gericht. Vanwege zijn statisch karakter werd ook het ontologisch ziektebegrip verworpen. Therapeutisch nihilisme werd ingewisseld voor de hoop dat de geneeskunde uiteindelijk, dankzij de kennis van fysische en chemische wetmatigheden, in staat zou zijn iedereen te genezen. Deze visie werd geschraagd door een scala van vooronderstellingen, onder andere dat geen enkel empirisch fenomeen onttrokken is aan het gezag van fysische en chemische wetmatigheden en dat de geneeskunde zich moet richten op processen. Publicaties over natuurwetenschappelijk getint medisch onderzoek, dat bijvoorbeeld was verricht met behulp van de microscoop, droegen bij aan de verspreiding van de natuurwetenschappelijke oriëntatie. Filosofische en religieuze stellingnames werden buiten de wetenschap verbannen, omdat ze de blik zouden vertroebelen. Uit dergelijke motieven ontstond een nieuwe visie op de geneeskunde, een nieuw paradigma.

De opkomst van de levenswetenschappelijke geneeskunde is beschreven vanuit een worsteling met het probleem hoe de overgang van gezond naar ziek verklaard kon worden. De natuurwetenschappelijke geneeskunde bleek voor deze vraagstelling geen sluitende oplossing te bieden. Dat gold ook voor de stromingen waar men destijds veel van verwachtte: de bacteriologie en het energetisme. 
Door beide werd een kernpunt van de natuurwetenschappelijke benadering ver doorgevoerd: respectievelijk de lineaire mono-causale verklaring en het reductionisme. In de discussies rond de kracht en beperkingen van de bacteriologie werden noties als constitutie en dispositie nieuw leven ingeblazen, en hierdoor de notie dat niet alle mensen gelijk zijn. Dit ging evenwel gepaard met het onderschrijven van een belangrijk aspect van de natuurwetenschappelijke geneeskunde. Het ontologisch ziektebegrip, dat in de bacteriologie een nieuwe legitimatie leek te vinden, werd ook in de levenswetenschappelijke geneeskunde veroordeeld. De aantoonbare aanwezigheid van een ziekteverwekker kon niet als een afdoend criterium worden beschouwd om van ziekte te kunnen spreken, zo werd gesteld. Het energetisme werd op zijn beurt verweten dat de geneeskunde niet als aparte discipline gehandhaafd kon worden, indien van elke kwaliteit werd geabstraheerd. Extreme vormen van reductie mogen wetenschappelijk acceptabel zijn, zo meende men, maar een wetenschappelijke geneeskunde is er niet bij gebaat. Deze heeft behoefte aan inhoudelijke maatstaven. Het zwaartepunt bij de beoordeling werd zodoende verlegd van de verstoorde processen naar het disfunctioneren van het individuele organisme. Voor een dergelijke geneeskunde werd ook de strikte scheidslijn tussen wetenschap en metafysica niet acceptabel geacht. In de discussies kwam aldus een nieuwe optiek tot stand, de levenswetenschappelijke geneeskunde.

De formulering van het antropologische wetenschapsideaal is beschreven als een antwoord op de vraag naar de betekenis voor de geneeskunde van het feit dat de zieke een (mede)mens is. De achtergrond hiervan was dat de levenswetenschappelijke geneeskunde tegenover de universaliserende natuurwetenschappelijke oriëntatie een individualiserende benadering had gesteld. De verdere uitwerking daarvan leidde tot een discussie over de status van de zieke voor de geneeskunde. Er werd betoogd dat het in de geneeskunde niet ging om het zieke individu als onderdeel van de levende natuur, zoals in de levenswetenschappelijke geneeskunde werd gesteld. De zieke mens, zo luidde het argument binnen de antropologische geneeskunde, zou het uitgangspunt moeten vormen, zowel in de reflectie op de medische praktijk als in de praktijk zelf. Wezenlijk voor deze geneeskunde was haar visie op de menselijke zijnswijze. Ziekzijn werd beschouwd als een wijze van menselijk existeren, waardoor de zieke als "persoon" werd gezien. De filosofische stellingname dat de mens de biologische werkelijkheid te buiten gaat, dat hij in de kern meer en anders is dan loutere natuur, had volgens de antropologische geneeskunde consequenties voor de wetenschappelijke bestudering van de mens. Mensen zijn als personen niet te vatten in objectieve bepalingen, zo luidde het argument. Zij ontplooien zich en ontwikkelen zich voortdurend. Een persoon geeft gestalte aan zichzelf en daarbij speelt de relatie met anderen een wezenlijke rol. Vanuit deze optiek heeft ziekte 
een bepaalde betekenis binnen het kader van de levensloop. De ontsluiting van deze betekenis binnen de arts-patiênt relatie kan niet worden beschouwd als de ontsluiering van een vastliggende situatie, zo werd vanuit de antropologische geneeskunde benadrukt.

In de levenswetenschappelijk georiënteerde geneeskunde werden natuurwetenschappelijke uitgangspunten bekritiseerd. De antropologische opvatting behelsde van haar kant een reactie op beide andere. De betreffende discussies zijn niet tot een einde gebracht en hebben evenmin tot definitieve conclusies geleid. $\mathrm{Zij}$ hebben echter wel duidelijk gemaakt welke thema's in de geneeskunde als wetenschap op het spel staan. Deze thema's zijn nog steeds actueel. Ook de invulling ervan in de verschillende besproken paradigmata is heden ten dag nog relevant. De stellingnames uit het verleden hebben sporen nagelaten, die ook in huidige discussies een rol spelen.

\subsection{Geneeskunde als wetenschap}

Dit onderzoek is uitgegaan van de vooronderstelling dat een historische verkenning van de binnen de geneeskunde gehanteerde concepten een bijdrage kan leveren aan het inzicht in de status van de geneeskunde. Daarbij gaat het in de eerste plaats om een inzicht in de geneeskunde als wetenschap: welke betekenis moet worden gehecht aan het feit dat de geneeskunde zich als een wetenschap beschouwt? Door de nadruk te leggen op verschillende wetenschapsopvattingen is het onderliggend patroon van het streven naar rationaliteit aan het licht getreden. Dat kwam niet alleen in de theorievorming aan het licht, maar ook in de wetenschappelijke discussies zelf. Daaruit bleek dat het begrip "waarheid" niet geassocieerd moet worden met onomstotelijke feiten of vondsten. Het betreft veeleer een constructie binnen de context van een voortdurend discursief proces, waarvan hier voor de betreffende periode een reconstructie is gegeven. Uit de in deze studie gemaakte reconstructie blijkt dat de binnen de geneeskunde naar voren gebrachte waarheden en idealen, op kortere of langere termijn, steeds weer het voorwerp van kritiek werden. Ook het streven naar betere theorieën heeft nooit tot een algemeen aanvaard eindpunt geleid, met hoeveel verve en overtuigingskracht zij ook naar voren zijn gebracht. De conclusie moet wel luiden dat voor de geneeskunde geldt wat ook voor de andere wetenschappen opgaat: er is geen absolute of laatste waarheid; er is slechts sprake van tijdelijke, door de historische en discursieve context bepaalde, waarheden.

Anderzijds is uit de studie ook duidelijk geworden dat een relativisme, in de zin van willekeur, geen steekhoudend perspectief biedt op de geschiedenis van de geneeskunde. Er is weliswaar sprake van een zekere incommensurabiliteit tussen 
de verschillende wetenschapsopvattingen, maar dat betekent niet dat ze als monaden tot afgesloten gehelen herleid zouden moeten worden en ontoegankelijk zouden zijn voor ons begrip. Het gaat evenmin om loutere standpunten of referentiekaders, die we naar believen zouden kunnen aanhangen of niet. Het is bovendien niet mogelijk om terug te keren tot de wereld van bijvoorbeeld de negentiende-eeuwse natuurwetenschappelijke geneeskunde. Wij leven nu eenmaal in een andere wereld, een wereld die getekend is door de ontwikkelingen die zich sindsdien hebben voorgedaan en waar we niet zomaar kunnen uitstappen.

Verwijzend naar Bernsteins opvatting van wetenschapsfilosofie, die zich wil ontworstelen aan de beklemmende "cartesiaanse angst". betekent dit dat er voor een tussenweg wordt gekozen tussen objectivisme en relativisme. Met Gadamer beklemtoont Bernstein dat men zich moet realiseren altijd onderweg te zijn. maar dat men tegelijk verantwoordelijkheid dient te nemen voor de eigen keuzen (vgl. Bernstein, 1983, p. 166). Dat geldt onverminderd voor de wetenschap. Ook de wetenschap is immers voortdurend onderweg met aanspraken op waarheid en geldigheid, die weliswaar telkens feilbaar blijken, maar ook telkens met de beste argumenten moeten worden verdedigd. "We never escape from the obligation of seeking to validate claims to truth through argumentation and opening ourselves to the criticism of others", aldus Bernstein (Bernstein, 1983. p. 168). De erkenning van onze feilbaarheid, een consequentie van de menselijke eindigheid, levert wetenschap niet uit aan het relativisme. Het is wel degelijk zinvol om te streven naar vooruitgang. Maar vooruitgang kan niet worden gemeten aan de hand van onafhankelijke standaarden, het vergt een menselijk, gesitueerd, oordeel: "The new understanding of science does not call into question scientific progress and the growth of scientific knowledge but rather faulty epistemological doctrines that claim that progress can be measured by an appeal to a permanent ahistorical matrix or a neutral descriptive language" (Bernstein, 1983, p. 172). Het kritisch-interpretatief vermogen, dat in de beoordeling van wetenschappelijke theorieên en waarheidsaanspraken een rol speelt, wordt door Bernstein even verder als volgt verwoord: "The judgmental character of evaluating competing scientific theories and paradigms is more like the judgmental character of evaluating rival hermeneutical interpretations than Gadamer makes explicit" (Bernstein, 1983, p. 174). De in de voorgaande hoofdstukken gegeven reconstructies bieden een concreet zicht op de wijze waarop dergelijke evaluaties in de praktijk plaatsvinden en de kwesties die daarbij een rol spelen.

De analyse van de in de geneeskunde ontwikkelde wetenschapsidealen heeft duidelijk gemaakt dat de gehanteerde argumenten van zeer verschillend karakter waren. Zoals gezegd, heeft deze studie zich gericht op de in het verleden gehanteerde wetenschapsconcepten in hun hoedanigheid van paradigma, zoals nader uitgewerkt door Kuhn. Een dergelijk paradigma bevat conceptuele schema's een 
blauwdruk van het door de wetenschap te onderzoeken domein, alsmede methodologische regels en richtlijnen over wat als relevante vragen en adequate antwoorden worden beschouwd. Binnen de geneeskunde geeft een paradigma bovendien het kader aan waarin het medisch wetenschappelijk handelen is ingebed en waardoor het wordt gelegitimeerd. De discussie tussen voor-en tegenstanders van bepaalde wetenschapsopvattingen kan derhalve betrekking hebben op zeer uiteenlopende kwesties. Dat is uit de behandelde discussies duidelijk gebleken.

In de onderscheiden perioden wordt telkens een bepaald concept van geneeskunde naar voren gebracht dat door zijn voorvechters wordt uitgedragen en op zijn implicaties wordt onderzocht, Daarbij wordt gepolemiseerd met artsen die zich daar niet voetstoots mee willen verenigen of die hechten aan noties of praktijken uit voorafgaande perioden. Nieuwe opvattingen worden, zoals we in het voorgaande hebben gezien, vaak met veel élan gepropageerd. Oudere noties worden daar tegenover als volstrekt achterhaald gepresenteerd. Bovendien wordt vaak hun schadelijke effect voor de patiënt uitgemeten. Het nieuwe zou een bevrijding en een weldaad betekenen, zowel voor de wetenschap als voor de zieke. Een voorbeeld hiervan uit de jaren veertig van de negentiende eeuw, is de manier waarop Griesinger en Virchow als jonge voorstanders van de natuurwetenschappelijke geneeskunde de visie van hun natuurhistorische voorgangers bespraken (Griesinger, 1972 (1842); Virchow, 1877, pp. 3-4).

De claims die men heeft ten aanzien van geldigheid van de geneeskundige kennis, worden, zoals we hebben gezien, op verschillende manieren gerechtvaardigd. Naast wetenschappelijke georiënteerde argumenten, spelen ook andere een rol: economische, ethische, politieke, levensbeschouwelijke, enzovoorts. Dat gebeurde bijvoorbeeld met het begrip "constitutie", dat halverwege de negentiende eeuw wegens zijn ondemocratische en conservatieve karakter terzijde werd geschoven.

Geneeskunde is, zoals elke wetenschap, een discursief proces waarbij verschillende idealen worden geponeerd en bestreden. In de geneeskunde spelen de begrippen ziekte en klinisch oordeel een centrale rol. Elk besproken concept wil antwoord geven op vragen als: wat is ziekte?, wat is de oorzaak van ziekte?, hoe spoort men ziekte op en hoe kan genezing worden bereikt? In de geschiedenis van de geneeskunde als wetenschap stuit men voortdurend op pogingen om ziekte in te kaderen in termen van de dode natuur, de levende natuur of de menselijke existentie. Dergelijke benaderingen leveren zeker resultaten op, maar ze zijn ook kwetsbaar voor kritiek. Het lukt niet om het eigen kader voor langere tijd een permanente status te geven en de overige als irrelevant te bestempelen. De geneeskunde als wetenschap is en blijft het strijdtoneel van de verschillende benaderingen. 


\subsection{Geneeskunde als praktische wetenschap}

Inzicht in de opeenvolgende wetenschapsidealen in de geneeskunde leert ons niet alleen iets over de aard van de geneeskunde als wetenschap. Weliswaar wordt de ontwikkeling van de geneeskunde gekenmerkt door argumentatie en kritiek, net als die van andere wetenschappen. Maar de verhouding tussen wetenschap en praktijk is een voortdurend probleem. Bijzonder voor geneeskunde is immers de betrokkenheid op de praktijk. Medici interveniëren in het leven van patiënten. Ze richten zich op het bestrijden van ziekten via een behandeling van individuele personen. De geneeskunde beoogt niet slechts wetenschappelijk inzicht, ze streeft naar praktische resultaten. De wijze waarop men ziekte en klinisch oordeel definieert, vormt in feite een uitdrukking van de visie op de verhouding tussen wetenschap en praktijk. Hoe wetenschappelijk ook, het oogmerk is steeds het verantwoord handelen in de geneeskundige praktijk. Geneeskunde is een praktische wetenschap (vgl. Widdershoven-Heerding, 1987).

Dit betekent dat ziektebegrip en klinisch oordeel geen willekeurige thema's zijn in de geschiedenis van de geneeskunde als wetenschap; het gaat hier om thema's die tot het hart van de geneeskunde behoren en dus constitutief zijn voor de medische praktijk. Kenmerkend voor de discussie is, dat men steeds op zoek is naar datgene wat ziekzijn onderscheidt van gezondheid. Het ontologische ziektebegrip, dat hierop een scherp antwoord poogt te formuleren, is dan ook een terugkerend thema in de discussie. Halverwege de negentiende eeuw werd het ontologisch ziektebegrip met kracht verworpen. Aan het eind van dezelfde eeuw, met de opkomst van de bacteriologie, stak het ontologisch denken evenwel opnieuw de kop op met de bacterie als "ens morbi". Vervolgens werd ook deze conceptie bekritiseerd. Maar tot in de hedendaagse discussies zijn er aanhangers van een opvatting van ziekte als aanwijsbaar "ding", als onafhankelijk natuurlijk fenomeen (vgl. Dillmann, 1990, pp. 4-5) Al lijkt het ontologische ziektebegrip tegenwoordig het pleit te hebben verloren, het is nog steeds van invloed op de hedendaagse geneeskunde (vgl. Dierickx, 1999, pp. 130-131).

De verwetenschappelijking van de geneeskunde, en dan met name van dat aspect van de geneeskunde dat zich daar het taaist tegen lijkt te verzetten, het klinisch oordeel, is eveneens een terugkerend thema. Halverwege de negentiende eeuw vestigde men de hoop op de kennis van universele fysische en chemische wetmatigheden, die zouden kunnen worden toegepast op individuele gevallen. Zo zou de wetenschap de arts in staat stellen om bij concrete zieken altijd een verantwoorde oplossing te bieden. Deze optimistische redenering bleek in de loop der tijd niet steekhoudend. Patiểnten waren minder eenvormig dan verwacht, waardoor de toepasbaarheid van universele wetmatigheden aan het ziekbed aanmerkelijk afnam. Toepassing van (natuur)wetenschappelijke kennis aan het ziekbed vergde een apart type inzicht, een klinische blik. Erkenning daarvan impliceerde niet dat de pogingen om de wetenschappelijkheid van het klinisch oordeel te funderen, werden opgegeven. Er werd naar andere vormen gezocht. 
Dat zoekproces is niet teneinde. Berg beschrijft recente Amerikaanse literatuur, waarin verschillende strategieên worden verdedigd om het wetenschappelijke gehalte van de medische praktijk te verhogen (vgl. Berg. 1995).

De geschiedenis van de geneeskunde als wetenschap, zoals hier beschreven, leert ons dat ziekte en klinisch oordeel kernbegrippen zijn in het medisch discours. Het is dan ook niet toevallig dat filosofen zich met name op deze begrippen richten en trachten ze te verhelderen. De beschouwingen die aan deze begrippen worden gewijd, pretenderen een tijdloze status te hebben en worden als universele waarheden gepresenteerd. In de jaren tachtig is in de filosofie van de geneeskunde bijvoorbeeld uitvoerig gediscussieerd over de definitie van ziekte door Boorse (vgl. Boorse, 1977, pp. 558-559). Ziekte werd door Boorse gekoppeld aan de verstoring van het "species design", een soortgebonden bouwplan. In het debat werden allerlei bezwaren geuit, vooral tegen het objectiverende karakter ervan. Er werden andere definities voorgesteld, die beter recht zouden doen aan wat ziekte eigenlijk, filosofisch gesproken, is.

Uit de voorgaande hoofdstukken blijkt evenwel dat in de loop der tijd binnen de geneeskunde verschillend over de genoemde begrippen is gedacht. $Z_{i j}$ zijn steeds ontwikkeld in de context van een paradigma en verbonden met een concrete praktijk. In de filosofische discussies wordt tot op heden hiermee onvoldoende rekening gehouden. In deze discussies worden vaak de vigerende medische standpunten weerspiegeld, of men zet zich er juist radicaal tegen af, maar zij worden niet als historische categorieën geïnterpreteerd. Ze worden veeleer opgevat als tijdloze concepten, die in algemeen geldende termen geanalyseerd kunnen worden. De filosofie van de geneeskunde zou in dit verband, als het gaat om centrale begrippen zoals ziekte en klinisch oordeel, iets kunnen leren van de wijze waarop de wetenschapsgeschiedenis tegenwoordig wordt beoefend. Hierdoor zou men meer oog krijgen voor de historiciteit van begrippen en het feit dat deze een bepaalde inhoud krijgen in praktische discussies tussen vooraanstaande vakbeoefenaars. De bijdrage van de filosofie van de geneeskunde zou in het verlengde hiervan kunnen zijn: het in samenspraak met vakbeoefenaars expliciteren van de inhoud van de kernbegrippen "ziekte" en "klinisch oordeel".

\subsection{Continuïteit en discontinuïteit}

Ziekte en klinisch oordeel zijn constitutief voor de geneeskunde. Denken over geneeskunde zonder rekenschap af te leggen van deze kernbegrippen is onmogelijk. Dat verklaart wellicht het feit dat in sommige opzichten zich weliswaar veranderingen voltrekken, maar dat van een radicale uitbanning van vorige idealen meestal geen sprake is. Dit verleidt sommigen ertoe de geschiedenis van de geneeskunde als wetenschap als een eenheid te beschouwen, waarin bepaalde visies centraal staan. 
In het laatste hoofdstuk van The Western Medical Tradition 800 BC to AD 1800 wordt nader ingegaan op het begrip "traditie", een begrip dat zich ook uitstrekt tot het heden (vgl. Neve, 1995, pp. 477 e.v.). Aan het begrip "medische traditie" zijn, zoals Neve aangeeft, een aantal vooronderstellingen verbonden. Allereerst moet een traditie zichtbaar zijn, dat wil zeggen, zij moet herkenbaar zijn in het verleden. Een traditie dient ook bepaalde maatstaven en idealen te bevatten, aan de hand waarvan vooruitgang kan worden afgemeten. Dat wil evenwel niet zeggen dat er vanuit een bepaalde traditie niet veel verschillende verhalen te vertellen zouden zijn, met een nadruk op bijvoorbeeld economische, demografische, cultureel-antropologische of sociologische aspecten. In Neves beschrijving van de ontwikkeling van de geneeskunde zijn echter toch bepaalde constanten terug te vinden. Kenmerk immers van de Westerse traditie is, aldus Neve, dat men eropuit is het ziekzijn, "illness", te verklaren aan de hand van ziekten, "diseases", bepaalde onafhankelijke en natuurlijke entiteiten: "Illness as an experience becomes replaced, or pushed to one side, as the trained doctor tracks the authentic but hidden world of disease as biological pathology. The disease entity, the object of attention, splits from the experience of suffering with which it had once been linked, (...) Medicine and its claims to see through to the disease embody the progressive ideal of the Western medical tradition. (...) The backbone of progress that makes up one version of the Western medical tradition is formed out of the possibility of succesful application of biomedicine and its technology" (Neve, 1995, pp. 481-482). Door allerlei andere beschouwingswijzen ook in hun waarde te laten, tracht Neve simplisme en vooruitgangsgeloof te vermijden. Als het echter gaat om een medische kijk op ziekte, dan is volgens Neve van een rechtlijnig proces sprake, de toenemende invloed van het biomedisch denken en het ontologisch ziektebegrip.

In het licht van dit proefschrift moet Neves conclusie als voorbarig worden beschouwd. Bij de bestudering van de ontwikkelingen van de laatste 150 jaar blijkt dat bepaalde trends in de hedendaagse discussie terugkeren. Het is niet zo dat de ontologische optiek alleen maar aan invloed wint; er is immers ook steeds weer sprake van een verzet hiertegen. Hetzelfde geldt voor het mechanicistische standpunt: het is aantrekkelijk, maar het beklemtonen van de eigen aard van de mens/levende natuur is dat evenzeer. Er is dus geen sprake van "primitieve" opvattingen, die definitief overwonnen zouden worden. Er is eerder sprake van een constant spanningsveld tussen concurrerende ideeên met hun eigen vooren nadelen. De continuiteit van bepaalde concepten en de voortdurende terugkeer van bepaalde invullingen ervan kunnen immers niet verhelen dat er vaak sprake is van veel strijd en discussie, juist ten aanzien van de centrale noties van 
de geneeskunde als praktische wetenschap. Aansluitend bij Bernstein, kan de discussie van de afgelopen 150 jaar worden gekarakteriseerd als een traditie, zij het een traditie, die door breuken wordt gekenmerkt en waarin centrale concepten steeds weer anders worden ingevuld. Als er al van een "backbone" sprake is, dan is dat die van de voortdurende discussie, dat wil zeggen, van een continuiteit van het discursieve proces. Deze "backbone" krijgt gestalte in meerdere, deels strijdige, wetenschapsidealen en niet in de suprematie van een enkel ideaal.

Vanuit kuhniaans perspectief ligt het accent van de geschiedenis meer op discontinuīteit dan continuiteit. Toch wil dit niet zeggen dat de fasen elkaar slechts afwisselen, zonder onderling verband. Wanneer een nieuw ideaal opkomt, vindt discussie plaats met het voorafgaande. Daarbij blijven elementen van het oude ideaal vaak relevant. "Since new paradigms are born from old ones, they ordinarily incorporate much of the vocabulary and apparatus, both conceptual and manipulative, that the traditional paradigm previously employed" (Kuhn, 1974 (1962), p. 149). Ondanks de bestaande incommensurabiliteit tussen verschillende paradigma's, vertoont de argumentatie binnen een nieuw paradigma een zekere verwantschap met de eerder gevoerde polemieken. Uit ons onderzoek is gebleken dat bepaalde concepten, zoals ziekte en klinisch oordeel, een rol blijven spelen, al worden zij in de loop der tijd anders ingevuld. Deze concepten moeten weliswaar niet worden gezien als variaties op eerdere versies, maar ze vertonen wel een zekere familiegelijkenis.

Behalve concepten zijn ook praktijken een langer leven beschoren. Conceptuele ontwikkelingen zijn immers gerelateerd aan praktisch handelen. De patronen in spreekkamers en ziekenhuizen blijven terugkijkend deels herkenbaar. Ook hier gaat het om familiegelijkenissen. In deze studie lag het accent op concepten en argumentaties, niet tegenover de praktijk, maar als één zijde van de medaille, waarbij de praktijk de andere zijde vormt.

Een paradigma is dat wat een wetenschappelijke gemeenschap deelt (vgl. Kuhn, 1977 (1974), p. 294). Essentieel is dat studenten worden opgeleid in de nieuwe traditie, dat ze voorbeelden krijgen van de juiste denk- en handelwijze. Ze worden opgenomen in de wetenschappelijke gemeenschap, als ze van hun leermeesters hebben geleerd om bepaalde vragen op de juiste manier op te lossen. In een praktische wetenschap als de geneeskunde zijn leermeesters bij uitstek belangrijk. Ze leveren een inspirerend voorbeeld, dat hun leerlingen later graag aanhalen. De inspiratie betreft zowel de theoretische diepgang en conceptuele scherpte, als de wijze waarop patiënten werden bejegend. 


\subsection{Lessen voor het heden}

Wat valt er uit deze studie en uit de zojuist getrokken conclusies te leren voor het heden? Allereerst dat geneeskunde als wetenschap gezien moet worden als een voortdurend proces van argumentatie en discussie. Het gaat hierin evenwel niet om het vinden van absolute waarheden, maar het overtuigen van anderen van de zin van een bepaalde benadering. Dit impliceert geen relativisme, omdat nu eenmaal niet alle argumenten even zwaar tellen. Alleen die argumenten zijn relevant die in staat zijn een nieuwe wending te geven aan reeds langer bestaande discussies, een wending die het mogelijk maakt om acute problemen aan te vatten en nieuwe praktische oplossingen te vinden. In de tweede plaats valt uit het onderzoek te leren dat geneeskunde als praktische wetenschap behoefte heeft aan discussies over de gehanteerde grondbegrippen, met name die van ziekte en klinisch oordeel. Ten slotte is het duidelijk geworden dat dergelijke discussies zich niet in het luchtledige afspelen, maar tegen de achtergrond van eerdere discussies, waarbij voorgaande idealen werkzaam blijven, al was het maar als referentiepunt.

De huidige discussie over "Evidence based medicine" vormt hiervan een voorbeeld. Onder "Evidence based medicine" wordt verstaan: " (...) the conscientious, explicit, and judicious use of current best evidence in making decisions about the care of individual patients" (Sackett e.a., 1996, p. 71). De aanhangers van "Evidence based medicine" willen individuele klinische expertise verbinden met klinisch relevant onderzoek: "It's about integrating individual clinical expertise and the best external evidence" (Sackett e.a., 1996, p. 71).

De argumenten die de aanhangers naar voren brengen ten gunste van "Evidence based medicine" zijn, evenals de bezwaren, van uiteenlopende aard. Men baseert zich niet op doorslaggevende bewijzen die de tijdloze juistheid van deze visie garanderen, maar op wat nu geldt: "current best evidence". Evenmin beroept men zich alleen op medisch wetenschappelijke gronden. "Evidence based medicine" beschouwt zichzelf nadrukkelijk niet als een "ivoren toren"-vorm van wetenschap. De principes van "Evidence based medicine" worden op veel terreinen toegepast, kindergeneeskunde, chirurgie, huisartsgeneeskunde, tandheelkunde, verpleging, enzovoorts. Men is er op uit om de praktijk te verbeteren van alle professionals in de zorg, inclusief het management. De voordelen voor de patiënt, die profiteert van zowel de individuele klinische expertise van de arts, als de beste beschikbare kennis, worden breed uitgemeten. "Doctors practising evidence based medicine will identify and apply the most efficacious interventions to maximise the quality and the quantity of life for individual patients (...)" (Sackett e.a., 1996, p. 71). De legitimatie van "Evidence based medicine" geschiedt nadrukkelijk ook via de politiek, de ethiek en de economie. 
In de discussie blijkt vooral dat men elkaar ervan wil overtuigen dat "Evidence based medicine" hét actuele voorbeeld vormt van goede en wetenschappelijk verantwoorde geneeskunde.

In de discussies over "Evidence based medicine" staan bekende vragen centraal. Wat kun je leren uit algemene kennis afkomstig uit klinische tests? "Current best evidence", wat voor kennis is dat? Hoe is het totstandgekomen? Hoe maak je er gebruik van in het klinisch oordeel? Het feit dat men bereid is om zich in de geneeskunde te baseren op de meest recente kennis, lost de vraag hoe algemene kennis te rijmen valt met een individuele behandeling, niet op. In het klinisch oordeel zullen artsen "evidence" moeten integreren in het geheel van hun bevindingen, in hun interpretatie van het verhaal van de patiênt (vgl. Greenhalgh, 1999. pp. 323-324). Bij de behandeling van zijn patiënten zal de arts telkens moeten beoordelen wat in het concrete geval de waarde is van de beschikbare kennis en de gemiddelde resultaten (vgl. Maynard, 1997, p. 128). In de geneeskunde is de vraag uiteindelijk niet: "Does it work for most patients?" maar: "Does it work for this patient?" (vgl. Mant, 1999, p. 745). In de discussie over de geldigheid van "Evidence based medicine" blijkt de verantwoording van het praktische karakter van geneeskunde een essentieel punt.

Men beoogt niet slechts wetenschappelijk inzicht, men streeft naar praktische resultaten. Hoe wetenschappelijk ook, het oogmerk is steeds het verantwoord handelen in de geneeskundige praktijk. Het gaat om de applicatie van de verworven kennis. De aanhangers van "Evidence based medicine" plaatsen zichzelf daarbij uitdrukkelijk in de traditie. Zij voeren de wortels van hun onderneming terug op het Parijs van halverwege de negentiende eeuw. "Evidence based medicine" vormt een hedendaagse uitdrukking van het streven de kwaliteit van de medische praktijk te verhogen met behulp van wetenschappelijke kennis.

De bijdrage die filosofen op dit moment kunnen leveren aan het debat over "Evidence based medicine", bestaat uit het expliciteren van de inhoud van de centrale begrippen en idealen. Daarbij zullen zij moeten samenwerken en in discussie treden met de betrokkenen uit de praktijk. Voor het voeren van een vruchtbare discussie is het van essentieel belang dat men er oog voor heeft wat op het spel staat. Het is met name dit aspect waaraan kennis van en inzicht in de geschiedenis een bijdrage kan leveren. 



\section{Literatuur}

\section{Aalbers (red.), $\mathrm{H}$.}

1938 Het mysterie van ons bestaan. Zes verhandelingen over het probleem van leven en dood, Zeist.

Achilles, $\mathbf{P}$

1974

"Krankheit und Naturbegriff bei Viktor von Weizsãcker", in:

M. von Rad (Hrsg.), 1974, pp. 47-72.

\section{Ackerknecht, E.H.}

1959 (1955) Kurze Geschichte der Medizin, (vertaling van A Short History of Medicine, New York), Stuttgart.

Apel, K.-O.

1982

"Wetenschapsgeschiedenis en het probleem van historisch begrijpen en verklaren", in: Kennis en Methode. Tijdschrift voor wetenschapsfilosofie en methodologie, VI, nr. 1, pp. 4-37.

Aschoff, L.

1925

Vorträge über Pathologie: gehalten an den Universitäten und Akademien Japans im Jahre 1924, Jena.

Baier, $\mathbf{H}$.

1988

Richard Siebeck und Karl Barth - Medizin und Theologie im Gespräch, Göttingen.

Balen, G.F. van

1933

"Functioneele Pathologie en Teleologie", in: R.K.Artsenblad, 12 , pp. 77-84.

Balmer, H. (Hrsg.)

1976

Die Psychologie des 20. Jahrhunderts, Band I, Die Europäische Tradition, Zürich.

\section{Barge, J.A.J.}

1919

Vorm en Functie, rede uitgesproken bij de aanvaarding van het hoogleeraarsambt aan de Rijksuniversiteit te Leiden den 7 en mei 1919 door Dr.J.A.J. Barge, Bussum. Wat is het leven? Drie voordrachten, op uitnoodiging van het Leidsch Universiteitsfonds gehouden voor studenten van alle faculteiten op 11, 18 en 25 maart 1935 , Leiden, Amsterdam. 
"Het totaliteitsbegrip in de biologie" in: Annalen Thijmgenootschap, 28. pp. 86-111.

1938a Praeformatic èn epigenese, rede uitgesproken op den driehonderd drie-en-zestigsten dies natalis der Leidsche universiteit, 8 februari 1938 door den rector magnificus Dr. J.A.J. Barge, Leiden.

1938b "Eenige beschouwingen over leven en dood van algemeen biologisch standpunt", in: H. Aalbers (red.), 1938, pp. 9-35.

1947 (1941) "De betrekking tusschen vorm en functie als biologisch probleem (Voordracht gehouden in de Algemeene Vergadering van 17 mei 1941)", in: Haarlemsche voordrachten, voordrachten gehouden in de algemeene vergaderingen van de Hollandsche maatschappij der Wetenschappen te Haarlem, V, Haarlem, pp. 5-23.

1949 (1944) 7 mei 1919 - Leiden - 1944. Verzameling van lezingen, toespraken, verslagen en niet in boekvorm verschenen geschriften aangeboden door zijn kinderen ter gelegenheid van zijn 25 -jarig professoraat, 2 delen, "s-Gravenhage.

\section{Belzen, J.A. van}

1988 a

$1988 b$

Zicht op synthese? H.C. Rümke's streven naar integratie in psychiatrie en geestelijke genondheidszorg, Proefschrift Rijksuniversiteit Utrecht, Utrecht. Gecondheid, ziekte an psychiatrie volgens H.C. Rümke, Zeist.

Rümke, religie en godsdienstpsychologie, Kampen.

\section{Belzen, J.A. van \& R.H.J. ter Meulen}

1988

"In de ban van de ziel. L. Bouman (1869-1936) en het ontstaan van de 'psychologische' psychiatrie", in: Tijdschrift voor Psychiatrie, 30. pp. 255-269.

Benton, E.

1974

"Vitalism in Nineteenth-century Scientific Thought: A Typology and Reassessment", in: Studies in the History and Philosophy of Science, 5. pp. 17-48.

\section{Berg, M.}

1995

Rationalizing Medical Work. Decision Support Techniques and Medical Practices, Proefschrift Rijksuniversiteit Limburg, Maastricht.

Bergmann, G. von

1932

Funktionelle Pathologie. Eine klinische Sammlung von Ergebnissen und Anschauungen einer Arbeitsrichtung, Berlijn. 


\section{Bernard, $C$.}

1855

1856

1865

1872

$(1859 / 1860)$

1957 (1865) Principes de médecine expérimentale, Parijs.

1966 (1878) Legons sur les phánomànes de la vie communs aux animaux et aux végétaux, (posthuum uitgegeven, Parijs, 1878), heruitgave met voorwoord van G. Canguilhem, Parijs.

\section{Bernstein, R.J.}

1983

Beyond Objectivism and Relativism:Science, Hermeneutics, and Praxis, Oxford.

\section{Bieganski,W.}

1909

Medizinische Logik, Würzburg.

\section{Bier, $\mathrm{A}$.}

1922

\section{Bleker, J.}

1978

Die naturhistorische Schule, 1825-1845 : ein Beitrag zur Geschichte der klinische Medizin in Deutschland, Münster.

1983 "Between Romantic and Scientific Medicine: Johann Lukas Schoenlein and the Natural History School 1825-1845", in: Clio Medica, 18, pp. 191-201.

\section{Bois-Reymond, E. du}

Untersuchungen über thierische Elektricität, Berlijn.

1875 La Mettrie. Rede in der öffentlichen Sitzung der Königl. Preuss. Akademie der Wissenschaften zur Gedächtnissfeier Friedriech's II. am 28 januar 1875, Berlijn. Ueber die Grenzen des Naturerkennens (1872), Die sieben Welträthsel (1880): Zwei Vorträge von Emil du Bois-Reymond, Leipzig. 
Bom, Th. van der

1933a

$1933 \mathrm{~b}$

Bonah, C.0.

1995

"Physiology, periodicals, and national differences at the end of the 1860 's", in: C. Debru (ed.), pp. 223-239.

\section{Boorse, $\mathrm{C}$.}

1977

"Health as a Theoretical Concept", in: Philosophy of Science, 44. pp. 542-573.

\section{Bräutigam, W. (Hrsg.)}

1980

Medizinisch-psychologische Anthropologie, Darmstadt.

\section{Brugsch, Th.}

1918

1926

1936

Allgemeine Prognostik oder die Lehre von der ärtlichen Beurteilung des gesunden und kranken Menschen, Berlijn.

"Einführung in die Konstitutionslehre, ihre Entwicklung zur Personallehre", in: Th. Brugsch \& F.H. Lewy (Hrsgs.), 1926, pp. 1-23.

Ganzheitsproblematik in der Medizin; zugleich eine Einführing in die medizinische Erkenntnislehre, Berlijn, Wenen.

Brugsch, Th. (Hrsg.)

1933

Einheitsbestrebungen in der Medizin Band I, Kongress zur Förderung medizinischer Synthese und ärtlicheWeltanschauung 1932, Dresden, Leipzig.

1935 Einheitsbestrebungen in der Medizin Band II, Kongress zur Förderung medizinischer Synthese und ärtlicheWeltanschauung 1934, Dresden, Leipzig.

\section{Brugsch, Th. \& F.H. Lewy (Hrsgs.)}

1926

Die Biologie der Person. Ein Handbuch der allgemeinen und speriellen Konstitutionslehre, Band I, Berlijn, Wenen.

\section{Bruna, $M$.}

1935

"De Systeemtheorie van het Leven", in: R.K.Artsenblad, 14, pp. 319323. 


\section{Buber, $\mathbf{M}$.}

1956

1979 (1923)

1979

"Die Kreatur", in: P. Vogel (Hrsg.), 1956, pp. 5-6.

"Ich un Du", in: M. Buber, 1979, pp. 5-136.

Das dialogische Prinzip, Heidelberg.

\section{Buck, R.C. \& R.S. Cohen (eds.)}

1971

Boston Studies in Philosophy of Science, vol. 8, Boston.

\section{Burckhardt, $\mathbf{R}$.}

1972

Historische und methodologische Aspekte der Biographik in der Medizin des 19. und 20. Jahrhunderts unter besonderer Berüdksichtigung der "Biographischen Medizin" Viktor von Weizsäckers, Freiburg in Breisgau.

\section{Burger, $\mathrm{H}$.}

1928

"Het teleologisch denken in de geneeskunde. Diesrede 8-1-1928", in: Jaarboek der Universiteit van Amsterdam 1927-1928, Amsterdam.

Buss, A.R.

1979 Psychology in social context, New York.

Canguilhem, G.

1978 (1966) Le normal et le pathologique, Parijs.

\section{Cannon,W.B.}

1932

The wisdom of the body, New York.

\section{Cassirer, E.}

1973 Das Erkenntnisproblem in der Philosophie undWissenschaft der neueren Zeit, IV. Von Hegels Tod bis zur Gegenwart 1832-1932, Hildesheim.

\section{Christian, $\mathbf{P}$.}

1952

Das Personsverständnis im modernen medizinischen Denkens, Tübingen.

\section{Christian, P. \& D. Rössler (Hrsgs.)}

1959 Medicus Viator; Fragen und Gedanken am Wege Richard Siebecks, Tübingen, Stuttgart.

\section{Conrad, L.I. , M. Neve, V. Nutton, R. Porter, A. Wear}

1995

The Western medical tradition: 800 B.C. - 1800 A.D., Cambridge. 
Cranefield (ed.), P.F.

1982

Two Great Scientists of the Nineteenth Century. Correspondence of Emil Du BoisReymond and Carl Ludwig. Oorspronkelijk gepubliceerd in 1927 als Zwei grobe Naturforscher des 19. Jahrhunderts: Briefwechsel. Collected by Estelle Du Bois-Reymond. Foreword, Notes, and Indexes by Paul Diepgen. Uitgegeven en van een voorwoord voorzien door Paul F. Cranefield, Baltimore, Londen.

Debru, C. (ed.)

1995 Essays in the History of the Physiological Sciences. Clio Medica, 33, Amsterdam, Atlanta.

Deen, J. van, F.C. Donders, Jac. Moleschott

1848 Holländische Beiträge $\mathrm{zu}$ den anatomischen und physiologischen Wissenschaften, III, Erster Band, Düsseldorf, Utrecht.

\section{Dekkers, W.J.M.}

1985 Het berielde lichaam. Het ontwerp van een antropologische fysiologie en geneeskunde volgens F.J.J. Buytendijk, Zeist.

\section{Derksen, A.A.}

1997

"Thomas S. Kuhn (1922-1996), een moderne komedie van vergissingen", in: Algemeen Nederlands Tijdschrift voorWiisbegeerte, 89, nr. 3. pp. 205-229.

\section{Diepgen, $\mathbf{P}$.}

1926

\section{Dierickx, $\mathbf{K}$.}

1999

"Krankheitswesen und Krankheitsursache in der spekulativen Pathologie des 19. Jahrhunderts", in: Archiv für Geschichte der Medizin, XVIII, pp. 302-327.

Genetisch geoond? Ethische en sociale aspectan van genetische tests en screenings, Antwerpen, Groningen.

\section{Dillmann, R.J.M.}

1990

Alzheimer's Disease. The Concept of Disease and the Construction of Medical Knowledge, Amsterdam. 
Donders, F.C.

Dissertatio inauguralis sistens observationes anatomico-pathologices de centro nervoso, Leiden.

1849-1850 "De bewegingen der hersenen en de verandering der vaatvullingen van de pia mater, ook bij gesloten onuitzetbaren schedel regtstreeks onderzocht", in: Nederlandsch Lanct, Tweede Serie, 5, pp. 521-533. Anomalies of accomodation and refraction of the eye, Londen. Spierarbeid an warmte-ontwikkeling, in verband met de vereischte voedingsbeginselen, Utrecht.

1971 (1848) De Harmonie van het Dierlijke leven. De Openbaring van Wetten. Een herdruk van de oorspronkelijke uitgave van 1848 , ingeleid door $\mathrm{dr}$. Peter H. Kylstra, Utrecht.

\section{Donders, F.C. \& A.F. Bauduin}

1851 Handleiding tot de natuurkunde van den gezonden Mensch, Dl. I Algemene natuurkunde, Utrecht, Amsterdam.

1853 Handleiding tot de natuurkunde van den gezonden Mensch, DL. II Bijzondere natuurkunde, Utrecht, Amsterdam.

\section{Driesch, $\mathrm{H}$.}

1921 (1909) Philosophie des Organischen, Leipzig.

\section{Duffy, $\mathrm{H}$.}

1993

From Humors to Medical Science. A History of American Medicine. Herziene en uitgebreide uitgave van: The Healers (1976), Chicago.

\section{Ehrenberg, $\mathrm{H}$.}

1956

"Das Verhältnis des Arztes Weizsäckers zur Theologie und das der Theologen zu Weizsäckers Medizin", in: P. Vogel (Hrsg.), 1956. pp. 7-20.

\section{Everts, B.H. \& D.H. van Leeuwen}

1852-53 "Meededelingen en beschouwingen over het krankzinnigenwezen in Engeland", in: Nederlandsch Lancet, 1852-1853, pp. 117 148.

Feinstein, A.R.

1976 (1967) Clinical Judgment, Huntington, New York. 
Festen, $\mathbf{H}$.

1974

125 Jaar geneeskunst en maatschappij: Geschiedenis van de Koninklijke Nederlandse Maatschappij tot Bevordering der Geneeskunst: in opdracht van het hoofdbestuur geschreven ter gelegenheid van het 125 -jarig bestaan der Maatschappij. Utrecht.

\section{Fischer, F.P. \& G. ten Doesschate}

1958

Franciscus Cornelis Donders, Assen.

Fischer-Homberger, E.

1977

Geschichte der Medizin, Berlin, Heidelberg, New York.

Galaty, D.H.

1974

"The philosophical basis of mid-nineteenth century German reductionism", in: Journal of the History of Medicine, 29, pp. 295-316.

\section{Geuns, J. van}

1847

Inwijdings-rede over de geneeskunde als eene zelfstandige natuurwetenschap, gehouden den 28sten januarij 1847, Amsterdam.

1857 "Over de nieuwere richtingen in de Geneeskunde", in: Nederiandsch Tijdschrift voor Geneeskunde, 1, pp. 227-255.

Goei, L. de (red.)

1988 In de geest van het lichaam. De geschiedenis van het dualisme van lichaam en geest in de psychiatrie, NcGv-reeks 126, Utrecht.

Goes van Naters, $M$. van der

1995

"Cleveringa (2)", in: NRC Handelsblad, donderdag 1 juni 1995 , Brieven.

Graeff, J. de

1981

"Prof. Dr. A. Querido", in: Nederlandsche Internisten Vereeniging 19311981, Utrecht, pp. 207-209.

Graul, G.

1917

"Ueber die Erkenntnis des Krankheitsgeschehens", in: Deutsche medizinischeWochenschrift, 43, pp. 1541-1542 \& pp. 1567-1568.

\section{Greenhalgh, T.}

1999

"Narrative based medicine in an evidence based world", in: British Medical Journal, 318, pp. 323-325. 
Gregory, F.

1977

Scientific Materialism in Nineteenth Century Germany, Dordrecht.

Griesinger,W.

1972 (1842) "Herr Ringseis und die naturhistorische Schule", in: Wilhelm Griesinger's gesammelte Abhandlungen. Zweiter Band: Verschiedene Abhandlungen, Berlin, pp. 14-67.

Grote, L.R. (Hrsg.)

1923

Die Medizin der Gegenwart in Selbstdarstellungen, Band II, Leipzig.

Gruber, G.B.

1924

"Anpassung und Anpassungskrankheit", in: Münchener medizinische Wochenschrift, 71, pp, 1316-1319.

Hahn, $\mathbf{P}$.

1976

"Die Entwicklung der psychosomatischen Medizin", in: H. Balmer (Hrsg.), 1976, pp. 932-952.

Haldane, J.S.

1923

1931

Mechanism, life and personality; an examination of the mechanistic theory of life and mind, Westport.

The philosophical bosis of biology. Donnellan lectures University of Dublin 1930. London, Aylesbury.

Have, H. ten

1983

1987

Geneeskunde en filosofie: de invloed van Jeremy Bentham op het medisch denken en handelen, Lochem.

"Afscheid van antropologische geneeskunde?", in: Metamedica, 66, pp. 245-259.

Helmholtz, H. (von)

1903 (1877) "Das Denken in der Medizin", in: H. Helmholtz, 1903, pp. $165-$ 190.

1903

Vorträge und Reden, Band II, Braunschweig.

\section{Hertogh, C.M.P.M}

1986

Bachelard en Canguilhem. Epistemologische discontinuitteit en het medisch norm begrip, Amsterdam.

\section{Honigmann, G.}

1913

Aerztiche Lebensfragen und ihre moderne Lösung, Wiesbaden. 
Houwaert, E.S.

1991

De hygiänisten. Artsa, staat en volksgecondheid in Nederland 1840-1890, Proefschrift Rijksuniversiteit Limburg, Maastricht.

Hueppe, F.

1923

"Ergographie”, in: L.R. Grote (Hrsg), 1923, Leipzig.

Jensen, U.J. \& G. Mooney (eds.)

1990

Changing Values in Medical and Health Care Decision Making. Chichester, enz.

Josselin de Jong, R. de

1930 "Donders als patholoog-anatoom", in: Bijdragen uit de geschiedenis det geneeskunde, 10, pp. 53-72.

Kasanmoentalib, S.

1989

De dans van dood an leven. De Gestaltkreis vanViktor von Weizsäcker in zijn wetenschapshistorische en filosofische context, Zeist.

Keppel Hesselink, J.M.

1983 "Opvattingen van enkele antropologisch geneeskundig geïnspireerde artsen over de praktijk", in: Metamedica, 62, pp. 369-381.

Klebs, E.

1887 Die allgemeine Pathologie oder die Lehre von den Ursachen und dem Wesen der Kronkheitsprozesse, Band I, Jena.

\section{Koch, Richard}

1917

1923

1926

Die ärztliche Diagnose. Beitrag zur Kenntnis des ärtlichen Denken, Wiesbaden. Aerztliches Denken.Abhandlungen über die philosophischen Grundlagen der Medizin, München.

"Der Anteil der Geisteswisssenschaften an den Grundlagen der Medizin", in: Archiv für Geschichte der Medizin, 18, pp. 273-301.

\section{Koch, Robert}

1876

Die Aetiologie der Milzbrand-Krankheit, begründet auf die Entwicklungsgeschichte des Bacillus Anthracis, Leipzig.

1878 Untersuchungen über die Aetiologie der Wundinfectionskrankheiten, Leipzig.

1932 (1882) "Die Aetiologie der Tuberculose", ingekorte versie van gelijknamige bijdrage van Robert Koch in het Berliner klinische Wochenschrift van 10 april 1882, in: Münchener medizinische Wochenschrift, 79, pp. 506-509. 
Köhler, W.

1998

"Doel van de geneeskunde raakt op achtergrond", in: NRC Handesblod, 20 juni 1998, p. 51.

\section{Kräupl Taylor, F.}

1979 The concepts of illness, diseose and morbus, Cambridge, enz.

\section{Krafft, F. (Hrsg.)}

1971

Rudolf Virchow. Drie Reden über Leben und Kranksein. Mit einem Nachwort von Walter.F. Hiss, München.

Kraus, Fr.

1919

Allgemeine und spezielle Pathologie des Persons. Klinische Syziologie, Leipzig.

Krehl, L. (von)

1918

Pathologische Physiologie, 9e druk, Leipzig.

1929 (1928) Krankheitsform und Persönlichkeit, Leipzig. In 1928 onder dezelfde titel verschenen in: Deutsche medizinischeWochenschrift, 54, pp. 17451750.

1930 Pathologische Physiologie. Entstehung, Erkennung und Behandlung innerer Krankheiten, Band I, Die Entstehung innerer Krankheiten, 13 e druk, Leipzig.

1931 Pathologische Physiologie. Entstehung, Erkennung und Behandlung innerer Krankheiten, Band II, Die Erkennung innerer Krankheiten, 13e druk, Berlijn.

1933 Pathologische Physiologie. Entstehung, Erkennung und Behandlung innerer Krankheiten, Band III, Die Behandlung innerer Krankheiten, 13e druk, Berlijn.

1939 "Wandlungen der ärztlichen Tätigkeit in 50 Jahren", in:Münchener medizinische Wochenschrift, 86, pp. 987-990.

\section{Kuhn, T.S.}

1962

1971

The Structure of Scientific Revolutions, Chicago.

"Notes on Lakatos", in: R.C. Buck \& R.S. Cohen (eds.), 1971, pp. 137-146.

1974 (1970)a The Structure of Scientific Revolutions, 2e uitgebreide druk, Chicago.

1974 (1970)b "Postscript-1969", in:T.S. Kuhn, 1974 (1970)a, pp. 174-210.

1977 (1973) “Objectivity, Value Judgment, and Theory Choice”, in:T.S. Kuhn, 1977, pp. 320-339.

1977 (1974) “Second Thoughts on Paradigms", in:T.S. Kuhn, 1977, pp. 293319.

1977 The Essential Tension. Selected Studies in Scientific Tradition and Change, Chicago. 
Laage, R.J.Ch.V. ter

1980

Jacques Moleschott: een markante persoonlijkheid in de negentiende eeuwse fysiologie?, Zeist.

Leibbrand, $\mathbf{W}$.

1954

Heilkunde. Eine Problemgeschichte der Medizin, Freiburg.

\section{Leichtman, $\mathbf{M}$.}

1979

Gestalt Theory and the Revolt Against Positivism", in: A.R. Buss (ed.), pp. 47-75.

Lenoir, $T$.

1982

The strategy of Life. Teleology and Mechanics in Nineteenth Century German Biology, Dordrecht, Boston.

\section{Leonides van Praag, I.}

1866

"Onze richting in ons handelen aan het ziekbed", in: Nederlandsch Tijdschrift voor de Geneeskunde, 10. pp. 263-266.

\section{Lichtenthaeler, C.}

1974

Geschichte der Medizin, Köln-Lövenich.

Lieburg, M.J. van

1987

Medische geschiedenis als interdiscipline. Rede uitgesproken bij de aanvaarding van het ambt van hoogleraar in de geschiedenis der geneeskunde aan de faculteit der geneeskunde van deVrije Universiteit te Amsterdam op 5 juni 1987, Amsterdam.

1999

"Kostbaar oud papier", samenvatting van interview in Medisch Contact 27-2-98, in: Medisch Contact 8-1-99, p. 44.

Lotze, R.H.

1842

Allgemeine Pathologie und Therapie als mechanische Naturwissenschaften, Leipzig.

\section{Lubarsch, $\mathbf{O}$.}

1917

"Ueber Aufgaben und Ziele der pathologischen Forschung und Lehre", in: Deutsche medizinischeWochenschrift, 43, pp. 1377-1380.

1919 a "Ursachenforschung, Ursachenbegriff und Bedingungslehre", in: Deutsche medizinische Wochenschrift, 45, pp. 1-4.

1919b "Ursachenforschung, Ursachenbegriff und Bedingungslehre (Schluß aus Nr. 1)", in: Deutsche medizinischeWochenschrift, 45, pp. 3336. 
Mant, D.

1999 "Can randomised trials inform clinical decisions about individual
patients?", in: The Lancet, 353, pp. 743-746.

Martius, F.

1923 "Autoergographie", in: L.R. Grote (Hrsg.), Leipzig, pp. 105-137.

\section{Mayer, C.F.}

1952 "Metaphysical Trends in Modern Pathology", in: Bulletin for History
of Medicine, XXVI, pp. 71-81. Maynard,A. 1997

"Evidence-based medicine: an incomplete method for informing treatment choices", in: The Lancet, 349, pp. 126-128.

\section{Meulen, R.H.J. ter \& C.Widdershoven-Heerding}

1985

"Het fysiologisch ziektebegrip in de vroege Nederlandse psychiatrie. De opvattingen van J.N. Ramaer (1817-1887) over de oorzaken van krankzinnigheid", in: Nieuwe Nederlandse Bijdragen tot de Geschiedenis der Geneeskunde en der Natuurwetenschappen, 13, pp. 110-120.

\section{Mol, A. \& P. van Lieshout}

1989

Ziek is het woord niet. Medicalisering, normalisering en de veranderende taal van huisartsgeneeskunde en geestelijke gezondheidszorg, 1945-1985, Nijmegen.

\section{Moleschott, J.}

1989 (1856) "Licht en leven. Redevoering bij de aanvaarding van het opentlijk leeraarsambt, tot navorsching van de natuur des menschen, aan de hoogeschool van Zürich", in: J. Moleschott, 1989, pp. 52-70.

1989 (1862) "Iets over de methode van het physiologische onderzoek. Redevoering ter aanvaarding van het hoogleeraarsambt in de physiologie aan de hoogeschool van Turijn, vertaald uit het Hoogduitsch door Corstiaan de Jong", in: J. Moleschott, 1989. pp. 71-86.

1989 Jacobus Moleschott. De eenheid des levens. Uitgegeven, ingeleid en van aantekeningen voorzien door V.J.B.M. Peeters, Baarn.

\section{Moulin, D. de (red.)}

Kracht en Stof. De introductie van moderne natuurwetenschappelijke denkwijzen in de geneeskunde, zoals blijkt uit de Nederlandse medische vakbladen, 1840-1870, Amsterdam. 
Müller, $\mathrm{F}$.

1932

Müller, Joh.

1833

1834

1838

1840

Müller, $\mathbf{M}$.

1926

Mulder, G.J.

1842

Over de waarde der natuurkundige wetenschappen voor de geneeskunde; uitgesproken bij de opening der scheikundige lessen aan de Utrechtse Hoogeschool 1842, Rotterdam.

Naunyn, B.

1869

Neve, $M$.

1995

Pagel,W.

1931

Virchow und die Grundlagen der Medizin des XIX. Jahrhunderts, Jena.

\section{Pellegrino, E. D. \& D.C. Thomasma}

1981

A philosophical basis of medical practice. Toward a philosophy and ethic of the healing professions, New York, Oxford.

Plessner

1928

Die Stufen des Organischen und der Mensch, Berlijn.

Poggi, S. \& M. Bossi (eds.)

1994

Romanticism in science: science in Europe 1790-1840, Dordrecht, Boston, London.

Puff, E.

1950 Materialien zur Wandlung des Krankheitsbegriffes seit Virchow, Inaugural-

Dissertation, Münster. 
Querido, A.

1935

1947

$1948 a$

$1948 b$

$1948 c$

1949

1964

1966

1980

1983

1990

1994

Vitamin D requirements in relation tot Calcium and Phosphorus content in the diet, Amsterdam.

"Hirsutisme, vetzucht, menstruatiestoornissen en bijnierexploratie, gevolgd door discussie", in: Nederlandsch Tijdschrift vor Geneeskunde, 91, pp. 3104-3113.

"Enige aspecten der klinische endocrinologische diagnostiek I", in: Het Hormoon, 12, no. 9. pp. 154-166.

"Enige aspecten der klinische endocrinologische diagnostiek II", in: Het Hormoon, 13, no. 3, p. 39-51.

De betekenis van de pathologische physiologie voor de geneeskunde. Rede uitgesproken bij de aanvaarding van het ambt van Hoogleraar aan de Rijksuniversiteit te Leiden opVrijdag 22 October 1948, Leiden.

"Diagnostiek van ziekten der bijnierschors", in: Nederlandsch Tijdschrift woor Geneeskunde, 93, pp. 3391-3400.

"Thoughts on the teaching of basic sciences in relation to education for medical practice", in: Medical Education, Boerhaave course, Leyden 16-19 september 1964, pp. 15-20.

Aan de start. Rede gehouden op 7 oktober 1966 ter gelegenheid van de opening van de Medische Faculteit Rotterdam, Rotterdam.

"Het natuurlijk beloop van ziekte", in: A. Querido \& J. Roos (red.), 1980, pp. 3-13.

Het is de schuld van Napoleon. Afscheidscollege op vrijdag 25 maart 1983 aan de Rijksuniversiteit Leiden, Leiden.

De binnenkant van de geneeskunde. Een autobiografie opgetekend in samenwerking met Jacky Bax en Ruud Overdijk, Amsterdam.

"Introduction to the First Day: Emerging Concepts", in: A. Querido et al. (eds.), 1994, p. 3-9.

\section{Querido, A (coordinating editor), L.A. van Es and E. Mandema (editors)}

1994

The Discipline of Medicine: emerging concepts and their impact upon medical research and medical education, Amsterdam, enz.

\section{Querido, A. \& J. van Gijn}

1994

"'The Wisdom of the body': the Usefulness of Systems Thinking for Medicine", in: A. Querido et al. (eds.), 1994, p. 67-78.

\section{Querido, A \& L.G. Huis in 't Veld}

1947

"De betekenis voor de kliniek van het onderzoek naar het gehalte aan neutrale 17-ketosteroiden in de urine", in: Nederlandsch Tijdschrift voor Geneeskunde, 91, pp. 3255-3261. 


\section{Querido, A. \& J. Lubsen}

1980

Principes van klinisch denken an handelen. Nederlandse bewerking van H.R. Wulff, 1976, Utrecht.

\section{Querido, A \& B. Rexed}

1967

Rede's uitgesproken door Prof. dr.A. Querido op 18 september 1967 ter gelegenheid van de opnening van het Academisch jaar van de Medische faculteit Rotterdam en de Nederlandse Economische Hogeschool, Rotterdam.

\section{Querido, A. \& J. Roos}

1980

Controversen in de geneeskunde, I en II, Utrecht

Rad, M. von (Hrsg.)

1984

Anthropologie als Thema von psychosomatische Medizin und Theologie, Stuttgart, enz.

Ramaer, J.N.

1841

"Over de aanwending van het mikroskoop tot geneeskundig onderzoek", in: Archief voor de Geneeskunde, 1, pp. 305-368.

$1844 \mathrm{a}$ Blik op de dierlijke vermogens en derzelver betrekking tot de ziel, Rotterdam.

$1844 \mathrm{~b}$

1846 "Over het begrip van specifieke geneesmiddelen", in: Archief voor de Geneeskunde, 4, pp. 1-76.

Een woord aan Nietgeneeskundigen over krankzinnigheid en krankzinnigenbehandeling; in twee voorlezingen, uitgesproken in het genootschap ter beoefening van natuurkundige wetenschappen te Zutphen, en met aanteekeningen uitgegeven, Rotterdam.

1850 "Anatomico-pathologische aanteekeningen, de hersenen en hare bekleedselen betreffende. 1. Over ecchymoses subarachnoideae", in: Tijdschrift der Nederlandsche Maatschappij tot Bevordering der Geneeskunst, 1, tweede afdeeling, pp. 69-97.

1851a "De geneeskunde als stellige wetenschap", in: Tijdschrift der Nederlandsche Maatschappij tot Bevordering der Geneeskunst, 2, tweede afdeeling, pp. 3-30.

$1851 \mathrm{~b} \quad$ "Over de verwerping van het begrip ontsteking", in: Tijdschrift der Nederlandsche Maatschappij tot Bevordering der Geneeskunst, 2, tweede afdeeling, pp. 130-150.

1852 Dronkenschap en krankzinnigheid; ene voorlezing, Tiel.

1855 "Over de apoplexie als oorzaak van krankzinnigheid", in: Nederlandsch Tijdschrift voor Geregtelijke Geneeskunde an voor Psychiatrie, 2, pp. 69-159. 
"Brieven over de behandeling der krankzinnigen voor hunne plaatsing in de gestichten", in: Noderlandsch Tijdschrift vor de Geneeskunde, 1. pp. 113-123.

\section{Rather, L.J.}

1971 (1958) "Introduction: Harvey, Virchow, Bernard, and the methodology of science", in: L.J. Rather (ed.), 1971 (1958), pp. 1-25.

Rather, L.J. (ed.)

1971 (1958) Disease, Life, and Man. Selected esays by RudolfVirchow, translated and with an introduction by Lelland J. Rather, Stanford.

\section{Ribbert, $\mathbf{H}$.}

1899

1917

Die Lehren vomWesen der Krankheiten in ihrer geschichtlichen Entwicklung, Bonn.

"Die Konstitution der Menschheit", in: Deutsche medizinische

Wochenschrift, 43. pp. 1609-1612.

Riese, $\mathbf{W}$.

1953

The conception of disease, its History, its Versions and its Nature, New York.

\section{Ringer, F.K.}

1969

The decline of the German mandarins: The German academic community, 18901933, Cambridge (Mass.).

Rössler, D.

1959

"Krankheit und Geschichte in der antropologioschen Medizin (Richard Siebeck und Viktor von Weizsäcker)", in: P. Christian \& D. Rössler (Hrsgs.), 1959, pp. 165-180.

\section{Romein, J. \& A.}

1956

Erflaters van onze beschaving. Nederlandse gestalten uit zes eeuwen,

Amsterdam, Antwerpen.

\section{Romein, A.}

1956 (1938-1940) 1940) pp. 677-700.

\section{Root, J.M.H., op 't}

1984 "Als je leven zoekt". Gezondheid en genezen in antropologisch perspektief: Joodse traditie als levensoriēntatie, Proefschrift Rijksuniversiteit Limburg, Maastricht. 
Rooymans, H.G.M.

1981

"De betekenis van het werk van H.C. Rümke voor de huidige psychiatrie", in: H.C. Rümke, 1981, p.11-29.

\section{Rosenzweig, $\mathrm{F}$.}

1979

Brifée und Tagebücher, Band 2, Den Haag.

Roser, W. \& C.A.Wunderlich,

1975 (1842) "Ueber die Mängel der heutigen deutschen Medicin und über die Nothwendigkeit einer entschieden wissenschaftlichen Richtung in derselben", in: K.E. Rothschuh (Hrsg.), 1975, pp. 4571.

\section{Rothschuh, K.E.}

1968a

"Friedrich Oesterlen (1812-1877) und die Methodologie der Medizin", in: Sudhoffs Archiv, 52, pp. 97-129.

1968b Physiologie. DerWandel ihrer Konzepte, Probleme und Methoden vom 16.-19. Jahrhundert, Freiburg, München.

1973 (1953) History of Physiology, Vertaald en uitgegeven met een nieuwe Engelse bibliografie door G.B. Risse, Huntington, New York.

1975

1978 "Einleitung", in: K.E. Rothschuh (Hrsg.), 1975, pp. 1-7. Konzepte der Medizin in Vergangenheit und Gegenwart, Stuttgart.

\section{Rothschuh, K.E. (Hrsg.)}

1975

Was ist Krankheit, Darmstadt.

\section{Rümke, H.C.}

Phaenomenologische en klinisch-psychiatrische studie over geluksgevoel, Leiden. Ontwikkelingspsychologie en psychotherapie. Rede uitgesproken bij de aanvaarding van het ambt van bijzonder hoogleeraar in de ontwikkelingspsychologie vanwege het Utrechtsche Universiteitsfonds aan de Rijksuniversiteit te Utrecht op 19 juni 1933. Amsterdam.

Psychiatrie als geestes- en natuurwetenschap, Rede uitgesproken bij de aanvaarding van het ambt van hoogleeraar in de faculteit der generskunde aan de Rijksuniversiteit te Utrecht op 8 maart 1937. Utrecht.

Studies en voordrachten over psychiatrie, tweede vermeerderde druk, Amsterdam.

1948 (1922) "Iets over de phaenomenolgische methode en haar toepassing in de klinische psychiatrie. Een bijdrage tot de phaenomenologie van de betrekkingswaan", in: H.C. Rümke, 1948, pp. 88-99. 
1948 (1932) "Over klinische psychiatrie, (Nosologische eenheid, (Kraepelin), rubriek, diagnose)". in: H.C. Rümke, 1948, pp. 17-27.

1953 Nieuwe studies an voordrachten over psychiatric, Amsterdam.

1953 (1952) "De betrekkelijkheid van de psychiatrische diagnose", in: H.C. Rūmke, 1953, pp. 114-124.

1954 Een blociende psychiatrie in gevaar, Rede ter gelegenheid der viering van den 318 den dies natalis der Rijksuniversiteit te Utrecht gehouden door den rector magnificus Dr. H.C. Rümke op 26 maart 1954 in de Domkerk, Utrecht

1958a Derde bundel studie en voordrachten over psychiotrie, Amsterdam.

1958 (1955) "Beschouwingen over de overgangen tussen gezond en ziek. (Het probleem der zgn. "vloeiende overgangen".)", in: H.C. Rümke, 1958a, pp. 166-172.

1958 (1957) "De ontwikkeling der psychiatrie in het tijdvak 1907-1957", in: H.C. Rümke, 1958a, pp. 195-236.

1958b "Over gronden van zekerheid in de wetenschap. (Gronden van zekerheid in de psychiatrie.)", in: H.C. Rümke, 1958a, pp. 6279.

1963 Op de drempel. Jongst verieden an tockomst van de psychiatric. Afscheidscollege gehouden in de Domkerk te Utrecht op 30 mei 1963, Amsterdam.

1964 (1929) Inleiding in de karakterkunde, vijfde herziene druk, Haarlem.

1981 Vorm en inhoud. Een keuze uit de essays van H.C. Rümke door prof. dr. S.J. Nijdam en prof. dr. H.G.M. Rooymans, Utrecht.

Sackett, D.L. ,W.M.C. Rosenberg, J.A.M. Gray, R.B. Haynes, W.S. Richardson 1996

"Evidence based medicine: what it is and what it isn 't", in: British Medical Journal, 312, pp. 71-72.

\section{Sborowitz, A. (Hrsg.)}

1979 (1969) Der Leidende Mensch. Personale Psychotherapie in anthropologischer Sicht, Sammelbuch inVerbindung mit Ernst Michel herausgegeben, Darmstadt.

\section{Scheler, M,}

1928

Die Stellung des Menschen im Kosmos, Darmstadt.

\section{Schipperges, $\mathrm{H}$.}

1977

"Einheitsbestrebungen und Normbegriff auf der Naturforscher versammlung im 19. Jahrhundert", in: Sudhoffs Archiv, 61, pp. 313330. 


\section{Schneevoogt, G.E.V.}

1868

"Over den ontwikkelingsgang en de omvang der hedendaagsche psychiatrie, alsmede over de mate van psychiatrische kennis, die tegenwoordig van alle geneeskundigen gevorderd moet worden. Openingsrede, gehouden bij de hervatting der lessen over psychiatrie en neuro-pathologie aan het Atheneum illustre te Amsterdam, op den 20sten januarij 1868", in: Nederlandsch Tijdschrift voor Geneeskunde, 10, pp. 159-174.

\section{Schroeder van der Kolk, J.L.C.}

1835

Eene voorlezing over het verschil tusschen doode natuurkrachten, levenskrachten en viel, Utrecht.

Schwann, Th.

1910 (1839) Mikroskopische Untersuchungen über die Uebereinstimmung in der Struktur und dem Wachstume der Tiere und Pflanzen, Leipzig.

\section{Schwarz, 0.}

1925

1929

1933
Psychogenese und Psychotherapie körperlicher Symptome, Wenen.

"Sexualpathologie als Problem einer medizinischer

Anthropologie", in: Deutsche medizinischeWochenschrift, 55, pp. 1619 1621.

"Über Wesen und Aufgabe einer medizinischen Anthropologie", in: Th. Brugsch (Hrsg.), 1933, pp. 84-94.

\section{Schweninger, $\mathrm{E}$.}

1906

Der Artt, Frankfurt am Main.

\section{Siebeck, R.}

1929

$1931 \mathrm{a}$

$1931 \mathrm{~b} \quad$ "Pathologische Physiologie und Klinik. Ludolf Krehl zum 70. Geburtstag am 26. XII. 1931" in: Deutsche medizinischeWochenschrift, 57. pp. 2169-2172.

1932 "Konstitution und Krankheitsverlauf", in: Münchener medizinische Wochenschrift, 79, pp. 1263-1266.

1949 Medizin in Bewegung. Klinische Erkenntnisse und ärztliche Aufgabe, Stuttgart. 1954 Die Wirklichkeit im ärztlichen Denken", in: Deutsche medizinische Wochenschrift, 79, pp. 316-318. 
Snellen, H., S. Talma, Th. H. Mac Gillavry, W. Einthoven, T. Place, B.J. Stokvis (Commissie van Redactie)

1888

Feestbundel aan Franciscus Cornelis Donders op den 27 sten Mei 1888 aangeboden door het Nederlandsch Tijdschrift voor Geneeskunde, Amsterdam.

\section{Stenvers sr., H.W.}

1955

"Winkler als neuroloog. Rede, gehouden bij de 100 e verjaardag van Prof. dr. C.Winkler op vrijdag 25 februari 1955", in: Nederlandsch Tijdschrift voor Geneeskunde, 99, pp. 632-642.

Stokvis, B.J.

1901

"Virchow und die niederlândische Medicin", in: Berliner klinische Wochenschrift, 41, pp. 1038-1042.

Straus, E.

1926

"Das Problem des Individualităt", in: Th. Brugsch \& F.H. Lewy (Hrsgs.), 1926, pp. 25-134.

\section{Temkin, $\mathbf{O}$.}

1946

"Materialism in French and German physiology of the early nineteenth century", in: Bulletin for History of Medicine, 20, pp. 322 327.

\section{Tendeloo, N. Ph.}

1922

Grondbeginselen der algemeene ziektekunde, Groningen, Den Haag.

\section{Theunissen, $\mathbf{M}$.}

1977

Der Andere: Studien zur Sozialontologie der Gegenwart, tweede uitgebreide druk, Berlijn, New York.

\section{Thung, P.J.}

1984

"De anthropologie van de jaren dertig tot vijftig en de grondslagen der geneeskunde", in: Metamedica, 63, pp. 165-180.

\section{Uexküll, J. von}

1928

Theoretische Biologie, tweede gewijzigde druk, Berlijn.

\section{Valkenburg, C.T. van}

1955

\footnotetext{
"Winkler als Psychiater. Rede gehouden op 25 februari 1955 in een bijeenkomst der Nederlandsche Vereeniging voor Psychiatrie en Neurologie en de Amsterdamsche Neurologen Vereeniging", in: Nederlandsch Tijdschrift voor Geneeskunde, 99, pp. 643-647.
} 


\section{Verbrugh, H.S.}

1983

Bij het afscheid van prof. dr. A. Querido (Leiden) "eigenlijk heb ik een paar levens geleid. ... en over elk daarvan zou een roman te schrijven zijn". in: NRC Handelsblad, 24 maart 1983, Wetenschap \& onderwijs, p. 3.

Verwey, G.

1980

1984

1985

1986

1988

1990

Psychiatrie tussen antropologie en natuurwetenschap. Een historische studie over het zelfbegrip van de Duitse psychiatrie van ca. 1820 tot ca. 1870, Meppel. "Het antropologische in antropologische geneeskunde", in: Metamedica, 63, pp. 45-56.

Psychiatry in an Antropological and Biomedical Context. Philosophical Presuppositions and Implications of German Psychiatry, 1820-1870, Dordrecht, Boston, Lancaster.

"Claude Bernard in het licht van de hedendaagse holismereductionisme discussie", in: Scripta medico-philosophica, schrift 1 , pp. 42-61.

"Dualismen in de geschiedenis van de psychiatrie; een casus: de Heidelberger psychiatrie in het interbellum", in: L. de Goei (red.), 1988, pp. 58-87.

"Psychiatrie, fenomenologie en het primaat van de klinische ervaring (1900-circa 1925)", in: Tijdschrift voor psychiatrie, 32, pp. 693-704.

\section{Vidoni, $\mathrm{F}$.}

1991

Ignorabimus! Emil Du Bois-Reymond und die Debatte über die Grenzen wissenschaftlicher Erkenntnis im 19. Jahrhundert. Met een voorwoord door Ludovico Geymonat, Frankfurt am Main.

\section{Virchow, R.} Archiv für pathologische Anatomie und Physiologie und für klinische Medicin, I, pp. 3-19.

Die Einheitsbestrebungen in der wissenschaftlichen Medicin, Berlijn. Johannes Müller. Eine Gedächtnissrede, gehalten bei der Todtenfeier am 24. Juli 1858, Berlijn.

"Ueber die Standpunkte in der wissenschaftliche Medicin", in: Archiv für pathologische Anatomie und Physiologie und für klinische Medicin, LXX, pp. 1-10. des med.-chirurg. Friedrich-Wilhem-Instituts, Berlijn. 
1971 (1858) "Ueber die mechanische Auffassung des Lebens", in: F. Krafft (Hrsg.), 1971, pp. 7-32.

1971 (1859) "Atome und Individuen. Vortrag, gehalten im wissenschaftlichen Vereine der Singakademie zu Berlin am 12. Februar 1859", in: F. Krafft (Hrsg.). 1971, pp. 35-67.

1975 (1869) “Ueber die heutige Stellung der Pathologie", in: K.E. Rothschuh, (Hrsg.), 1975, pp. 72-91.

\section{Vogel, P. (Hrsg.)}

1956 Viktor vonWeissäcker - Arzt im Irrsal der Zeit. Fine Freundesgabe zum siebrigsten geburtstag am 21.4.1956, Göttingen.

\section{Weizsäcker, V. von}

1926

1931

1935

$1947 \mathrm{a}$

$1947 b$

1949

1951

1955 (1951) De zieke mens, Nederlandsche vertaling door R. de Jong-Belinfante van V. von Weizsäcker, 1951, Amsterdam.

1955 (1954) Natur und Geist. Erinnerungen eines Artes, Göttingen.

1957 "Einführung des Subjekts", in: Deutsche medizinischeWochenschrift, 83 , pp. 924-928.

1967 (1956) Pathosophie, Göttingen.

1975 (1927) "Der Arzt und der Kranke", in: K.E. Rothschuh (Hrsg.), 1975. pp. 214-232.

1980a "Krankengeschichte", in:W. Bräutigam (Hrsg.), 1980.

(1927/28) pp. 11-31.

$1980 \mathrm{~b}$ (1948) "Grundfragen medizinischer Anthropologie", in: W. Bräutigam (Hrsg.), 1980, pp. 319-348.

Weve, H.J.M. \& G. ten Doesschate

1935

Die Briefe Albrecht von Groefe's an F.C. Donders (1852-1870), Stuttgart. 


\section{Widdershoven-Heerding, $\mathrm{C}$.}

1987

1990 Medicine, 8, pp. 179-185.

"Medicine as a Form of Practical Understanding", in: Theoretical "The Place of Values in Health Care: Recurring Themes in the Philosophy of Medicine", in: U.J. Jensen \& G. Mooney (eds.), 1990, pp. 53-60.

\section{Wiersma, E.D.}

1932

"Clinische lessen; iets over ziekte", in: Nederlandsch Tijdschrift voor Geneeskunde, 76, pp. 2594-2604.

Winkler, C.

1893

1896a

$1896 \mathrm{~b}$

1909

1912

1918-1933

1915

1917

$1918-1933$

1925
De beteekenis van het onderwijs in de psychiatrie voor de geneeskunde. Redevoering bij de anvaarding van het Hoogleraarsambt aan de Rijks-Universiteit te Utrecht den 20sten september 1893 uitgesproken door Dr. C.Winkler, Utrecht.

Over de doelmatige beweging in de natuur. Redevoering bij de aanvaarding van het Hoogleeraarsambt aan de Universiteit van Amsterdam den 5 den october uitgesproken door Dr. C.Winkler, Hoogleeraar in de klinische neuropathologie en psychiatrie, Utrecht.

Het onderwijs in psychiatrie in Nederland gedurende de laatste vijfentwintig jaren. Rede uitgesproken op 17 november 1896 te Utrecht bij de opening der feestvergadering ter eere van het 25 jarig bestaan derVereeniging ter bevordering der Psychiatrie, door Dr. C.Winkler, Hoogleeraar te Amsterdam, Haarlem.

"Over de beteekenis van Instituten voor Hersenonderzoek", in: Toespraken gehouden bij de opening van het Centraal Instituut voor hersenonderzoek op dinsdag 8 juni 1909, pp. 19-27.

De relatieve waarde van het localisatie-principe. Een bijdrage tot de ontwikkeling der geneeskunde in het einde der $19 \mathrm{de} e \mathrm{n}$ in het begin der 20 ste eeuw. Rede ter gelegenheid van den dies natalis der Universiteit van Amsterdam. Uitgesproken op 8 januari 1912 door den Rector-Magnificus Dr. C.Winkler, Haarlem.

"Travail cérébral et volonté", in: C. Winkler, 1918-1933. pp. 489-505.

De verhouding der psychologie tot de physiologie van het zenuwstelsel. Rede uitgesproken bij de aanvaarding van het Hoogleeraarsambt aan de Rijks-Universiteit te Utrecht, op Maandag 1 Februari 1915, Utrecht.

Handbock der neurologie Eerste gedeelte. De bouw van het zenuwstelsel, Haarlem. Opera omnia,V,Amsterdam, 1909-1913. Utrecht, 1913-1918, Haarlem.

De toekomst der psychiatrie. Afscheidsles gegeven op zaterdag 20 juni 1925 bij het neerleggen van zijn ambt als hoogleruar in de psychiatrie en neurologie aan de Rijks-universiteit te Utrecht, Haarlem. 
"Het 'localisatie-probleem' en de hedendaagsche psychiatrie", in: Nederlandsch Tijdschrift voor Geneskunde, 73, pp. 1808-1823.

1947 Herinneringen van Cornelis Winkler 1855-1941, Arnhem.

Woodward, W.R.

1975

The medical realism of R. Hermann Lotze, Yale University Ph. D., New Haven.

\section{Woodward,W.R. \& R. Pester}

1994

"From Romantic Naturphilosophie to a Theory of Scientific Method for the Medical Disciplines", in: S. Poggi \& M. Bossi (eds.), 1994, pp. 161-173.

\section{Wulff, H.R.}

1976 Rational Diagnosis and Treatment, Oxford, enz.

1994 "The Disease Concept and the Medical View of Man", in:
A. Querido et al., 1994, pp. 11-19.

\section{Wunderlich, C.A.}

1861 (1858) Geschiedenis der Geneeskunde, Tiel.

\section{Wyss. D}

1979 (1969) "Person und Begegnung in der Anthropologie Viktor von Weizsäckers", in: A. Sborowitz (Hrsg.), 1979 (1969), pp. 238258.

\section{Zwaardemaker, $\mathrm{H}$.}

1910 De jongste gestalte der physiologie. Rede uitgesproken op den 274sten gedenkdag van de Stichting der Utrechtsche Hoogeschool, den 17en maart 1910 door den Rector-Magnificus, Haarlem. 



\section{Personenregister}

Achilles, P. 143.

Ackerknecht, E.H. 23, 24, 38, 48.

Albright, F. (1900-1969) 169.

Apel, K.-O. 9, 176.

Aschoff, L. (1866-1942) 96-97, 103.

Baier, H. 127.

Balen, G.F. van 99.

Barge, J.A.J. (1884-1952) 5, 86, 106. 116-125.

Barth, K. (1886-1968) 127.

Bauduin, A.F. 72-73, 75, 81.

Belzen, J.A. van 115, 157-158, 163.

Benton, E. 28, 31.

Berg, J.H. van den (*1914) 163.

Berg, M. 183.

Bergmann, G. von (1878-1955) 96, 104.

Bernard, C. (1813-1878) 21, 24-29, 33-34, 41, 43, 48-53, 64, 85, 170.

Bernstein, R.J. 15-18, 176, 180, 185.

Bichat, F.X. (1771-1802) 24, 28.

Bieganski, W. (1857-1917) 89, 94-95, 100-102.

Bier, A. (1861-1949) 102.

Binswanger, L. (1881-1966) 63.

Bleker, J. 34, 39.

Bleuler, P.E. (1857-1939) 157.

Boerhaave, H. (1668-1738) 24.

Bois-Reymond, E. du (1816-1898) 21, 27, 29-31, 35-36, 45-46, 71, 99 , 113.

Bolk, L. (1866-1930) 116.

Bom, Th. van der 84 .

Bonah, C. 0. 22.

Boorse, C. 183.

Bouman, K.H. (1874-1947) 156-157.
Bouman, L. (1869-1936) 115, 156 157.

Bräutigam, W. 154.

Brūcke, E. (1819-1892) 21, 27, 31.

Brugsch, Th. (1878-1963) 96, 129 130,133

Bruna, M. 84, 156.

Buber, M. (1878-1965) 128, 141, 152.

Burckhardt, R. 131.

Burger, H. (1864-1957) 83, 98-99, 102-103, 105-106.

Buytendijk, F.J.J (1887-1974) 127. 163.

Canguilhem, G. 10-12, 41 .

Cannon, W.B. (1871-1945) 127.

Cassirer, E. 23.

Christian, P. 137, 146.

Collingwood, R.G. 9.

Conrad, L.I. 6-7.

Cranefield, P.F. 9, 69.

Darwin, Ch. (1809-1882) 70.

Deen, I. van, (1805-1869) 22, 70.

Dekkers, W.J.M. 127.

Derksen, A.A. 14-15.

Descartes, R. 35, 136.

Diepgen, P.39, 87, 89-90.

Dierickx, K. 182.

Dillmann, R.J.M. 182.

Dilthey, W. (1833-1911) 9, 159.

Doesschate, G. ten 69-70, 74.

Donders, F.C. (1818-1889) 5, 21, 56, 57, 67-77, 81, 99, 107.

Dray, W. 9.

Driesch, H. (1867-1941) 81 .

Duffy, H. 22. 
Ehrenberg. H. (1883-1958) 127.

Everts, B.H. 68.

Feinstein, A.R. 183.

Festen, H. 57-58.

Fischer, F.P. 69-70, 74.

Fischer-Homberger, E. 21.

Foucault, M. 12.

Freud, S. (1856-1939) 115.

Gadamer, H.-G. 180.

Galaty, D.H. 9, 30.

Geuns, J. van (1808-1880) 22, 24, 42 , $51,55$.

Gijn, J. van 174.

Goes van Naters, M. van der 116.

Goethe, J.W. (1749-1832) 30.

Graefe, A. von (1828-1870) 70.

Graeff, J. de 168 .

Graul, G. 90-91.

Greenhalgh, T. 187.

Gregory, F. 9, 30, 32.

Griesinger,W. (1817-1868) 21, 27, 34 . $40,57,64,66,181$.

Groen, J. (1903-1990) 163.

Gruber, G.B. 96.

Haldane, J.S. (1860-1936) 81-82, 131.

Have, H. ten 7, 156.

Heidegger, M. (1889-1976) 141.

Helmholtz, H. (von) (1821-1894) 21, 26-27, 31-32, 36, 49-52, 71.

Hempel, C. 9.

Henle, J. (1809-1885) 21, 27, 41, 62. 71.

Hertogh, C.M.P.M. 10.

Honigmann, G. (1863-1930) 86, 105.

Horst, L. van der 163.

Houwaert, E.S. 8.

Hueppe, F. (1852-1913) 89-91, 129.

Huis in 't Veld, L.G. 169.

Humboldt, W, von (1767-1835) 135.

Husserl, E. (1859-1938) 159.
Jansen, B.C.P. (1884-1962) 167.

Jaspers. K. (1883-1969) 109, 115 ,

127, 158-159, 163.

Jongh, S.E. de 167.

Jordan, H.J. (1877-1943) 120-122.

Josselin de Jong, R. de 76.

Kasanmoentalib, S. 9, 127, 135-136.

Keppel Hesselink, J.M. 130.

Klebs, E. (1834-1913) 87.

Koch, Richard 86, 105, 128, 146-147.

Koch, Robert (1843-1910) 87, 90.

Köhler, W. 168.

Kraepelin, E. (1856-1926) 158.

Krafft, F. 43.

Kräupl Taylor, F. 4, 44.

Kraus, Fr. (1858-1936) 85, 129-131.

Krehl, L. (von) (1861-1937) 94, 129.

131-133, 135, 138-141, 147-149.

Kronfeld, A. (1886-1941) 158-159.

Kuenen, W.A. 167-168.

Kuhn, T.S, 14-18, 180, 185.

Laage, R.J.Ch.V. ter 74.

Laennec, R.Th.H. (1781-1826) 49.

Leeuwen, D.H. van 68.

Leibbrand, W. 135.

Leichtman, M. 84, 126.

Lenoir, T. 28, 31-32.

Leonides van Praag, I. 54-55.

Lewy, F.H. 130.

Lichtenthaeler, C. 21, 25.

Lieburg, M.J. van 7-8, 10.

Lieshout, P. van 11-13.

Lipps, Th. (1851-1914) 159.

Lotze, H. (1817-1881) 21, 31, 34, 41.

Lubarsch, O. (1860-1933) 92-93, 95.

Lubsen, J. 172.

Ludwig, C. (1816-1895) 22, 27,69. 71.

Lwoff, A.M. 167. 
Maeder, A. (1882-1971) 157.

Magendie, F. (1783-1855) 28.

Mandema, E.

Mant, D. 187.

Marchand, F. (1846-1928) 94, 131.

Martius, Fr. (1850-1923) 89-90, 92 -

93, 129.

Mayer, C.F. 83.

Mayer, R. (1814-1878) 73.

Maynard, A. 187.

Merleau-Ponty, M. 127.

Mettrie, J. Offray de La (1709-1751) 35-36.

Meulen, R.H.J. ter 64, 115, 157.

Mol, A. 11-13.

Moleschott, J. (1822-1893) 21-23, 33 , $70,74$.

Moulin, D. de 9.

Mulder, G.J. (1802-1880) 69, 71.

Mulder, J. 168.

Müller, F. 133.

Müller, Joh. (1801-1858) 22, 28, 30-

$33,36-37,71$.

Müller, M. 30-31.

Naunyn, B. (1839-1925) 21, 25.

Neve, M. 184.

Pagel, W. 39, 42.

Paracelsus (1493-1541) 39.

Paulsen, Fr. (1846-1908) 84.

Peeters, V.J.B.M. 74.

Pellegrino, E.D. 4-5.

Pester, R. 24, 28.

Pinel, Ph. (1745-1826) 49.

Plessner, H. (1892-1985) 127.

Popper, K.R. 17.

Puff, E. 94.

Querido, A. $\left({ }^{* 1912)}\right.$ 5, 167-174.

Ramaer, J.N. (1817-1887) 5, 21, 5668, 77.

Rather, L.R. 24, 38, 44.

Reinhardt, 48.

Rexed, B. 169.
Ribbert, H. (1855-1920) 42, 94-95.

Riese, W. 4, 39, 44.

Rijnberk, G. van (1875-1953) 156.

Ringer, F.K. 126.

Ringseis, J.N. von (1785-1880) 34.

Rogers, C.R. (1902-1987) 163.

Rokitansky, C. (1808-1878) 24,47, 57.

Romein, A. 56, 74.

Romein, J. 56.

Root, J.M.H., op 't 128

Rooymans, H.G.M. 164.

Rosenzweig, F. (1886-1929) 128, 141.

Roser, W. (1817-1888) 39-40, 57, 6061,64 .

Rôssler, D. 140.

Rothschuh, K.E. 3-4, 21-23, 28, 30$32,48,53,176$.

Rümke, H.C. (1893-1967) 5, 156-167.

Sackett, D.L. 186.

Scheler, M. (1874-1928) 127, 141 , 149, 157-158.

Schelling, F.W.J. von (1775-1854) 30 .

Schipperges, H. 37.

Schneevoogt, G.E.V. (1814-1871) 65.

Schönlein, J. L. (1793-1864) 34, 40.

Schroeder van der Kolk, J.L.C (17971862) $69,74$.

Schwann, Th. (1810-1882) 21, 27, 3132.

Schwarz, O. (1883-1949) 131, 133135.

Schweninger, E. (1850-1923) 86, 105. Sherrington, Ch.S. (1857-1962) 111. Siebeck, R. (1883-1965) 95, 125, 127 . $131,133,135,140-141,149-151$. Skoda J. (1805-1881) 24, 57.

Snellen, H. 69.

Stenvers sr., H.W. 108.

Stokvis, B.J. (1834-1902) 38.

Straus, E. (1891-1975) 126.

Sydenham, I. (1624-1689) 49. 
Talma, S. 107.

Temkin, O. 28-29, 32.

Tendeloo, N.Ph. (1864-1945) 81, 96.

Theunissen, M. 128, 152.

Thomasma, D.C. 4-5.

Thung, P.J. 156.

Uexküll, J. von (1864-1944) 81.

Valkenburg, C.T. van 108.

Verbrugh, H.S. 167.

Verwey, G. 9, 22-23, 29-30, 37, 66, 82 . $126-127,137,144,159$.

Vidoni, F. 9, 32, 35.

Virchow, R. (1821-1902) 21, 24-27, $30,34-35,37-39,41-45,47-50,53$, $57,62,64-65,75,80,88-89,93-$ $94,181$.

Wagner-Jauregg, J. (1857-1940) 107. Weber, E.H. (1795-1878) 28, 30.

Weber, M. 9.

Weizsäcker, V. von (1886-1957) 2 ,

$127-128,131,133,135-137,140$ 144, 151-154, 163.

Weve, H.J.M. 70.

Widdershoven-Heerding, C. 64, 92 . 182.

Wiersma, E.D. 106.

Winkler, C. (1855-1941) 5, 86, 106$116,157,162$.

Wittig. J. (1879-1949) 128.

Woodward, W.R. 24, 28, 34, 41.

Wulff, H.R. 5, 172, 175.

Wunderlich, C.A. (1815-1877) 21, 23 , $27,39-40,49,57,60-61,64$.

Wyss, D. 153.

Zwaardemaker, H. (1857-1930) 9091. 


\section{Curriculum vitae}

Ineke (Christine) Heerding is geboren op 3 februari 1954 te Amsterdam. Na haar eindexamen gymnasium $\beta$ aan het Murmellius Gymnasium te Alkmaar, studeerde zij van 1972 tot 1974 wiskunde en van 1974 tot 1981 filosofie aan de Universiteit van Amsterdam. Van 1983 tot 1987 werkte zij bij de Katholieke Universiteit Nijmegen als junior medewerker bij de vakgroep Wijsgerige antropologie van de Faculteit Wijsbegeerte aan een onderzoeksproject, dat werd gefinancierd door de Faculteit Geneeskunde.

Sinds 1986 is zij verbonden aan de faculteit Cultuurwetenschappen van de Open Universiteit Nederland, aanvankelijk als studiebegeleider, later als cursusteamleider en universitair docent. 
Colofon

Omslagontwerp

Studio Gonnissen en Widdershoven

Lay-out

Vivian Rompelberg

Uitgave

Datawyse, Maastricht

Uit deze uitgave mag zonder schriftelijke toestemming van de auteur niets worden verveelvoudigd en/of openbaar gemaakt door middel van druk, fotocopie, microfilm of anderszins, hetgeen ook van toepassing is op de gehele of gedeeltelijke bewerking.

No part of this publication may be reproduced in any form, by print, photoprint, microfilm or other means, included a complete or partial transcription, without the prior written permission of the publisher. 

Dit proefsehrift behandelt de geschiedenis van e genceskunde vanuit een fillosofische vraagstellig. Het betreft een analyse en een reconstructic vain concepten van de geneeskunde zoals ze van I84 tot 1970 in Nederland werden aangehangen. Da zijn achtereenvolgens de geneeskunde als natuuwetenschap, als levenswetenschap en als mensw. tenscbap. Tevens wordt een beschrijving gegeve! van de argumenten op grond warvan deze wetnschapsidealen of paradigma's destijds werden vededigd, verworpen of verlaten.

De discussies worden behandeld volgens een vas patroon. Ferst wordt een beknopte schets gegeva vain de formulering van de betreffende weten: schapsopvatting. Vervolgens wordt aandacht geschonken aan twee basisbegrippen die binnen clke gedachtebepaling omtrent de geneeskunde een essentiele rol spelen: ziektebegrip en klinisch oordeel. Tenslotte worden vooraianstaande medif uit de besproken perioden aan het woord gelater Ramaer, Donders, Winkler, Barge, Rumke en Querido.

Uit de beschrijving van de historische discussies over het wetenschappelijke karakter komit naar voren dat geneeskunde moet worden gerien als een voortdurend proces van argumentatie en discussie, In het streven naar een goede en wetenschappelijk gefundecrde geneeskunde - waarvan het oogmerk uitcindelijk altijd luidt: verantwoord handelen in de praktiijk - vindt men geen doorslaggevende bewijzen of 'eeuwige'warheden. Erkenning van deze feilbaarheid impliceert echter geen relativisme, maar houdt een aansporing in om voort te gaan met het kritisch onderzock van geldigheidsclaims binnen de geneeskunde.

Ineke Widdershoven-Heerding studeerde wijsbegeerte te Amsterdam. Zij is als universitair docent verbonden aan de Faculteit Cultuurwetenschappen van de Open Universiteit te Heerlen. 